\title{
FronTIERA ROMANĂ DIN DACIA INFERIOR. O TRECERE ÎN REVISTĂ ŞI O ACTUALIZARE. 1.
}

\author{
OVIDIU ȚENTEA, \\ FLORIAN MATEI-POPESCU, \\ VLAD CĂLINA
}

\section{REZUMAT:}

Această lucrare este un raport preliminar al celor mai recente rezultate ale cercetărilor pluridisciplinare efectuate în castrele de pe cursul mijlociu și inferior al Oltului, cuprinse între Hoghiz şi Dunăre, aşa-numitul limes Alutanus. Scopul acestei treceri în revistă este actualizarea informațiilor referitoare la aceste fortificații într-o manieră asemănătoare rapoartelor dedicate anumitor zone ale Imperiului Roman, publicate periodic în volumele congreselor internaționale dedicate studiului frontierelor romane. Cele mai recente rapoarte de sinteză pentru acest sector de frontieră romană au fost publicate în urmă cu peste două decenii în volumul Congresului Internațional al Frontierelor Romane de la Zalău, în 1997.

Intenția autorilor este ca prin acest raport să fie prezentate cele mai noi date obținute în cadrul Programului Național LIMES. Potrivit planului de acțiune al programului, identificarea monumentelor a fost realizată prin colectarea datelor pe teren prin periegheze, măsurători topografice și înregistrări prin zboruri cu drona (fotografii ortografice, oblice și filmări), coroborate apoi de informațiile disponibile în arhive la momentul respectiv. Cercetările s-au concentrat asupra fortificațiilor și a zonelor adiacente. Studiul efectuat încearcă să arate valorea acestor situri în vederea protejării şi valorificării lor durabile prin includerea în Lista Patrimoniului Mondial UNESCO.

\section{AbStract: Roman Frontier of Dacia InfERIOR. A REVIEW AND AN UPdate. 1.}

This paper is a preliminary report of the most recent results of multidisciplinary research carried out in the mid and lower Olt river forts between Hoghiz and the Danube, on the so-called limes Alutanus. The aim of this review is to update information about these fortifications, similarly to the reports dedicated to certain areas of the Roman Empire, published periodically in the volumes of international congresses concerning the study of the Roman frontiers. The last synthesis reports for this sector of the Roman frontier were published more than two decades ago in the volume of the International Congress on Roman Frontiers in Zalău in 1997.

It is the intention of the authors that this report presents the most recent data obtained in the framework of the National LIMES Programme. According to the programme's action plan, the monuments were identified by collecting field data through surveys, topographical measurements and drone flight recordings (orthographic photographs, oblique photographs and video recordings), which were then corroborated with the information available at that time in archives. Research has focused on the fortifications and adjacent areas. The study carried out attempts to show the value of these sites with a view to their protection and sustainable enhancement through inclusion in the UNESCO World Heritage List.

CUVINTE CHEIE: Perioadă romană, armata romană, Dacia Inferior, frontiere romane, fortificații

KEYWORDS: Roman Period, Roman Army, Dacia Inferior, Roman frontiers, fortifications.

\section{INTRODUCERE}

Cucerirea Daciei i se datorează lui Traian, dar menținerea ei între granițele Imperiului este opera împăratului Hadrianus.

Odată cu crearea unei provincii romane în zona vechiului regat al lui Decebal, Traian lăsase Muntenia sub supravegherea guvernatorului provinciei Moesia Inferior, ridicând doar castre auxiliare în anumite poziții cheie și construind o linie de apărare de-a lungul Oltului.

O parte a teritoriului nord-dunărean, mai precis acea parte care a format apoi provincia Dacia Inferior și cea mai mare parte a teritoriului Munteniei de astăzi, a rămas sub controlul armatei din Moesia Inferior, o parte însemnată 
dintre trupele auxiliare ale acestei provincii fiind dislocate la nordul Dunării. Cazul cel mai celebru este evident al cohortei I Hispanorum veterana, al cărei pridianum amintește că o parte din soldații acesteia se află la nordul Dunării, încă din septembrie 105. După moartea împăratului Traian ostilitățile au fost redeschise în zonă de către roxolani, dar situația conflictuală a fost reglementată prin pacea încheiată în primul an de domnie a lui Hadrianus. Acesta a reorganizat teritoriul de la nordul Dunării, creând două provincii, Dacia Superior și Dacia Inferior, probabil încă din anul 118 (Dacia Superior este atestată prima dată pe 19 noiembrie 119, iar Dacia Inferior pe 17 iulie 122, dar existența provinciei Dacia Superior implică și existența provinciei Dacia Inferior). După retragerea garnizoanelor romane din Muntenia, ca urmare a înțelegerilor cu roxolanii, s-a format o nouă provincie, Dacia Inferior. Armata acestei provincii, cu doar trei excepții (numerus equitum Illyricorum, numerus burgariorum et veredariorum și numerus Syrorum sagittariorum), a fost compusă din trupele auxiliare ale Moesiei Inferior detaşate la nordul Dunării încă din timpul expedițiilor dacice ale lui Traian. Puțin mai târziu, în anii 122/123 (prima dată atestată pe 14 aprilie 123), Hadrianus a desprins zona de Nord-Vest a provinciei Dacia Superior și a organizat o nouă provincie, Dacia Porolissensis.

Provincia Dacia Inferior cuprindea teritoriul dintre râurile Jiu și Olt, precum și Sud-Estul Transilvaniei. În fruntea provinciei se afla un procurator presidial, având în vedere faptul că în provincie staționau doar trupe auxiliare. Granița provinciei a fost stabilită de-a lungul Oltului, unde au fost construite castre de mici dimensiuni pe timpul lui Hadrianus și Antoninus Pius.

Organizarea administrativă a Daciei s-a schimbat în anul 168, când comandamentele militare ale celor trei Dacii (Dacia Superior, Inferior și Porolissensis) au fost reunite sub un legatus Augusti pro praetore trium Daciarum. Din acel moment sunt atestate și districtele finaciare Dacia Apulensis, Dacia Malvensis și Dacia Porolissensis. Suprapunerea teritorială dintre districtele militare și cele financiare nu este pe deplin dovedită, dar, în ceea ce privește Dacia Inferior și Dacia Malvensis, suntem de părere că în linii generale acestea se suprapun. De altfel, în secolul al III-lea, provincia apare doar cu numele Dacia Malvensis. Mari schimbări nu s-au produs pe granița provinciei Dacia Inferior, odată cu aceste reorganizări administrative, trupele atestate anterior continuând să ocupe aceleași castre, mai ales de-a lungul liniei defensive de pe râul Olt. Frontiera a fost apoi mutată spre Est la începutul domniei lui Septimius Severus, folosind vechiul drum militar din vremea lui Traian, care unea castrul legionar de la Novae şi colțul de Sud-Est al Transilvaniei, constituind aşa-numitul limes Transalutanus. Puternic lovită de atacul carpilor din anul 247, Dacia Inferior va fi pierdută, odată cu întreaga Dacie, abia pe vremea lui Gallienus.

Demersul nostru se dorește o trecere în revistă a stadiului cercetărilor frontierelor provinciei Dacia Inferior, structurată în două părți: castrele de pe cursul mijlociu și inferior al Oltului, (dintre Hoghiz și Dunăre), denumit de Gr. Tocilescu limes Alutanus (Tocilescu 1900, 120), vor fi prezentate în prima parte, iar castrele de pe linia transalutană vor fi incluse într-un raport care va fi publicat într-un număr viitor al revistei.

\title{
CATALOGUL FORTIFICAȚIILOR*
}

\author{
1. Hoghiz \\ jud. Braşov (RAN: 41186.01; BV-I-m-A-11280.02)
}

Castrul de la Hoghiz (fig. 1.1 - 1.11) este cel mai mare castru auxiliar din zona estică a Daciei. Acesta era un punct strategic de primă importanță, fiind punctul de trecere peste Olt, fiind amplasat pe malul stâng al râului, spre deosebire de cele învecinate din aval. Descoperirea recentă a castrului de la Ungra (fig. 2.1, 2.2) are menirea de a sublinia importanța strategică a acestei zone.

Fortificația a fost construită pe o terasă înaltă, din stânga Oltului, situată în apropierea zonei de confluență a Homoroadelor cu Oltul, în punctul numit „La Cetate”. Situl este localizat la aproximativ doi km Vest de satul Hoghiz, în dreptul satului Ungra, situat pe malul opus al râului (fig. 1.1).

Aici au staţionat în garnizoană de-a lungul timpului mai multe trupe: ala Asturum (CIL III 8074, 1b= IDR III 4, 242 - material tegular ștampilat), cohors III Gallorum (IDR III 4, 231 = AE 1944, 42 - datare 177-180; CIL III 955 = CIL III 7721 = IDR III 4, 235) și numerus Illyricorum (AE 1977, 711 = IDR III 4, 243 - material tegular ştampilat). Castrul se distinge la suprafață ca un patrulater conturat de urmele valurilor de pământ.

\footnotetext{
Pentru o parcurgere cât mai fluentă a textului am grupat referințele bibliografice la finalul prezentării fiecărei fortificații, inserând doar citările esențiale în text, în interiorul parantezelor. Bibliografia a fost grupată, de asemenea, la finalul fiecărei prezentări. Abrevierile se regăsesc la finalul articolului.
} 
În cursul săpăturilor arheologice (K. Horedt - 1949, D. Protase - 1965 - 1967; 1975-1979, respectiv L. Petculescu - 1989), au fost documentate două faze de construcție. Castrul de lemn și pământ avea plan dreptunghiular cu dimensiuni neprecizate, palisada fiind realizată din două paramente (Protase 1977b, 197). Valul aplatizat, consemnat cu lățimea de $11 \mathrm{~m}$ și înălțimi variabile, până la $2 \mathrm{~m}$, îngloba două rânduri de palisade, fiind dublat în exterior de un șanț de apărare cu o deschidere de $4 \mathrm{~m}$ și adâncime de $1 \mathrm{~m}$ Construirea acestuia s-a făcut în primii ani ai secolului II p. Chr. Castrul de pământ (cel puțin o porțiune a incintei - s.n.) a fost incendiat potrivit informațiilor obținute din cercetările arheologice efectuate de K. Horedt (Horedt 1953, 788). În zona centrală a fortificației sunt vizibile urmele săpăturilor arheologice neacoperite cu pământ. Pe această suprafaţă nu am putut efectua măsurători geofizice. Urme ale intervențiilor arheologice se disting pe și pe latura Nord-Estică, porțiune unde se pot observa și astăzi câteva blocuri masive de piatră dispuse pe două asize.

Castrul de piatră avea un plan aproximativ dreptunghiular cu colțurile rotunjite, cu dimensiunile medii de $220 \times$ 165 m. Incinta a fost construită din două paramente de piatră cu grosimi de $1,15 \mathrm{~m}$ (exterior), respectiv $1,05 \mathrm{~m}$ (interior). Incinta dublă a fost întărită cu ziduri transversale, groase de aproximativ $0,90 \mathrm{~m}$, dispuse la intervale de aproximativ $2,80 \mathrm{~m}$. Nu au fost identificate structuri de rezistență distincte pentru turnurile de colț, acestea fiind preluate de compartimentările regulate care întăreau incinta (fig. 1.3). Au fost săpate porțile de pe laturile de Sud și Est, documentându-se turnuri dreptunghiulare $(5,50 \times 7 \mathrm{~m})$, cu o deschidere a porții de 5,50 $\mathrm{m}$. În interior au fost documentate ziduri din clădirea comandamentului (principia) și probabil din praetorium, în zona unde K. Horedt ar fi identificat o baie (Horedt et al. 1950, 124).

Legătura dintre castrele de la Hoghiz, Brețcu și Drajna pe baza tehnicii de construcție, toate trei fiind prevăzute cu un zid dublu, precum și enunțarea contemporaneității lor a fost argumentată de D. Protase (1977). Ioana BogdanCătăniciu considera că acestea au fost construite probabil de legiunea XI Claudia (Cătăniciu 1981, 10). Totuşi castrul de la Hoghiz a fost construit de un detaşament al legiunii XIII Gemina.

Ca urmare a prelucrării cartărilor efectuate din dronă (DTM și hillshade - fig. 1.7/1.8) se observă faptul că planul castrului corespunde în linii mari primului plan publicat în anul 1950 (Horedt et al. 1950, 124). Planul publicat 3 ani mai târziu a fost ușor ajustat, având forma unui dreptunghi (Horedt 1953, 789, fig. 2 - 1.3). Dimensiunile acestuia sunt $220 \times 165 \mathrm{~m}$ (fig. 1.3).

Planul rezultat din prospecțiunile geofizice (Țentea și Popa 2017) indică micile neregularități semnalate în prima campanie de săpături, aducând în plus unele elemente orientative privind organizarea internă a castrului. Clădirile nu se disting cu precizie, dar se pot observa grupările și orientările barăcilor din praetentura și din retentura. În latera praetorii se observă o clădire mare în partea sudică, care pare a fi praetorium. Nu se pot distinge alte amănunte din cauza săpăturilor extinse efectuate în principia și rămase încă neacoperite (fig. 1.4).

Construirea castrului în piatră de către un detaşament al legiunii XIII Gemina de la Apulum (Dacia Superior) a avut loc în timpul procuratorul Ti. Claudius Constans, între anii 130-132 (Piso 2000, 235 - reinterpretarea inscripției CIL III 935 = IDR III 4, 230 = ILD 431 = AE 2000, 1258 = Piso 2013, 135, nr. 5; despre datarea prezenței lui Ti. Claudius Constans în Dacia Inferior vezi Piso 2013, 134-140, nr. 82). Posibilitatea ca inscripția în cauză să provină de la un monument onorific (Opreanu 2003, 319) este foarte mică având în vedere dimensiunile considerabile. Din păcate, contextul exact al trimiterii acestui detaşament al legiunii la Hoghiz nu se cunoaște. Fiind însă singura legiune din cele trei provincii dacice, este foarte probabil că detaşamente vor fi fost trimise în provinciile Dacia Porolissensis și Dacia Inferior mai ales pentru a ajuta la construirea fortificațiilor auxiliare de piatră.

Așezarea civilă a lăsat urme de jur-împrejurul castrului. Cele mai importante clădiri au putut fi identificate în zona vestică și nordică a castrului. La aproximativ $120 \mathrm{~m}$ Nord-Vest de colțul vestic al fortificației, a fost identificată o clădire rectangulară $(50 \times 50$ m), care are caracteristicile unor băi (balneum) de tip circular (Țentea și Popa 2017, $140,1.4 a)$.

Bibliografie: Christescu 1937, 43, 51, 61, 131, 178, 187; Horedt, K. et al. 1950, 123-130; Horedt, K. 1953. Cercetările arheologice din regiunea Hoghiz-Ugra și Teiuş. Materiale şi cercetări arheologice 1: 785 815; Protase, D. 1977. Castre romane cu dublu zid de incintă descoperite în Dacia. Sargetia 13, 191-202 = Protase, D. 1977. Römische Lager mit doppelten Umfassungsmauern in Dakien. in: J. Fitz (ed.) Limes. Akten des XI. Internationalen Limeskongresses. Budapest: Akadémiai Kiadó: 303-320; Vlădescu 1983, 116, nr. 24; Vlădescu 1986, 81-91; Gudea 1997, 66-67, nr. 43; Gudea 2005, 497-498, nr. VII. B. 9; Marcu 2009, 207-212, nr. 54; Țentea, O. şi Popa, Al. 2017. Castrul și băile romane de la Hoghiz - Rezultatele recente ale prospecțiunilor geofizice, Cercetări Arheologice 24: 137-143. 


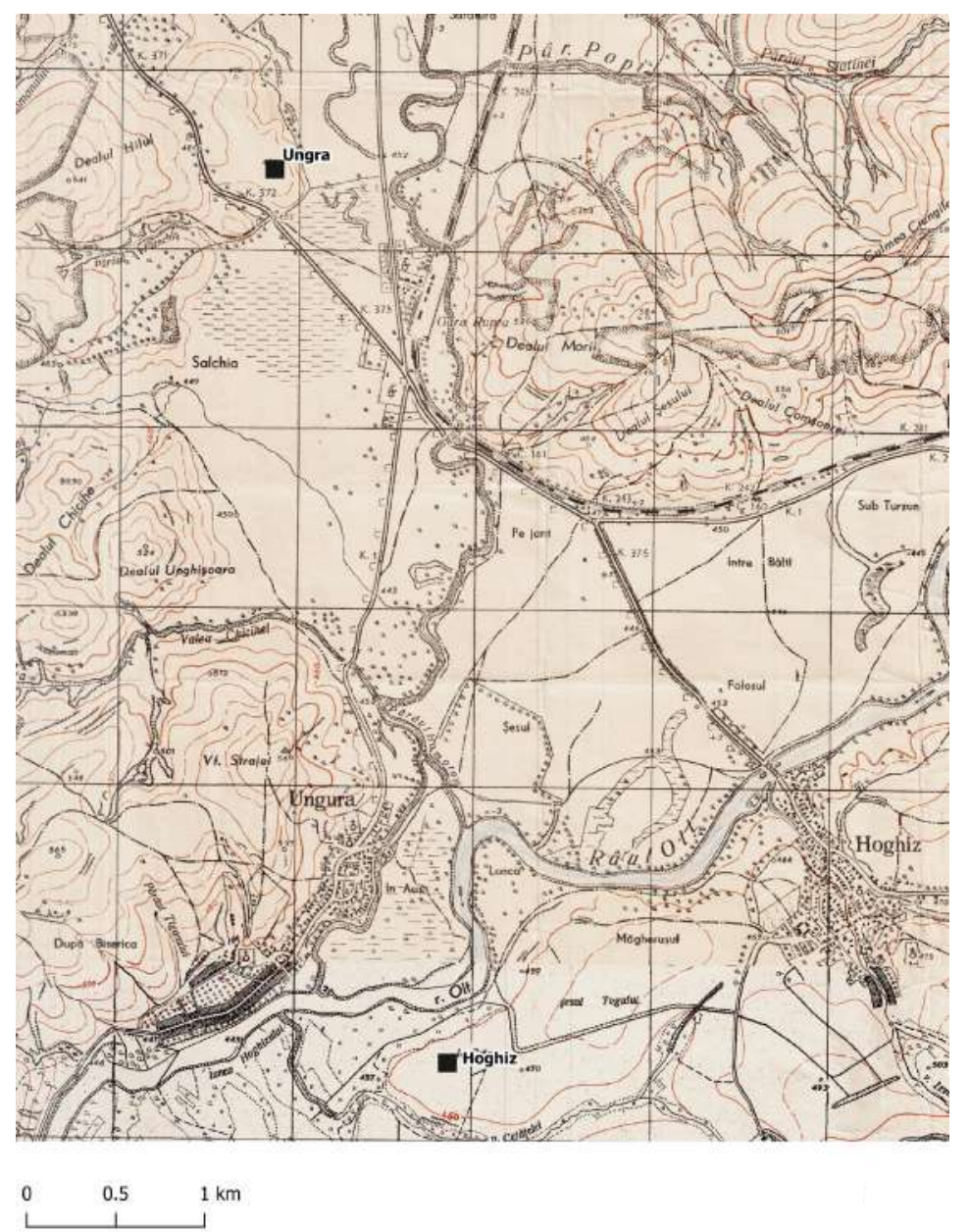

1.1. Localizarea castrelor de la Hoghiz și Ungra pe Planurile directoare de tragere.
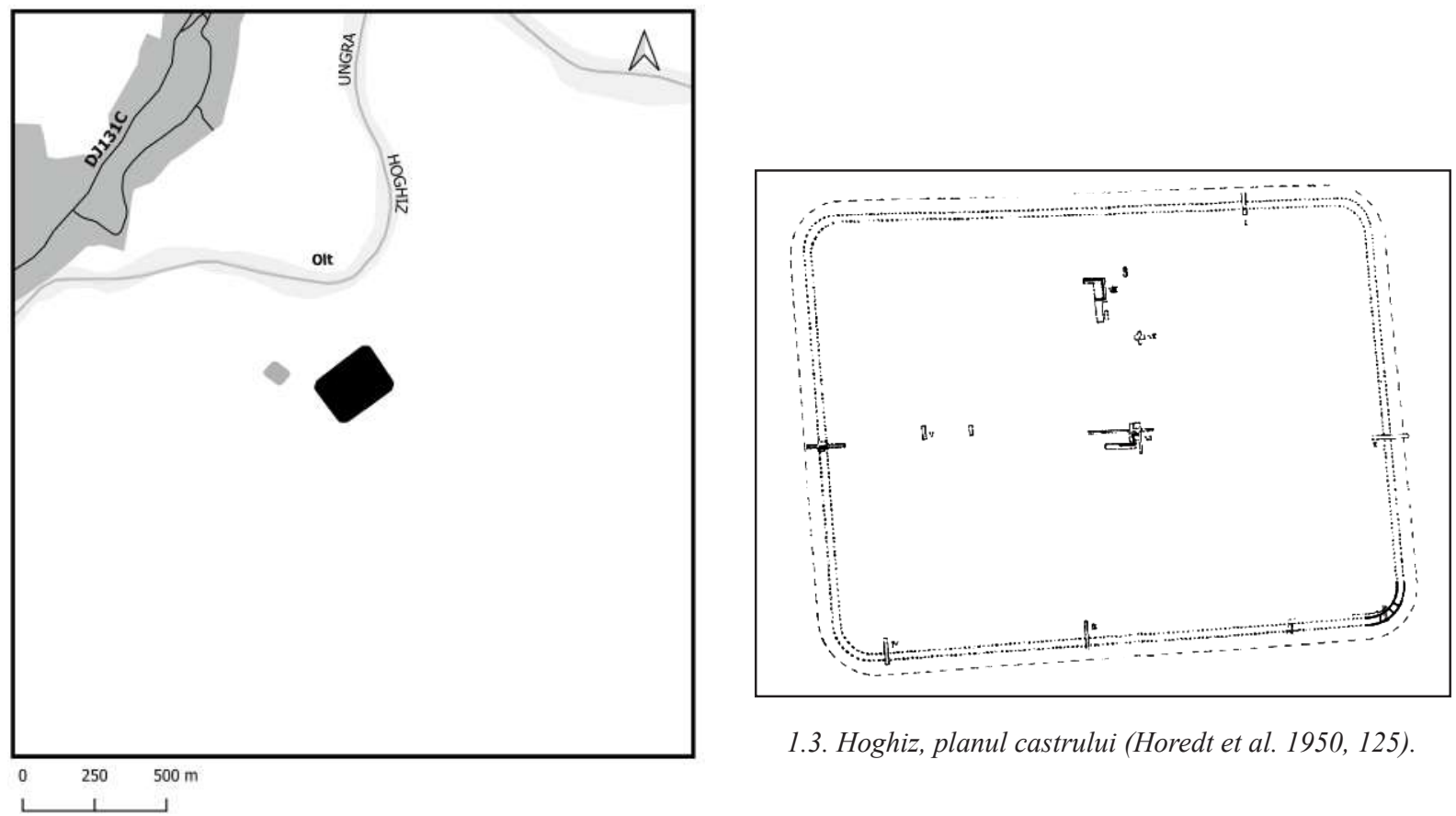

1.3. Hoghiz, planul castrului (Horedt et al. 1950, 125).

1.2. Hoghiz, localizarea castrului și a băilor. 


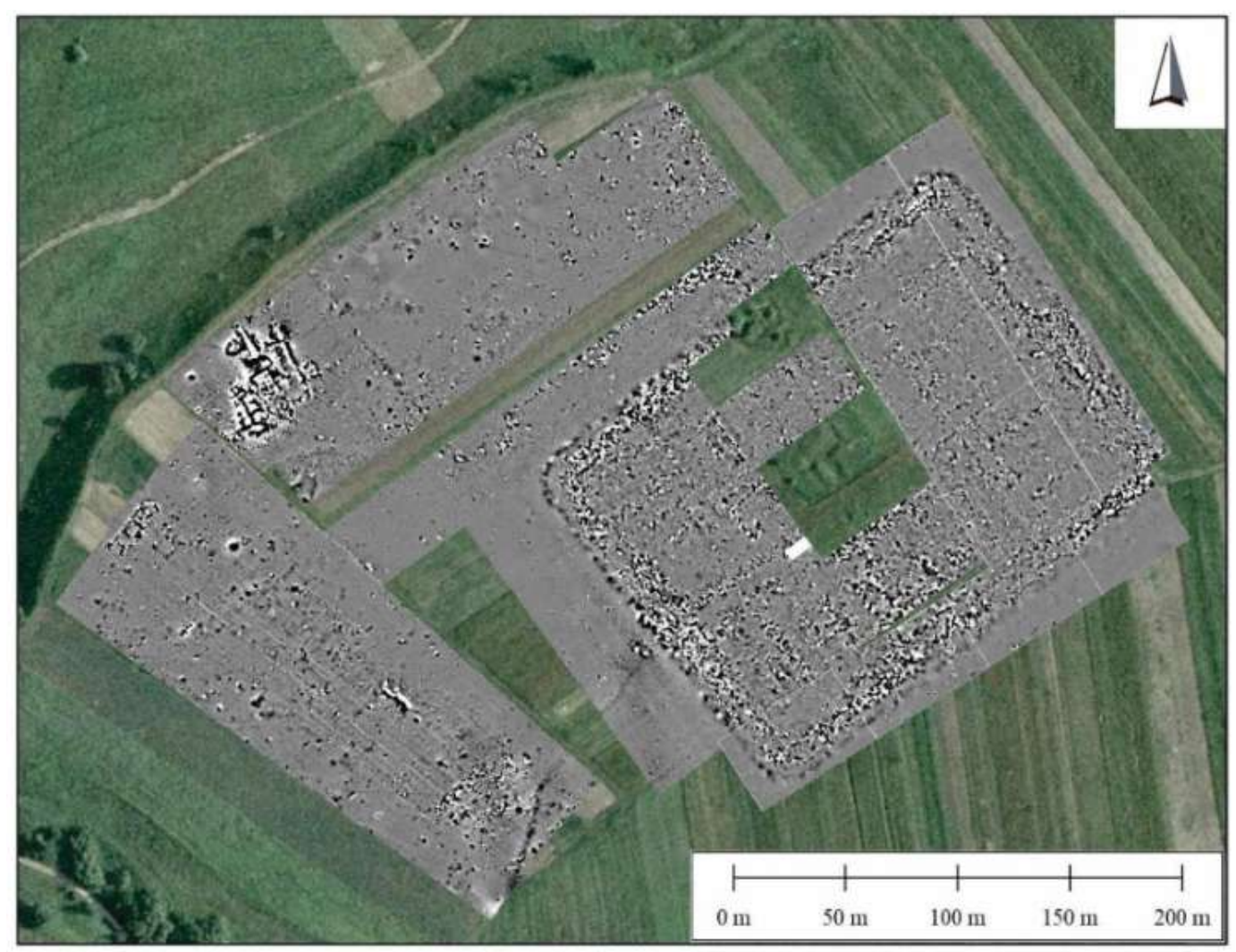

1.4. Hoghiz, planul prospecțiunilor geofizice efectuate in castru și parțial în așezarea civilă (Tientea, Popa 2018, 140, fig. 5).

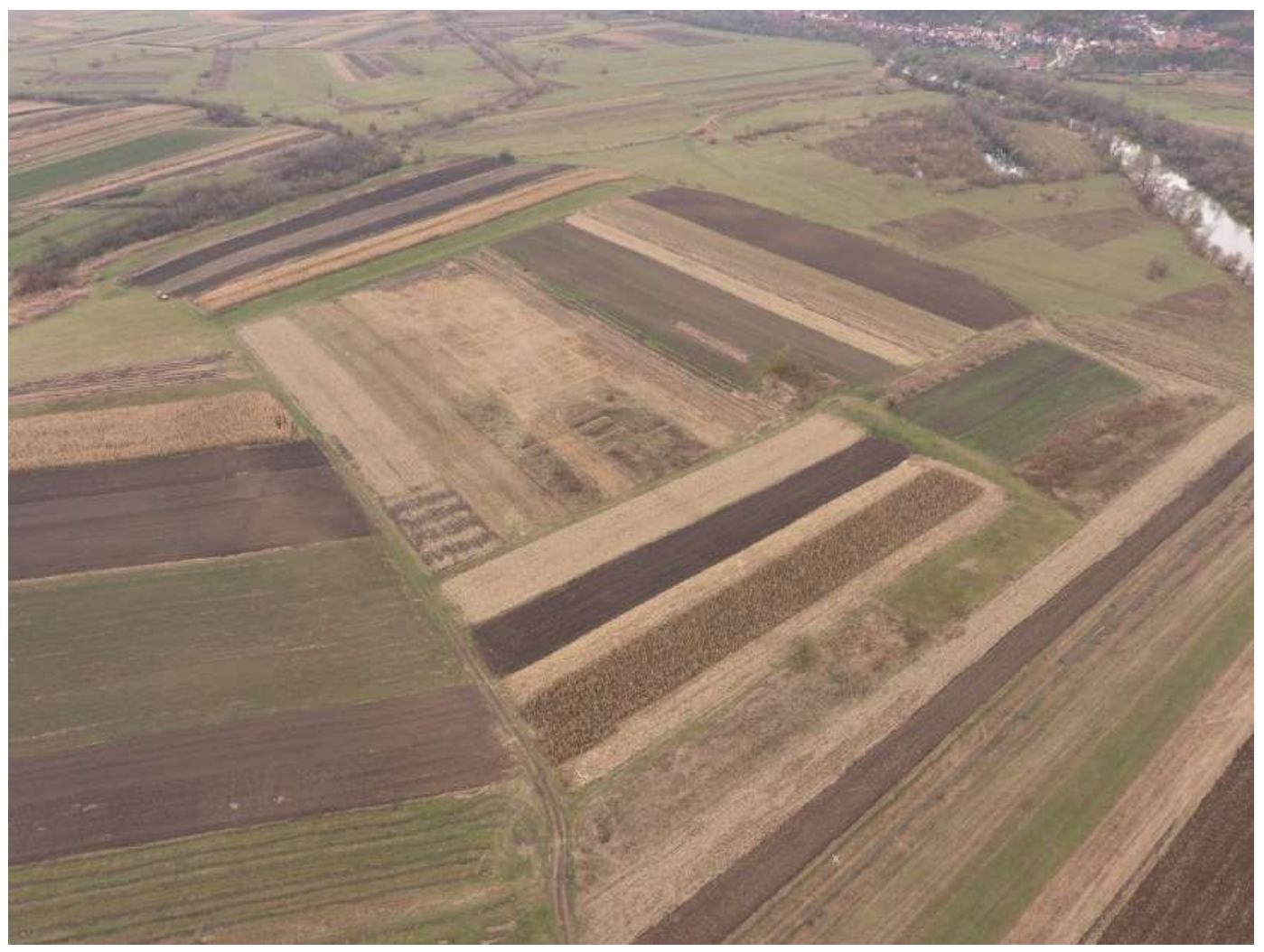

1.5. Hoghiz, fotografie oblică din dronă, vedere dinspre Sud-Vest (noiembrie 2016). 


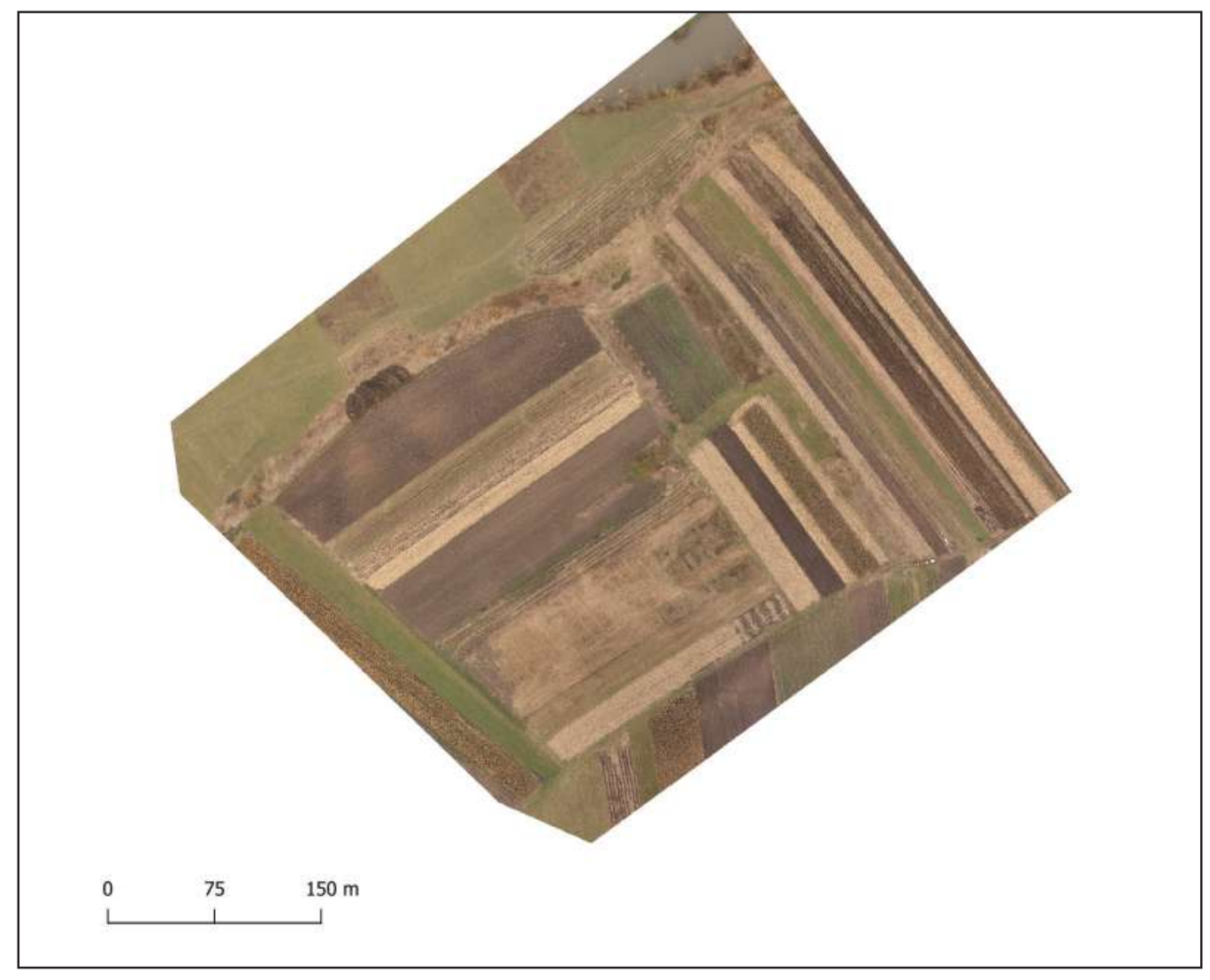

1.6. Hoghiz, ortofotoplan dronă.

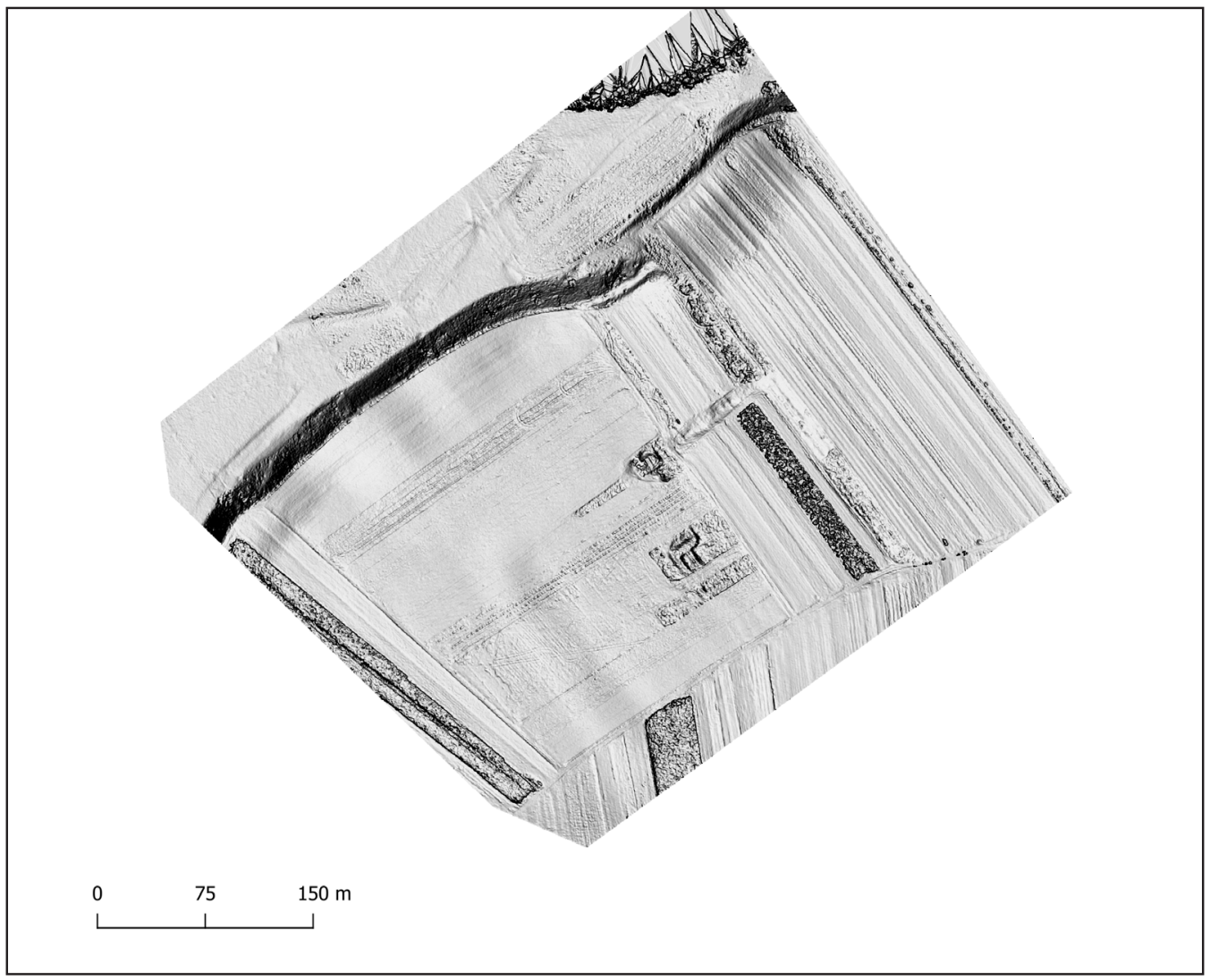

1.7. Hoghiz, model digital umbrit (hillshade). 


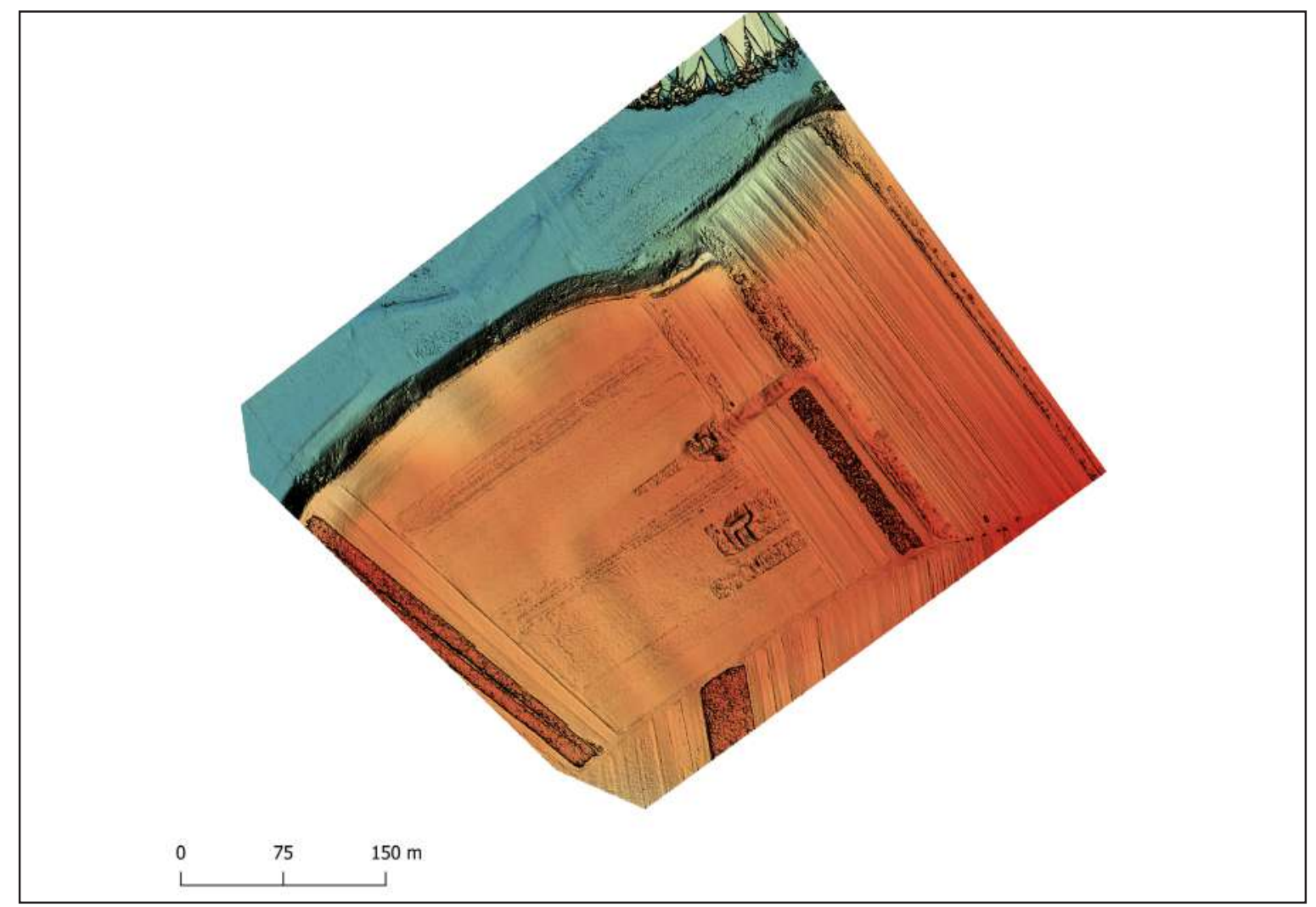

1.8. Hoghiz, model digital al terenului.

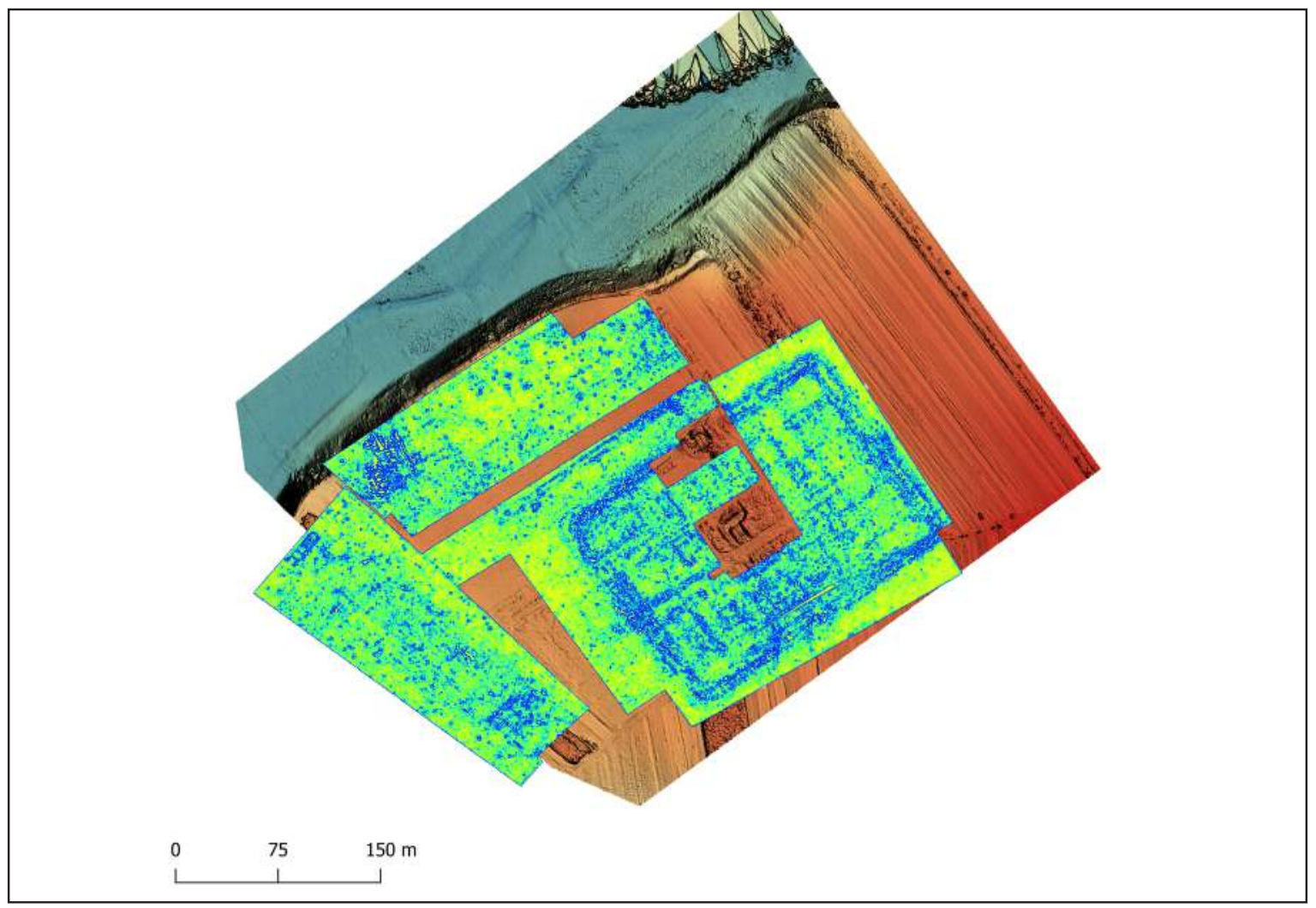

1.9. Hoghiz, planul prospecțiunilor geofizice efectuate în castru și parțial în așezarea civilă suprapus pe modelul digital al terenului. 


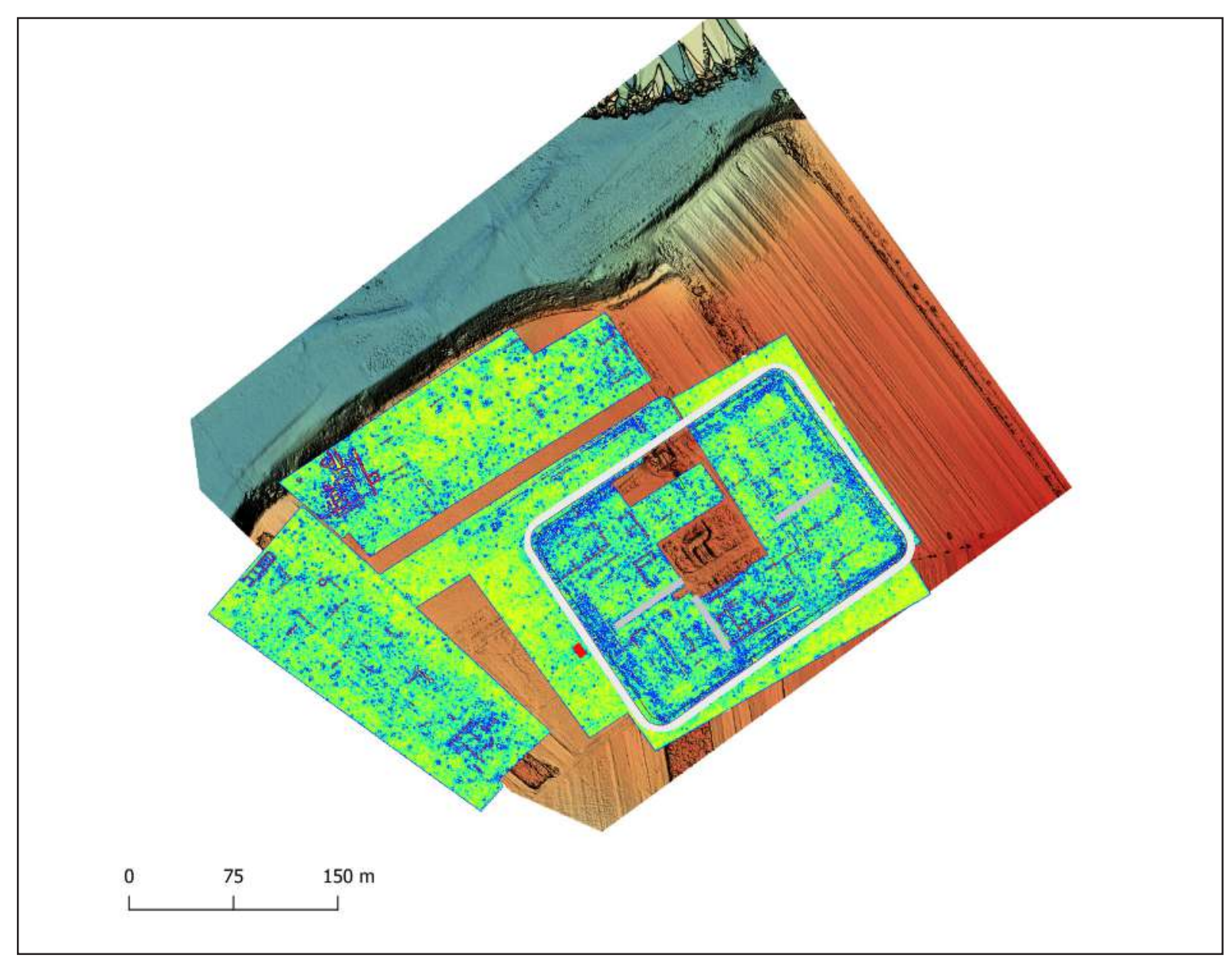

1.10. Hoghiz, reconstituirea planului suprapus pe modelul digital al terenului.

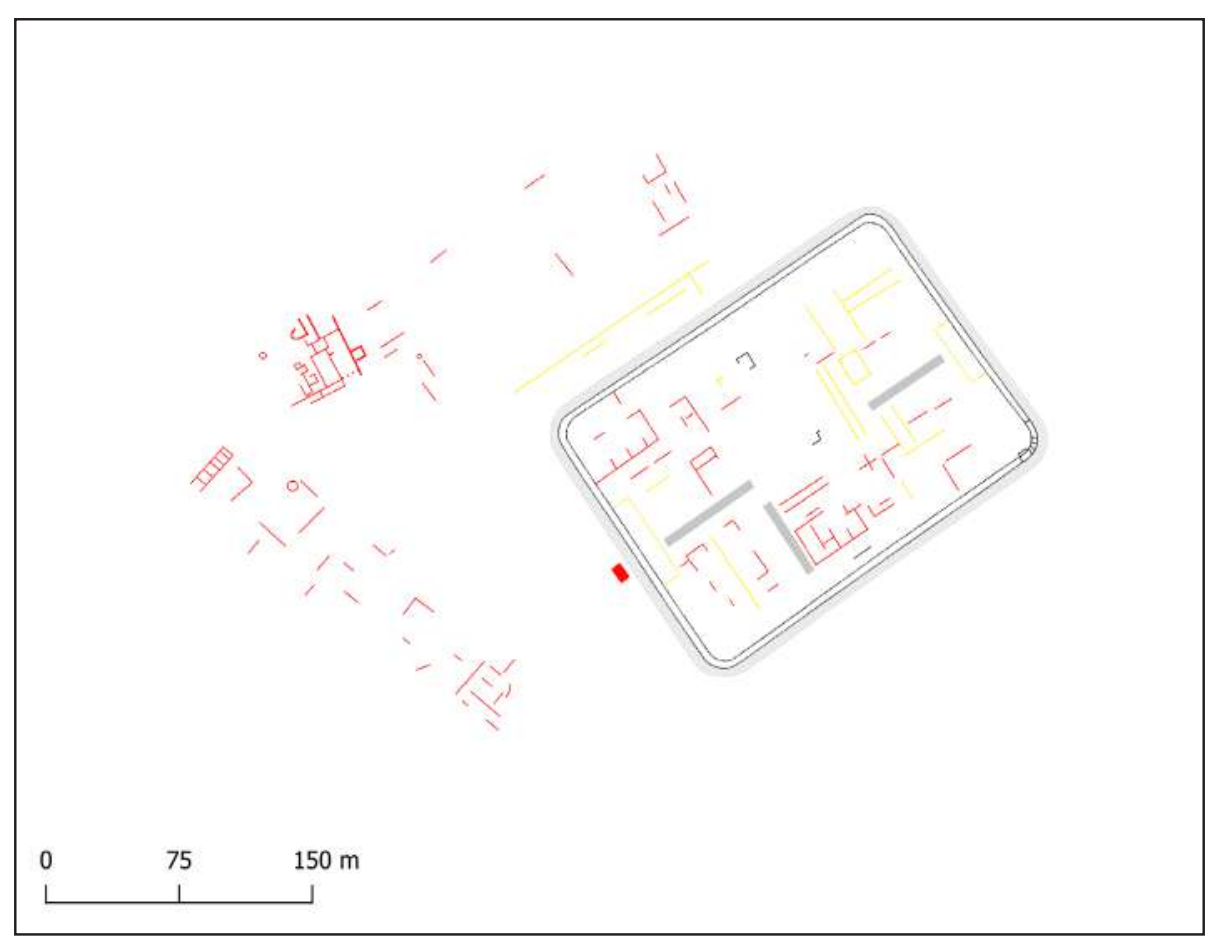

1.11. Hoghiz, reconstituirea planului castrului și așezării civile. 


\section{Ungra}

jud. Braşov (RAN: 42165.08)

Castrul (fig. 2.1 - fig. 2.4) este amplasat pe terasa înaltă a râului Homorod, situată la dreapta Oltului, în punctul numit „Pe Hill”, la cca $5 \mathrm{~km}$ distanță față de castrul roman de la Hoghiz (Fig. 2.1 / 2.2).

Fortificația a fost identificată recent, fiind publicat un prim studiu cuprinzând rezultatele cercetărilor pluridisciplinare, verificate printr-o săpătură arheologică în cursul anului 2018.

Castrul se distinge cel mai bine pe fotografiile din satelit - Corona 1968 (fig.2.2). Între timp, suprafaţa respectivă a fost destul de afectată de lucrările agricole. Semnalarea sa a fost făcută în urma recunoașterilor pe teren. În cursul anului 2018, a fost efectuată o săpătură de control pe incinta nordică, în apropierea colțului nord-vestic. A fost identificată o fossa dublă, în formă literei „W”, precum și incinta dublă de lemn a castrului cu lățimea de 2 metri. Dimensiunile fortificației sunt de $110 \times 130 \mathrm{~m}$.

Atestarea acestui castru cu palisadă de lemn este foarte importantă în contextul studierii strategiei defensive în acest areal, în care se asigura traversarea Oltului, și unde era situată granița dintre provinciile Dacia Inferior și Dacia Superior.

Bibliografie: Gridan, S., Urdea, P. şi Hegyi, Al. Castrul de la Ungra, jud. Brașov. Cercetări Multidisciplinare, în: $\mathrm{S}$. Forțiu ed. In Honorem Doina Benea, Interdisciplinaritate in Arheologie și Istorie, Timişoara, 25 noiembrie 2017 Vol.2: Metode Interdisciplinare şi Istorie: 851-883. Szeged: JATEPress Kiadó; Gridan, S., Hegyi, Al. şi Zăgreanu, R. Castrul Ungra - Rupea 6 (jud. Braşov) - cercetări invasive, Campania 2018, Prezentare la Simpozionul internațional „ArheoVestInterdisciplinaritate $\quad \hat{n}$ Arheologie". Ediția a VI-a, In Memoriam Marian Gumă (1951-1998).

https://www.academia. e du/40224081/2018 Castrul_Ungra_Rupea_6_ jud_B ra $\%$ C $5 \% 9 \mathrm{Fov}_{-}$ cercet\%C4\%83ri_invazive_ prezentare_Simpozion Interna $\%$ C $5 \%$ A 3 ional Arheovest_VI_24_11_2018.
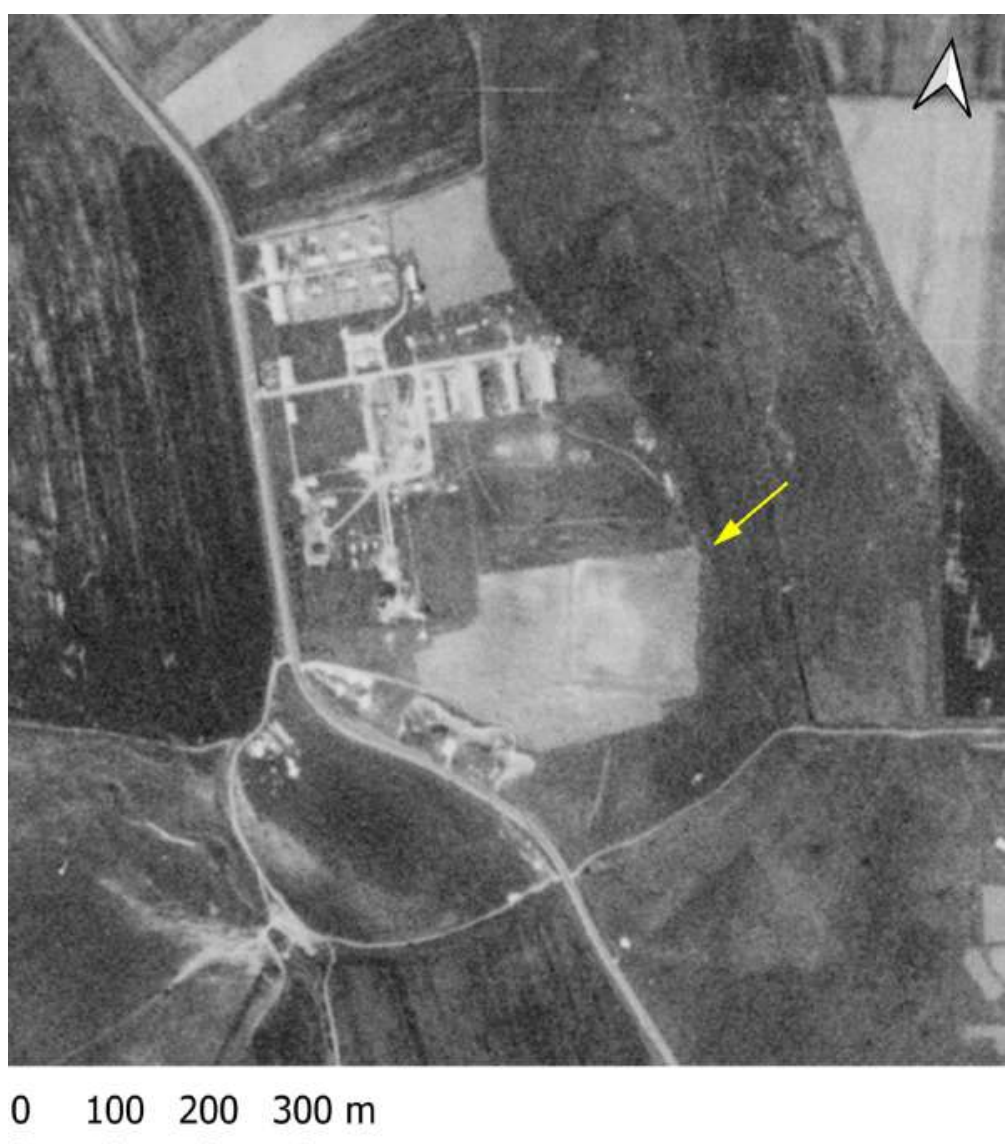

2.2. Ungra, localizarea castrului, poză declasificată satelit Corona 1968 (U.S. Geological Survey, 2008). 


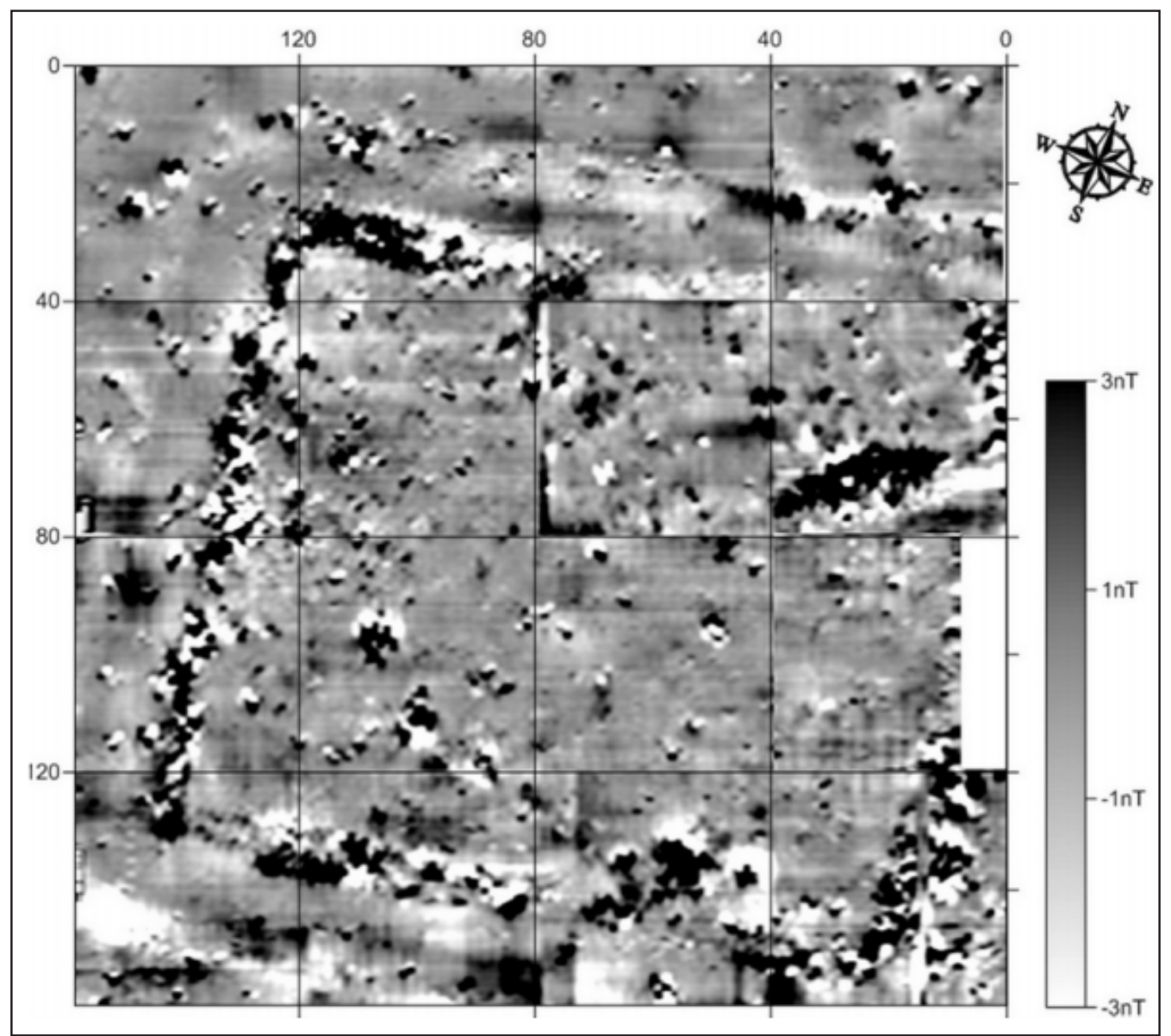

2.3. Ungra, planul prospecțiunilor geofizice efectuate în castru (Gridan et al. 2017, 856, fig. 3).

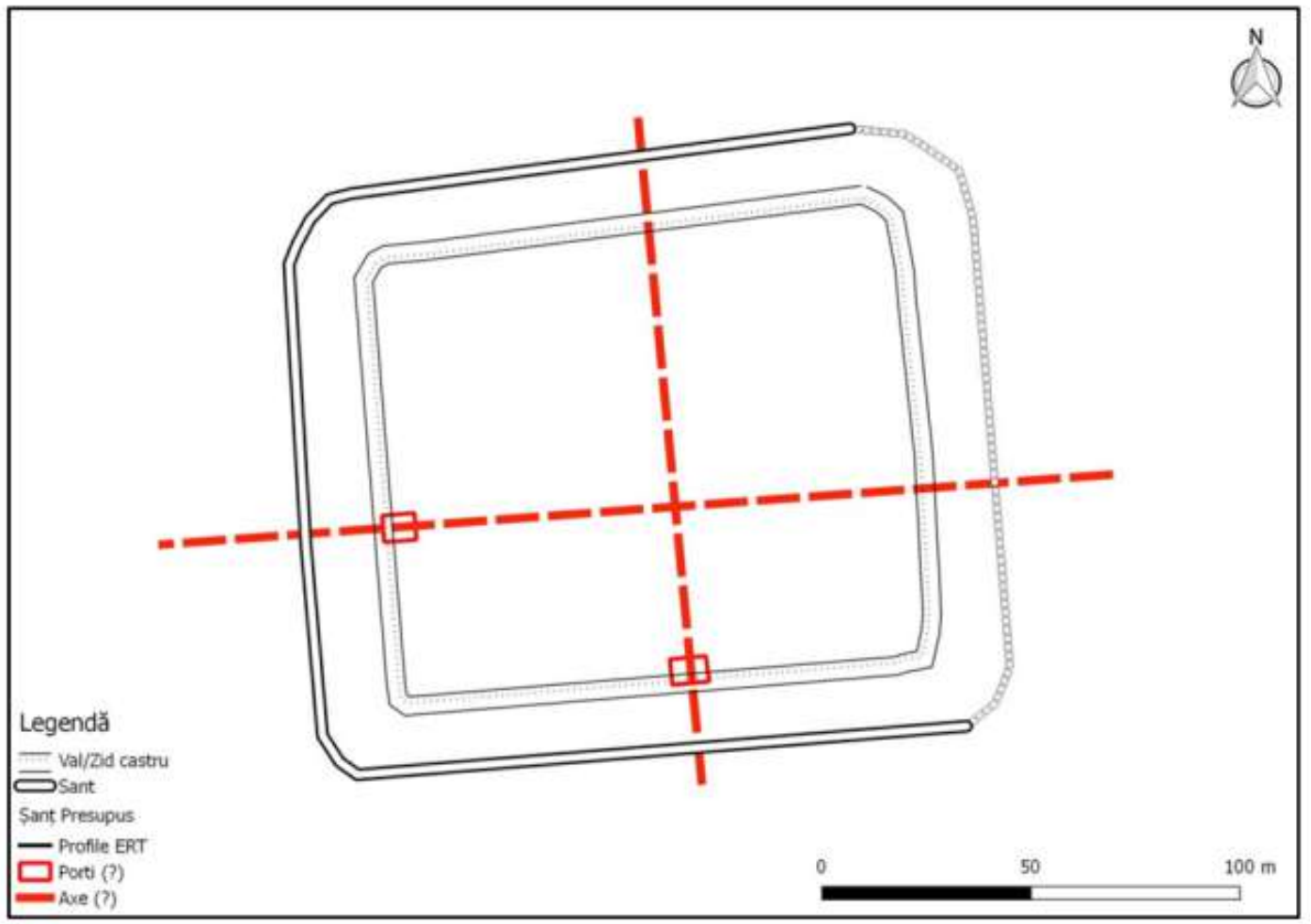

2.4. Ungra, planul castrului (Gridan, S., Urdea, P. și Hegyi, Al. 2017, 861, fig. 9). 


\section{Cincşor}

Com. Voila, jud. Braşov (RAN: 42325.01; BV-I-m-A-11266.01)

Castrul (fig. 3.1 - 3.8) se situează la aproximativ patru km Est de satul actual, pe malul drept al Oltului, în punctul Burgstadt/Grădişte. Urmele sale nu mai sunt vizibile la suprafață, motiv pentru care a fost identificat în urma a numeroase săpături derulate de-a lungul timpului (săpături I. Pop 1974 - 1975; I. Pop, L. Petculescu - câteva campanii între 1980 şi 1989, D. Isac 1992). Castrul a fost distrus în cea mai mare parte de eroziunile solului. Sondajele efectuate au avut ca principal obiectiv identificarea limitelor castrului şi a elementelor sistemului defensiv. În urma corelării informațiilor acumulate de-a lungul timpului şi a extinderii unei secțiuni anterioare, a putut fi reconstituit colțul sud-vestic al acestei fortificații (fig. 3.4), argumentându-se existența unui castru de lemn și pământ, înlocuit de unul cu incinta din piatră, de plan dreptunghiular, cu dimensiuni neprecizate. În interior au putut fi identificate amprentele unor pereți dintr-o constructie de lemn.

Staţionarea cohortei II Flavia Bessorum în acest castru a fost documentată prin descoperirea unor ștampile (IDR III 4, 181; ILD 426) şi a unei inscripții de pe un monument funerar ridicat de un prefect al acestei trupe

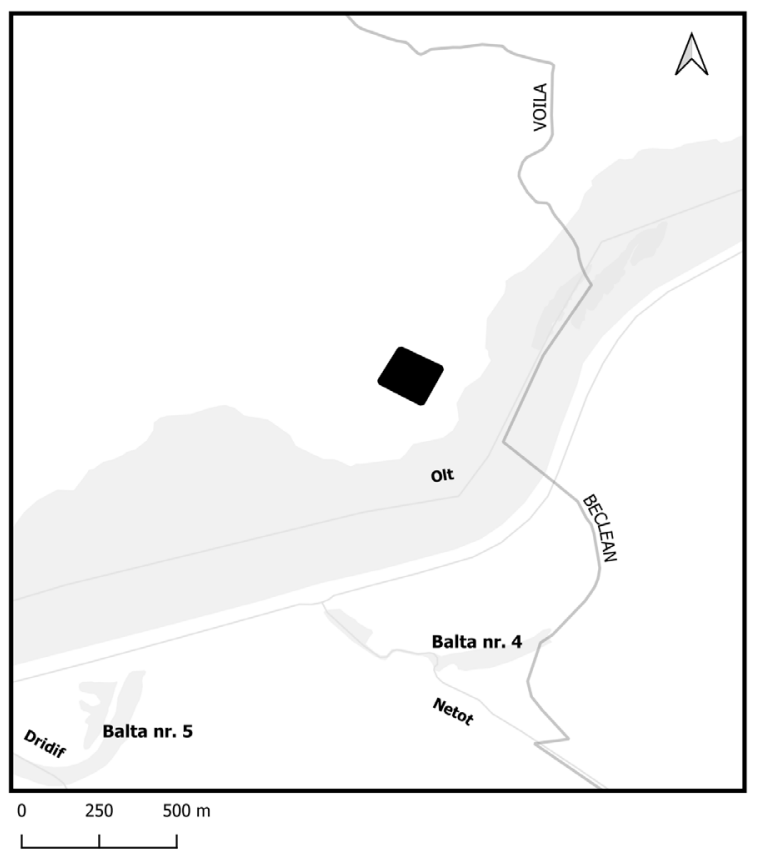

3.1. Cincșor, localizarea castrului. (IDR III 4, 179). În apropierea amenajării cursului râului Olt, în anul 1986 a fost descoperită o mască de bronz, parte a unui coif (Gesichtshelm), folosit în aşa numitele hippika gymnasia.

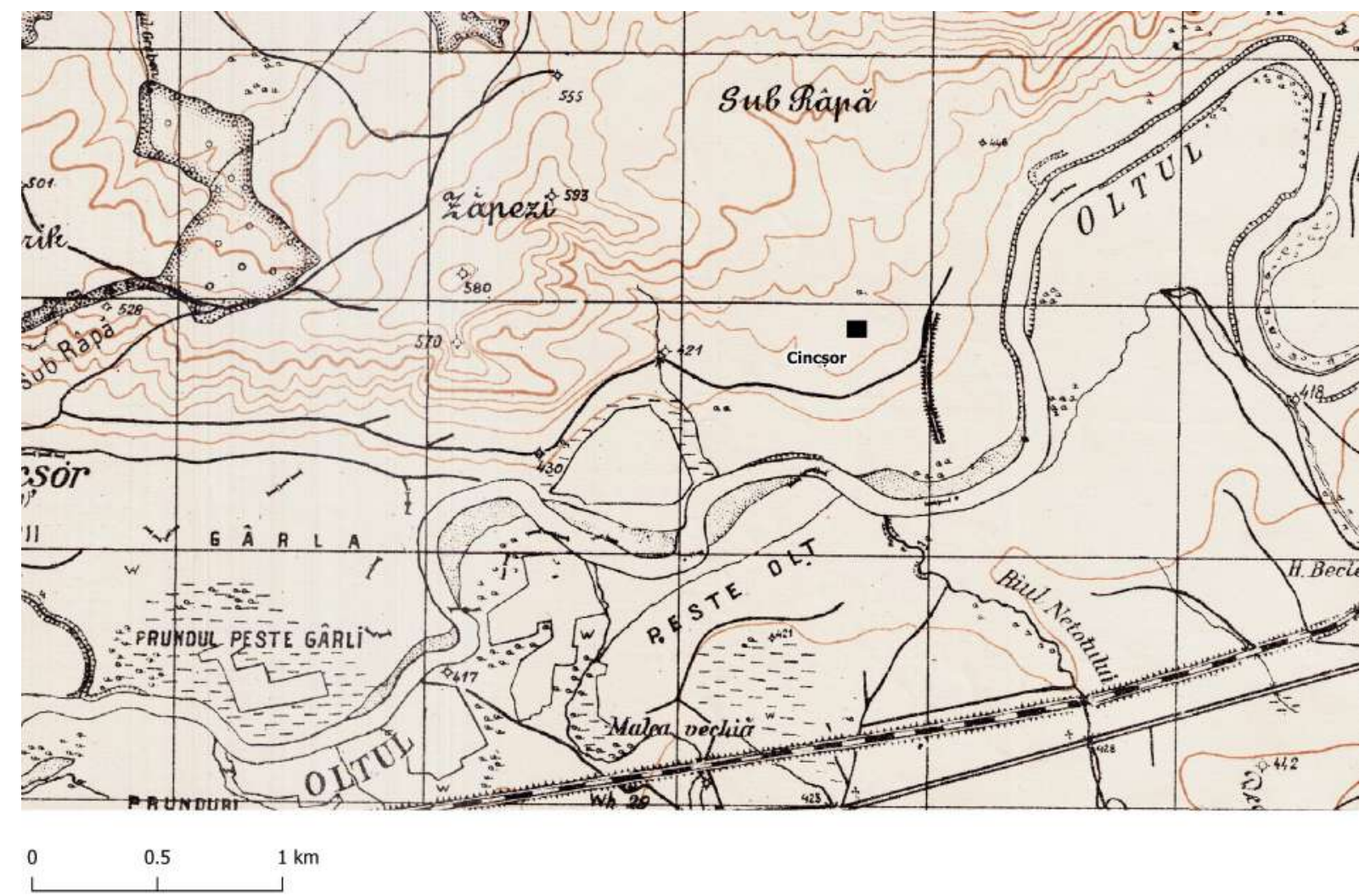

3.2. Cincşor, localizarea castrului pe Planurile directoare de tragere. 


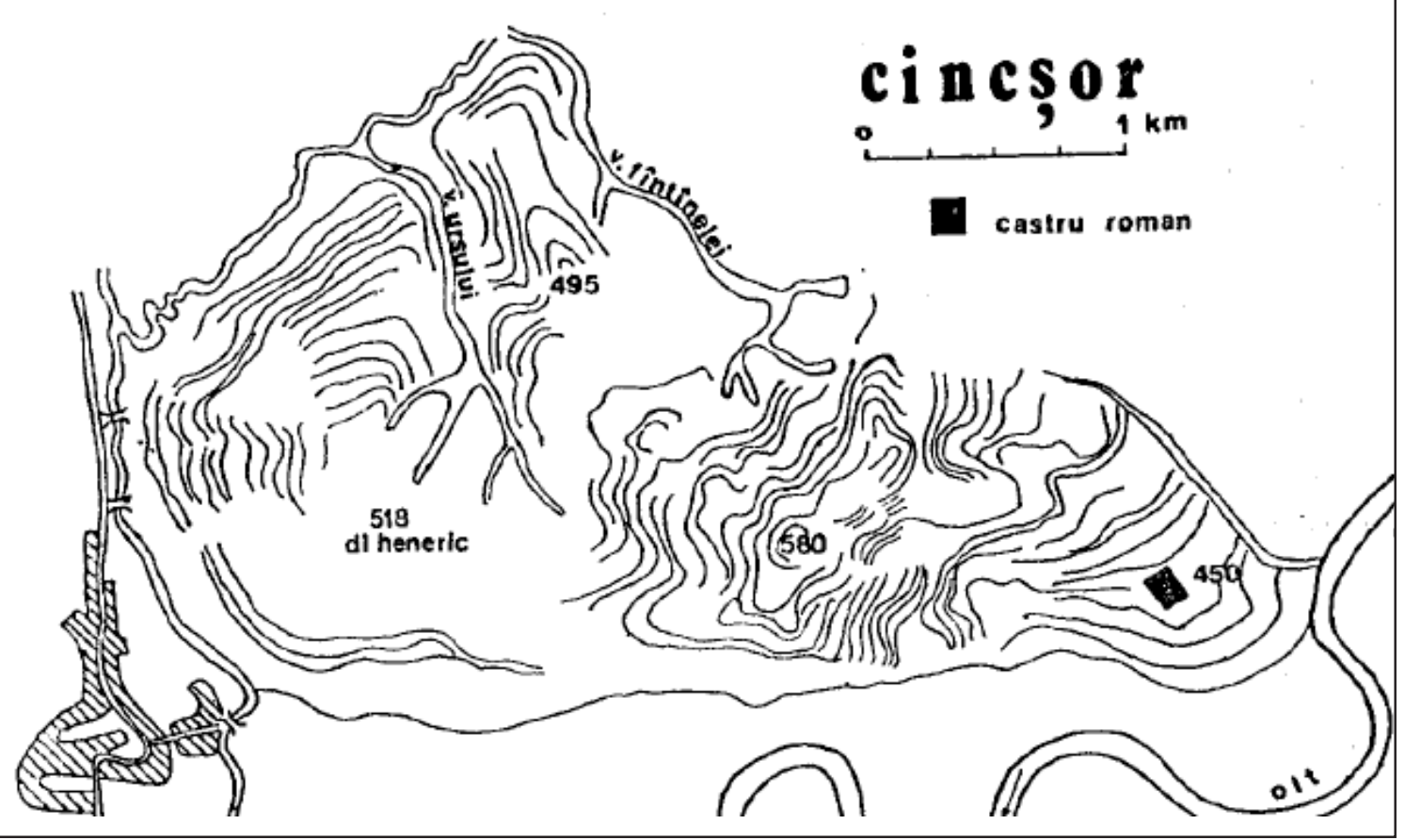

3.3. Cincşor, localizarea castrului (Isac, Isac 1994, 103, fig. 1).

La suprafață se disting urmele unor secțiuni arheologice, acoperite în cea mai mare parte cu pământ (fig. 3.5 și 3.6). Prin corelarea informațiilor cartografice cu cele cunoscute din publicații și de pe teren, precum și modelul digital al terenului, obținut prin achiziția datelor cu drona, am putut obține unele scenarii privind forma castrului (fig. 3.7). Cea mai probabilă variantă ne oferă un contur rectangular al fortificației, cu laturile de $130 \mathrm{~m}$ (sudică) $\times 110 \mathrm{~m}$ (vestică) (fig. 3.8). Ne propunem ca pe viitor să obținem informații suplimentare relevante prin prospecțiuni geofizice.

Bibliografie: Christescu 1937, 44, 51, 61, 183; Tudor 1968, 281; TIR L 35, 32; Vlădescu 1983, 115, nr. 23; Pop, I. I. 1983. Atestări recente ale cohortei II Flavia Bessorum la Cincşor, Cumidava 13, 2: 43-46; Vlădescu 1986, 81; Dragotă, Gh. 1987: Masca romană de bronz de la Cincşor (jud. Braşov), Studii şi cercetări de istorie veche și arheologie 38, 3: 276-280; Isac D. şi Isac A. 1994. Noi date arheologice despre castrul roman de la Cincşor (jud. Braşov), Ephemeris Napocensis 4: 103112; Gudea 1997, 67-68, nr. 44; Gudea 2005, 497, nr. VII. B.8; Marcu 2009, 202-203, nr. 54.

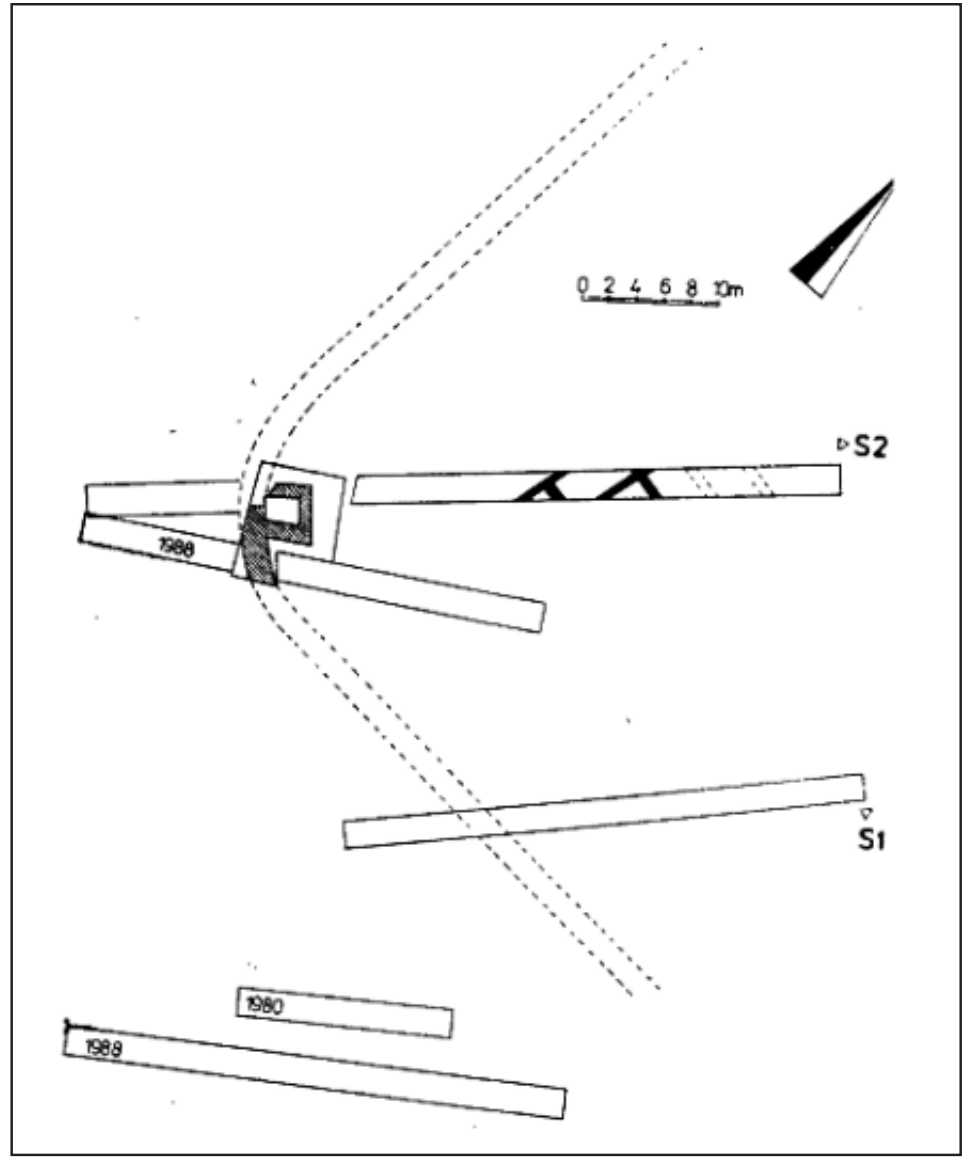

3.4. Cincşor, planul castrului (Isac, Isac 1994, 105, fig. 2). 


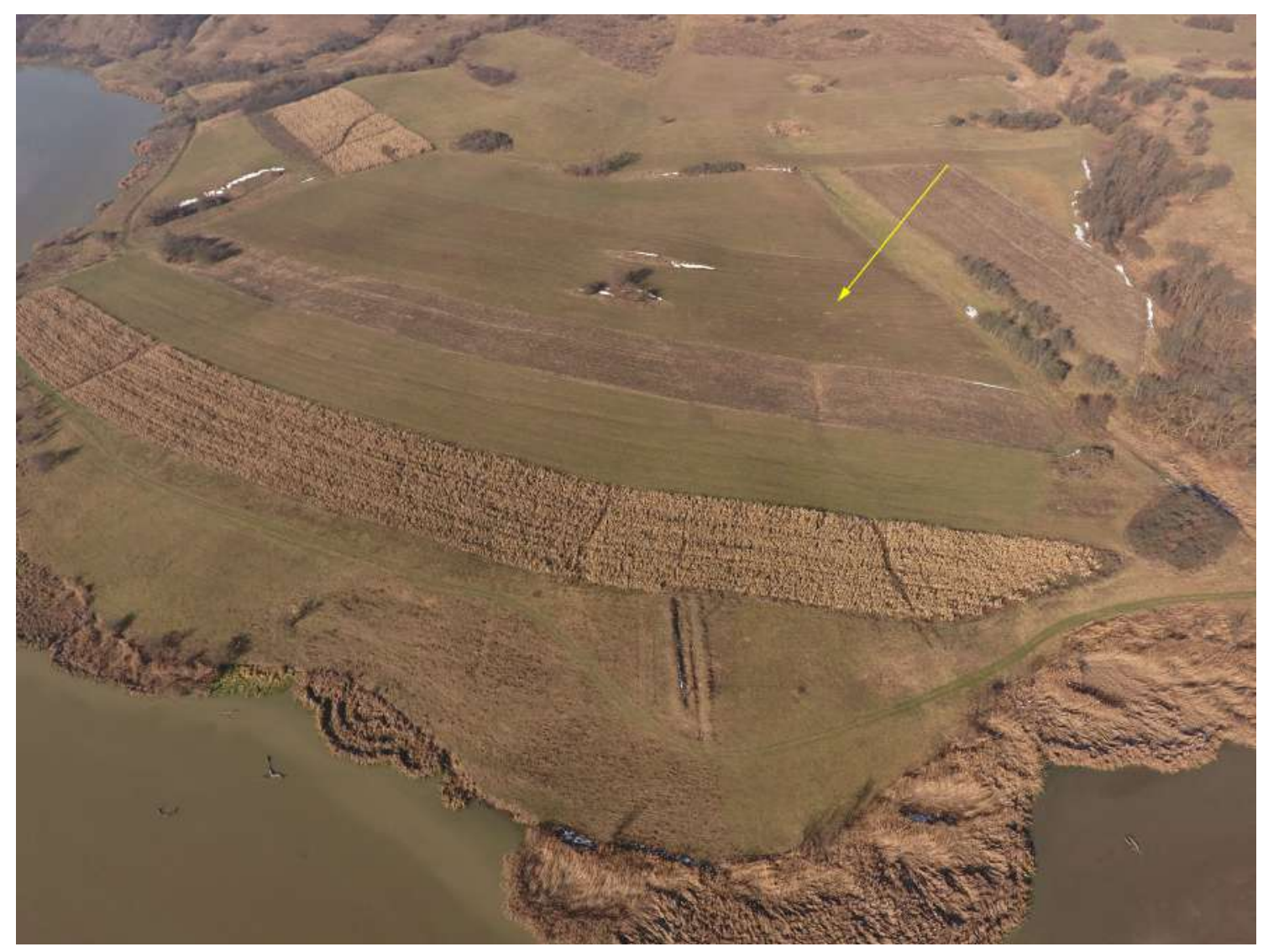

3.5. Cincşor, fotografie oblică din dronă, vedere dinspre Sud-Est (noiembrie 2016).

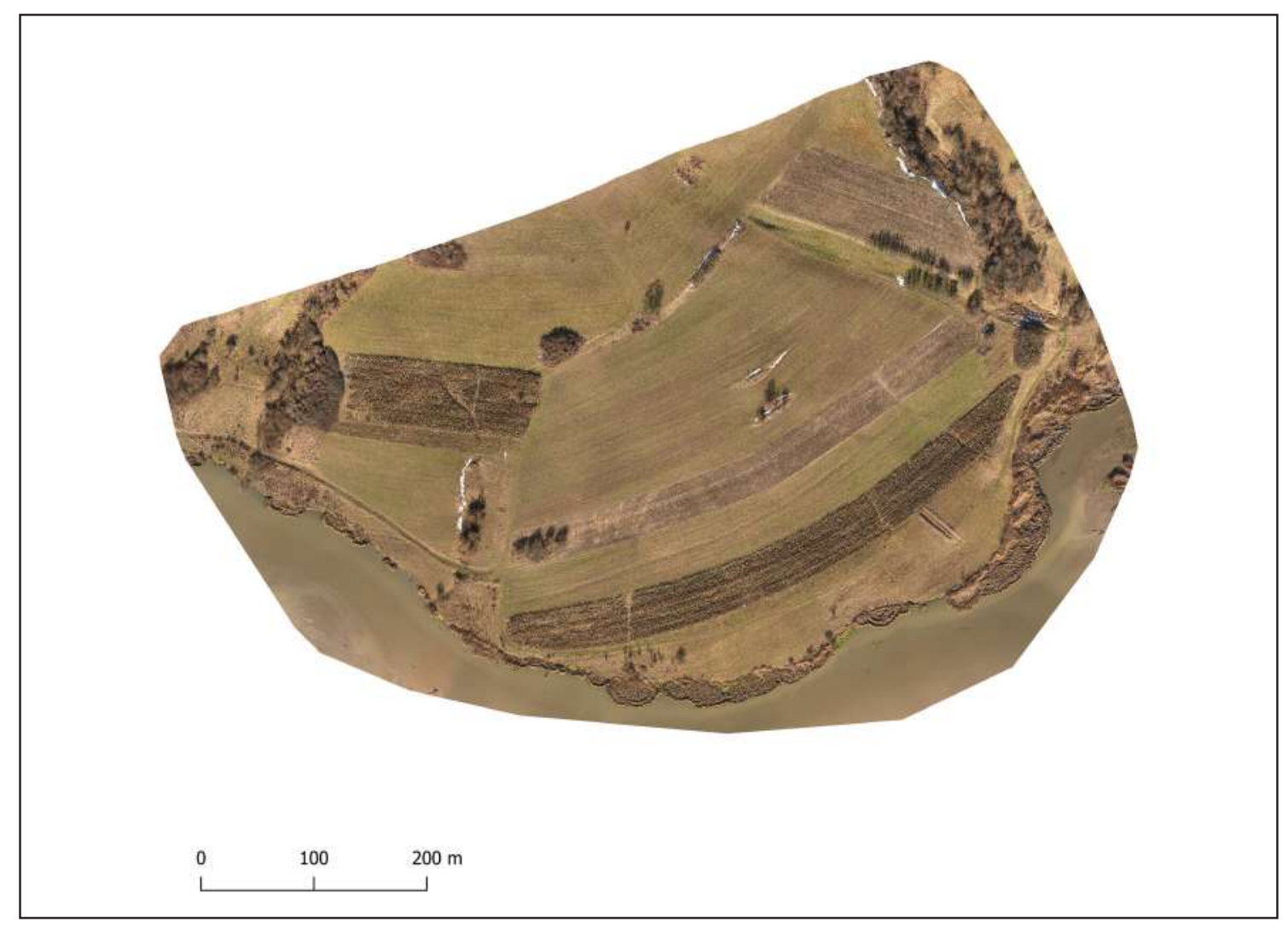

3.6. Cincşor, ortofotoplan dronă. 


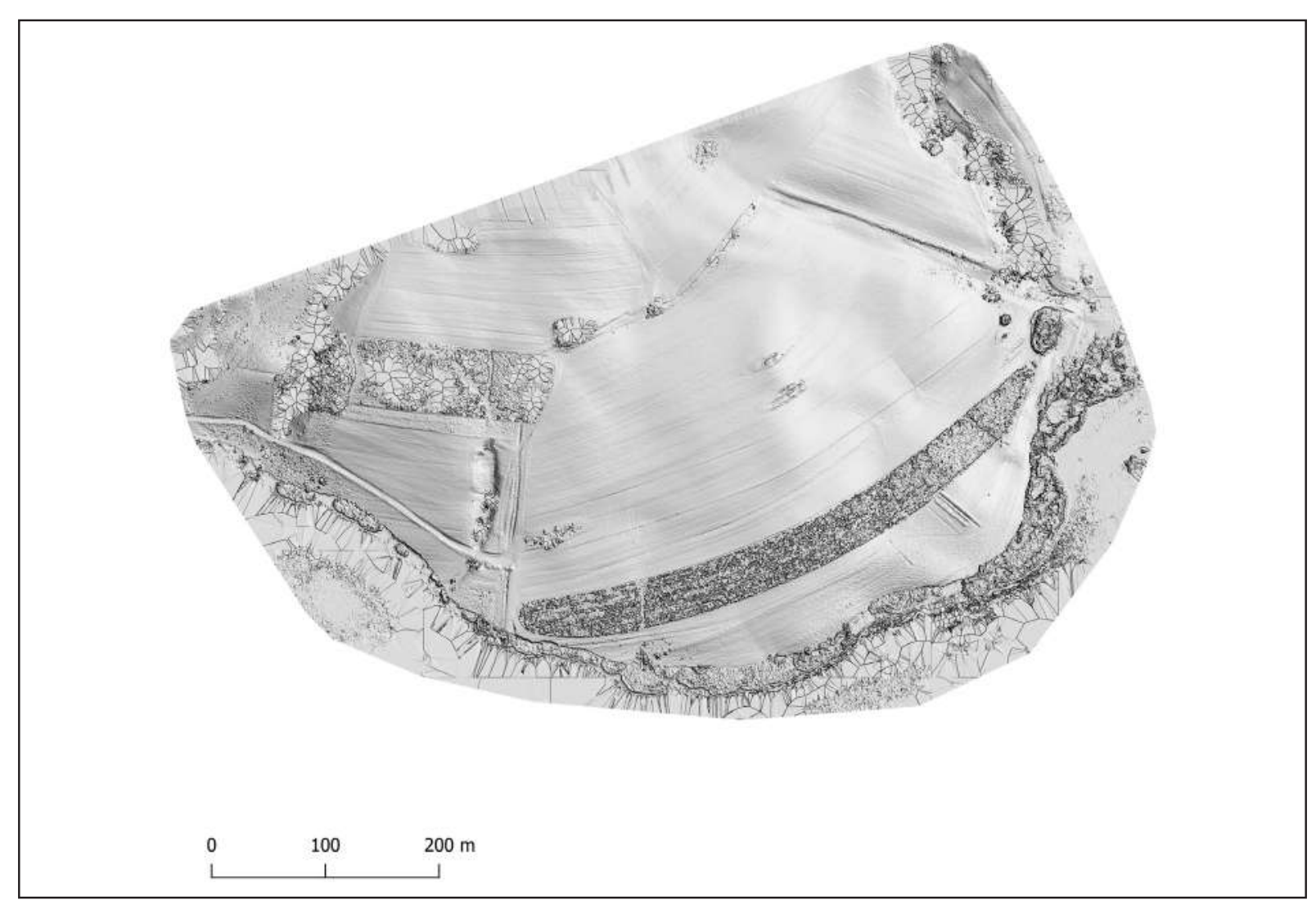

3.7. Cincşor, model digital umbrit (hillshade).

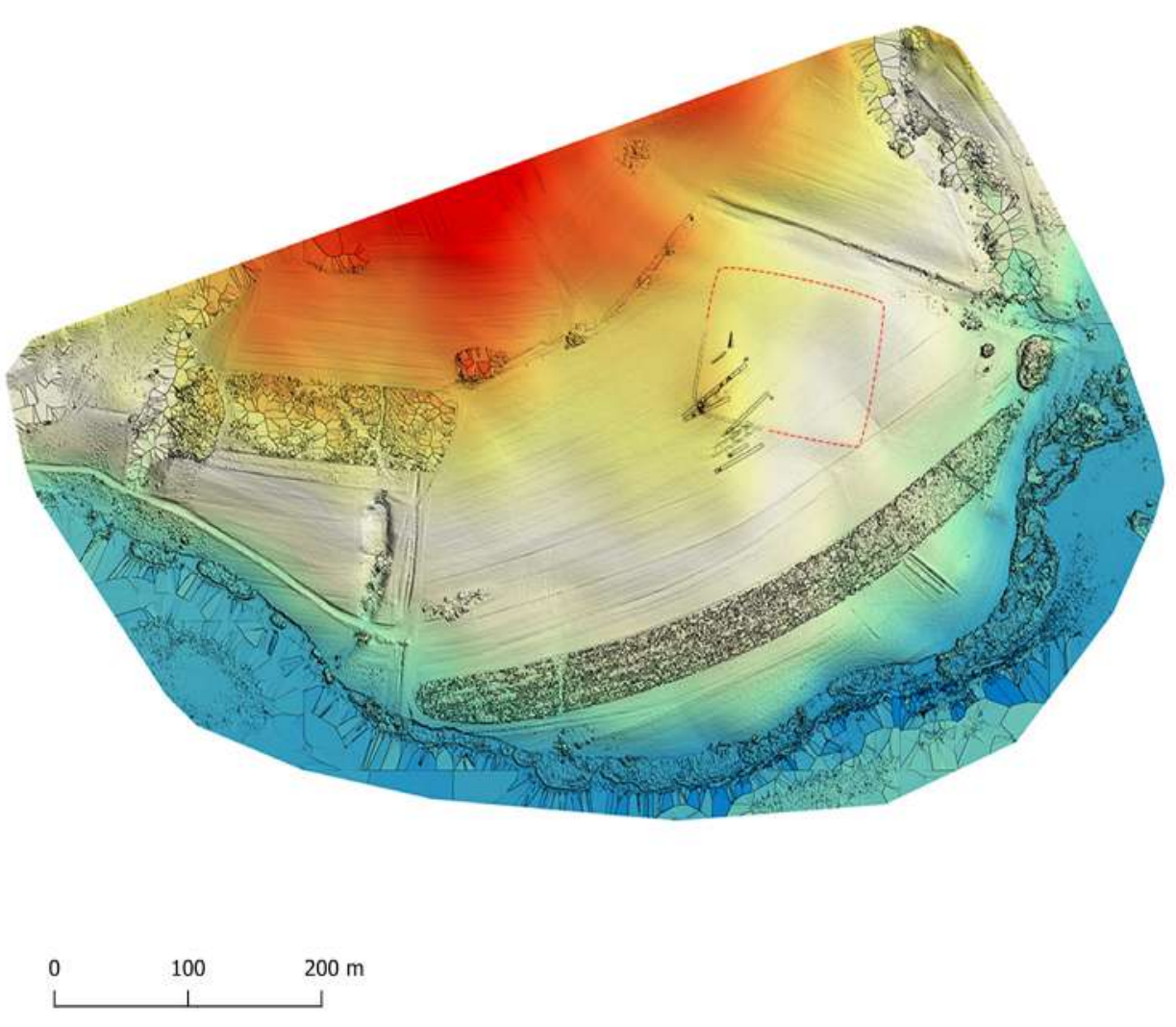

3.8. Cincşor, reconstituirea planului (Isac, Isac 1994, 105, fig. 2) suprapus pe modelul digital al terenului. 


\section{Feldioara}

Com. Ucea, jud. Braşov (RAN: 42138.01; BV-I-m-A-11277)

Urmele vizibile la suprafață, aparținând castrului auxiliar sunt vizibile la Sud de satul actual, pe malul drept al Oltului, pe o terasă joasă, în punctul Cetăţea/ Cetate (fig. 4.1, 4.2). Este vizibilă o porțiune mai ridicată, sub forma unui val de pământ, corespunzătoare colțului de Nord-Est. Săpăturile întreprinse de N. Gudea și I. Pop (1973-1979) au evidențiat două faze de construcție. Primul castru avea un val de $8 \mathrm{~m}$ lățime și 1,25 m înălțime și șanț de apărare cu o deschidere de 11 $\mathrm{m}$ şi $1,25 \mathrm{~m}$ adâncime. Au fost identificate amprentele aparținând porţilor de lemn pe laturile de NE şi NV. Din castrul cu incintă de piatră au putut fi semnalate două laturi pe o lungime de $137 \mathrm{~m}$, respectiv 114 m, având aceeași orientare cu fortificația anterioară. $\mathrm{Au}$ fost cercetate porta praetoria, pe latura de Nord-Est, şi porta principalis sinistra, pe latura de Nord-Vest, un turn de colț de formă trapezoidală și un turn de curtină dreptunghiular. În interior, au fost identificate parțial două barăci din praetentura sinistra (fig. 4.5).

Pe baza materialul tegular, a fost identificată stationarea cohors II Flavia Numidarum (IDR III 4, 174,176-177 - Antoniniana).

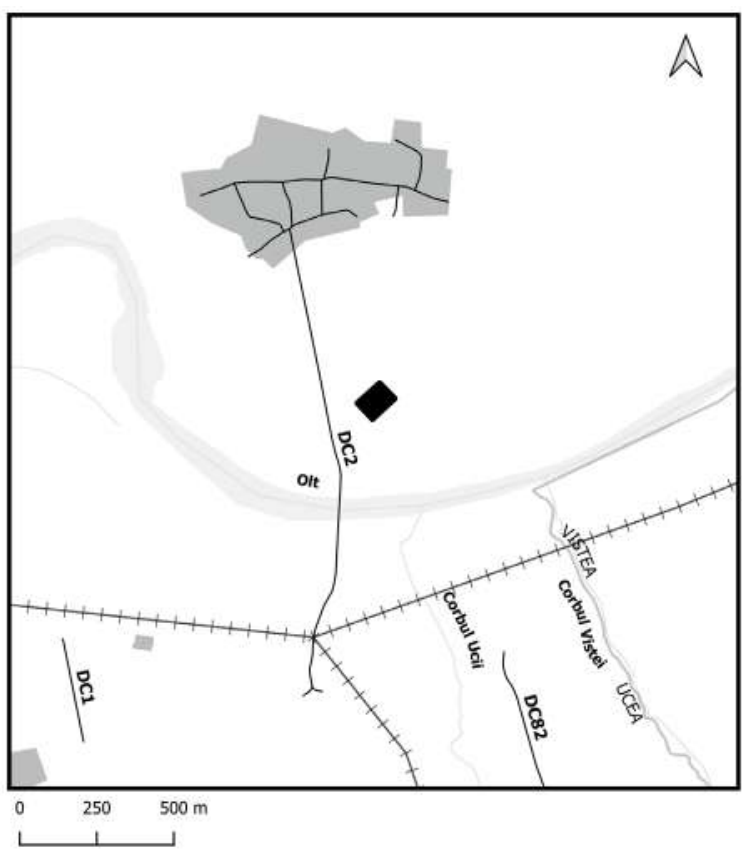

4.1. Feldioara, localizarea castrului.

Urmele valului păstrat al fortificației sunt vizibile parțial pe teren. De asemenea, pe teren pot fi vizibile artefacte fragmentare pe teritoriul așezării civile.

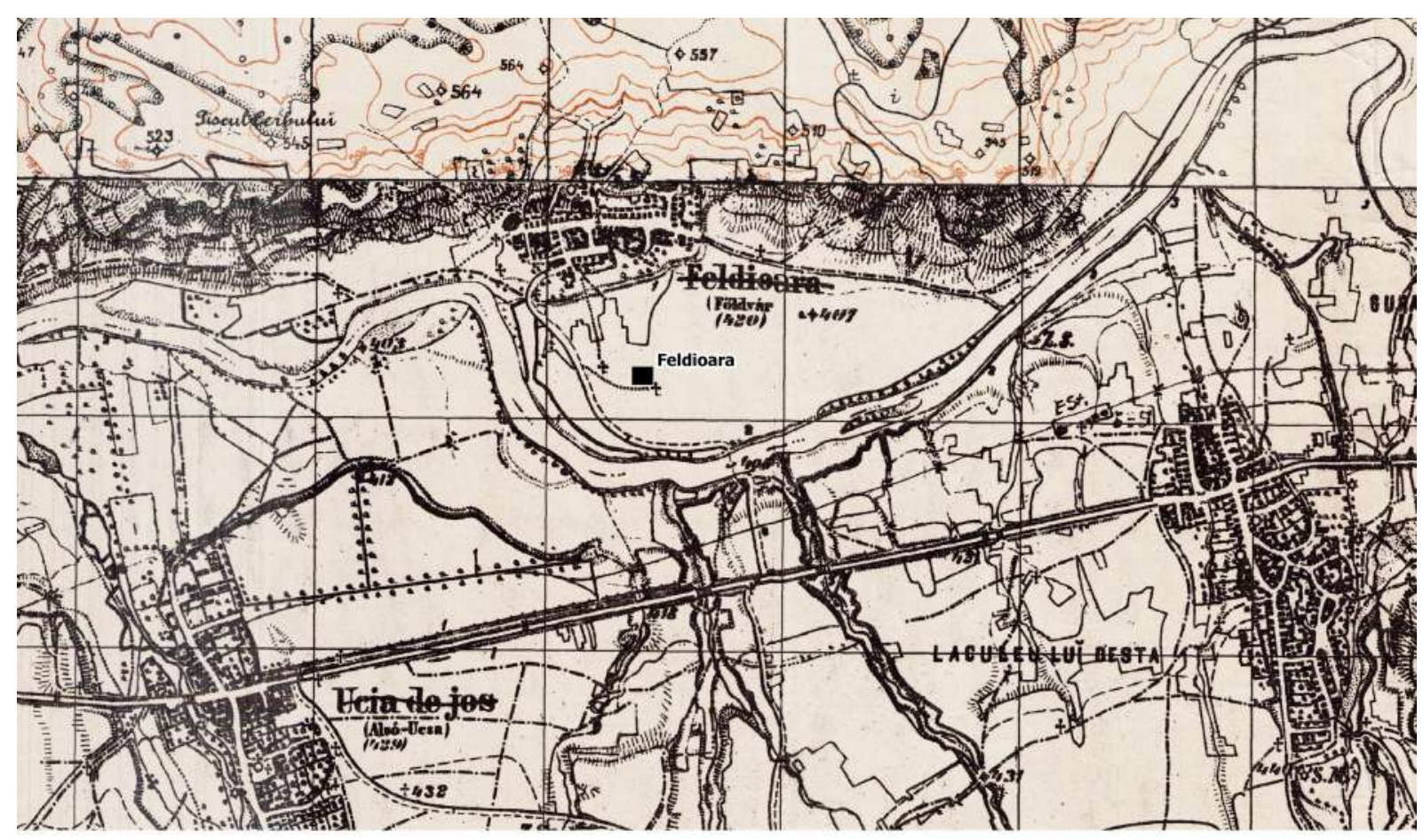

$0.5 \quad 1 \mathrm{~km}$

4.2. Feldioara, localizarea castrului pe Planurile directoare de tragere. 
Bibliografie: Christescu 1937, 190; Tudor 1968, 282; TIR L 35, 41; Gudea, N. și Pop, I 1977. Un castru nou descoperit în sistemul defensiv al Daciei romane: castrul roman de la Feldioara. Pontica 10: 333-338; Gudea, N. și Pop, I 1980. Săpăturile din castrul roman de la Feldioara. Materiale şi cercetări arheologice. A XIV-a Sesiune anuală de rapoarte, Tulcea, București: Editura Academiei Române: 289-291; Bogdan-Cătăniciu 1981, 84 n. 271; Vlădescu 1983, 115, nr. 22; Vlădescu 1986, 80-81; Gudea 1997, 68-69, 45; Gudea 2005, 496-497, nr. VII. B. 7; Marcu 2009, 205-206, nr. 51.

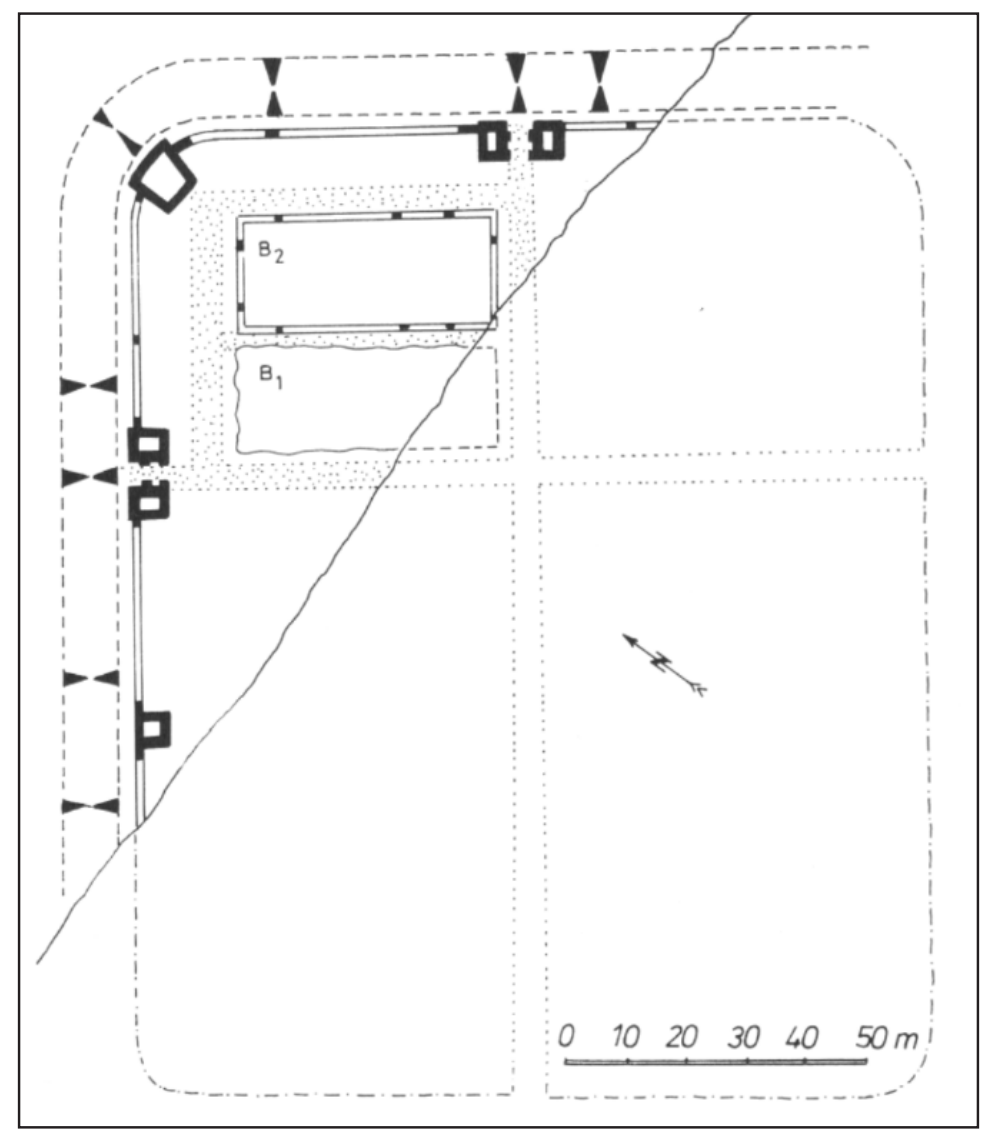

4.3. Feldioara, planul castrului (Gudea 1997, 69, nr. 45).

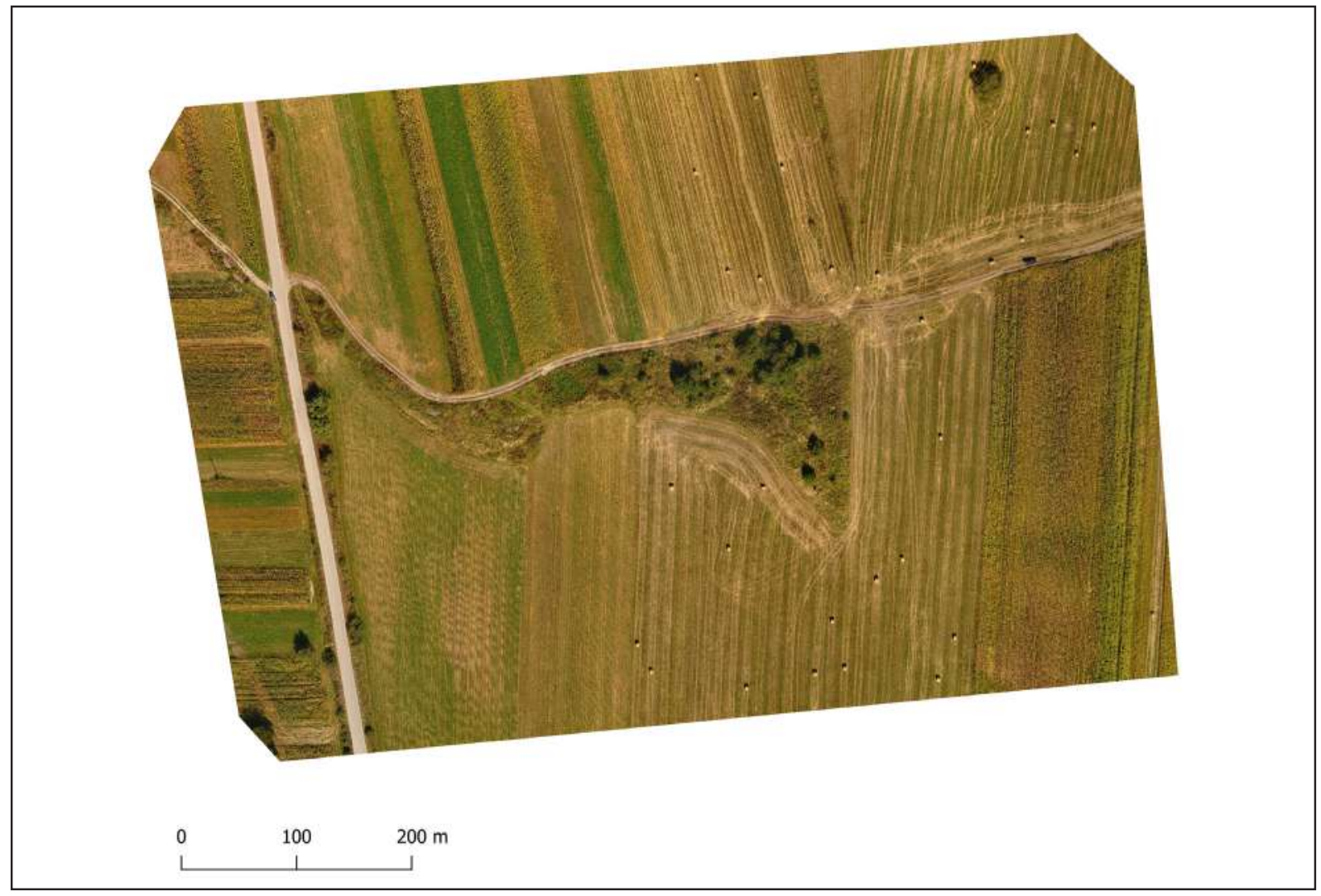

4.4. Feldioara, ortofotoplan dronă. 


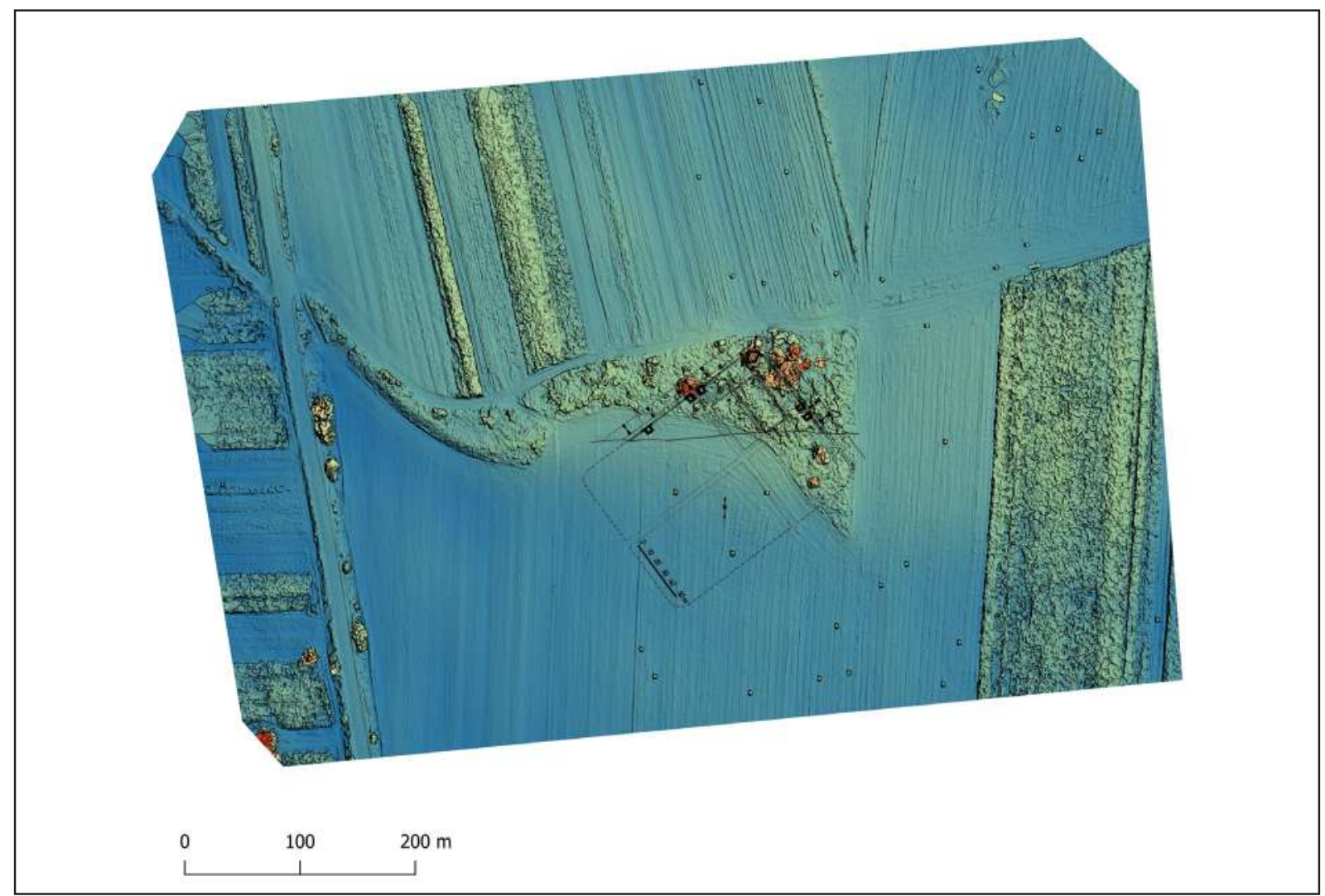

4.5. Feldioara, plan (Gudea 1997, 69, nr. 45) suprapus pe modelul digital al terenului.

\section{Boiţa (Caput Stenarum?, Tabula Peutingeriana VIII, 1)}

Com. Tălmaciu, jud. Sibiu (RAN: 145845.01, SB-I-m-A11946.01)

Fortificația romană de la Boița (fig. 5.1) este amplasată în imediata apropiere a curburii Oltului înainte de a intra în defileu. La aproximativ doi km Est de satul actual, în punctul Rude/La Rude, pe terasa înaltă din dreapta Oltului, sunt vizibile urme parțiale ale fortificației romane, mai ales pământul rezultat din săpăturile arheologice, fără a se distinge ruine. Pe câmp, în urma lucrărilor agricole, se pot identifica cu ușurință numeroase urme de factură romană, în special la marginea terasei înalte, la Sud-Est de fortificație (fig. 5.3, 5.4).

În urma cercetărilor arheologice (M. Macrea şi colab. 1957; N. Lupu 1958; 1968-1976; N. Branga 1979), nu a fost publicat un plan coerent. Ioana Bogdan-Cătăniciu a propus unele completări ale elementelor defensive ale fortificației (fig. 5.2).

Avem de a face cu o fortificație patrulateră, cu colțuri rotunjite și dimensiunile $45 \times 50 \mathrm{~m}$; zid dublu de $1,50 \mathrm{~m}$ grosime, înconjurat cu un șanț dublu de apărare; pe latura de $\mathrm{V}$ a fost identificată parțial o poartă. Descoperirea unei ștampile cu numele legiunii XIII Gemina (IDR III 4, 84) a condus la formularea ipotezei prezenţei unui detaşament de construcție al legiunii în primii ani ai stăpânirii romane în Dacia (Bauvexillation ?). De asemenea, A fost descoperită o ștampilă de tipul COH I... (IDR III 4, 85), atribuită cohortei I Tyriorum sag, respectiv I (Flavia) Commagenorum sag., fără a exista în acest moment elemente decisive în favoarea niciunei ipoteze. Pe baza acestui argument, dar fără a exista suficiente elemente pentru stabilirea unei cronologii, putem vorbi în acest moment despre utilizarea materialului ceramic de construcție, marcat cu aceste ștampile.

La $80 \mathrm{~m}$ Sud de fortificație, a fost identificată o construcție de dimensiuni mari $(20 \times 50 \mathrm{~m})$ a cărei cercetare arheologică nu a fost finalizată. Instalațiile de încălzire și de îmbăiere pot aparține băilor utilizate de garnizoana fortificației sau unui complex de dimensiuni mai mari. În apropiere au fost descoperite resturile unei clădiri $(11 \times 10,5 \mathrm{~m})$, interpretată de N. Lupu ca o statio sau un tabularium portorii.

De jur împrejurul fortificației pot fi semnalate urme de fragmente ceramice, provenind din așezarea civilă, de pe teritoriul căreia, la aproximativ $60 \mathrm{~m}$ la Nord-Vest de fortificație, în ruinele unei construcții cu fundație de piatră și 
structură de lemn, a fost descoperit un tezaur monetar îngropat probabil în contextul invaziei carpice din 247 p. Chr.

Cele mai importante structuri descoperite se situează la limita terasei superioare de pe malul drept al Oltului, la o distanță de aproximativ 500 m Est de curbura râului, zonă în care drumul se ramifica către defileul Oltului, respectiv către Apulum.

Integrarea datelor colectate în ultimii ani ne oferă imaginea parțială a fortificației, a unor construcții din aşezarea civilă, precum și a relaţiei acestora cu principalele artere de comunicare, rutiere sau fluviale. Rezultatele măsurătorilor geofizice (fig. 5.8) au confirmat existența unor structuri constructive în acest areal, însă acestea au avut un caracter restrâns din cauza accesului limitat pe parcelele cultivate care acoperă situl.

Bibliografie: Christescu 1937, 108; Macrea, M. 1959. Şantierul arheologic Caşolţ - Boiţa. Materiale şi Cercetări Arheologice 6: 407-437; Lupu, N. 1960. Săpăturile de la Boiţa. Materiale și Cercetări Arheologice 7: 411-422; Tudor 1968, 372; TIR L

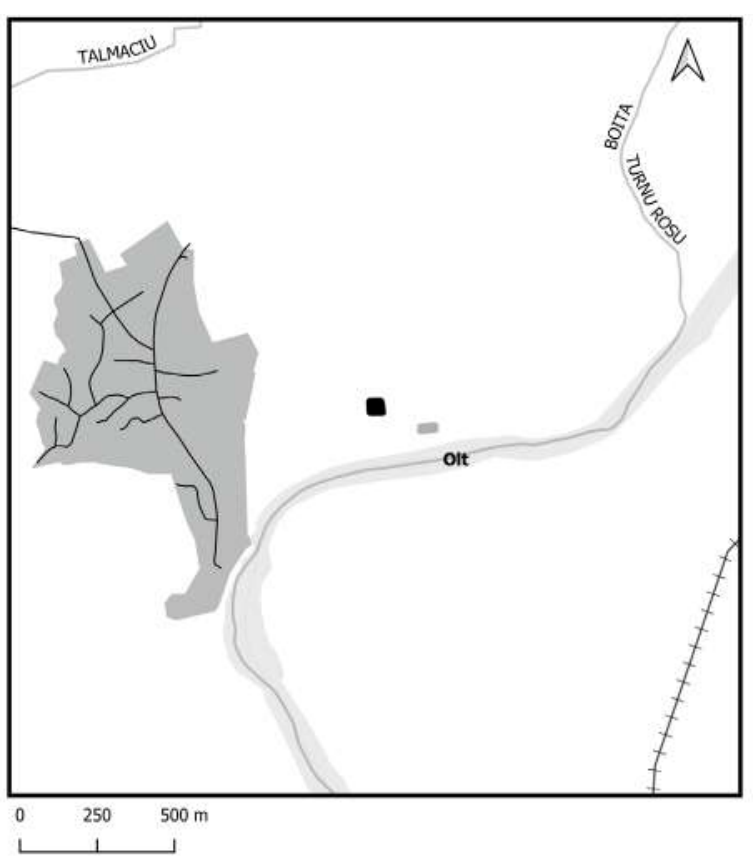

5.1. Boița, localizarea castrului și a băilor. 35, 30; Tudor 1978, 270-271, nr. 9, 315 (termele);

Vlădescu 1983, 114-115, nr. 21; Vlădescu 1986, 79-80; Albescu, I. 1990. Boița. Monografie istorică, Sibiu: 112; Gudea 1997, 69-70, nr. 46; Lupu, N. 2002. Staţiunea romană de la Boiţa (jud. Sibiu). Acta Terrae Septemcastrensis 1: 71-106; Dudău 2006, 65, nr. 11; 97; Marcu 2009, 187-188, nr. 40; Țentea, O. 2012. Ex Oriente ad Danubium. The Syrian auxiliary units on the Danube frontier of the Roman Empire, București: Mega: 66; Schuster, C. 2013. Castelul de la Caput Stenarum şi Cohors I Flavia Commagenorum, Terra Sebus. Acta Musei Sabesiensis 5: 237253.

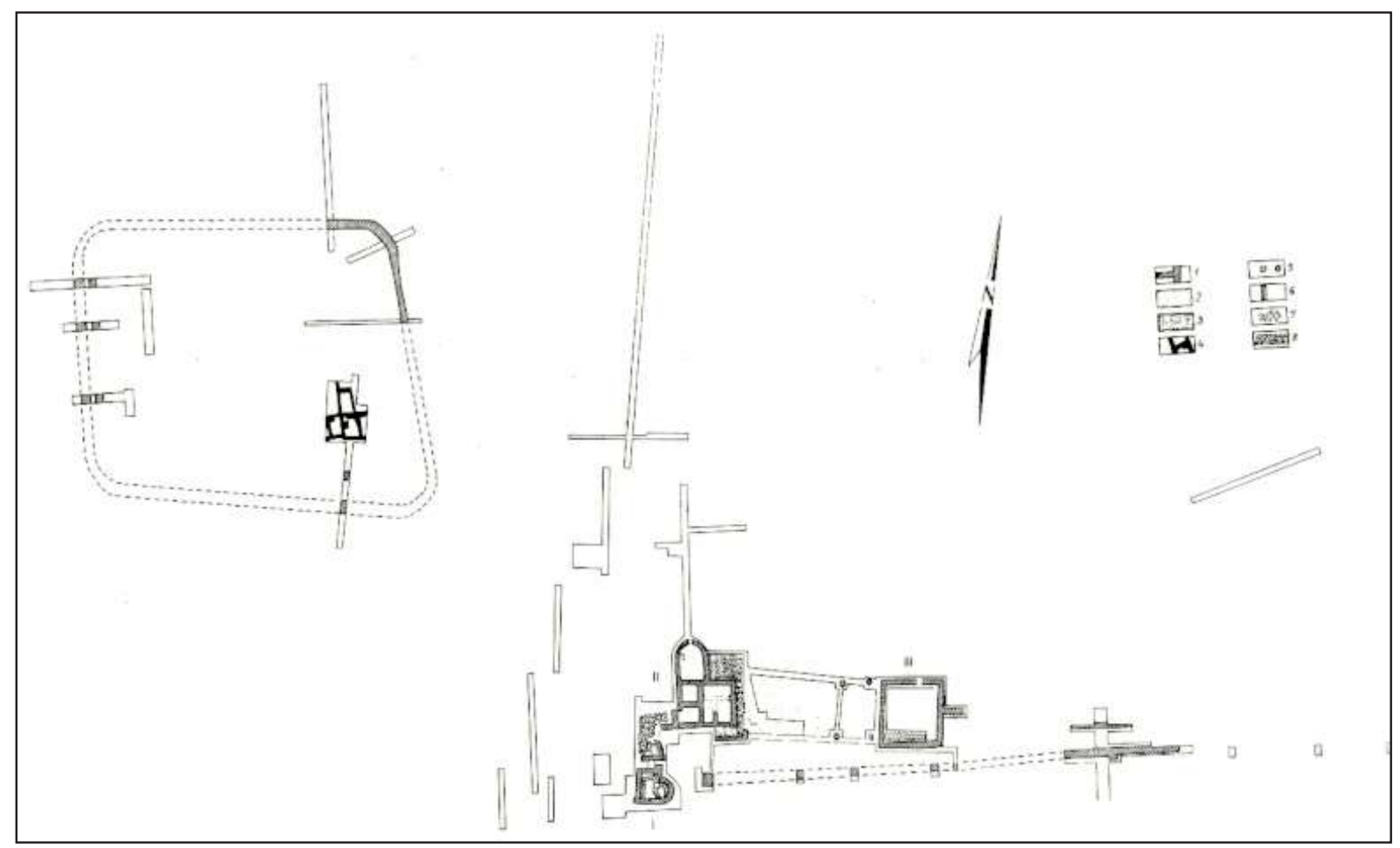

5.2. Boița, planul sitului (Bogdan-Cătăniciu 1981, fig. 53). 


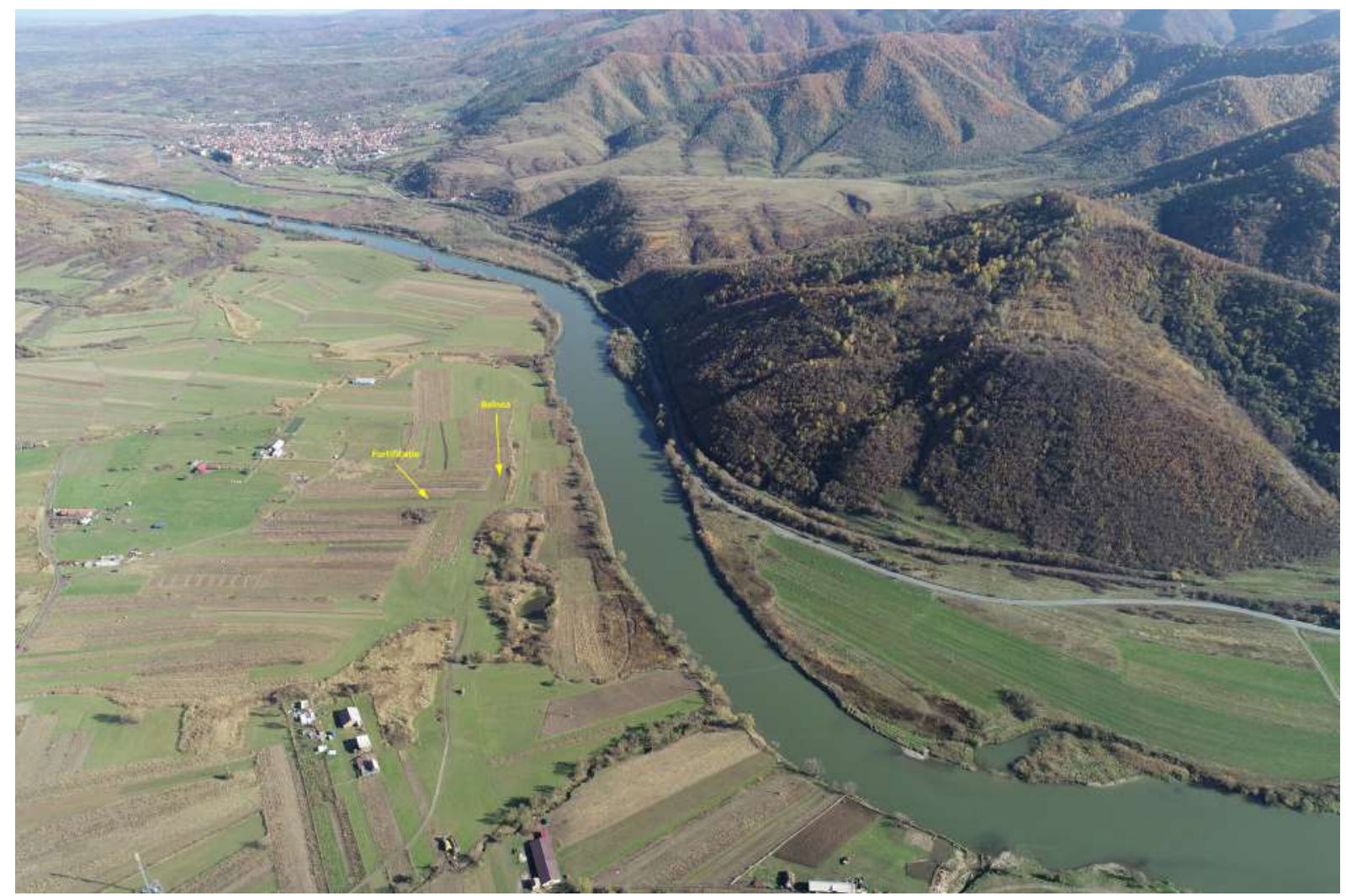

5.3. Boița, fotografie oblică din dronă, vedere dinspre vest (noiembrie 2020).

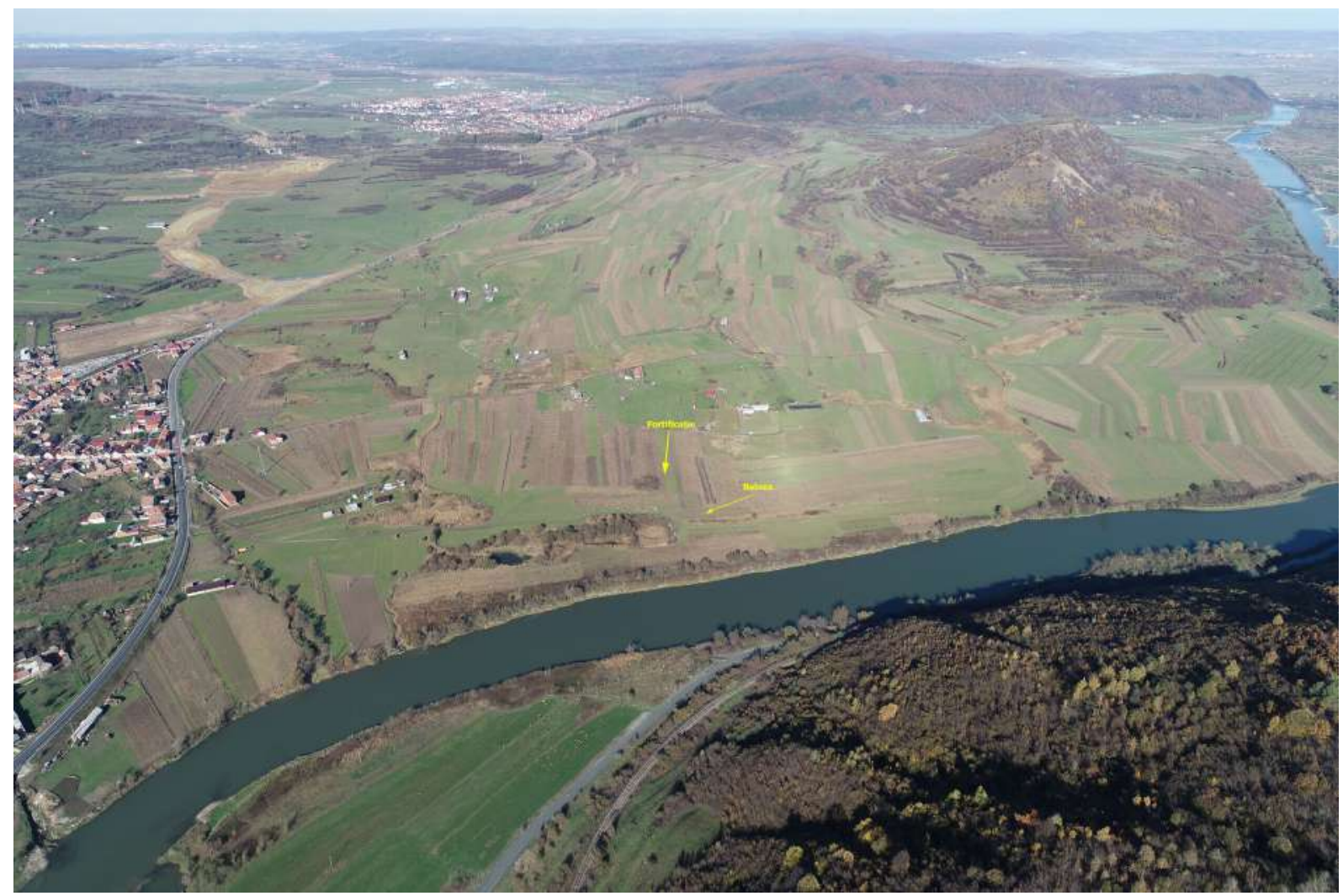

5.4. Boița, fotografie oblică din dronă, vedere dinspre Sud (noiembrie 2020). 


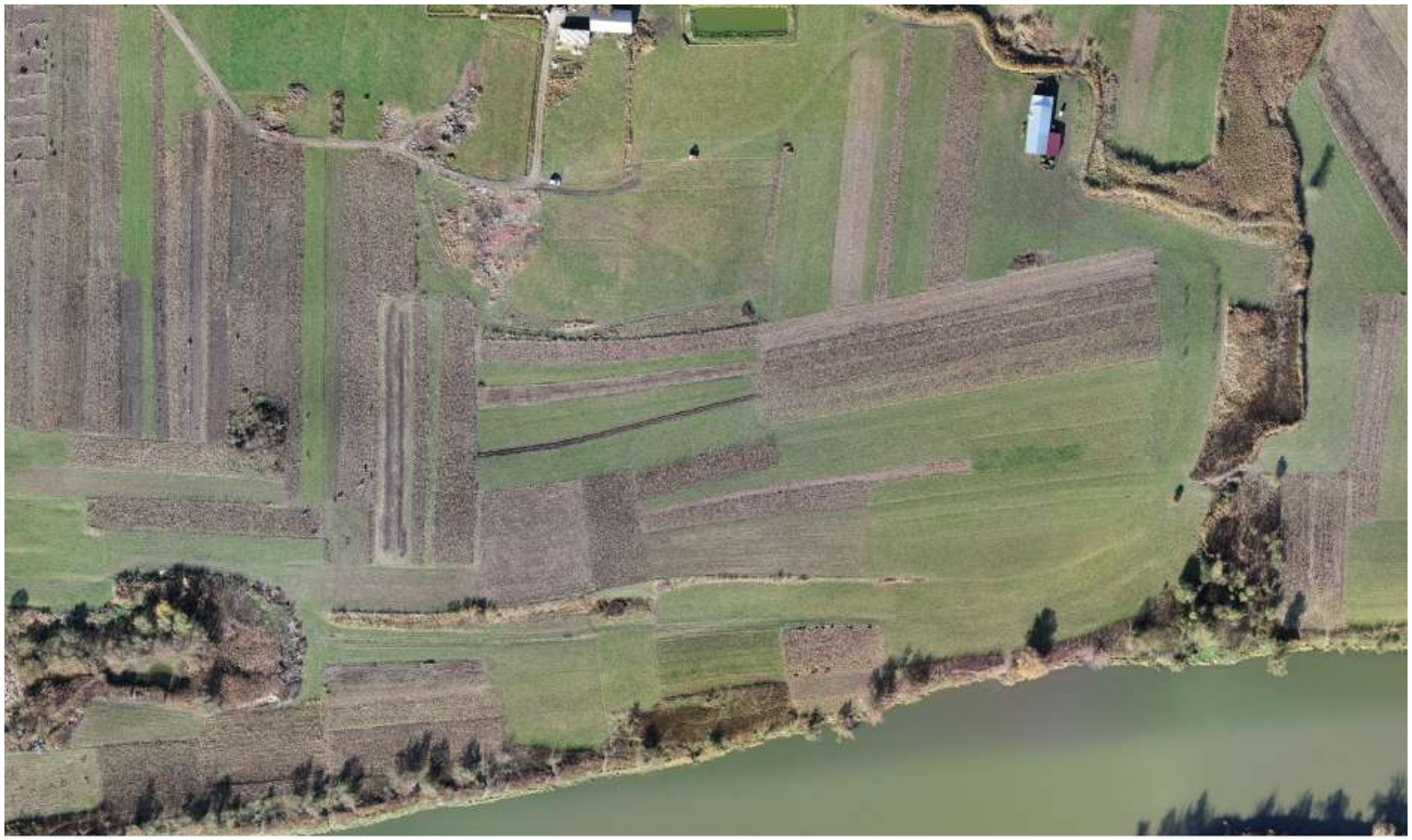

$100 \mathrm{~m}$

5.5. Boița, ortofotoplan dronă.

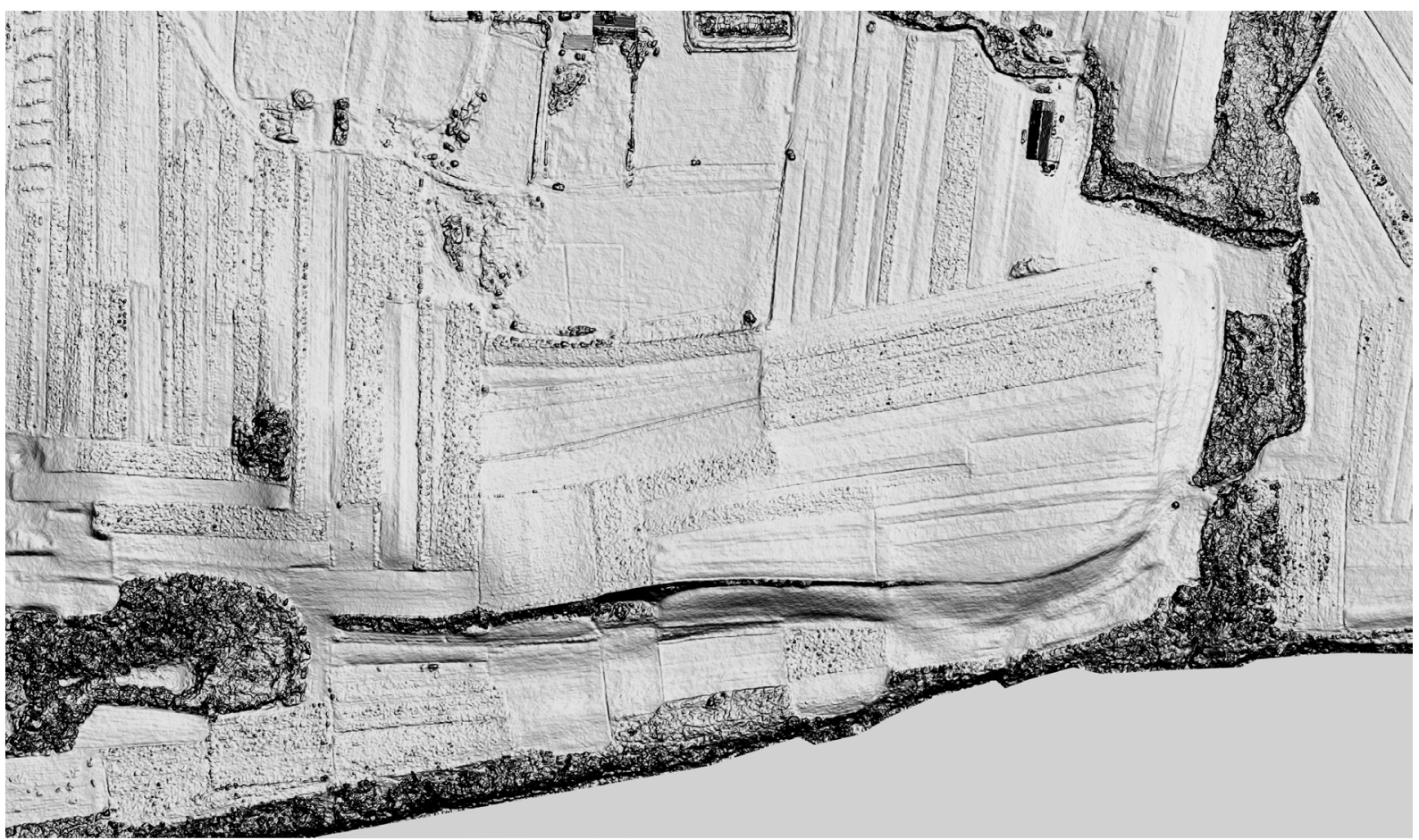

$0 \quad 50 \quad 100 \mathrm{~m}$

5.6. Boița, model digital umbrit (hillshade) 

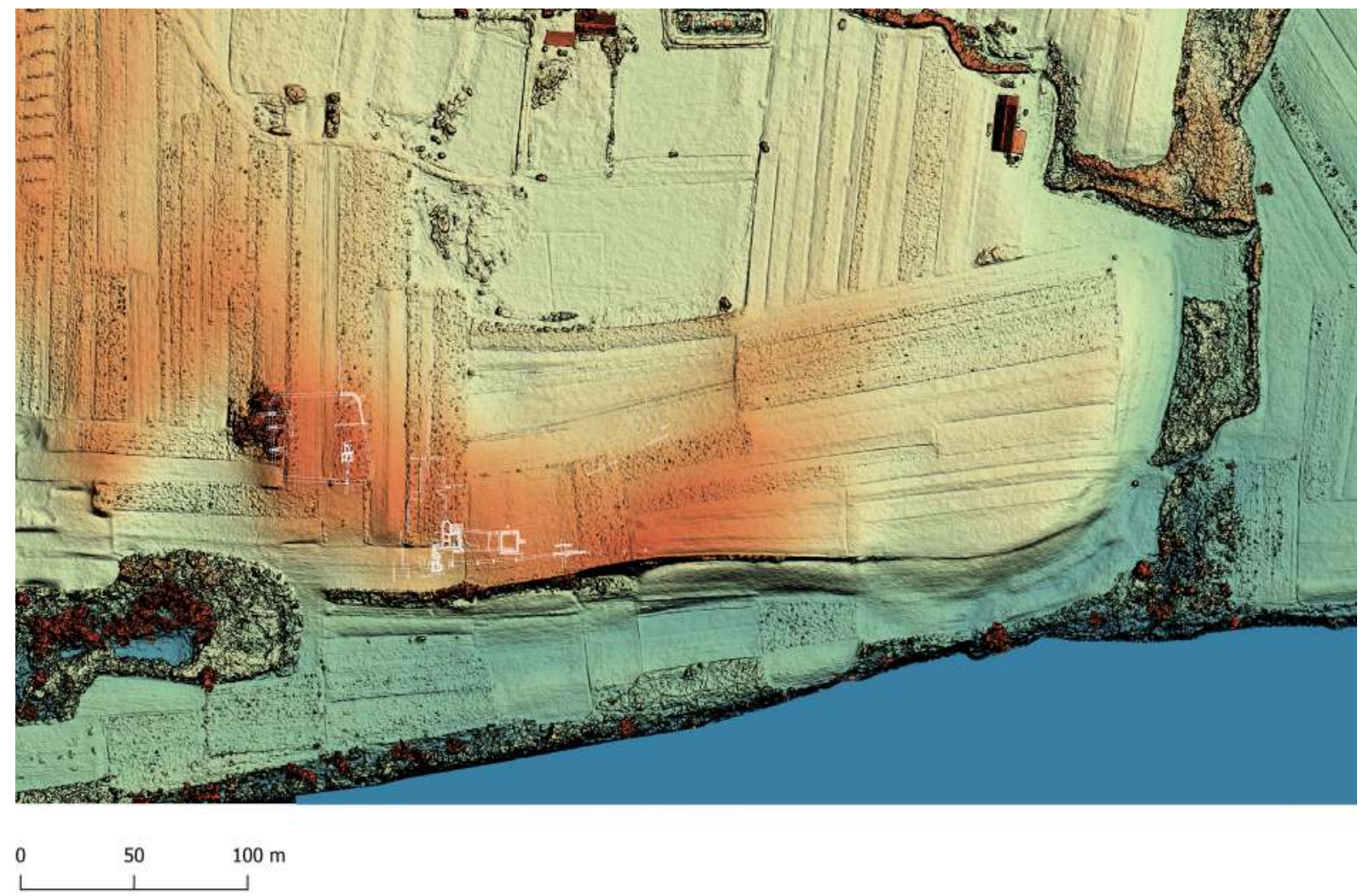

5.7. Boița, planul sitului (Bogdan-Cătăniciu 1981, fig. 53) suprapus pe modelul digital al terenului

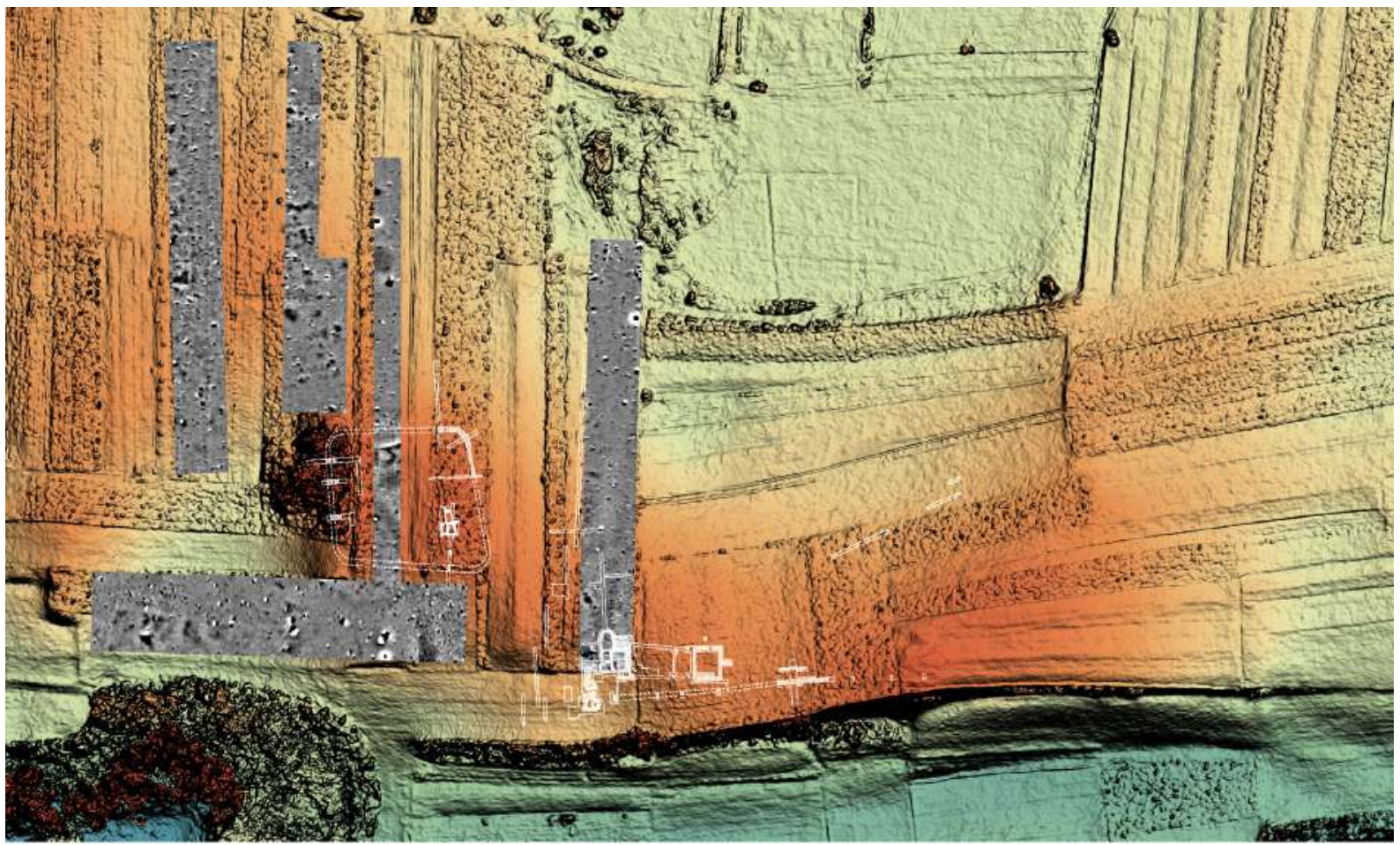

$0 \quad 25 \quad 50 \mathrm{~m}$

5.8. Boița, planul prospecțiunilor geofizice suprapus pe modelul digital al terenului. 


\section{Râul Vadului}

Com. Câineni, jud. Vâlcea (RAN: 169164.02)

Menționarea unui castru (fig. 6.1 și 6.2) a fost argumentată pe baza unor notițe provenite de la L. F. Marsigli în punctul numit de acesta "Citateșu", ulterior „Poarta lui Traian”.

Cr. M. Vlădescu nota faptul că într-o recunoaștere de teren din anul $1976 \mathrm{nu}$ a identificat urmele niciunui castru menționat la Câineni (Vlădescu 1986, 79). Pe baza unor informații verbale realizează un sondaj care nu a condus la rezultate relevante. Recunoașterile la fața locului nu au adus informații suplimentare.

Bibliografie: Tudor 1978, 297; Vlădescu 1986, 121 nota 274.

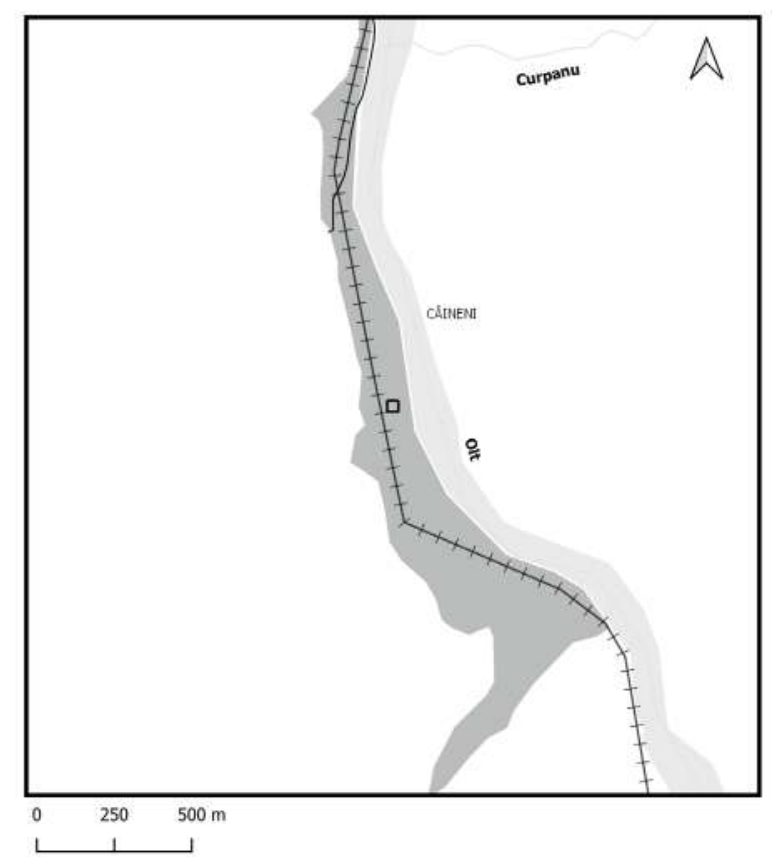

6.1. Câineni. Râul Vadului, localizarea presupusă a sitului.

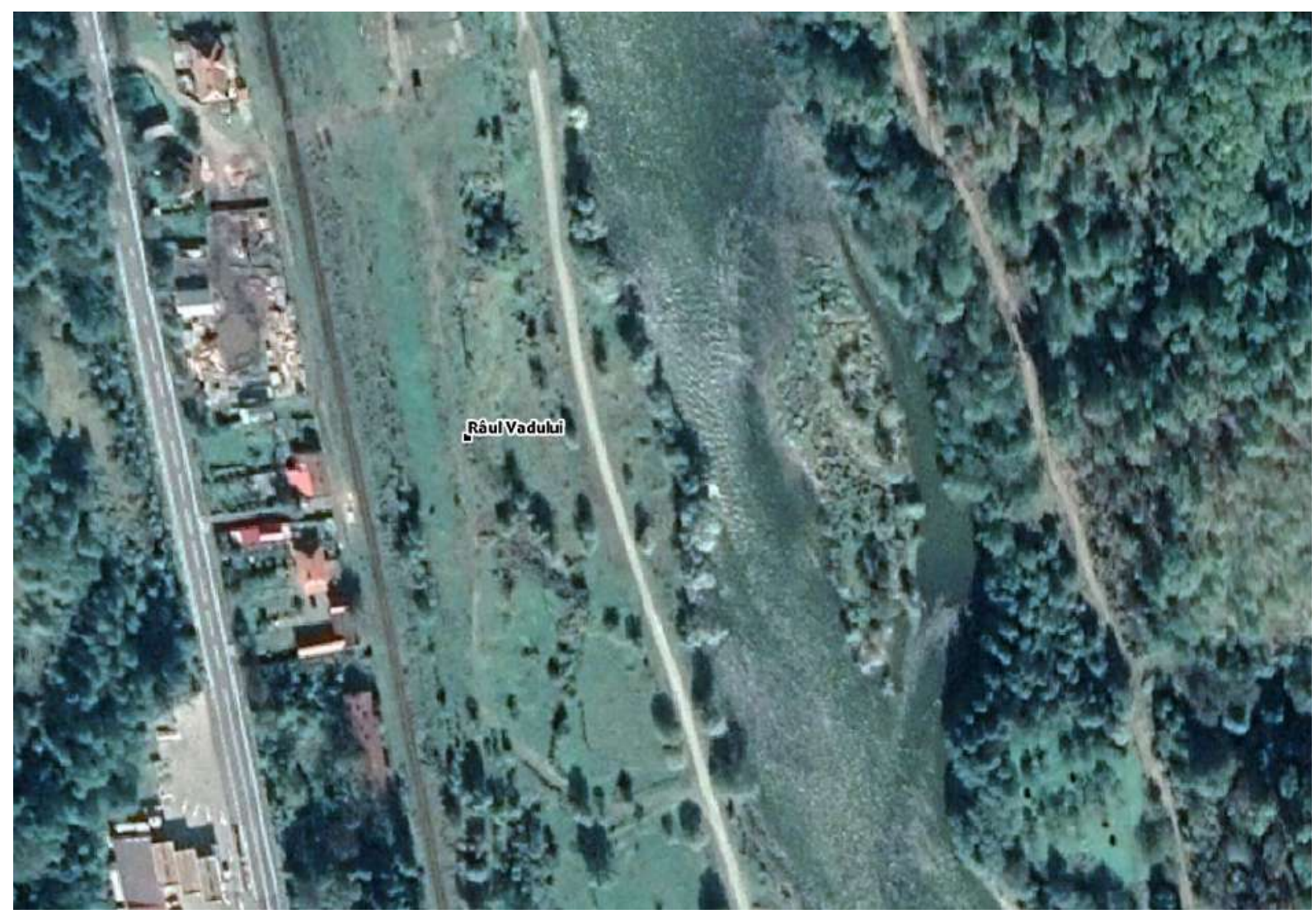

6.2. Câineni. Râul Vadului, localizarea presupusă a sitului, ortofotoplan (Google Earth). 
7. Câineni (Pons Vetus? Tabula Peutingeriana VIII, 1)

Câinenii Mari, com. Câineni, jud. Vâlcea (RAN: 169137.01; VL-I-s-B-09522)

Pe malul stâng al Oltului (fig. 7.1 - 7.4), la Nord-Est de satul Câinenii Mici, punctul la Turnulețe, la vărsarea pârâului satului în râul Olt, a fost presupusă existența unei fortificații (castru?), distruse de apele Oltului. În apropierea punctului în care a fost localizat castrul, în presupusul vicus, a fost descoperit în sec. XIX un tezaur monetar format din monede cuprinse între domniile împăraţilor Hadrianus și Philippus Arabs.

Cr. M. Vlădescu nota faptul că într-o recunoaştere de teren din anul 1976 nu a identificat urmele niciunui castru menționat la Câineni, ci doar ale unui turn de formă pătrată cu latura de aproximativ patru metri. Acesta nu a putut fi cercetat datorită acoperirii de drumul forestier în anul 1979 (Vlădescu 1986, 79, 121 nota 274).

Unii cercetători figurează castrul pe malul drept al Oltului, în Câinenii Mari, pe platoul Malul Podului, lângă capul vestic al podului actual, unde a fost construită cetatea Arxavia. Cu ocazia construirii acesteia (între 1717-1719), generalul Schwanz consemna că nu a identificat ruinele unei fortificaţii romane la Arxavia, dar că era cu neputinţă ca romanii să nu fi avut, într-adevăr, un castru în acest loc sau în apropiere, posibil în punctul Malul Podului - actualul pod între Câinenii

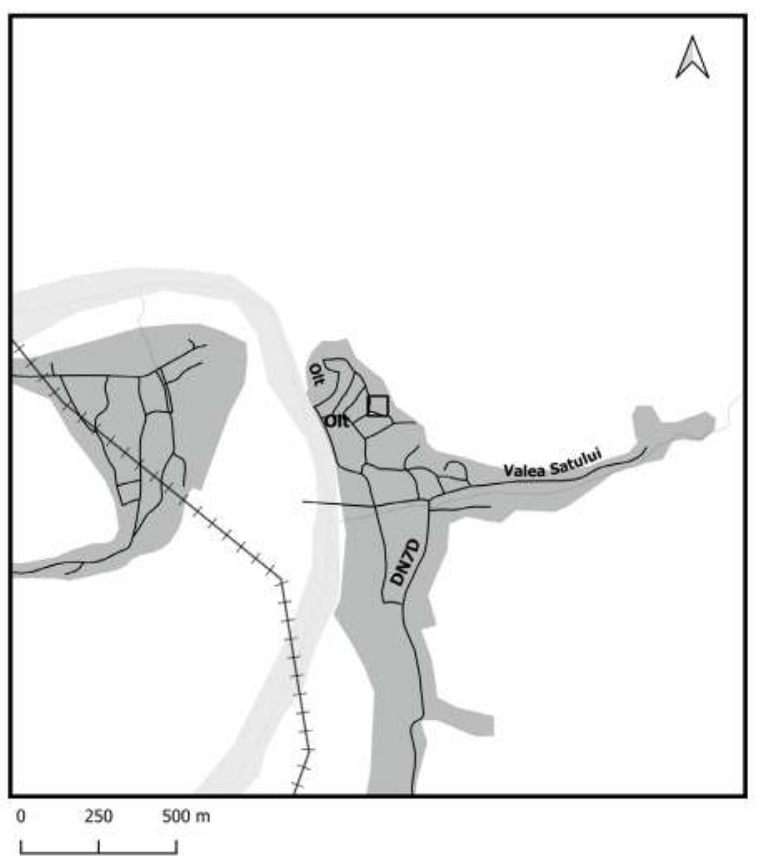

7.1. Câinenii Mici (stânga imaginii), Câinenii Mari (dreapta imaginii), localizarea platoului pe care este amplasată fortificația Arxavia. Mari și Mici (Conea 1935, 94-95).

Cu ocazia unei periegheze din anul $1979 \mathrm{nu}$ au putut fi identificate urme semnificative la fața locului (Vlădescu 1986, 121 nota 274).

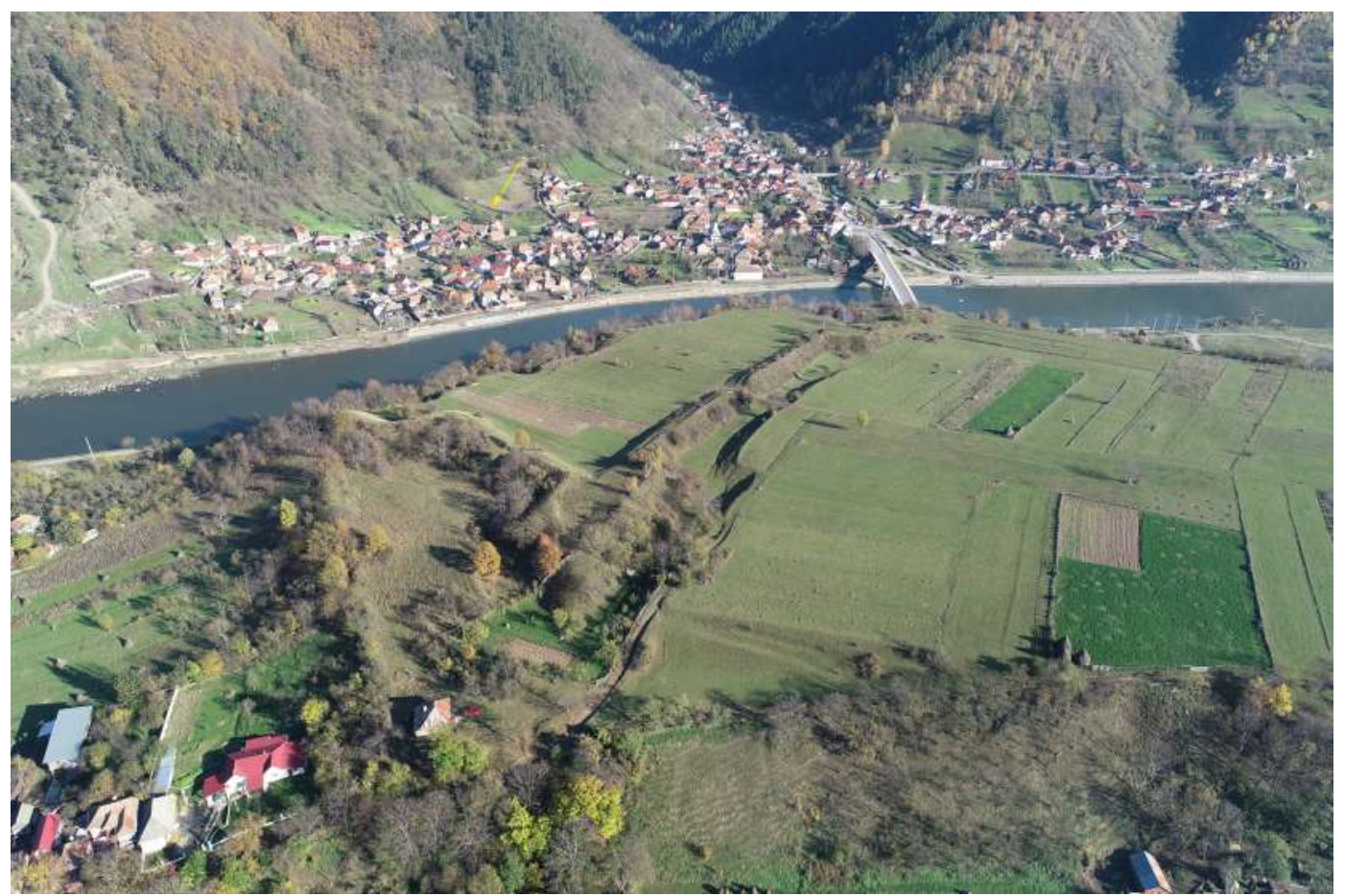

7.2. Câinenii Mici (stânga imaginii), Câinenii Mari (dreapta imaginii), localizarea presupusă a sitului în proximitatea fostului vad din zona podului actual, fotografie oblică din dronă, vedere dinspre vest (noiembrie 2020). 


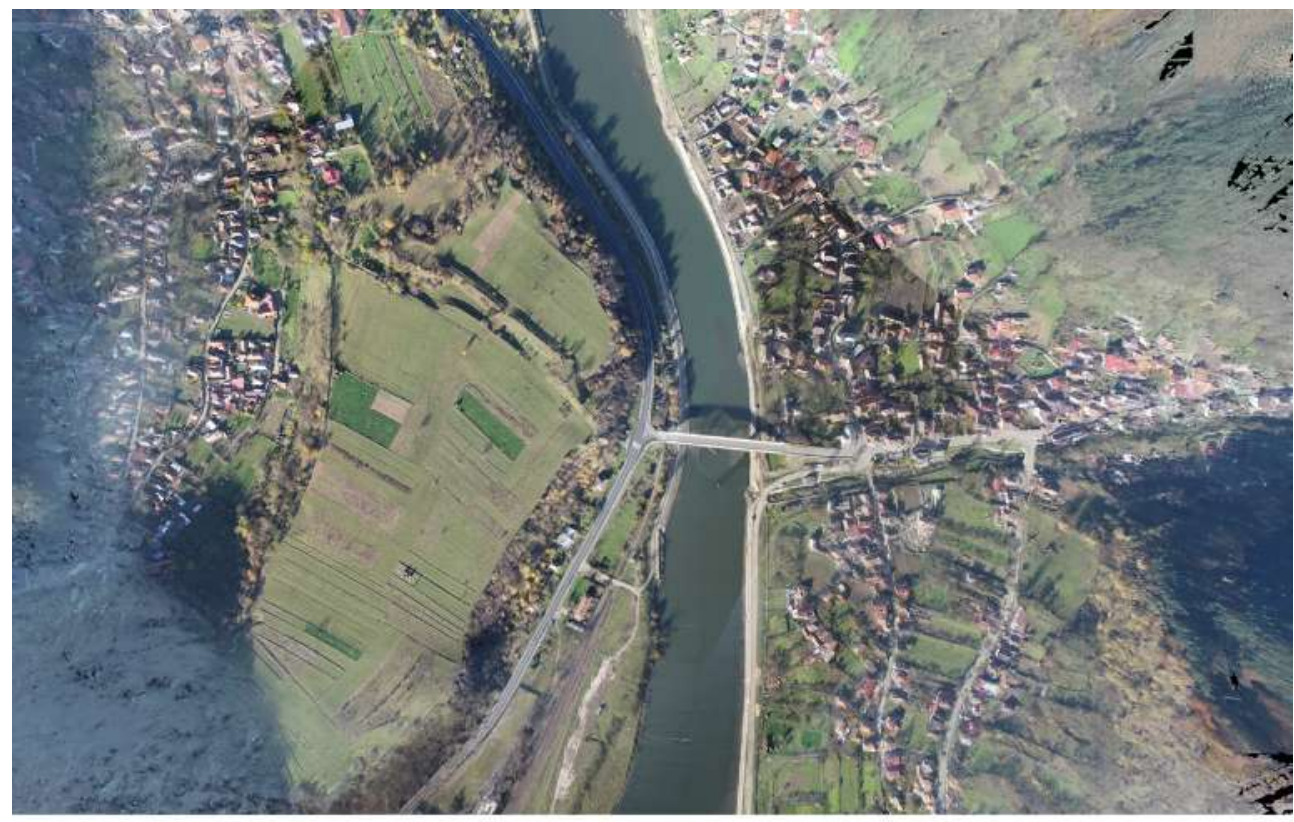

$0 \quad 100 \quad 200 \mathrm{~m}$

\subsection{Câineni, ortofotoplan dronă.}

La Câineni se întâlnesc drumurile de pe valea Loviștei cu cel drumul de pe valea Oltului (Conea 1935, 19, 95, 74). În defileul dintre Câineni şi Boiţa, drumul roman a fost distrus de lucrările la calea ferată, dar P. Polonic 1-a observat în câteva puncte.

Bibliografie: Conea 1935; TIR L 35, 33; Tudor 1978, 287, nr. 30; Bogdan-Cătăniciu 1981, 84 nota 267; Vlădescu 1983, 114, nr. 20; Vlădescu 1986, 79; Gudea 1997, 94, nr. 83; Dudău 2006, 70-71, nr. 19; 104; Marcu 2009, 196, nr. 44.

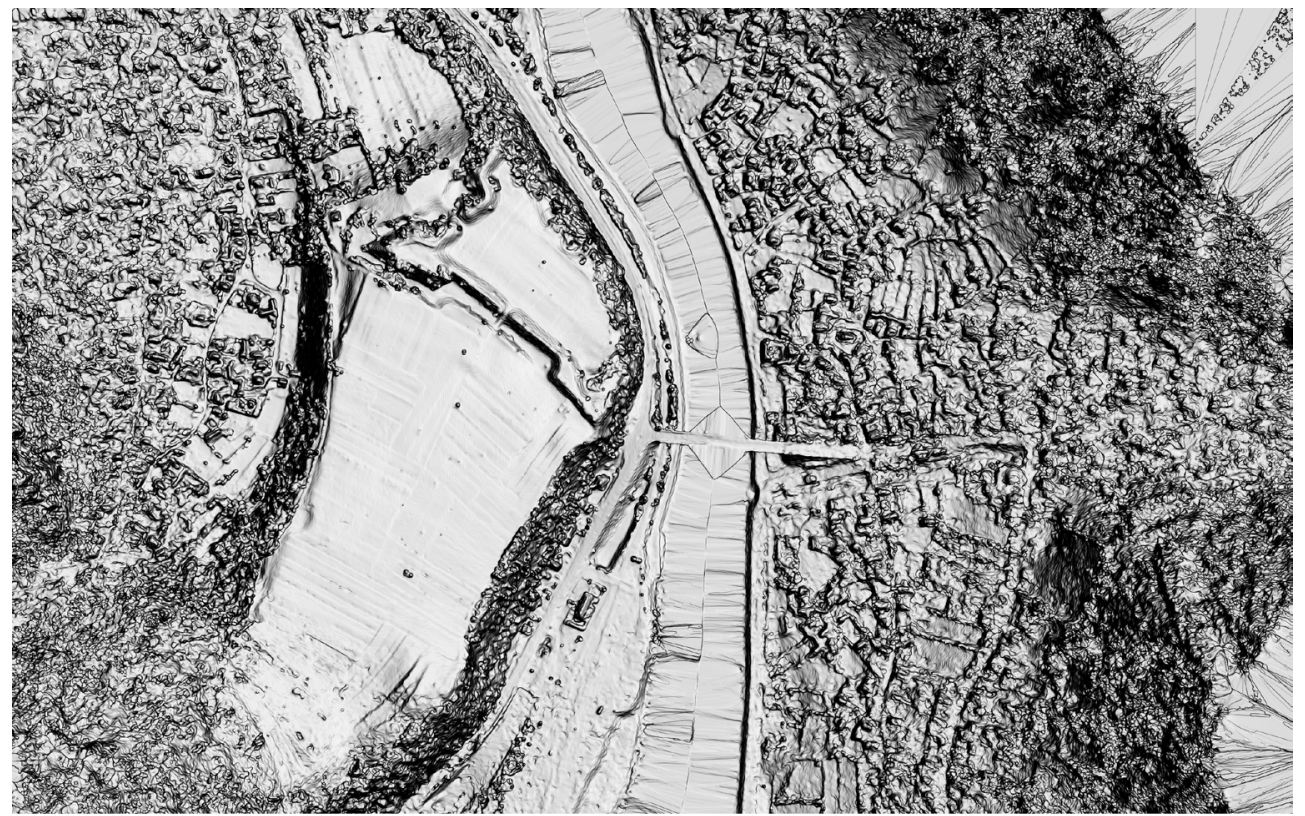




\section{Racovița (Praetorium II ? Tabula Peutingeriana VIII, 1)}

jud. Vâlcea (RAN: 172518.01.01; VL-I-m-A-09564.01)

Castrul auxiliar (fig. 8.1 - 8.6) a fost identificat pe malul stâng al Oltului, la vărsarea pârâului Clocotici în râu, pe un platou înalt, în punctul Cetate, situat la Sud-Vest de sat. La suprafața solului se conturează cu claritate sub forma unui val de formă rectangulară. O parte a zidăriei a fost conservată după terminarea săpăturilor, acum fiind cuprinsă de vegetaţie. Săpăturile arheologice au fost făcute de Cr. M. Vlădescu și Gh. Poenaru-Bordea între anii 1976-1979. Pe baza acestora a fost evidenţiată o singură fază constructivă, aparţinând castrului de piatră. Acesta are o formă rectangulară, cu colţurile rotunjite, dimensiunile fiind de $106 \times 118 \mathrm{~m}$ : Porta praetoria a fost amplasată pe latura estică. Turnurile de colț de formă trapezoidală sunt ușor ieșite spre exterior. Porțile sunt prevăzute cu turnuri patrulatere, la rândul lor, ușor ieșite în exterior. În mijlocul castrului, a fost identificată clădirea comandamentului (principia), iar în latus dextrum un horreum. Castrul datează cel mai probabil din timpul lui Hadrianus, deși sunt unele opinii potrivit cărora ar fi fost ridicat la începutul sec. III, după abandonarea fortificaţiei de la Copăceni. Nu sunt atestări ale trupei care a ocupat castrul. Este posibil să avem de-a face cu aceeaşi situație ca în cazul castrului de la Copăceni, unde epigrafic au fost documentate mai multe faze de construcție. Situația ne îndreptățește să

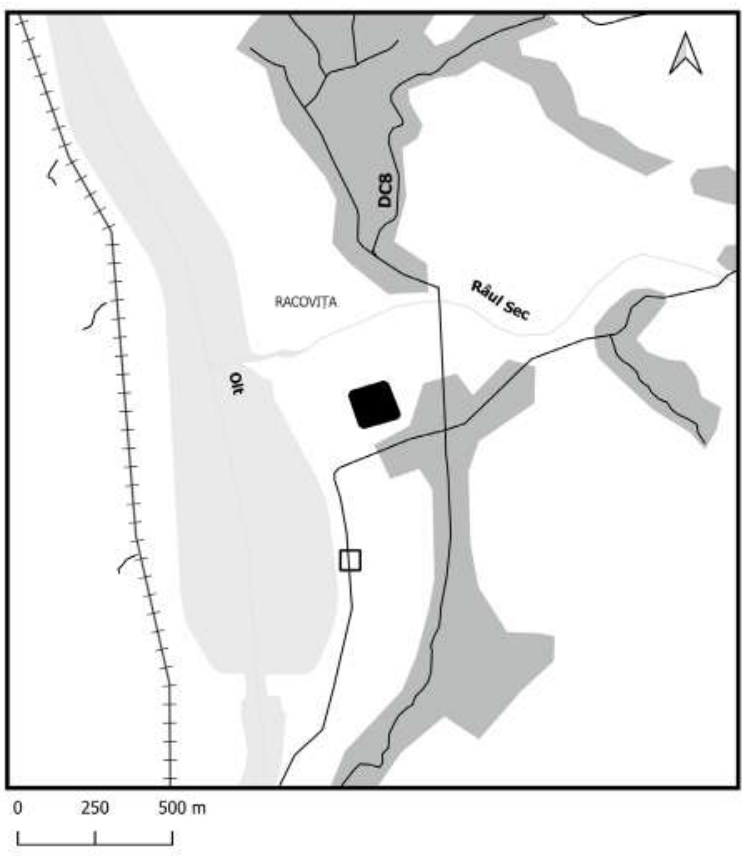

8.1. Racovița, localizarea castrului de la Racovița (poligon plin); localizarea presupusă a castrului de la Copăceni (poligon gol). subscriem ipotezei potrivit căreia, cu excepția clădirii comandamentului, celelalte clădiri din interiorul castrului au fost construite din lemn și nu au fost observate în cursul săpăturii arheologice (Bogdan-Cătăniciu 1981, 29). Așezarea civilă a fost semnalată în vecinătatea castrului prin descoperiri izolate de material arheologic.

Controlul căilor de acces era asigurat prin turnuri sau alte instalaţii militare de dimensiuni reduse. Au fost semnalate două astfel de turnuri. Turnul Piscului (?) este situat la 1,7 km Nord-Est de castrul de la Racovița; respectiv la 4,1 km, Vest faţă de Castrul de la Titești. Turnul lui Doancă este situat la aprox. 3,5 km Sud-Vest față de castrul de la Racovița. Nu se exclude posibilitatea folosirii acestuia în perioada romană, deși elementele de datare corespund sec. XIV (Vlădescu, C. M. şi Poenaru-Bordea, Gh. 1981, 348). Pe fotografii satelitare, la 1,2 km Sud-Est faţă de castrul de la Racovița, la o altitudine de 430 m, poate fi văzută o structură rectangulară (aprox. $45 \times 40$ m) care necesită efectuarea unor investigații suplimentare pentru a formula concluzii (pl.II).

Din datele publice ale proiectului de infrastructură rutieră autostrada A1 (Pitești-Sibiu), reiese faptul că acesta va afecta parțial așezarea civilă a castrului. În arealul respectiv se vor desfășura așadar cercetări arheologice preventive, care vor fi o bună oportunitate pentru cercetarea acestui obiectiv, aflat pe Lista indicativă a României pentru includerea în Lista Patrimoniului Mondial.

Bibliografie: Christescu 1937, 144-147; Tudor, D. 1941. Castra Daciae Inferioris: III. Castrul RacoviţaArgeş / Il castro romano Racoviţa-Argeş. Buletinul Comisiunii Monumentelor Istorice 34: 35-41; Tudor 1968: 372; Tudor 1978: 288-290, nr. 32; Vlădescu, C.M., Poenaru-Bordea, Gh. 1972, 27-32; Vlădescu, C.M., Poenaru-Bordea, Gh. 1974, 47-59; Vlădescu, C.M și Poenaru-Bordea, Gh. 1974a, 247-258; Vlădescu, C.M. și Poenaru-Bordea, Gh. 1980. Les deux fortifications de Praetorium sur le limes Alutanus. în: Hanson, W. and Keppie, L. (eds). Hanson, W.S. and L.J.F. Keppie (eds). Roman Frontier Studies 1979: Proceedings of the 12th International Congress of Roman Frontier Studies (British Archaeological Reports, International Series 71). Oxford: British Archaeological Reports: 815-829; Vlădescu, C.M. și PoenaruBordea, Gh. 1980. Castrele de la Praetorium din sectorul de Nord al Limesului Alutanus. Drobeta 5: 109116.; Vlădescu, C.M. și Poenaru-Bordea, Gh. 1980. Cele două castre de la Praetorium pe Limes Alutanus. Studii şi materiale de muzeografie şi istorie militară 13: 75-84; Vlădescu, C. M. şi Poenaru-Bordea, Gh. 1981. Cercetările arheologice în castrul roman de la Racoviţa, jud. Vîlcea şi în zona aferentă. Materiale şi Cercetări Arheologice 15: 345-349; Vlădescu, C. M. și Poenaru-Bordea, Gh. 1981. Castrul de la Racoviţa şi rolul său defensiv în garnizoana Praetorium. Studii vâlcene 6: 15-21; Vlădescu 1982, 55-65; Vlădescu 
1983, 108-114, nr. 19; Vlădescu, C.M. și Poenaru-Bordea, Gh.. 1983. Cercetările arheologice în castrul roman de la Racoviţa (jud. Vâlcea) şi zona aferentă. Materiale şi cercetări arheologice. A XV-a Sesiune anuală de rapoarte, Braşov, București: Editura Academiei Române: 345-349; Vlădescu 1985, 33-41; Vlădescu 1986, 70-79; Gudea 1997, 9394, nr. 82; Marcu 2009, 213-217, nr. 62.

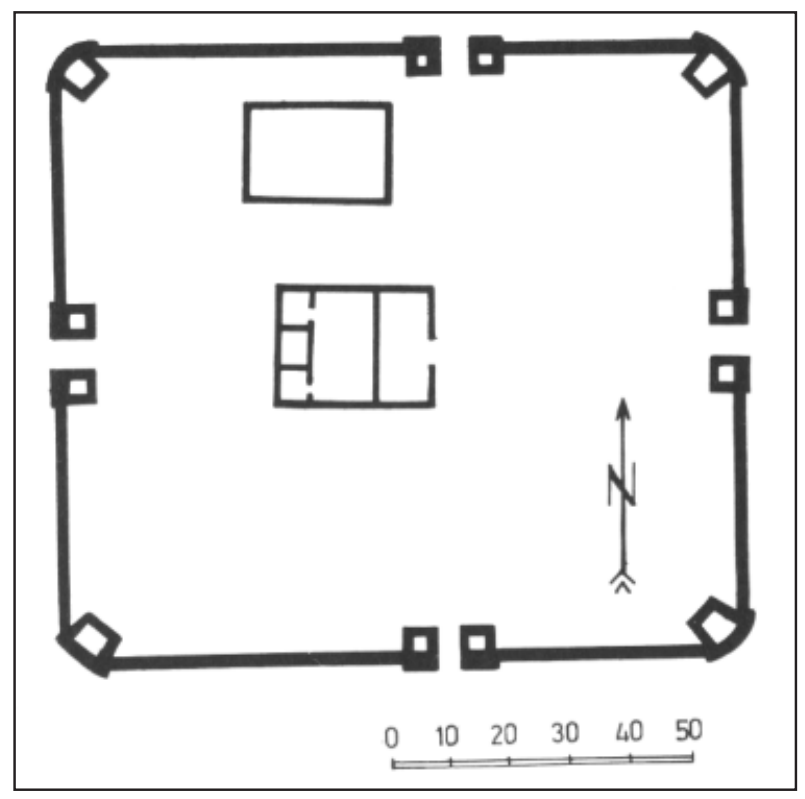

8.2. Racovița, planul castrului (Tudor 1978, 289, fig. 80).

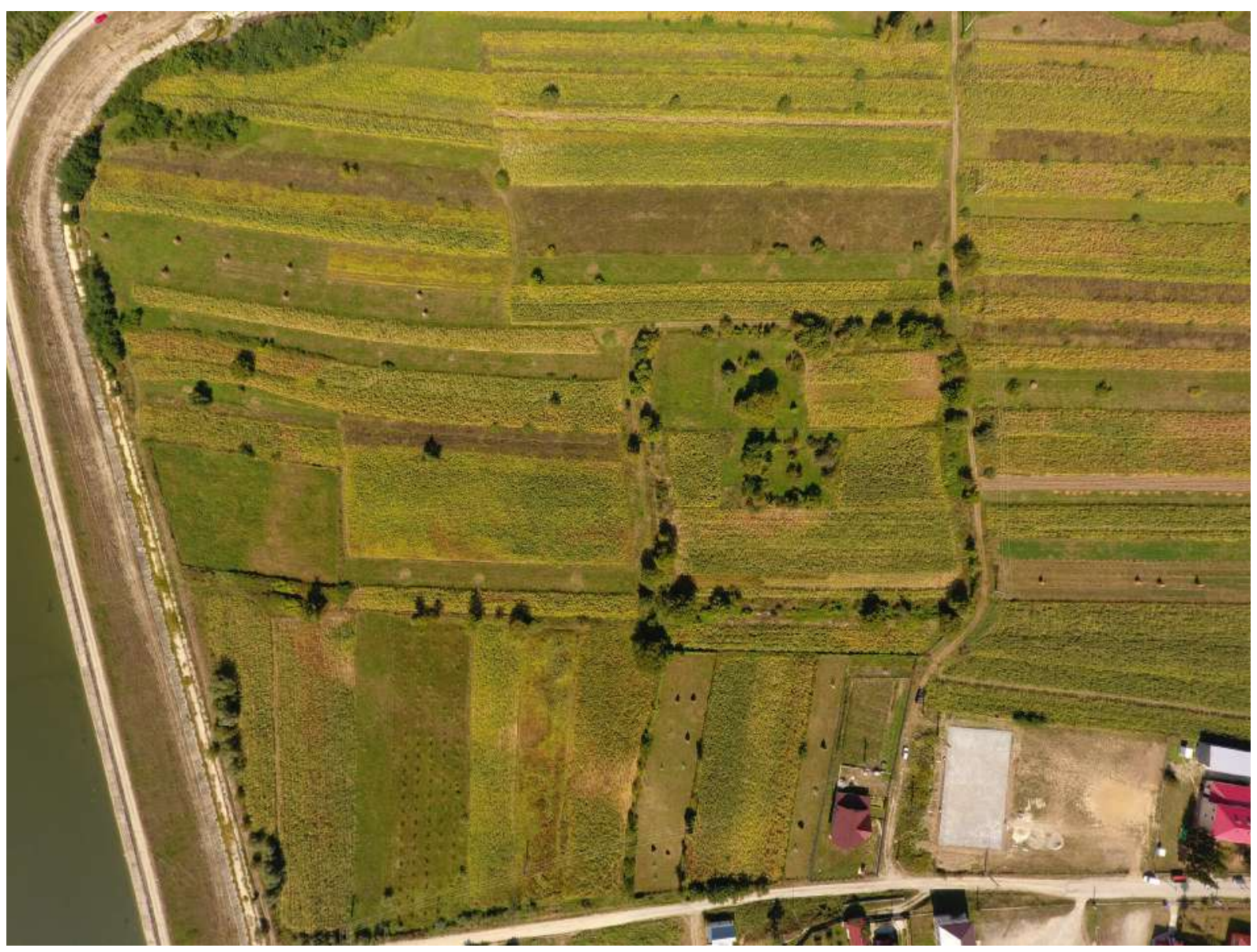

8.3. Racovița, ortofotoplan (septembrie 2016). 


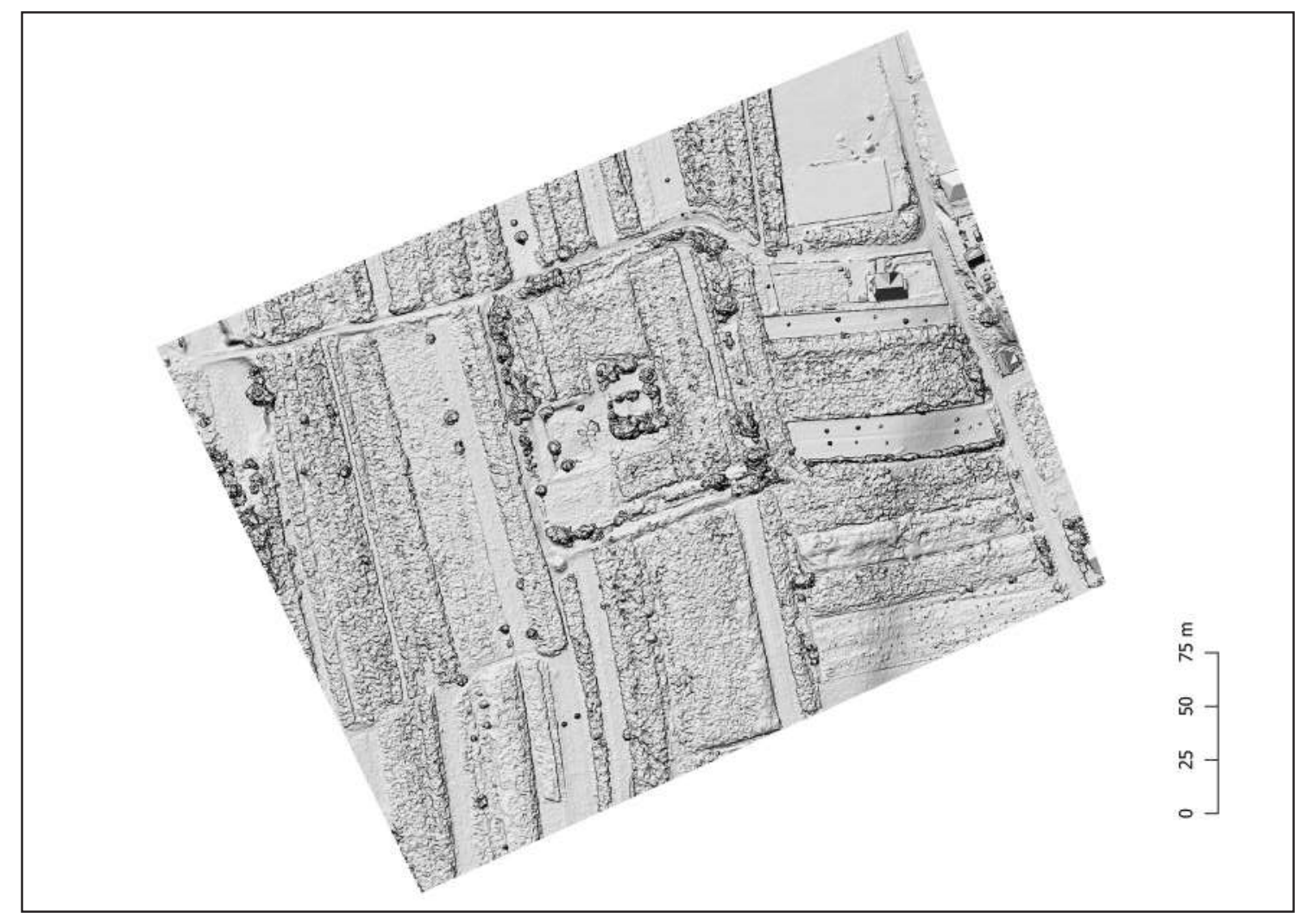

8.4. Racovița, model digital umbrit (hillshade).

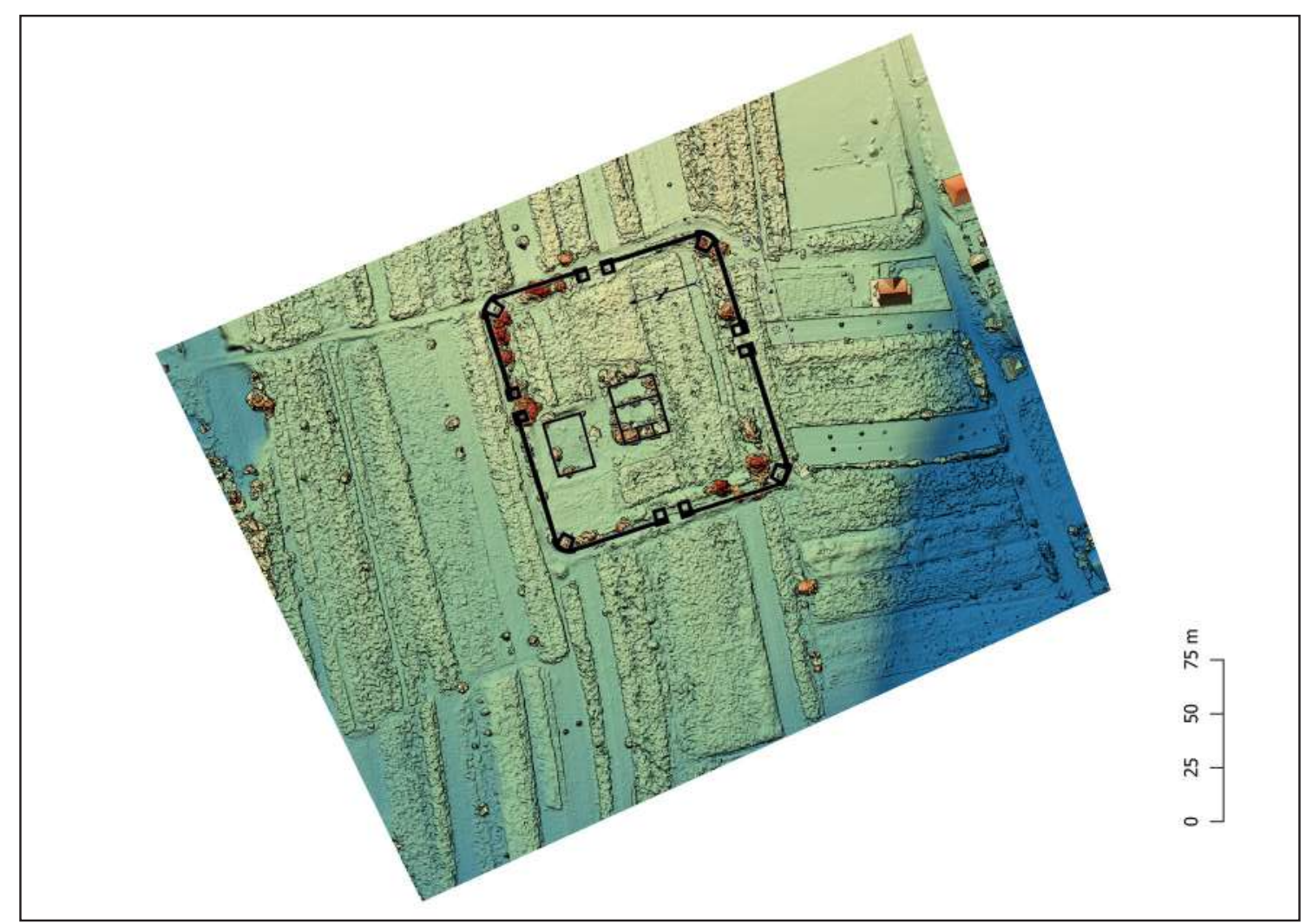

8.5. Racovița, planul castrului (Tudor 1978, 289, fig. 80) suprapus pe modelul digital al terenului. 


\section{Copăceni (Praetorium I ? Tabula Peutingeriana VIII, 1) \\ com. Racoviţa, jud. Vâlcea (RAN: 172554.01.01; VL-I-m-A-09525.01)}

Fortificația (fig. 8.1, 9.1) a fost identificată la Nord de sat, pe malul stâng al Oltului, pe o terasă înaltă, în punctul Cetate sau Seliște. Fortificația a fost distrusă în timp de apele Oltului. Partea de est a fost cercetată arheologic între anii 1973-1975 de Cr. M. Vlădescu și Gh. Poenaru-Bordea. Aceștia au documentat o singură fază de construcție. Castrul a fost construit în tehnica opus incertum, având un plan presupus pătrat cu latura de $64 \mathrm{~m}$. Turnurile de colț de formă trapezoidală erau ușor ieșite în exterior, similar celor de la poarta de pe latura estică, singura păstrată.

Informațiile epigrafice indică construirea castrului în anul 138 de către numerus burgariorum et veredariorum Daciae inferioris (CIL III 13795 = ILS 8909 = IDR II 587), fiind apoi mărit în anul 140 (CIL III 13796 = ILS 8910 = IDR II $588=$ Piso 2013, 149, nr. 6: castra n(umerus) burg(ariorum) et vered(ariorum), quod anguste tenderet, duplicato valli pede et inpositis turribus ampliavit per Aquilam Fidum, procuratorem Augusti). Se poate astfel observa că ceea ce a fost singura fază documentată arheologic reprezintă de fapt o a doua fază. Drumul de-a lungul Oltului în zona castrului de la Copăceni a fost reparat în anul 236 p. Chr. (CIL III 14216 ${ }^{19}=$ IDR II 589). Lectura unei inscripții de pe o piesă de bronz a indicat posibila prezență a unor beneficiarii consularis (CIL III 13797 = IDR II 591).

Bibliografie: Tocilescu 1900, 128-131; Wagner 1938, 204-205; TIR L 35, 35; Vlădescu și Poenaru-Bordea 1974a, 250-252; Tudor 1978, 287-288, nr. 31; Tudor, D. 1982. Materiale arheologice din castrul Praetorium I (Copăceni, jud. Vâlcea) descoperite de G. Tocilescu. Drobeta 5: 49-78; Vlădescu 1983, 106-108, nr. 18; Vlădescu 1986, 68-70; Gudea 1997, 92-93, nr. 81; Petolescu 2002, 128-129; Marcu 2009, 204-205, nr. 48; Piso 2013, 148-151, nr. 85 (C. Iulius C. f. Quir. Aquila Fidus, procurator al Daciei Inferior între anii 140142).

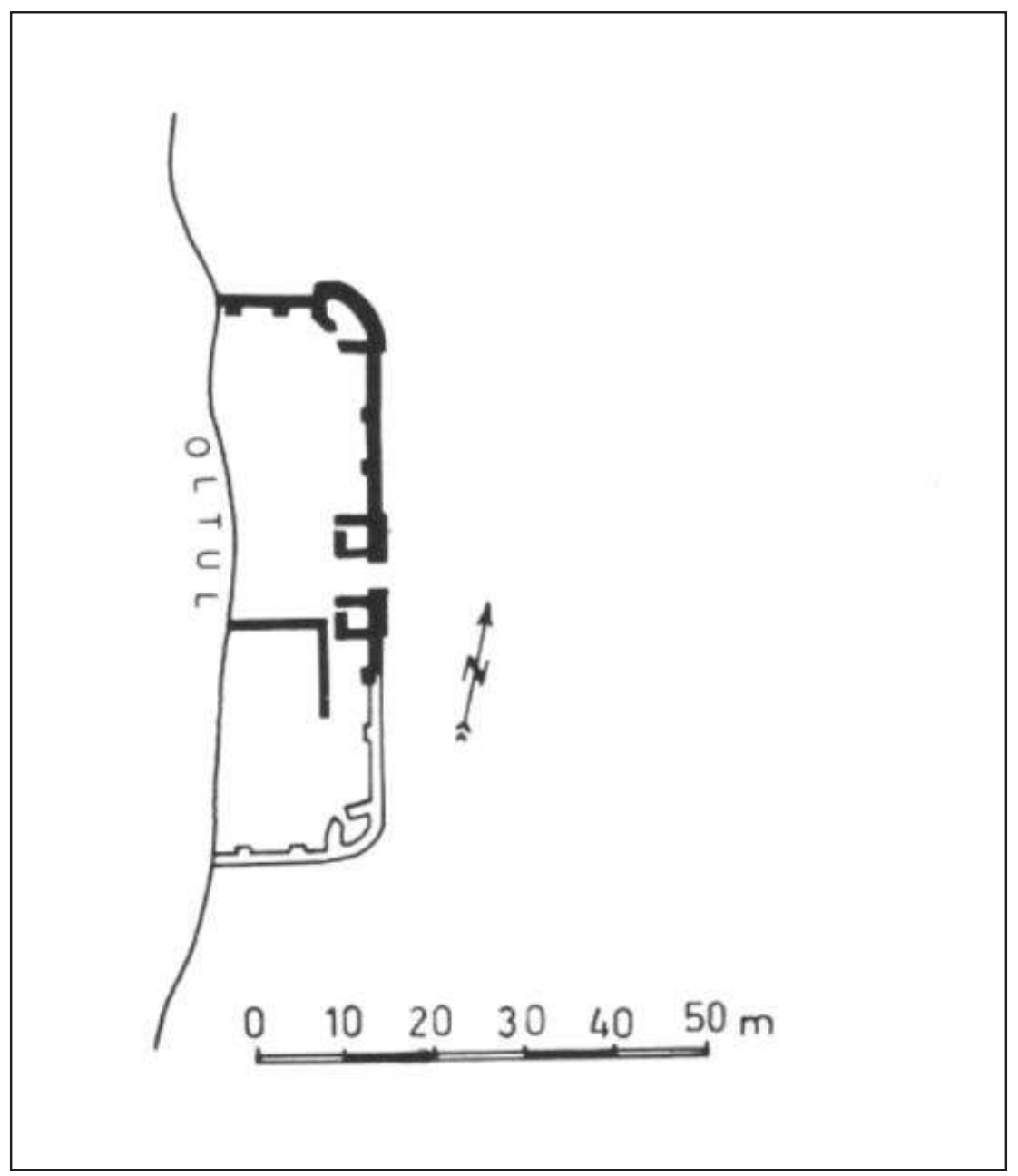

9.1. Copăceni, planul castrului (Gudea 1997, 93, nr. 81). 


\section{Titeşti}

Com. Titeşti, jud. Vâlcea (RAN 172260.01; VL-I-s-A-09587)

Fortificația (fig. 10.1 - 10.6) este amplasată pe dealul Cazanului, în apropierea locului de vărsare a pârâului Barbului în pârâul Valea Satului, în punctul Cetate, situat la $800 \mathrm{~m} \mathrm{~V}$ de satul Titești. La suprafață se poate observa o ridicătură de formă patrulateră și contururile unor săpături arheologice (Gr. Tocilescu, P. Polonic 1894; Gh. Poenaru-Bordea, Cr. M. Vlădescu 1972-1973). Raportat la situațiile precedente, a fost evidențiată o singură fază a fortificației de piatră. Incinta are dimensiunile $56,60 \times 48,20$ metri, fiind construită din piatră legată cu mortar.

$\mathrm{Au}$ fost identificate două porți de dimensiuni inegale (fig. 10.2), fără turnuri, aşezate pe laturile scurte. Porta praetoria este pe latura estică. În interior a fost identificată clădirea comandamentului (principia), care avea dimensiuni neobișnuit de mici $(5,50 \times 9,50 \mathrm{~m})$. Datarea construirii s-a făcut prin analogii cu castella învecinate, de la Copăceni (Praetorium I), Arutela şi Rădăcineşti, probabil în epoca lui Hadrianus.

Bibliografie: TIR L 35, 71; Tudor 1968, 371; Vlădescu, C.M., Poenaru-Bordea, Gh. 1972, 27 32; Vlădescu, C.M., Poenaru-Bordea, Gh. 1972, 3: 27-32; Vlădescu, C.M., Poenaru-Bordea,

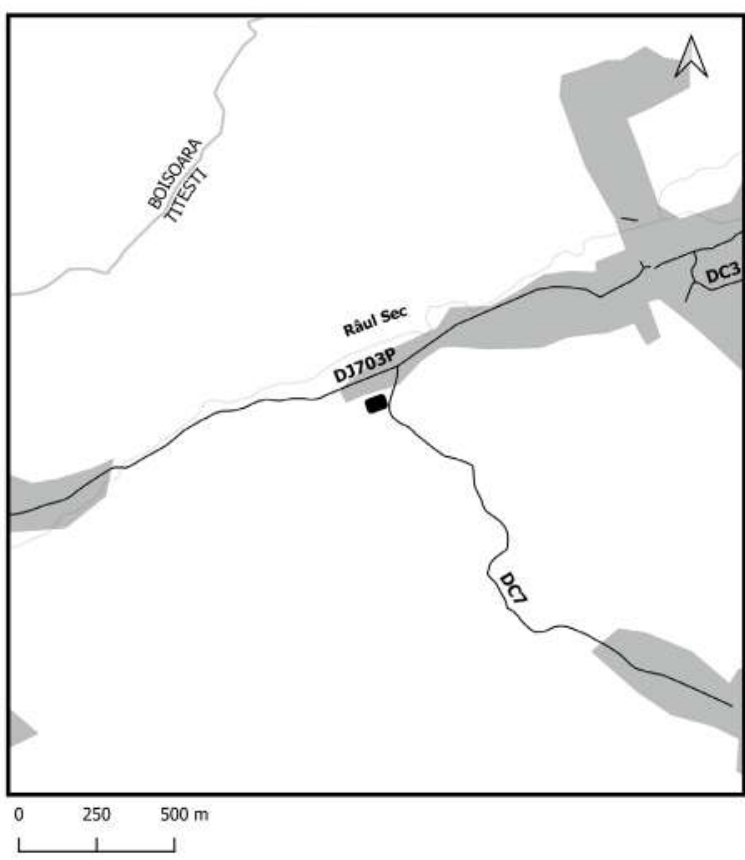

10.1. Titești, localizarea castrului.. Gh. 1974, 47-59; 257-258; Vlădescu, C.M și Poenaru-Bordea, Gh. 1974a, 247-258; Vlădescu 1982, 55-65; Vlădescu 1985, 33-41; Tudor 1978, $307-$ 308, nr. 48; Vlădescu. C. M., Poenaru-Bordea, Gh. și Stoica, O. 1979. Studii şi materiale de muzeografie şi istorie militară 12: 124-149; Poenaru-Bordea, Gh. Și Vlădescu, C. M. 1981. Castrul de la Titeşti com. Perşani, jud. Vâlcea. Studii și Cercetări de Istorie Veche şi Arheologie 32, 4: 581-591; Vlădescu 1983, $104-$ 106, nr. 17; Vlădescu 1986, 65-67; Gudea 1997, 92, nr. 80; Marcu 2009, 243-245, nr. 74.

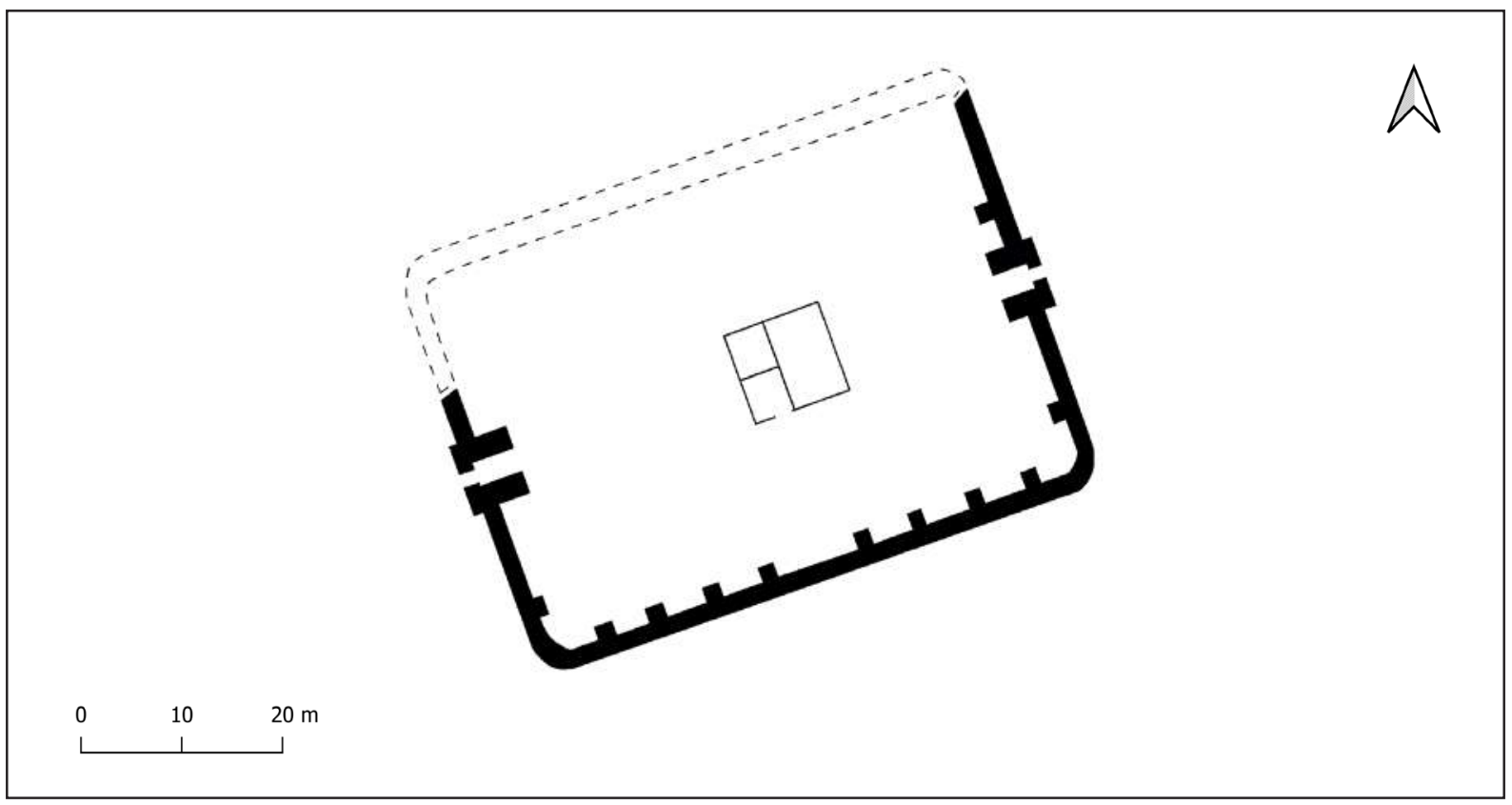

10.2. Titești, planul castrului (reconstituire după Tudor 1978, 287, fig. 79/4). 


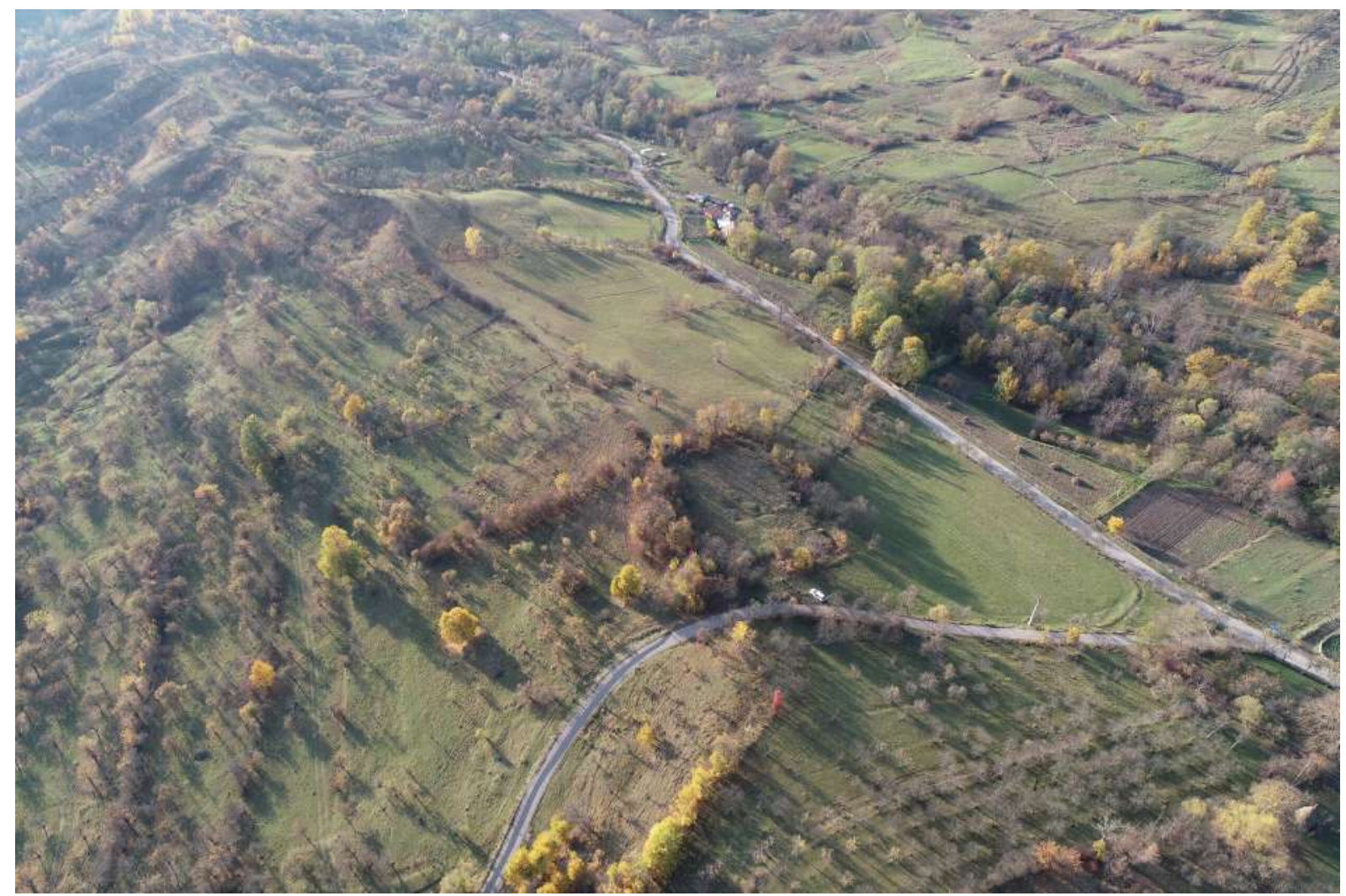

10.3. Titești, fotografie oblică din dronă, vedere dinspre Sud-Est (noiembrie 2020).

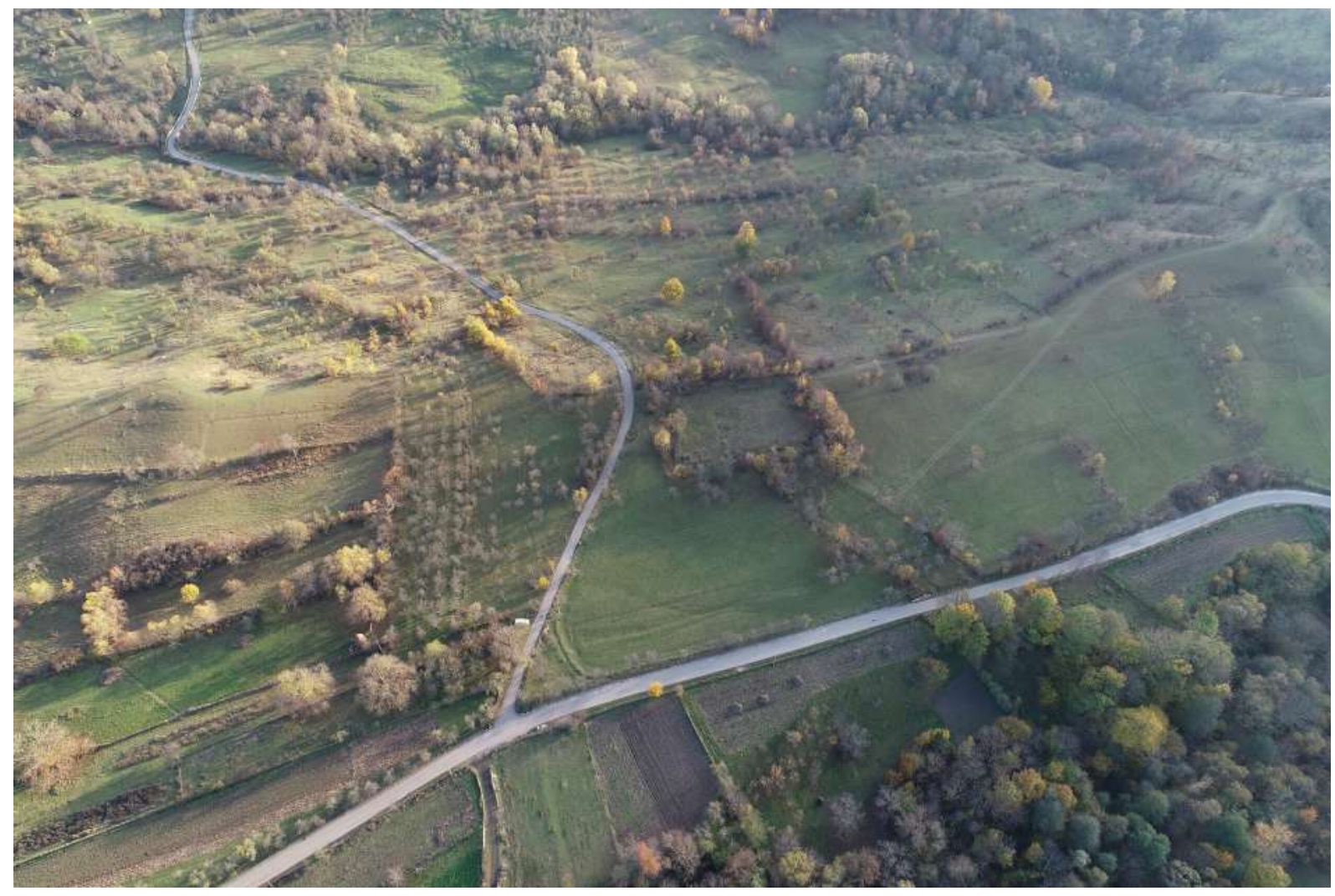

10.4. Titești, fotografie oblică din dronă, vedere dinspre nord (noiembrie 2020). 


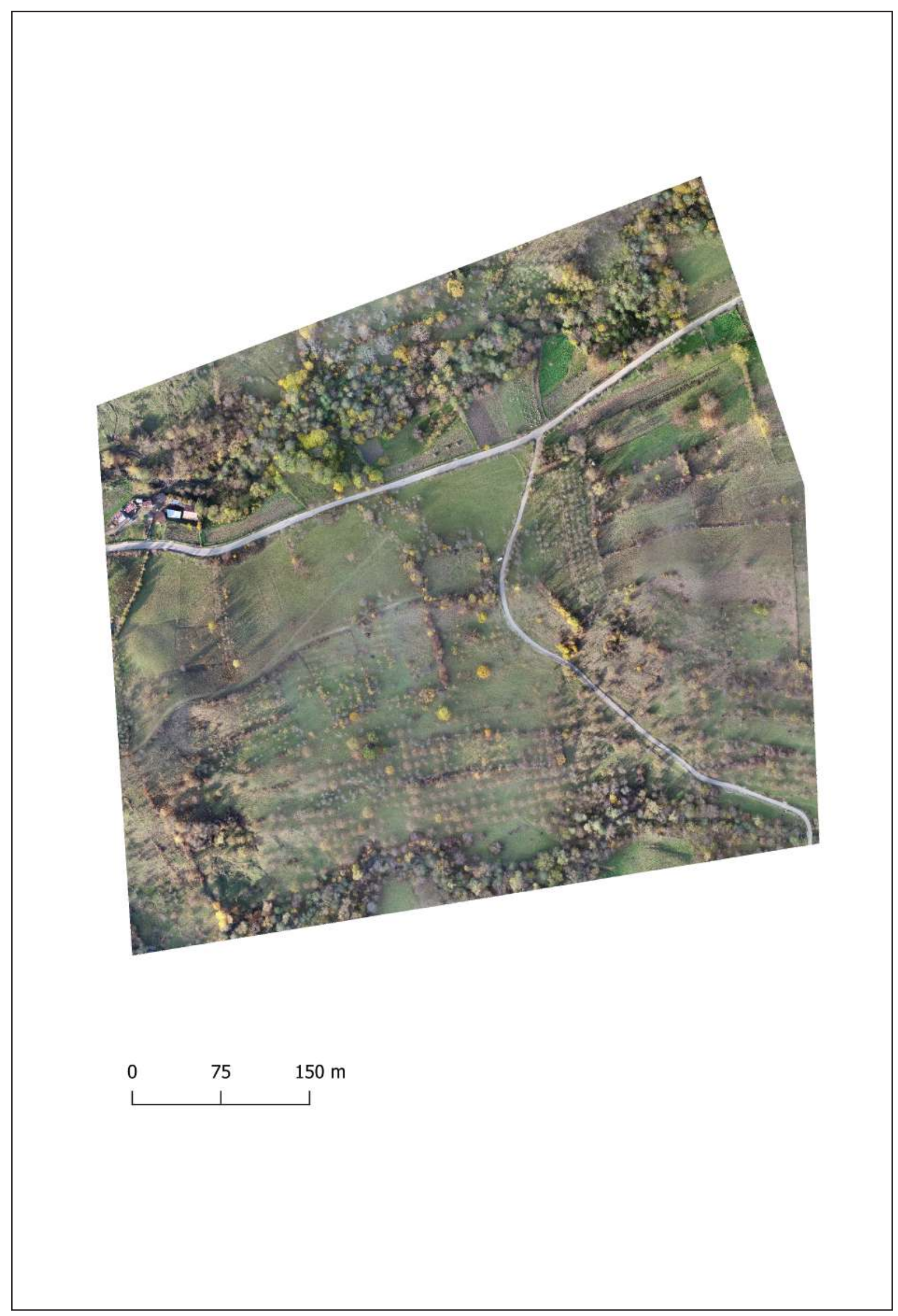

10.5. Titești, ortofotoplan dronă. 

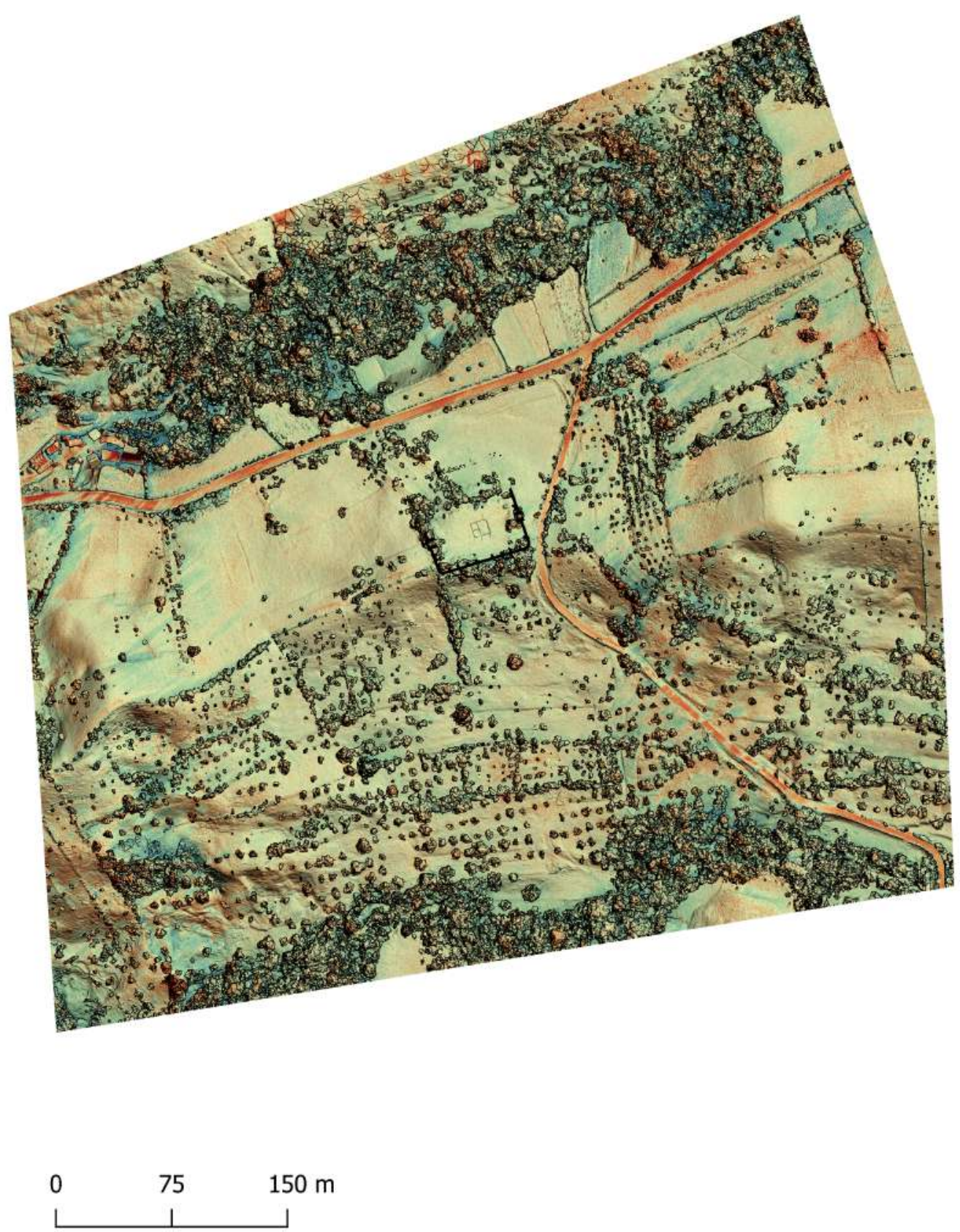

10.6. Titești, planul castrului (reconstituire după Tudor 1978, 287, fig. 79/4) suprapus pe modelul digital al terenului. 


\section{Pripoare}

Com. Perișani, jud. Vâlcea

La trei km spre Sud de Perişani (fig. 11.1 - 11.5), la capătul sudic al cătunului Pripoare, „tocmai în defileu, pământul acoperă astăzi zidurile unei vechi cetăți de circa 60 metri lungime și 40 - 45 de metri lăţime « Zid gros, fãcut din piatră cu var... peste drum de tăpșanu unde era cârciuma veche din Pripoare; au scos oamenii piatră de acolo, poate o sută de care » (declarațiile unor săteni din Perișani, azi 20 Sept. 1933; zidurile, însă, leam văzut noi înșine)". (Conea 1935, 92, nota 1). Ion Conea era de părere că ,urmele de puternică cetate de la Perișani sunt tot ale unui castru roman”.

Bibliografie: Conea 1935, 92, nota 1.

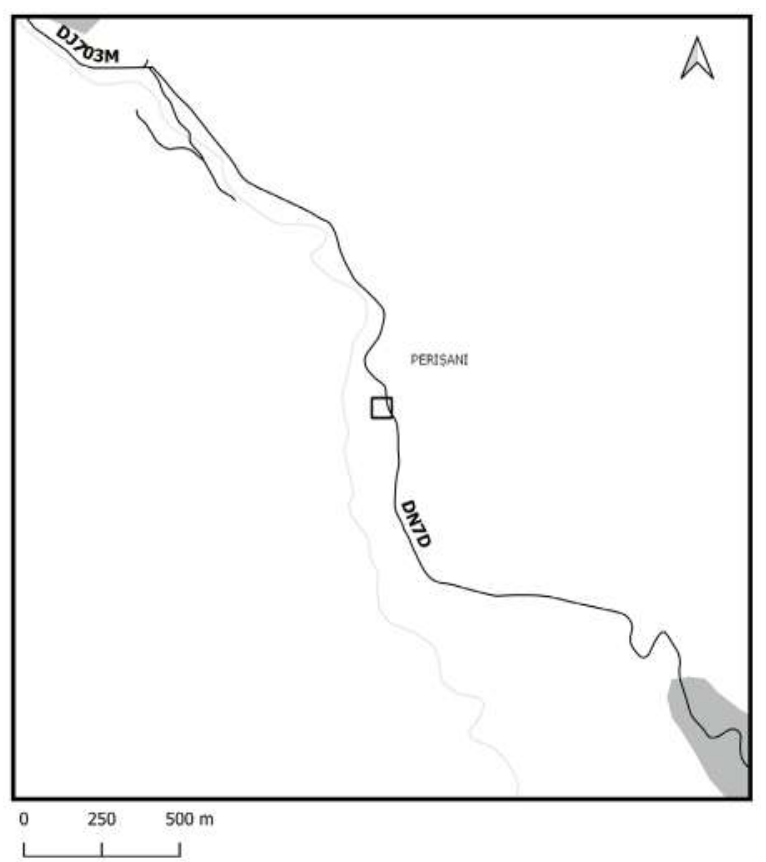

11.1. Pripoare, localizarea presupusă a castrului.

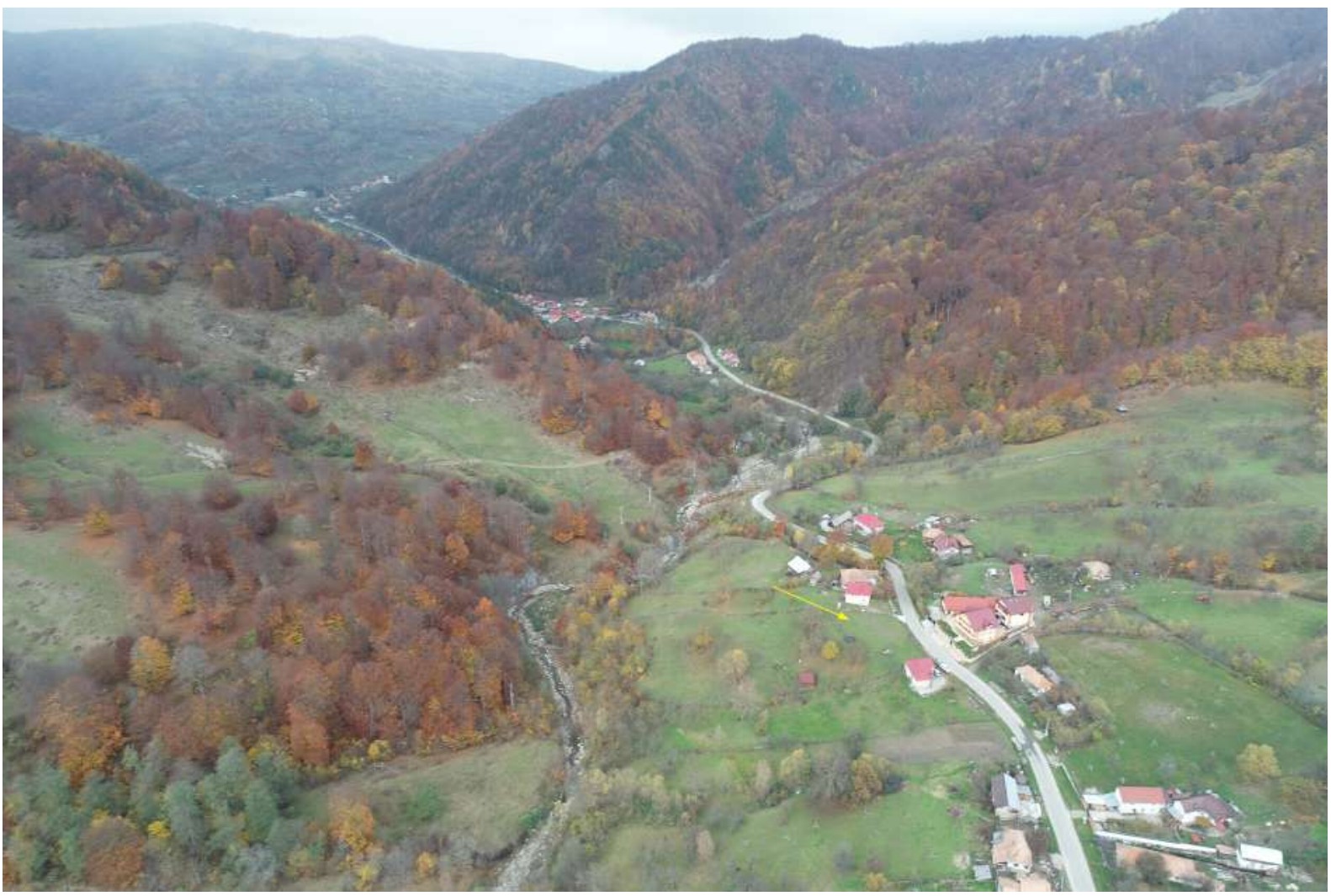

11.2. Pripoare, fotografie oblică din dronă, vedere dinspre Sud (noiembrie 2020). 


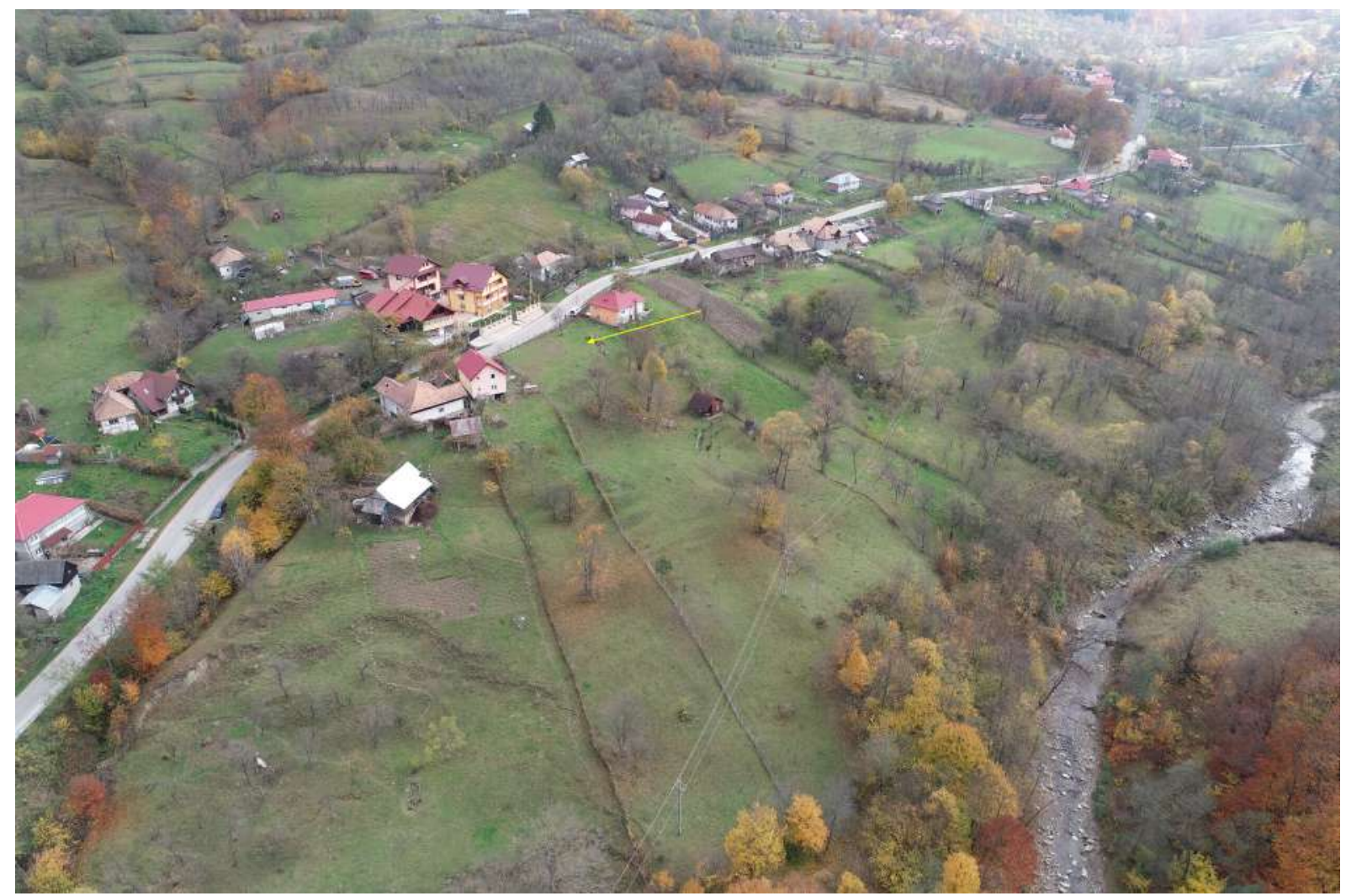

11.3. Pripoare, fotografie oblică din dronă, vedere dinspre Nord-Vest (noiembrie 2020).

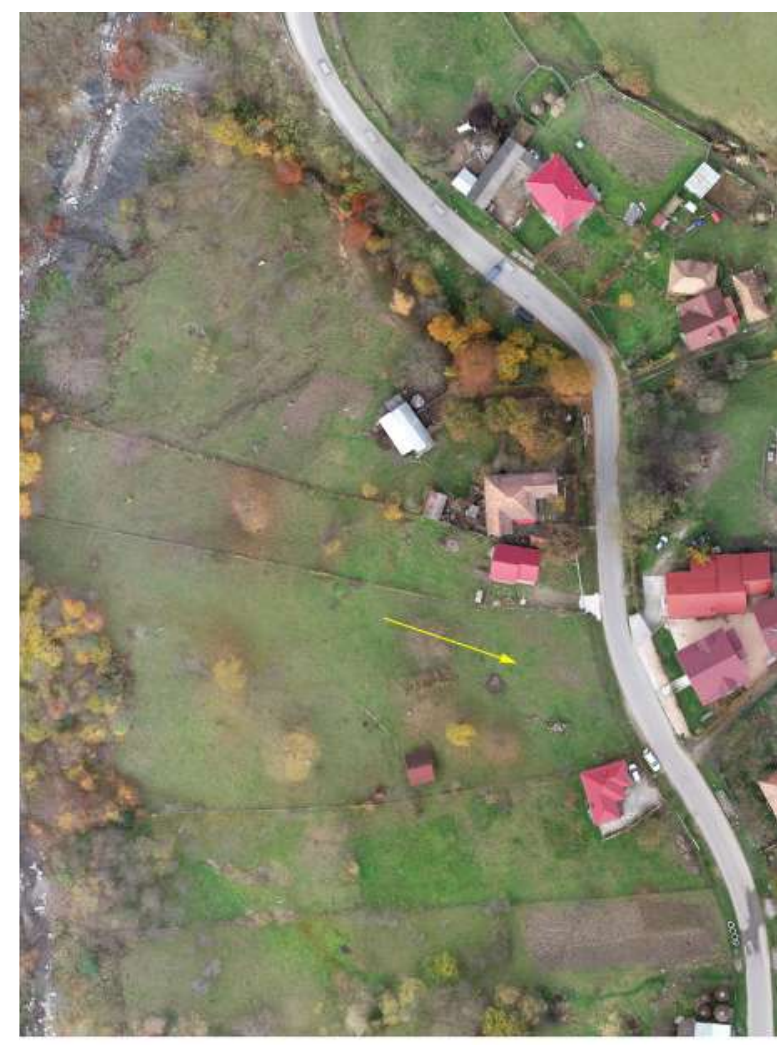

$0 \quad 10 \quad 20 \quad 30 \mathrm{~m}$

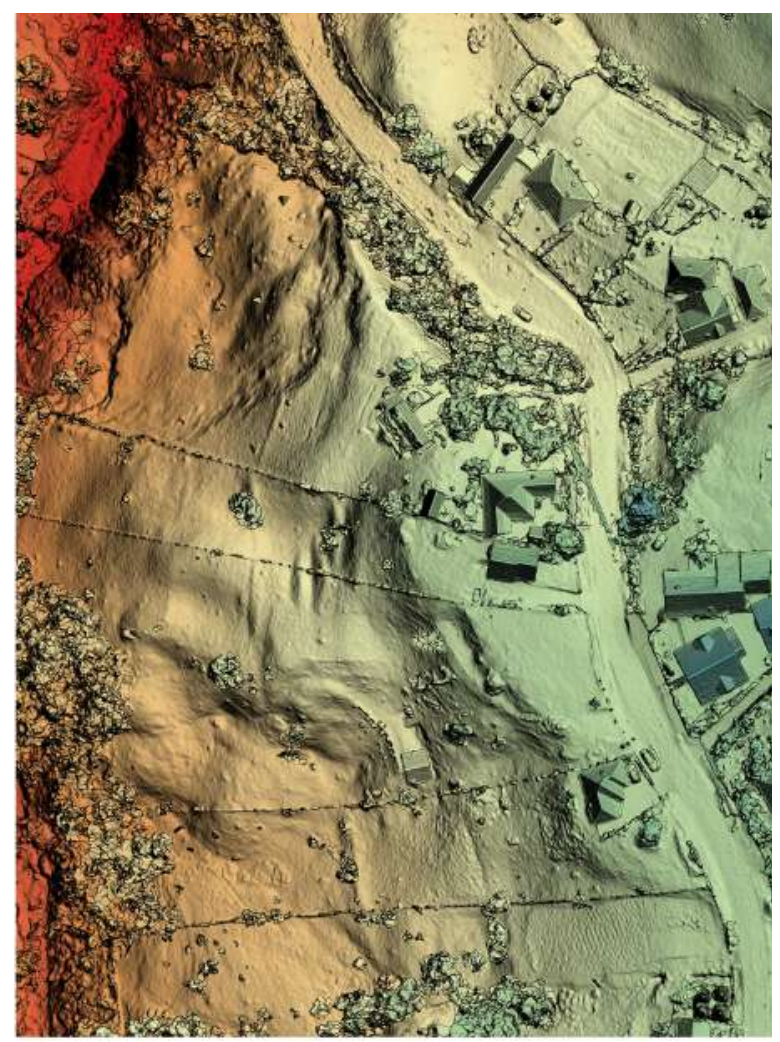

$0 \quad 10 \quad 20 \quad 30 \mathrm{~m}$

11.5. Pripoare, model digital al terenului. 


\section{Rădăcinești}

Com. Berislăveşti, jud. Vâlcea ( RAN: 168728.01; VL-I-s-B-09565)

Situat în jumătatea nordică a satului (fig. 12.1 - 12.7), în punctul „Cetate”; puțin cercetat, Cr. M. Vlădescu, Gh. Poenaru Bordea 1971-1975. A fost evidențiată o singură fază: castellum de piatră cu formă rectangulară, având dimensiunile de $54,60 \times 56,70 \mathrm{~m}$, orientat Nord-Sud; zid de piatră, construit în tehnica opus incertum, de 1,60 m grosime; turnuri de colț de formă trapezoidală; au fost identificate porți pe laturile de $\mathrm{S}$ și E, cu deschideri de $3,40 \mathrm{~m}$ în interior au fost semnalate urme ale clădirii comandamentului (principia); două inscripții de construcție din anul 138 p. Chr., care atestă prezența unui (numerus) Syrorum sagittariorum - Suri sagittarii, însă întregit pe baza inscripțiilor din castrul de la Bivolari, v. mai jos (CIL III 12604 = IDR II 584; CIL III 12605 = IDR II 585 - [Suri? sag]ittarii).

Bibliografie: Tocilescu 1900, 135, nr. 3; Christescu 1937, 199; Tudor 1968, 371; TIR L 35, 60; Vlădescu, C. M. și Poenaru Bordea, Gh. 1972. Primele săpături arheologice în fortificaţia romană de la Rădăcineşti. Studii şi cercetări de istorie veche 23: 447-486; Vlădescu, C.M și Poenaru-Bordea, Gh. 1974a, 250-253; Tudor 1978, 294-297, nr. 37; Vlădescu 1983, 101-104, nr. 16; Vlădescu, C.M. 1982. 55-65; Vlădescu, C.M. 1985, 33-41; Vlădescu 1986, 62-65; Gudea 1997, 90-91, nr. 77; Marcu 2009, 221-222, nr. 64.

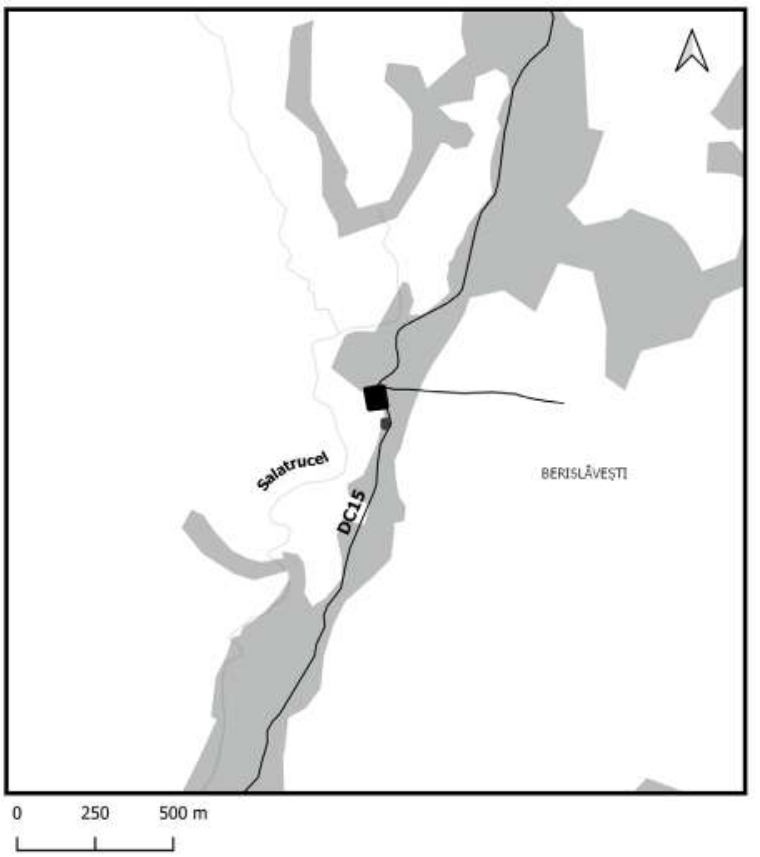

12.1. Rădăcinești, localizarea sitului și a băilor.
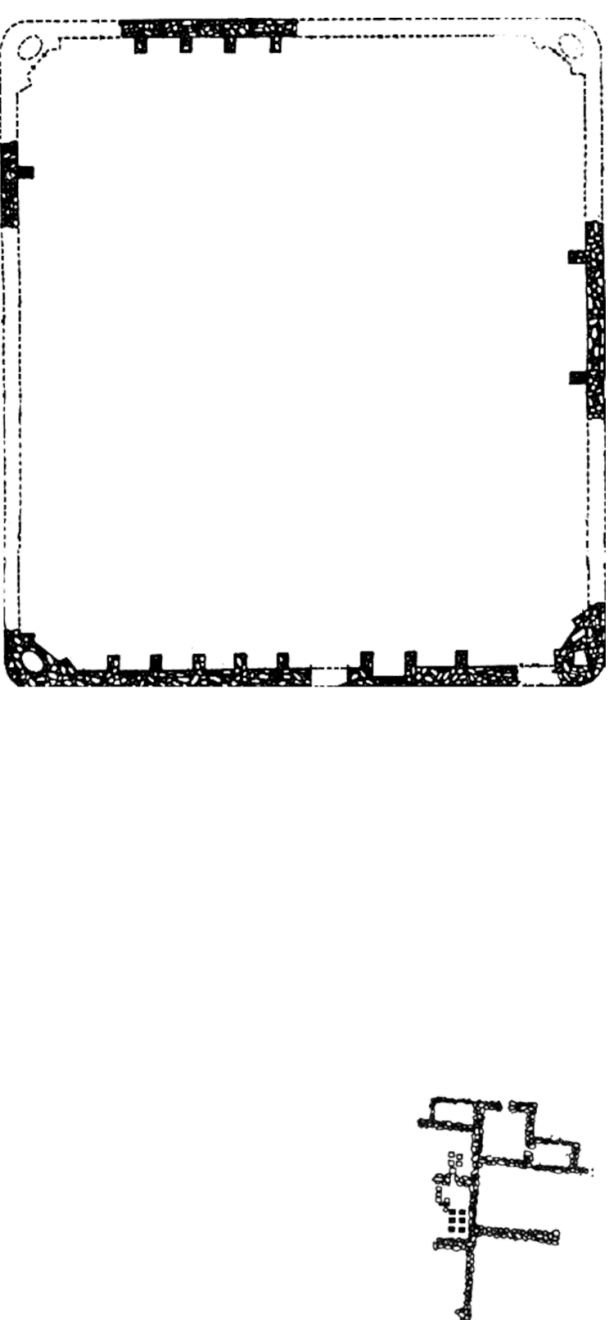


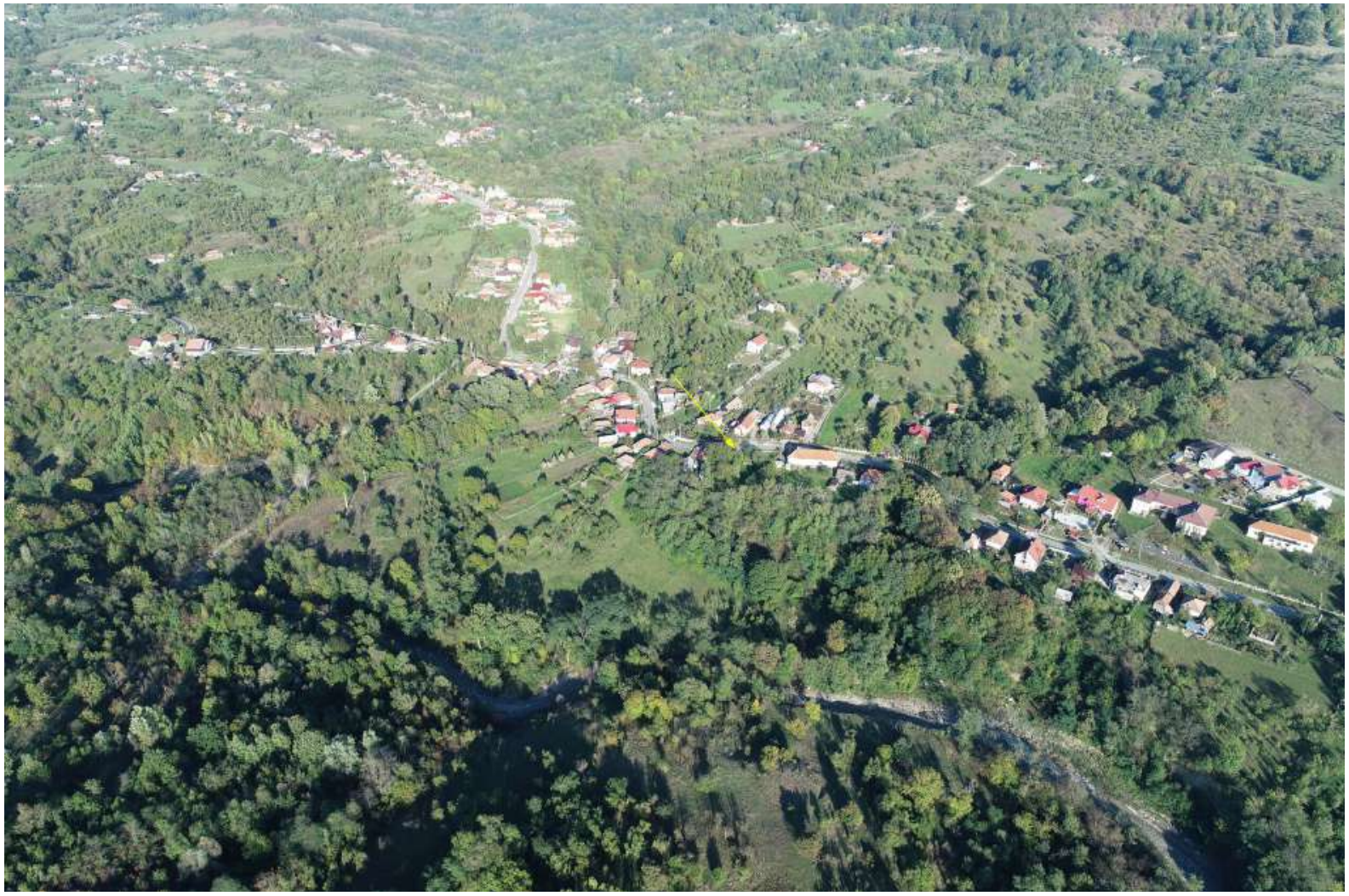

12.3. Rădăcinești, fotografie oblică din dronă, vedere dinspre Sud-Vest (octombrie 2020).

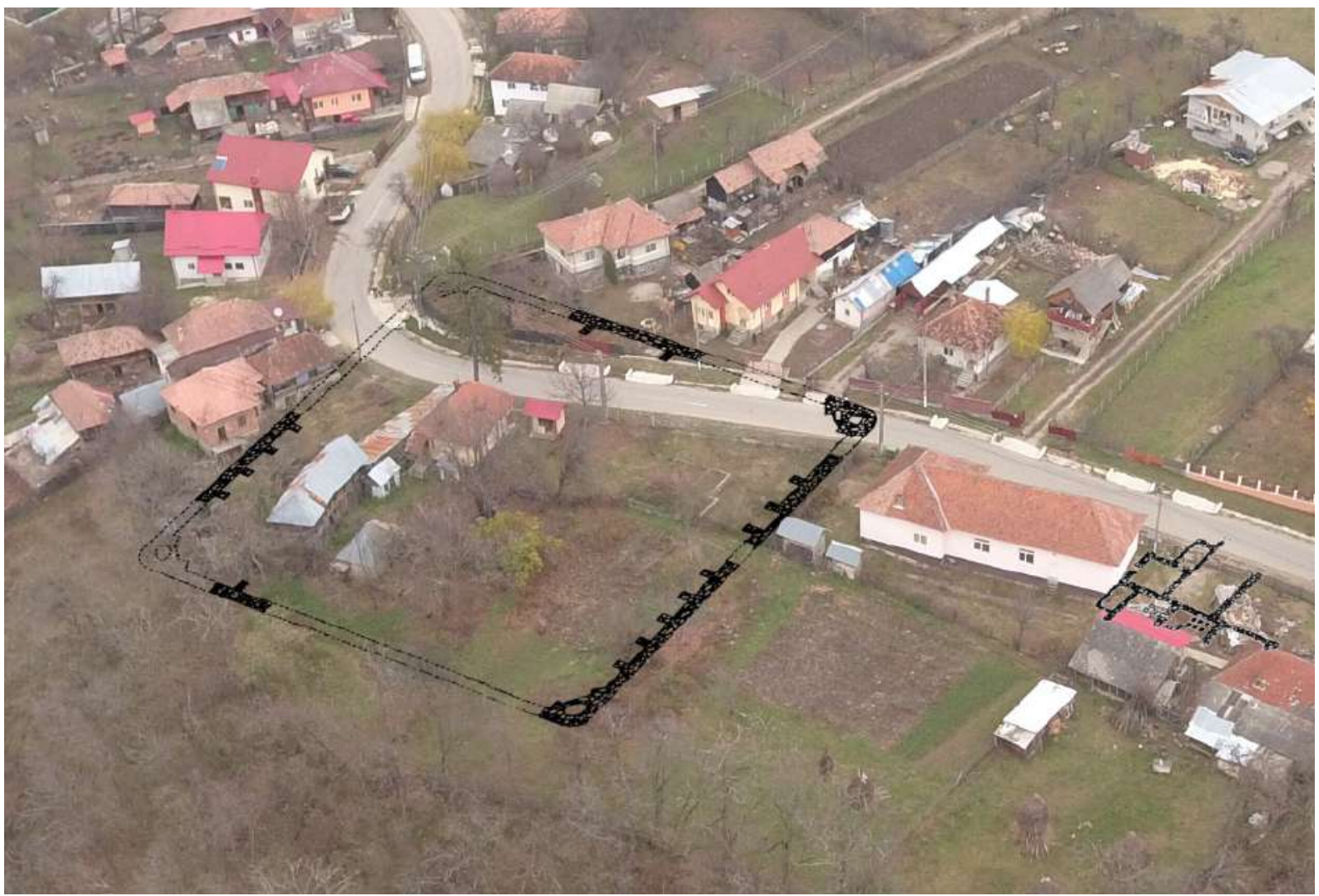

12.4. Rădăcinești, planul sitului (Bogdan-Cătăniciu 1997, fig. 42) suprapus pe o fotografie oblică din dronă, vedere dinspre Sud-Vest (octombrie 2020). 


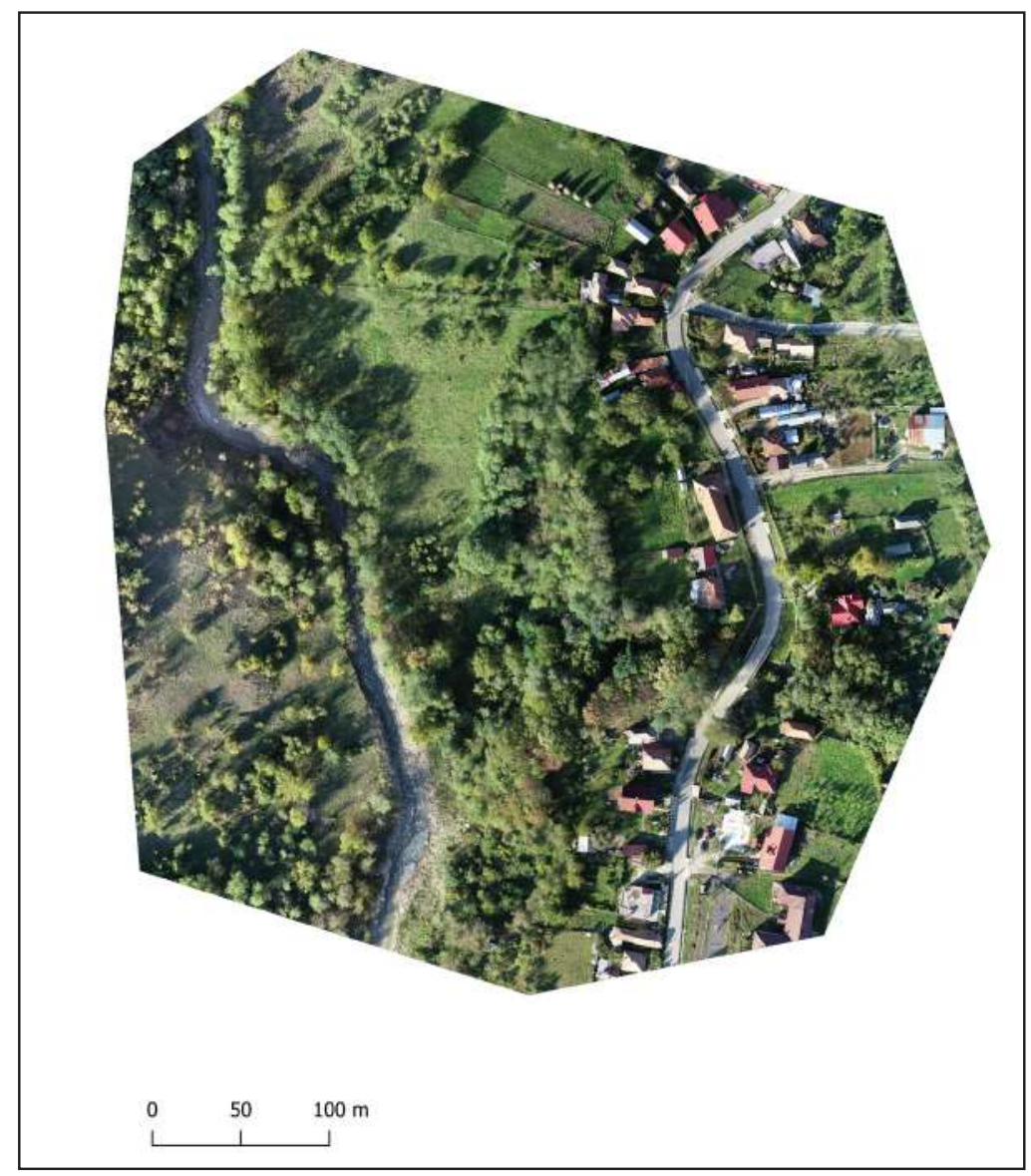

12.5. Rădăcinești,

ortofotoplan dronă.

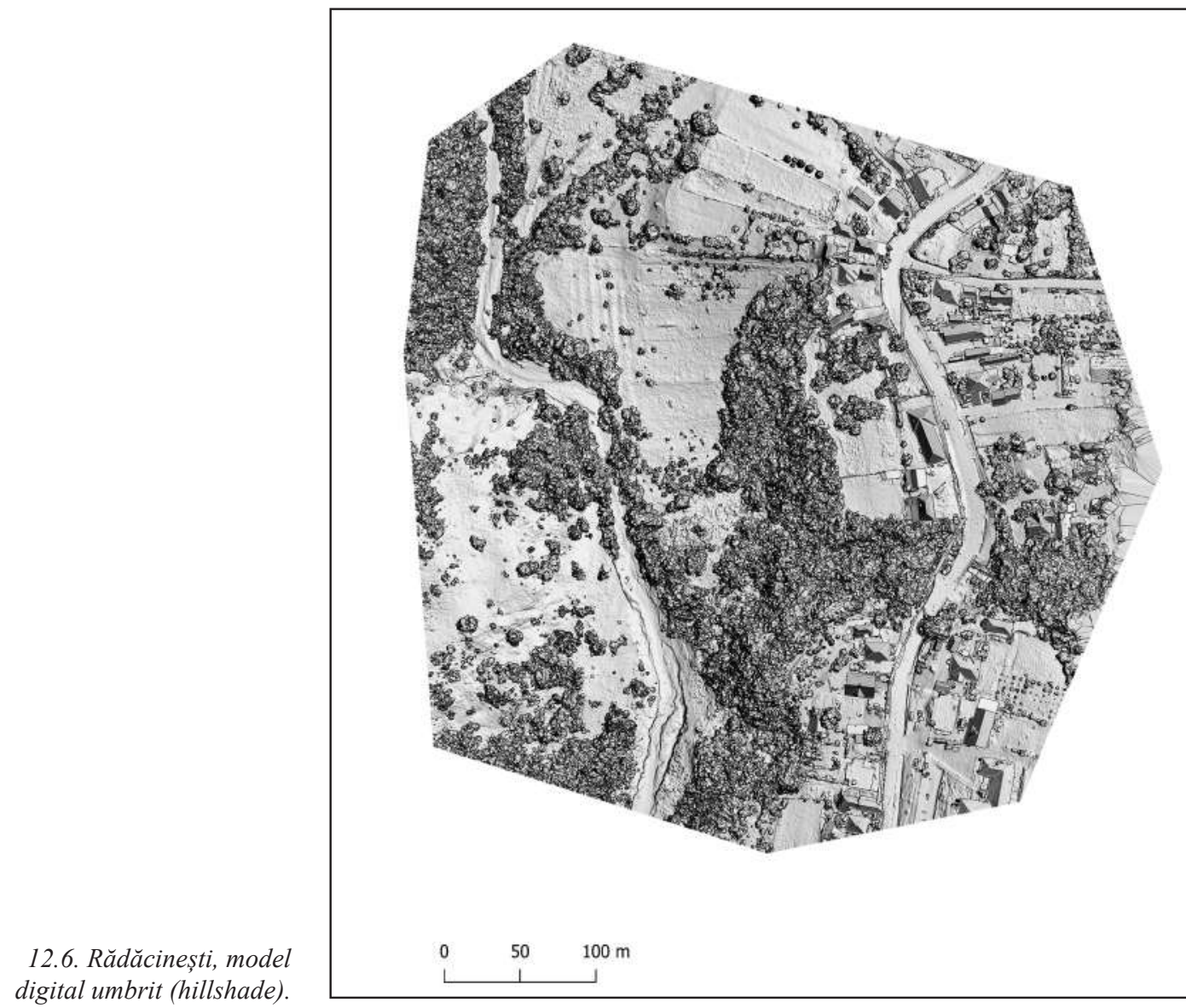




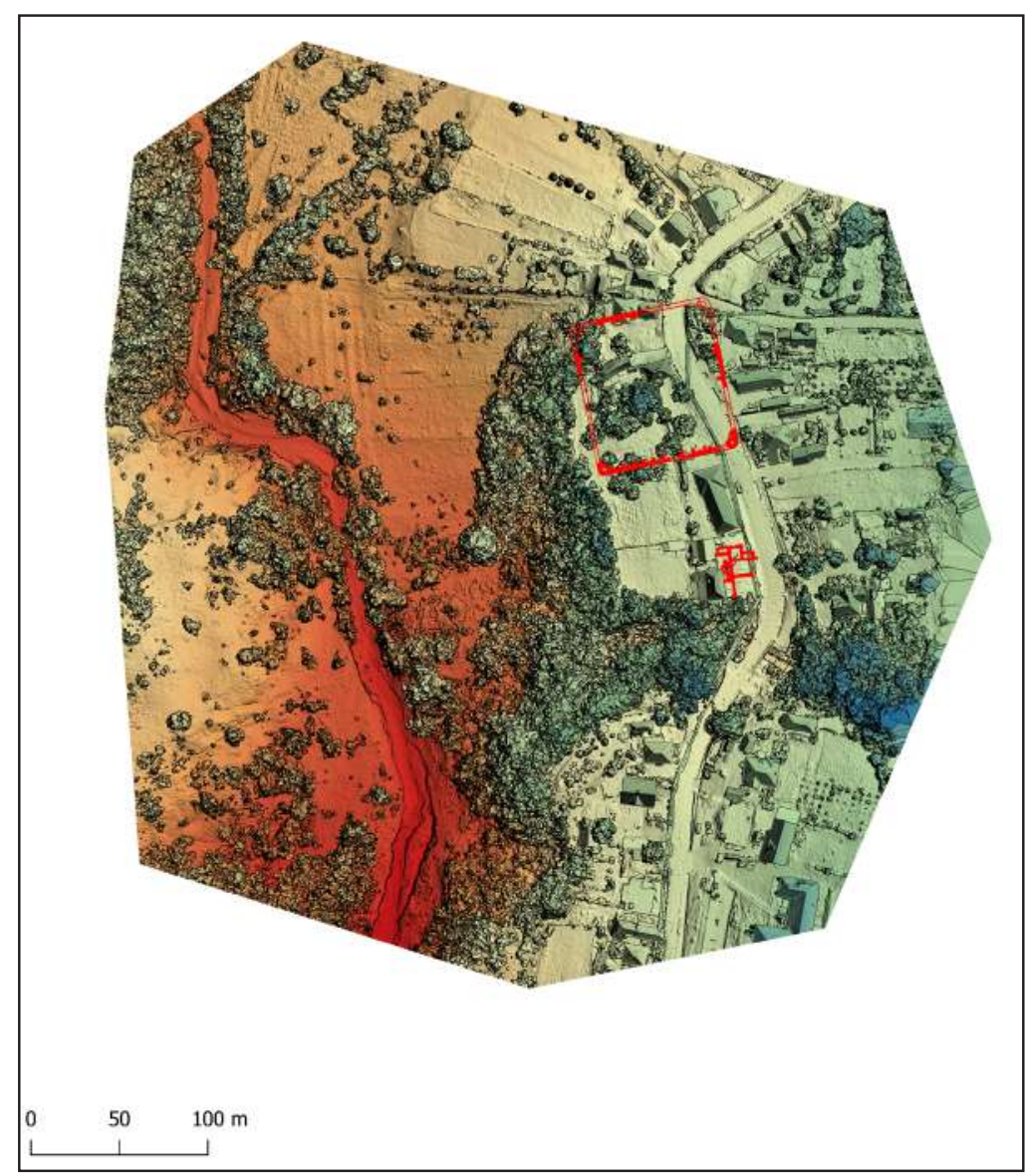

12.7.

Rădăcinești,

planul castrului

(reconstituire

după Bogdan-

Cătăniciu

1997, fig. 42)

suprapus pe

modelul digital

al terenului.

\section{Văratica}

Com. Brezoi, jud. Vâlcea (RAN: 167883.01)

Turnul de la Văratica (fig. 13.1, pl. II) era amplasat pe malul stâng al Oltului, în apropierea confluenței dintre râurile Lotru și Olt, pe un platou înalt de circa 20 - 30 m, aflat la Sud de biserica satului. Fortificația era situată între Racovița $(12 \mathrm{~km})$ și Călimănești (16 $\mathrm{km}$ ), având rolul de a supraveghea valea Oltului într-un punct intermediar, situat la confluența cu un afluent. Astăzi este acoperit de construcții moderne.

Turnul are forma pătrată, cu latura de $10 \mathrm{~m}$ și are ziduri de piatră, groase de $1,10 \mathrm{~m}$, păstrate pe o înălțime maximă de 1,60 m (Vlădescu 1986, 67, fig. 60). Fundația a fost construită din pietre de râu și pietre de carieră legate cu mortar.

Pe baza materialul arheologic descoperit s-a putut argumenta funcționarea clădirii pe durata secolului III p. Chr.

Bibliografie: Tudor 1978, 233; Vlădescu 1986, 66-67; Vlădescu, C.M. și Stoica, O. 1985: $O$ fortificaţie romană necunoscută la Văratica (Brezoi, jud. Vâlcea). Studii şi Materiale de muzeografie şi istorie militară 17-18: 137-143.

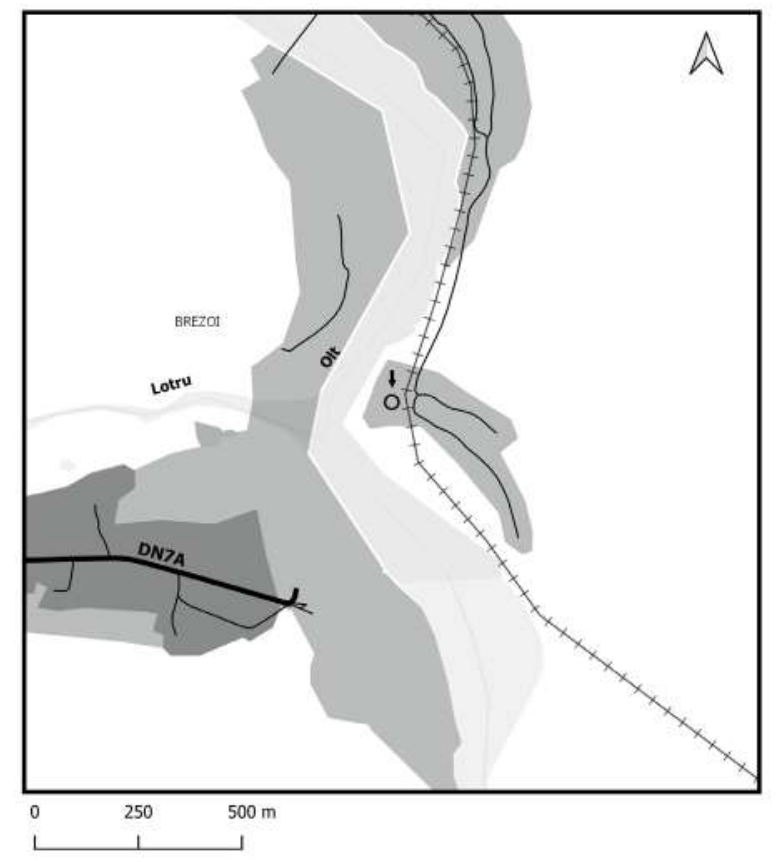

13.1. Localizarea presupusă a turnului de la Văratica. 
14. Călimăneşti, fost Bivolari (Arutela, Tabula Peutingeriana VIII, 1), jud. Vâlcea (RAN: 167954.01; VL-I-s-A-09562)

Fortificația (fig. 14.1 -14.10) a fost identificată pe terasa de pe partea stângă a râului, în punctul „Bivolărie” sau „Poiana Bivolari”, situat în vecinătatea Mânăstirii Cozia. Astăzi se află pe teritoriul orașului Călimănești. Castrul avea probabil o formă pătrată $(60,40 \mathrm{~m} \times$ 46,40/41,40 parțial), având porta praetoria către Est, anume către drum.

Primele informaţii despre ruinele castrului datează din 1888 , prilej cu care s-au descoperit cele două inscripții. Ulterior amatorii de antichități au distrus o parte din ruine. În anii 1891 şi 1892, P. Polonic a săpat în întregime termele şi parțial castrul (laturile de Est, de Nord și câteva sondaje în interior). Rapoartele de săpătură şi schițele întocmite de Polonic s-au păstrat numai parțial în manuscrisul Tocilescu (Biblioteca Academiei R.S.R., vol. 5 133, p. 95-104 cf. Tudor 1942, 143). Între anii 1897-1902, castrul a fost parțial acoperit ca urmare a construirii căii ferate Râmnicu Vâlcea - Râul Vadului, prilej cu care băile, parțial afectate de cursul Oltului, au dispărut în întregime.

Săpăturile arheologice au fost reluate între anii 1967 - 1970, respectiv 1978. Acestea au fost concentrate în partea vestică a castrului, unde a fost dezafectată calea ferată construită în urmă cu șapte decenii în vederea

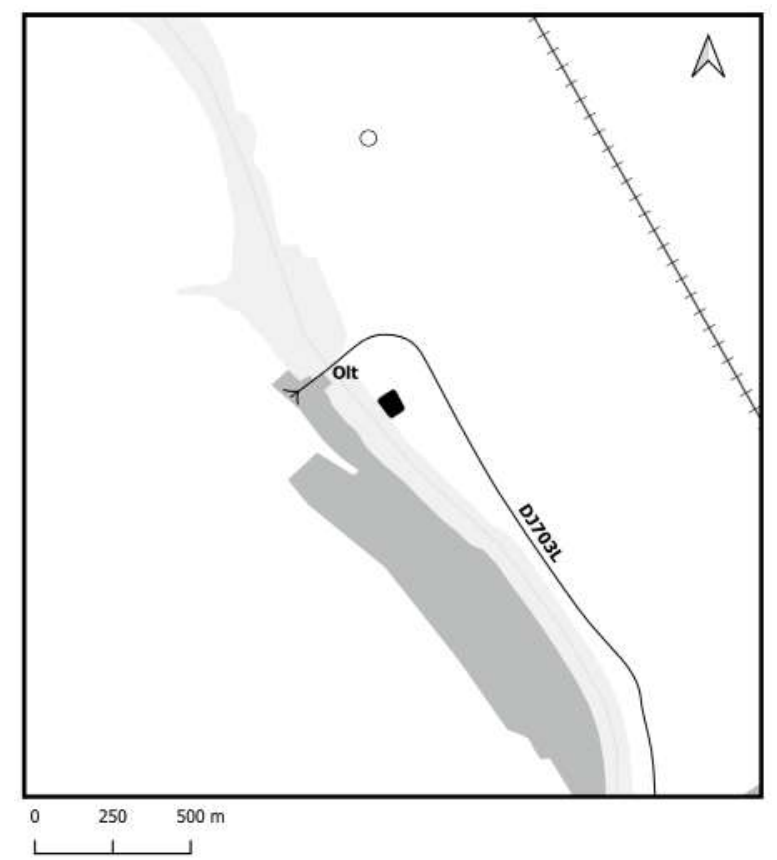

14.1. Călimănești (Arutela), localizarea sitului și a turnului de pe piscul lui Teofil. mutării la o cotă superioară pentru a face loc amenajării barajului Turnu. (Poenaru-Bordea, Gh. și Vlădescu, C. M. 1979, 235).

Castrul de piatră avea colțurile rotunjite și dimensiunile de $60,80 \times 60,80$ metri (?), porta praetoria pe latura estică (fig. 14.7 fig. 14.8); zid cu o grosime de 1,60 m lucrat în tehnica opus incertum; turnuri de colț de formă trapezoidală, uşor ieșite în exterior. Portae principales nu au fost prevăzute cu turnuri; în interior au fost identificate principalele drumuri; principia sunt parțial distruse; în praetentura dextra a fost identificat un horreum, și o altă construcție dreptunghiulară, $20 \times 9 \mathrm{~m}$, a cărei funcționalitate nu a putut fi stabilită;

Două inscripții de construcție din anul 138 p. Chr. atestă Suri sagittarii (CIL III $13793=$ IDR II 575; CIL III 13794 = IDR II 576). Pe un mic fragment de bronz a fost atestat un librarius cohortis I Hispanorum (CIL III 12602 = IDR II 582). De asemenea, a fost atestată o ștampilă a legiunii V Macedonica (IDR II 579).

Fortificația este restaurată, iar parte din clădirile păstrate pot fi vizitate. Porta praetoria este reconstituită pe baza unor presupuneri ipotetice avansate de colectivul de cercetare din deceniul opt al secolului trecut, fiind prima tentativă de acest fel din România.

Rambleul căii ferate de la sfârșitul sec. XIX (se poate observa în vederile din această perioadă) trecea printre „Masa lui Traian" la Vest (azi inundată) și Piscul Turnului/Vârful lui Teofil la Est. Această porțiune fusese inundată în momentul în care barajul Turnu a fost dat în folosință (1982). Noua cale ferată a fost mutată pe o terasă superioară, în funcțiune și astăzi (fig. 14.9 și fig. 14.10).

Pe linia stâncii numită „Masa lui Traian” (care altădată făcea corp comun cu masivul muntos, rămasă izolată prin spargerea rocii pentru montarea căii ferate), pe prima creastă mai înaltă, de la vest spre est către vârful muntelui Cozia, se află piscul lui Teofil, pe platoul căruia a funcționat un turn de observație roman (Vlădescu 1986, 60). Drumul roman se vedea tăiat mai mult în stâncă (fig. 14.4a/14.4b) la intrarea în defileu, trecând pe lângă „Masa lui Traian" (Tocilescu 1896, 105). O construcție importantă o reprezintă băile. Cea mai bună descriere a localizării băilor romane i se datorează lui Dumitru Tudor. Băile romane erau situate tot pe malul stâng al Oltului (între Cozia şi Piscul Turnului), la o mică depărtare de Masa lui Traian şi alături de drumul roman (Tudor 1942, 145).

După o altă vagă indicație a lui Gr. Tocilescu termele ar fi fost chiar în castru, dar cel mai probabil a fost surprinsă una din camerele clădirii comandamentului (principia) sau din casa comandantului (praetorium), prevăzută cu instalație de hypocaust. Pe un plan al lui P. Polonic, care corespunde planului băilor lui Tocilescu, topograful notase „Clădirea din mijlocul Cet. rom. de la Bivolari (Mân. Cozia)”. Informația a fost preluată în Marele Dicționar 
Geografic al României, şi explicată de D. Tudor în prima ediție a cărţii Oltenia romană (Tudor 1942, 145, nota 2). În mai multe publicații mai recente se perpetuează informații confuze privind amplasarea acestui edificiu. Observațiile privitoare la terme au fost publicate integral și adnotate.

Bibliografie: Tocilescu, G. 1891. Neue Inschriften aus der Dobrudscha, Archäologisch-Epigraphische Mittheilungen aus Österreich-Ungarn 14: 13-14, nr. VI; Tocilescu, Gr. 1896. Raport asupra lucrărilor de exploatare întreprinse pe limes Alutanus, Analele Academiei Române, Desbaterile 18: 103-105; Tocilescu 1900, 135; Christescu 1937, 199; TIR L 35, 27; Tudor, D. 1942. Castra Daciae Inferioris IV: Castrul și băile romane de la Bivolari pe Olt. Buletinul Comisiunii Monumentelor Istorice 35 fasc. 113/114: 143-149; Tudor 1968, 371; Tudor, D. 1969. Le camp romain d'Arutela, în: J. Bibauw (éd.), Hommages à Marcel Renard. II. Histoire, histoire des religions, épigraphie. Latomus 102, Bruxelles: 579-585; Poenaru-Bordea, Gh., Vlădescu, C. M. 1969, Date noi în legătură cu castrul Arutela, Studii și Cercetări de Istorie Veche 20, 1: 101-111; Tudor, D., Poenaru-Bordea, Gh. și Vlădescu, C.M. 1969. Rezultatele primelor două campanii de săpături arheologice (1967 - 1968) în castrul roman din Poiana Bivolari, oraşul Călimăneşti, Arutela, I, II. Studii şi materiale de muzeografie şi istorie militară 2-3: 8-45; Poenaru-Bordea, Gh., Vlădescu, C.M. 1972: Primele săpături arheo-logice în fortificaţia romană de la Rădăcineşti. SCIV 23, 447-86; Tudor, D., Vlădescu, C. M. și Poenaru Bordea, Gh. 1973. Arutela III-IV. Observații asupra campanii arheologice din 1969-1970, Studii şi materiale de muzeografie şi istorie militară 6, 19-26; Vlădescu, C.M., PoenaruBordea, Gh. 1972, 3: 27-32; Vlădescu, C.M., Poenaru-Bordea, Gh. 1974, 47-59; Tudor 1978, 259-265, nr. 3, 313-315; Poenaru Bordea, Gh., Vlădescu, C. M și Stoica, O. 1979. Arutela V. Campania de săpături de salvare din 1978, Studii şi materiale de muzeografie şi istorie militară 12: 124-125; Poenaru-Bordea, Gh., Vlădescu, C. M. 1979, Săpăturile de salvare de la castrul Arutela din 1978, Materiale și Cercetări Arheologice 13: 235-236; Bogdan-Cătăniciu, I. 1981: 27-28; Vlădescu, C.M. 1982. 55-65; Vlădescu 1983, 92-101, nr. 14; Vlădescu, C.M. 1985, 33-41;Vlădescu 1986, 46-60; Gudea 1997, 91, nr. 78; Marcu 2009, 181-187, nr. 39.

Turnul de pe Piscul lui Teofil (pl. II) Este localizat la aproximativ 900-1000 m nord față de actualul castru Arutela, în dreptul stâncii numită „Masa lui Traian” (care altădată făcea corp comun cu masivul muntos, dar a rămas izolată prin spargerea rocii pentru montarea căii ferate), pe prima creastă mai înaltă, de la vest spre est către vârful muntelui Cozia. Pe „Piscul lui Teofil” a fost realizat un mic platou pe care s-au descoperit fundațiile unui turn confirmat prin săpături arheologice. Forma este ussor atipică, reprezentând o treime a unui arc de cerc, cu partea dreaptă către Est (Vlădescu 1986, 61 fig. 52-53). În interior a fost identificată o substrucție din mortar, conținând fragmente de cărămizi. Fiind la o înălțime considerabilă, turnul putea asigura o vizibilitate deosebită, atât pe cursul defileului către Rădăcinești, anume cu Văratica (fig. 13.1) sau către alte turnuri de semnalizare din aval.

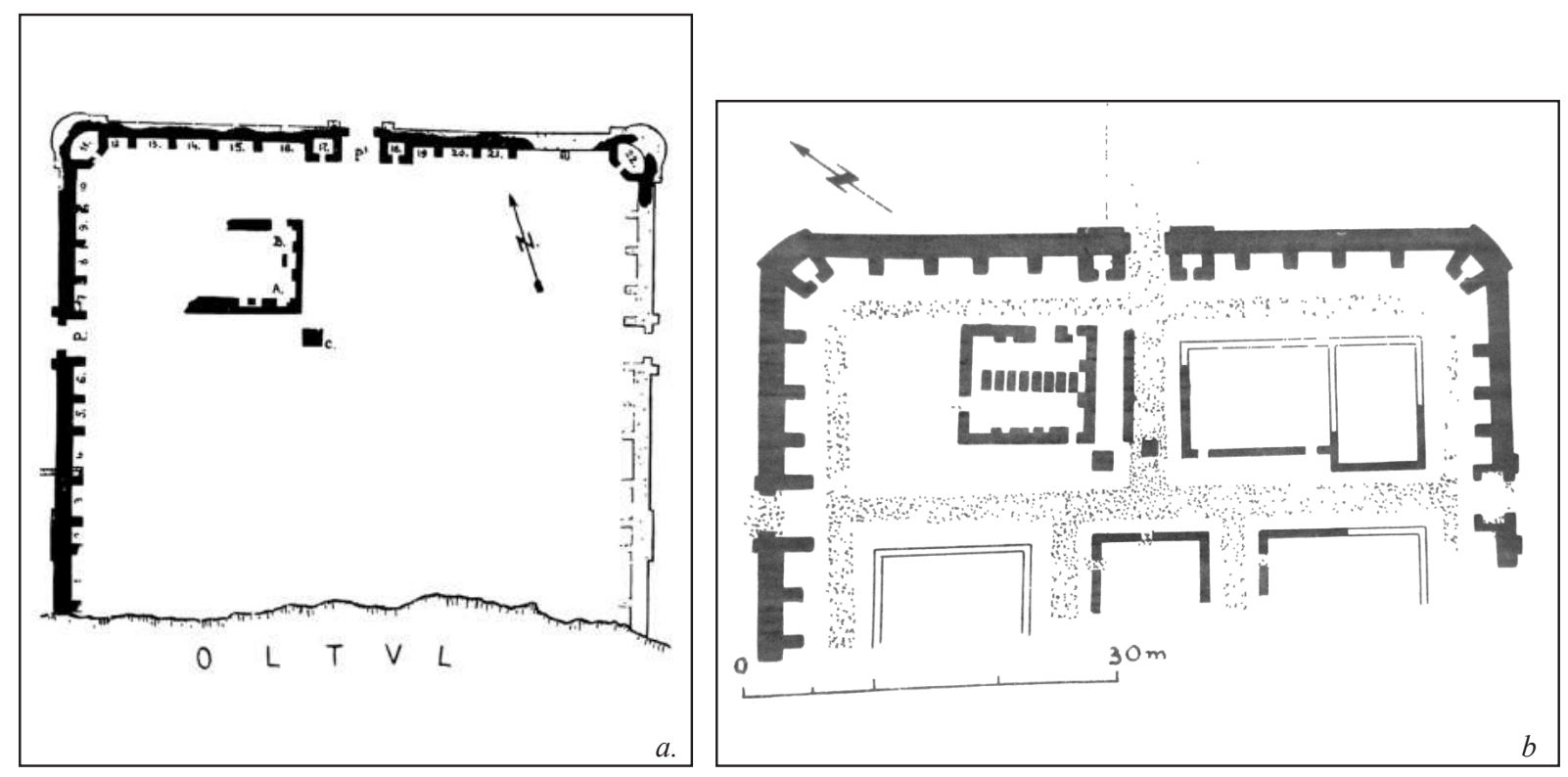

14.2. Călimănești (Arutela), planul castrului: a. Gr. Tocilescu (Tudor 1942, 144, fig. 1); b. (Poenaru-Bordea și Vlădescu 1974, 248, fig. 2). 
Bibliografie: Tudor, D., Vlădescu, C. M. și Poenaru Bordea, Gh. 1973. Arutela III-IV. Observații asupra campanii arheologice din 1969-1970, Studii şi materiale de muzeografie şi istorie militară 6: 19-26 (16); Tudor 1978, 264; Vlădescu 1986, 60.

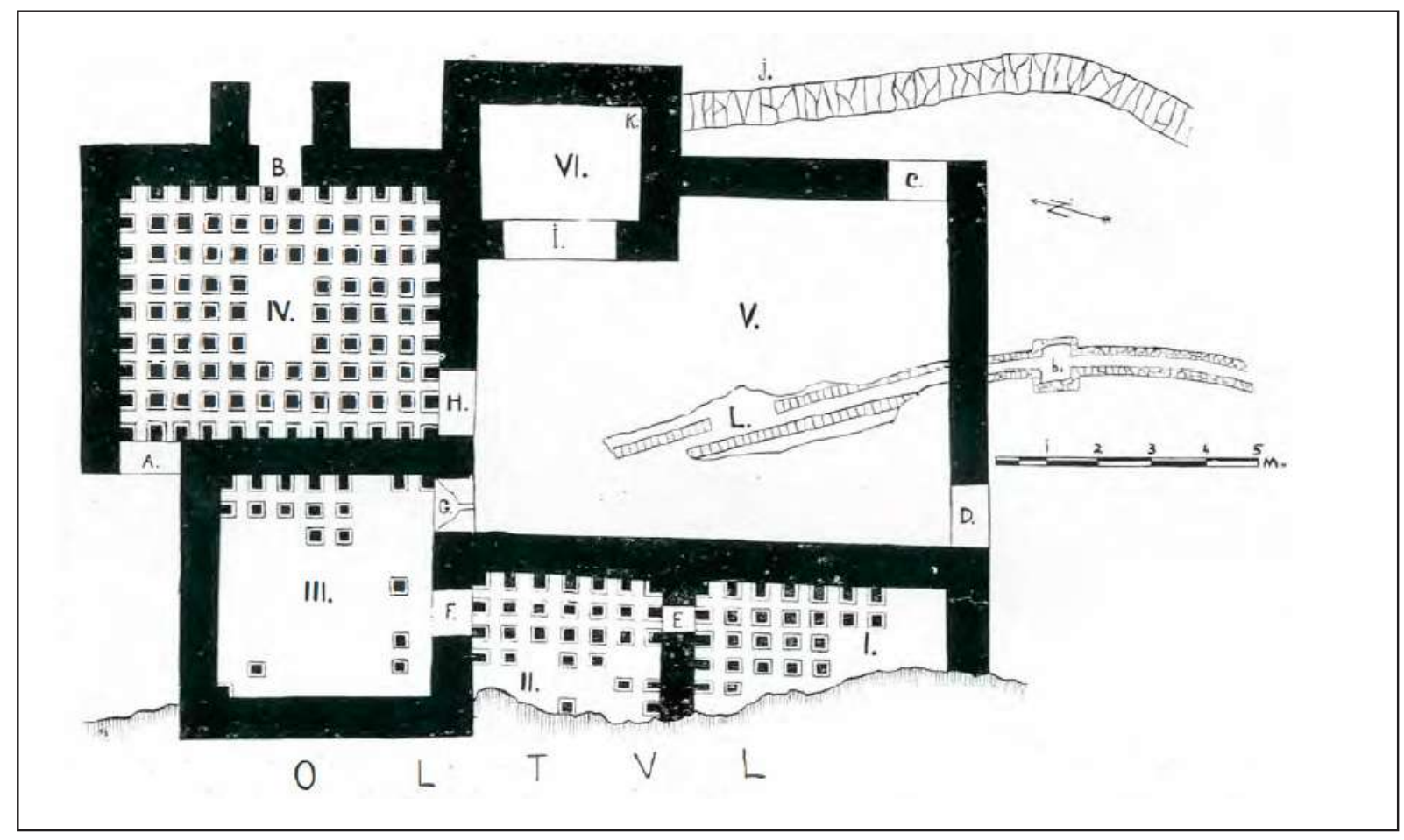

14.3. Călimănești (Arutela), planul băilor de la Arutela realizat de Gr. Tocilescu (Tudor 1942, 146, fig. 3).

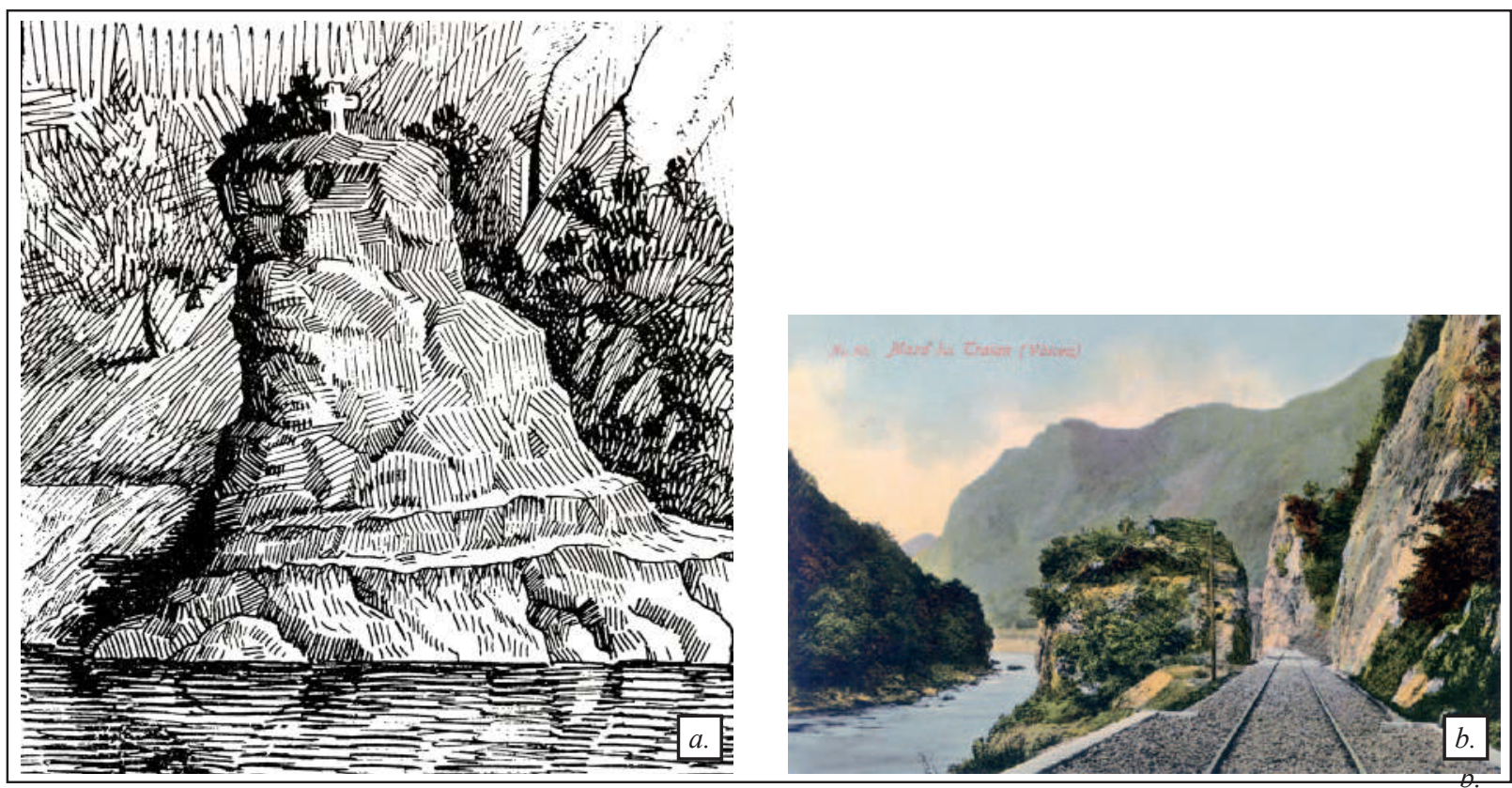

14.4. Călimănești (Arutela): a. "Masa lui Traian" (Tudor 1978, 51, fig. 3);

b. vedere spre "Masa lui Traian" și vechea cale ferată. Perspectivă dinspre Sud-Est

(ilustrată, 1909 - ipostază similară https://www.europeana.eu/en/item/2058616/omeka_items_show_1738). 

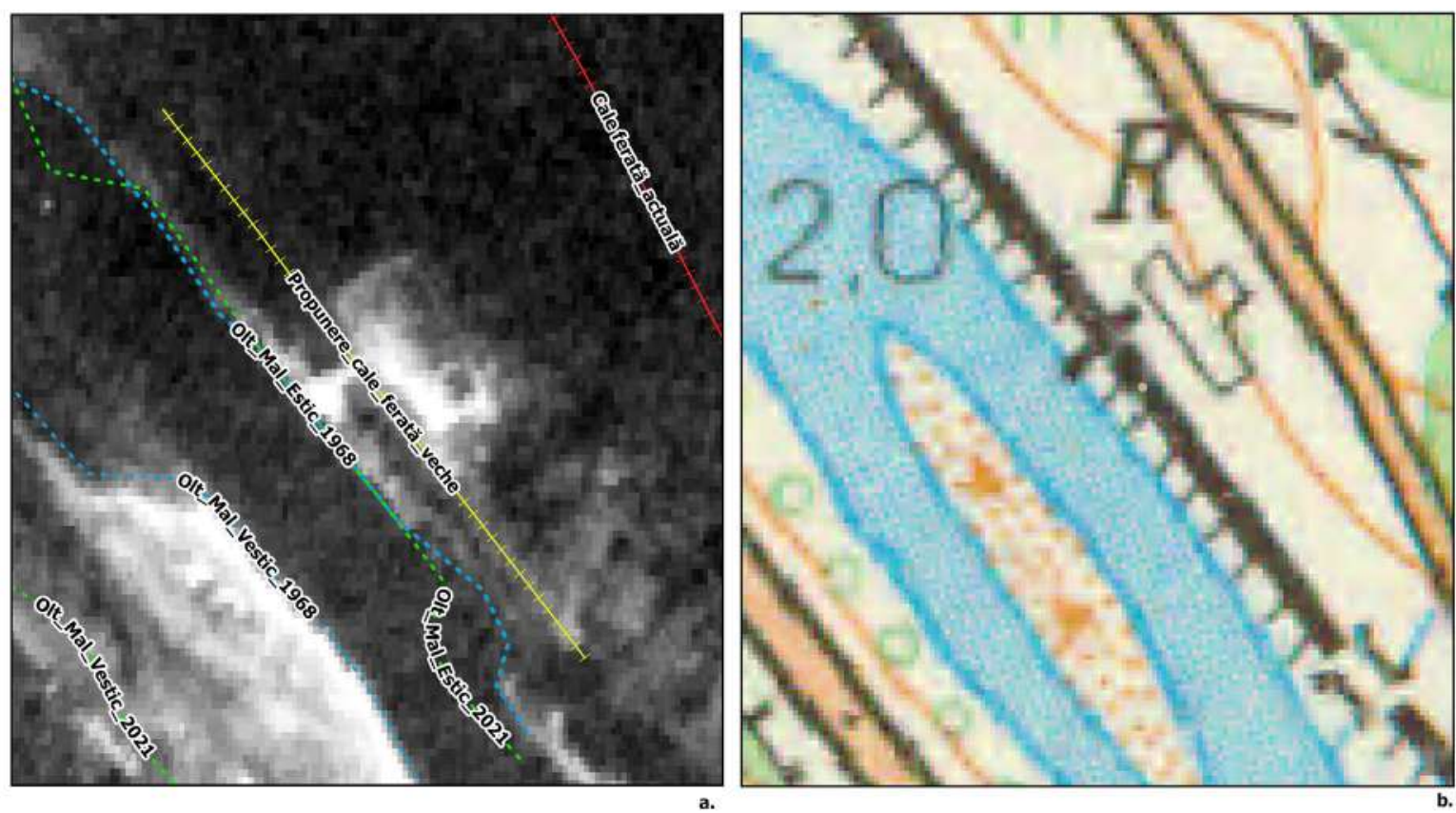

$0 \quad 25 \quad 50 \mathrm{~m}$
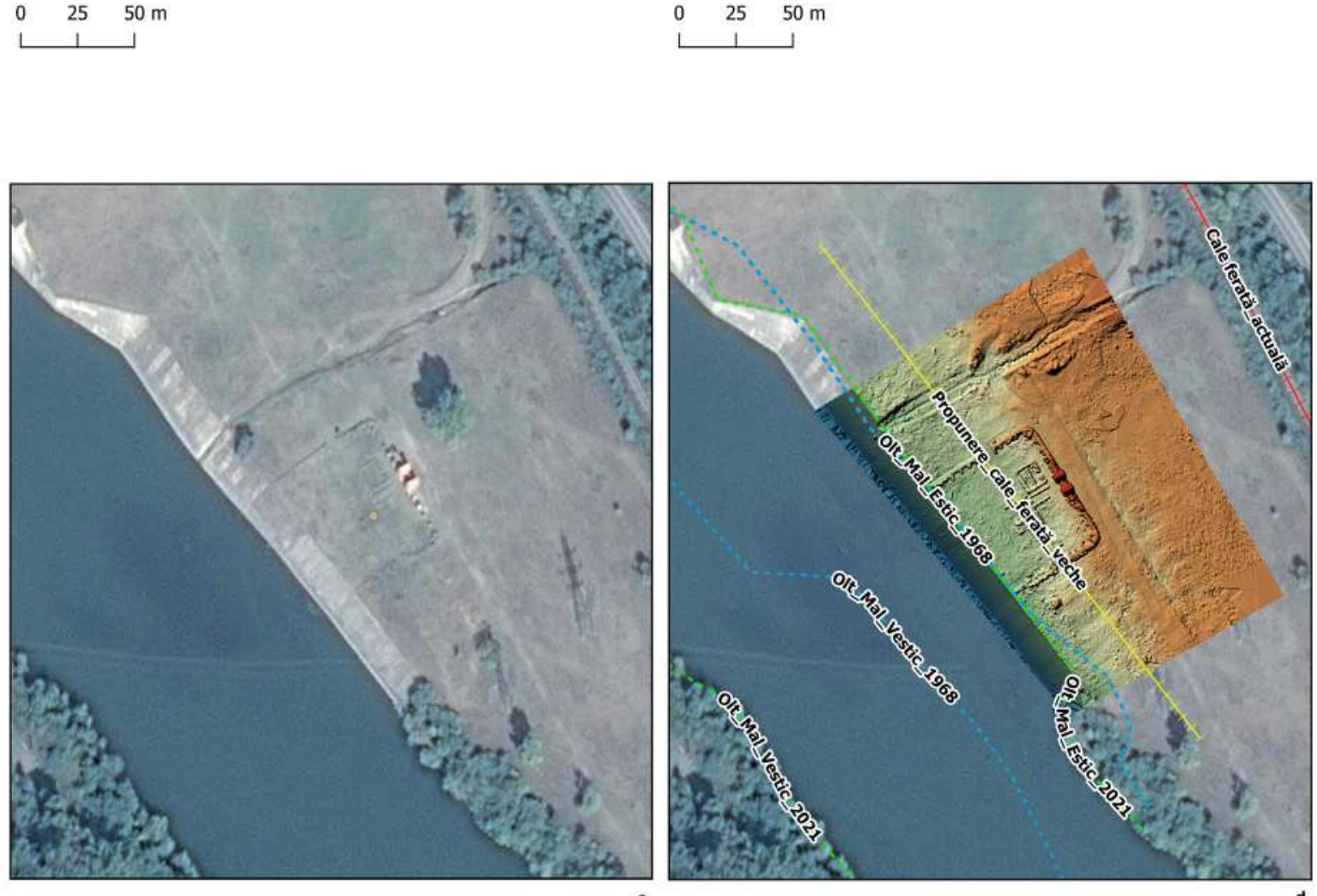

$0 \quad 25 \quad 50 \mathrm{~m}$

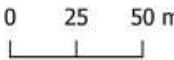

d.

14.5. Călimănesti (Arutela), localizarea castrului:

a.fotografie declasificată satelit Corona 1968 (1104-2155Aft; Aug 17 1968_Center for Advanced Spatial Technologies,

University of Arkansas/U.S. Geological Survey;

b. localizarea castrului pe harta topografică militară 1970-1980,

c. localizarea castrului Imagine satelitară Google Earth 2021;

d. suprapunerea modelului digital al terenului pe Imagine satelitară Google Earth 2021. 


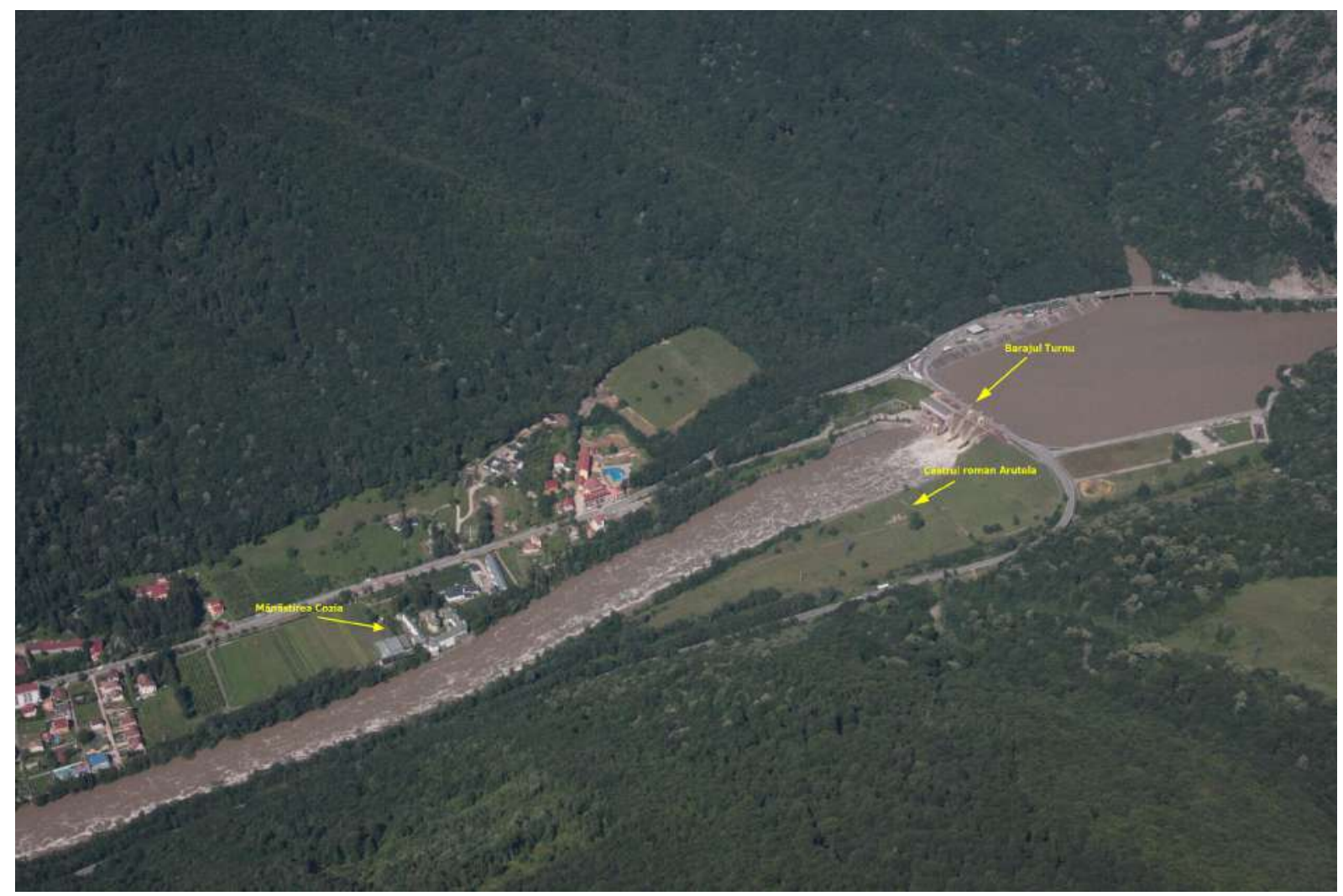

14.6. Călimănești (Arutela), fotografie oblică aeriană, vedere dinspre Sud-Est (5 iulie 2010).

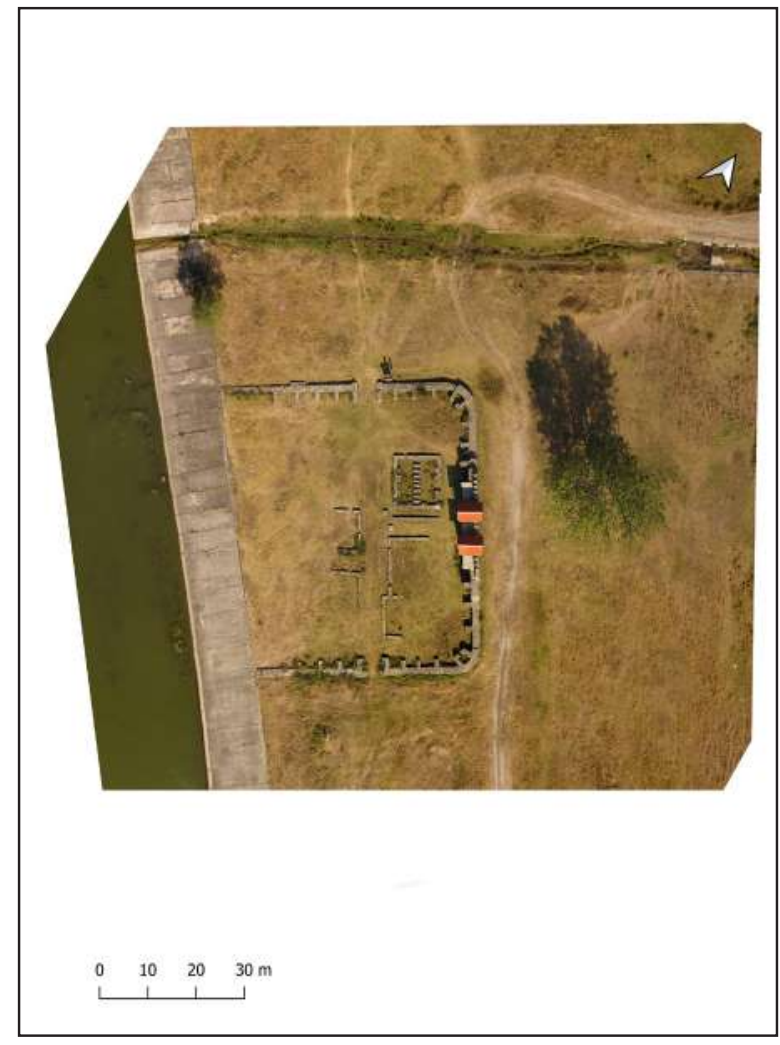

14.7. Călimănești (Arutela), ortofotoplan dronă.

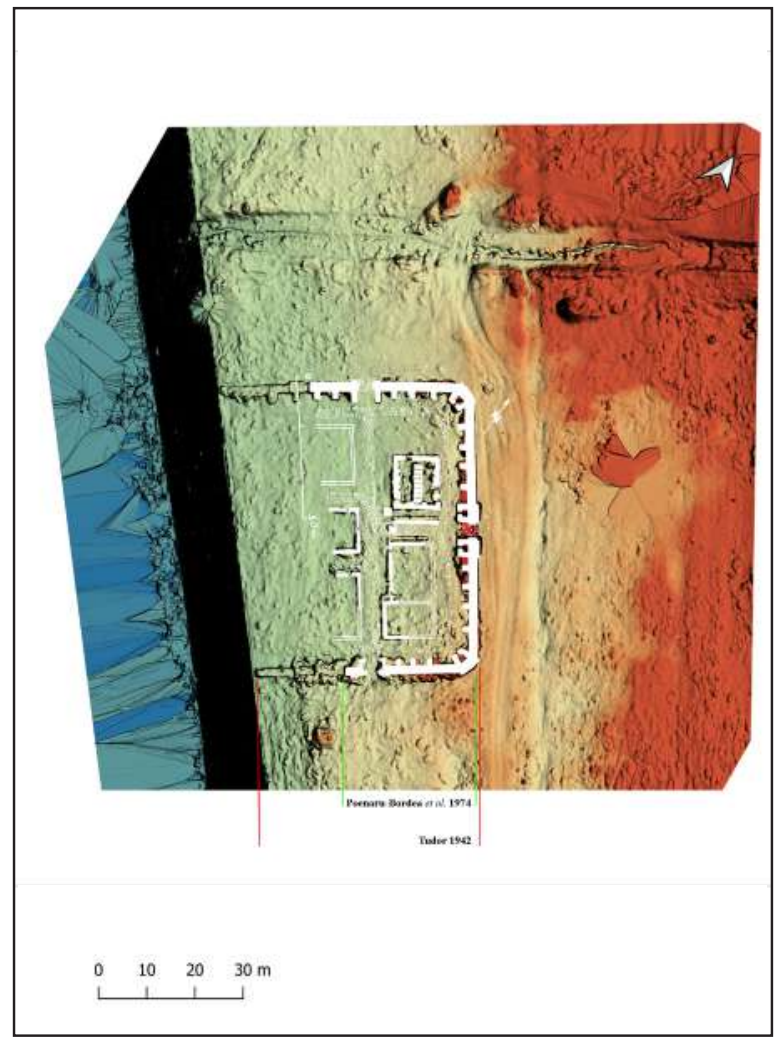

14.8. Călimănești (Arutela), suprapunerea planurilor castrului (Poenaru-Bordea și Vlădescu 1974, 248, fig. 2) pe modelul digital al terenului. 

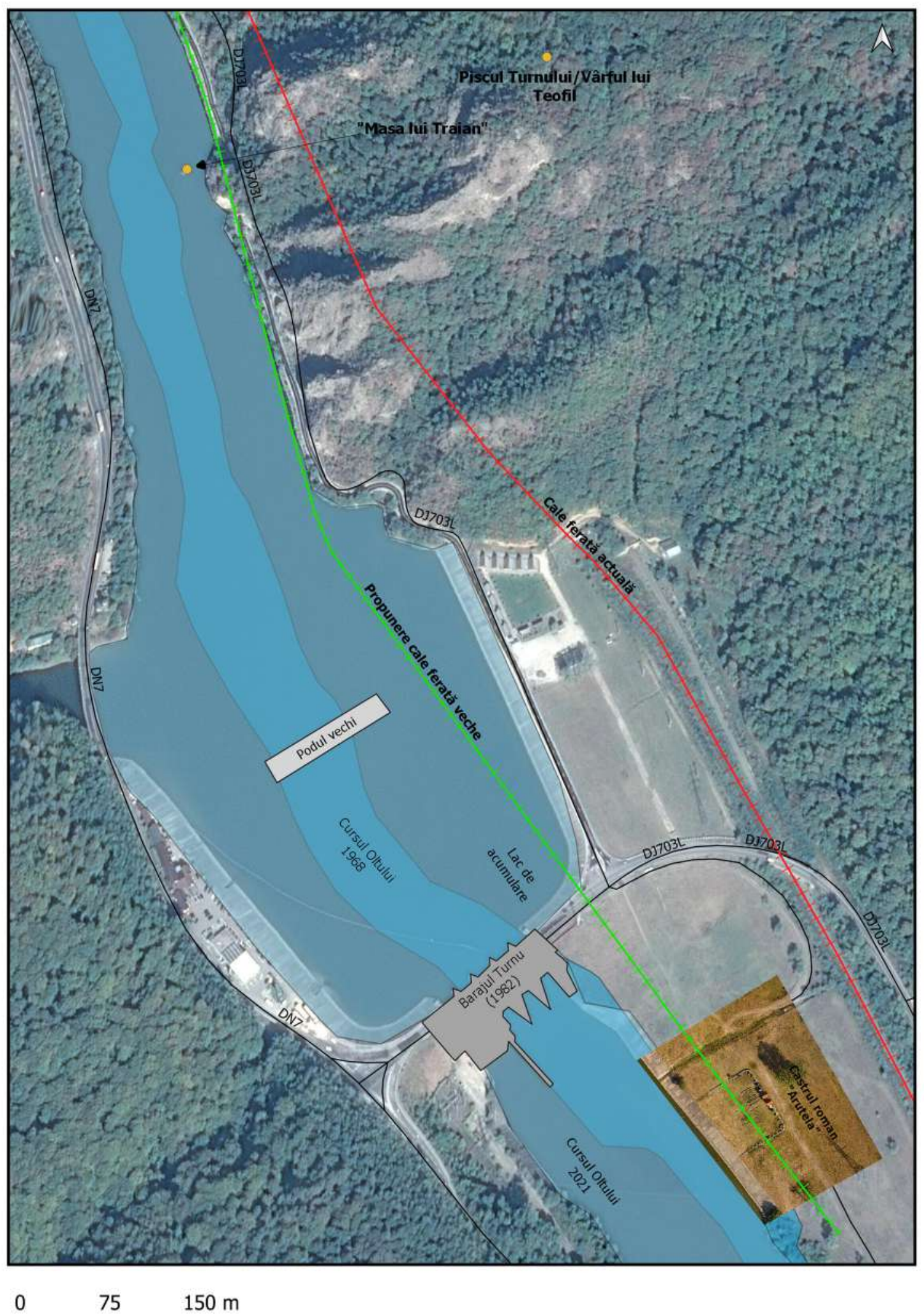

14.9. Călimănești (Arutela), cursul Oltului în anii 1968 și 2021, în zona actualului baraj Turnu, suprapunere pe Imagine satelitară Google Earth 2021. 


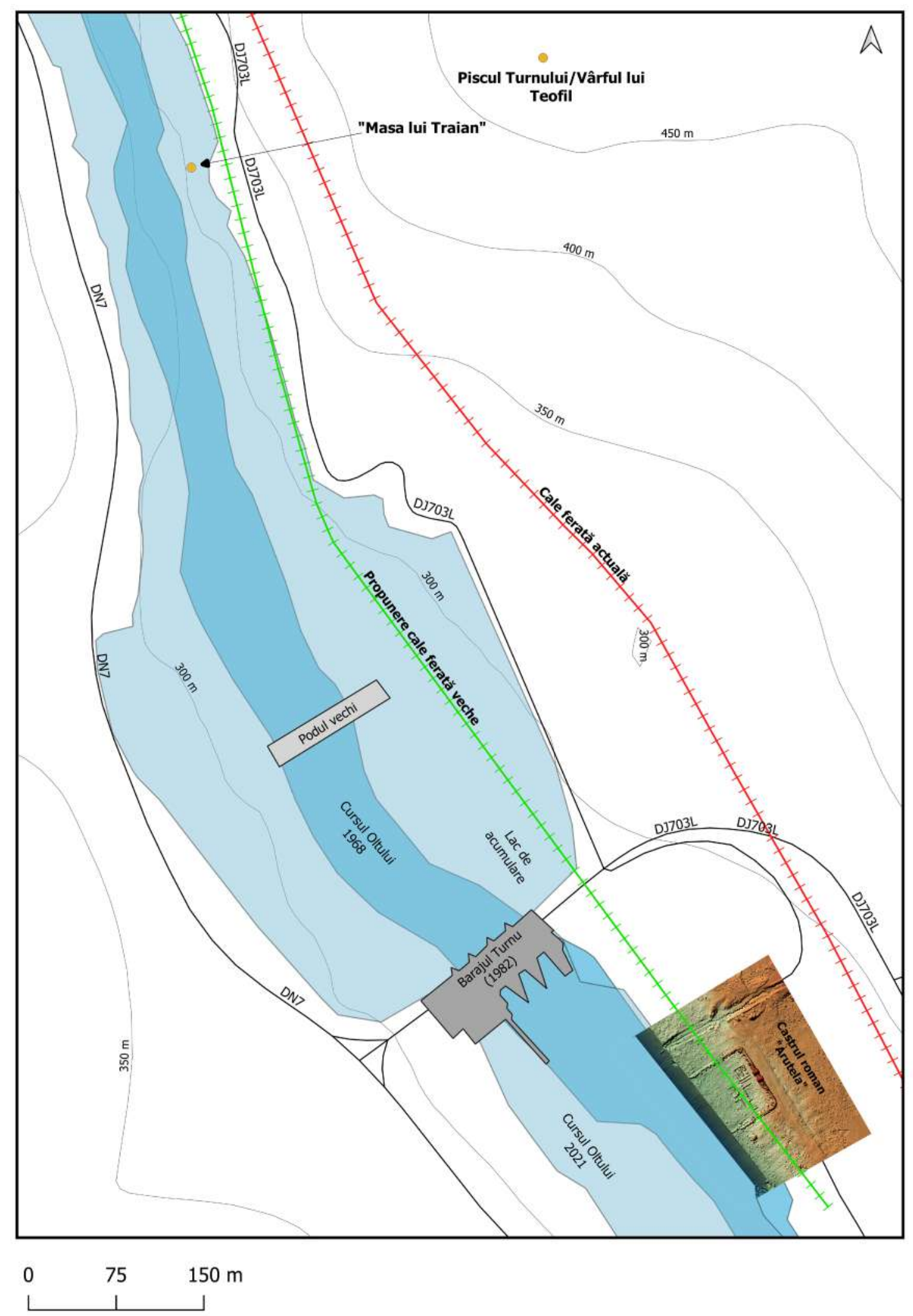

14.10. Călimănești (Arutela), cursul Oltului în anii 1968 și 2021 în zona actualului baraj Turnu, suport QGIS. 


\section{Jiblea}

Călimănești, jud. Vâlcea (RAN: 167945.03)

La Jiblea (fig. 15.1 - 15.4) a fost presupusă existența unei fortificații romane, însă ipoteza nu a putut fi validată în lipsa unor cercetări extinse. Arealul este situat la Sud de Jiblea Veche şi la Est de Jiblea Nouă, astăzi componente ale orașului Călimănești, în vecinătatea confluenței cu pârâul Seaca.

În acest areal se bifurcă drumul care intra spre Nord în primul defileu al Oltului cu cel care ocolea spre Est masivul Cozia, de-a lungul căruia au fost amplasate castrele de la Rădăcinești, Pripoare (?) și Titești.

D. Tudor presupunea existența unei fortificații în punctul Gaitini, un dreptunghi de $60 \times 100$ pași, cu val și șanț, văzut cu claritate la $100 \mathrm{~m}$ Vest de traseul drumului roman (Tudor 1968, 293, fig. 73/2). Același autor susținea un deceniu mai târziu (Tudor 1978, 281) că presupusul castru roman este în realitate o fortificație de pământ (medievală?).

Pe baza reperelor prezentate, am realizat recunoașteri la fața locului, care nu au dus la rezultate concludente. Putem presupune localizarea fortificaţiei la care făcea referire D. Tudor (fig. 15.2-15.4). Este necesară colectarea unor informații suplimentare pentru a definitiva localizarea.

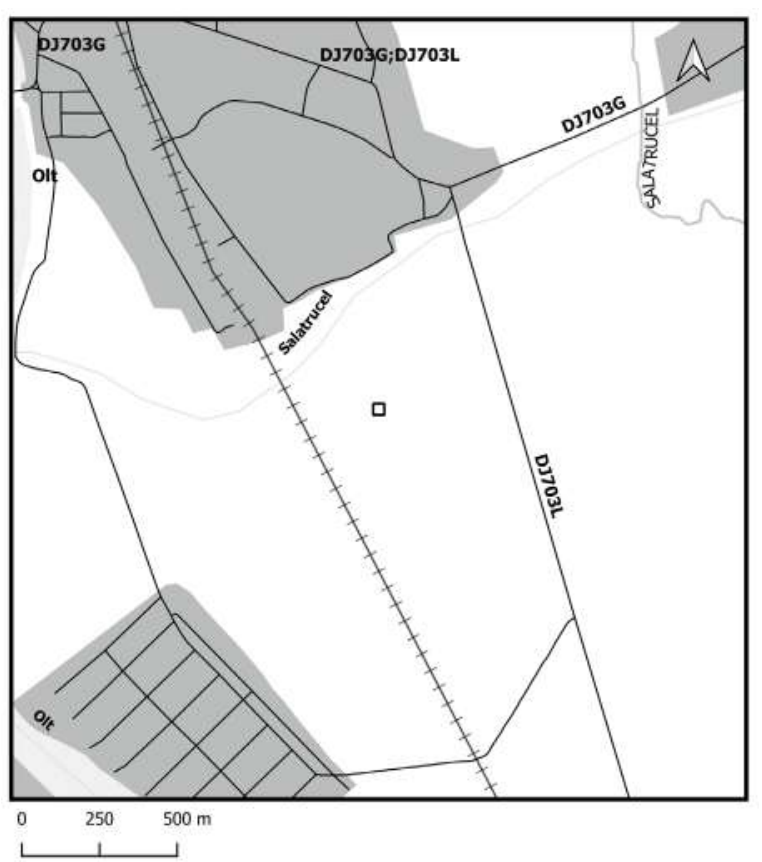

15.1. Jiblea, localizarea presupusă a fortificației.

Bibliografie: Tudor 1968, 293, fig. 73/2; Tudor

1978, 281; Bogdan-Cătăniciu 1981, 27, 82 nota 246; Gudea 1997, 90, fig. 76 - 14.1.

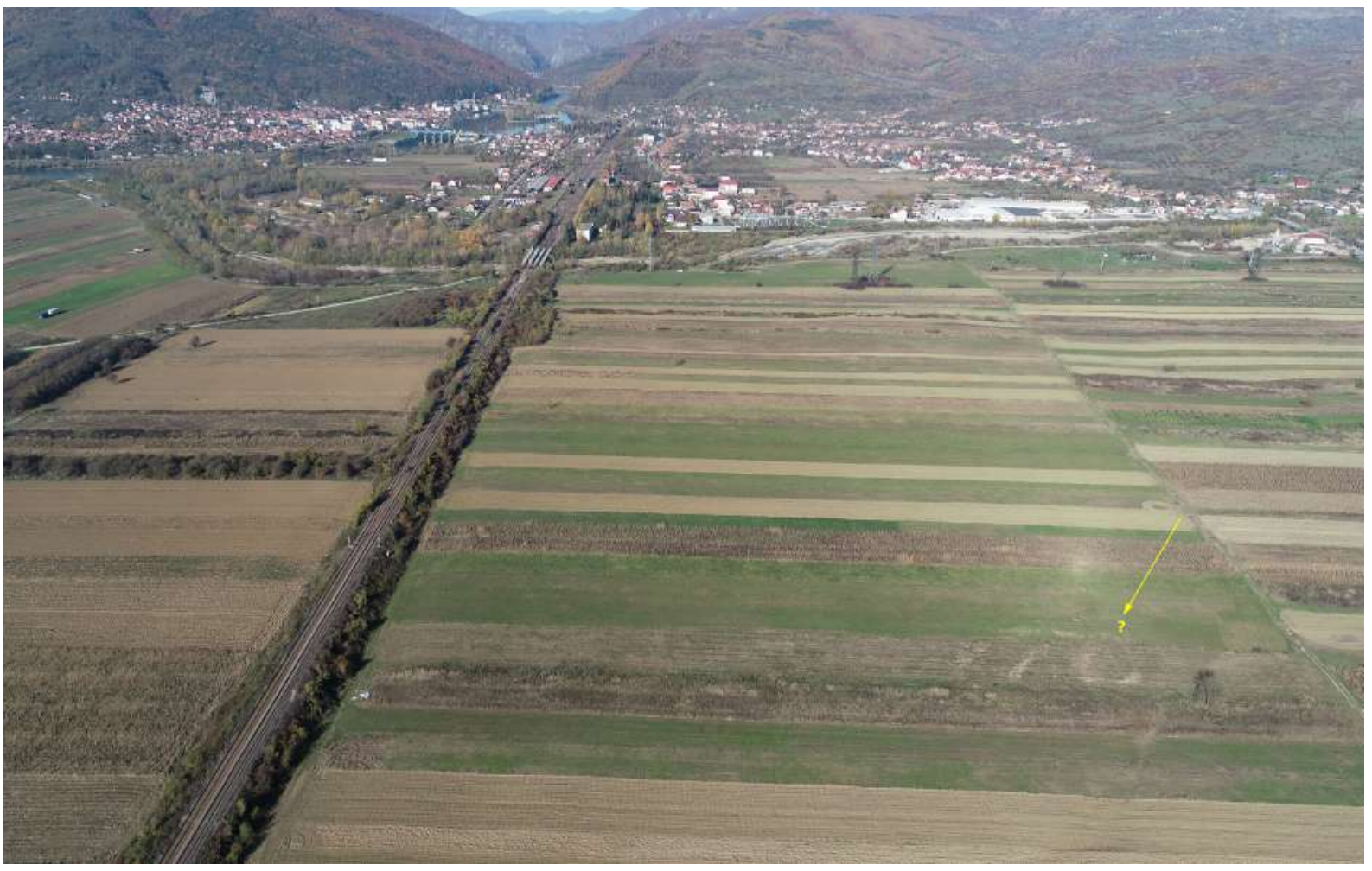

15.2. Jiblea, fotografie oblică din dronă, vedere dinspre Sud-Est (noiembrie 2020). 


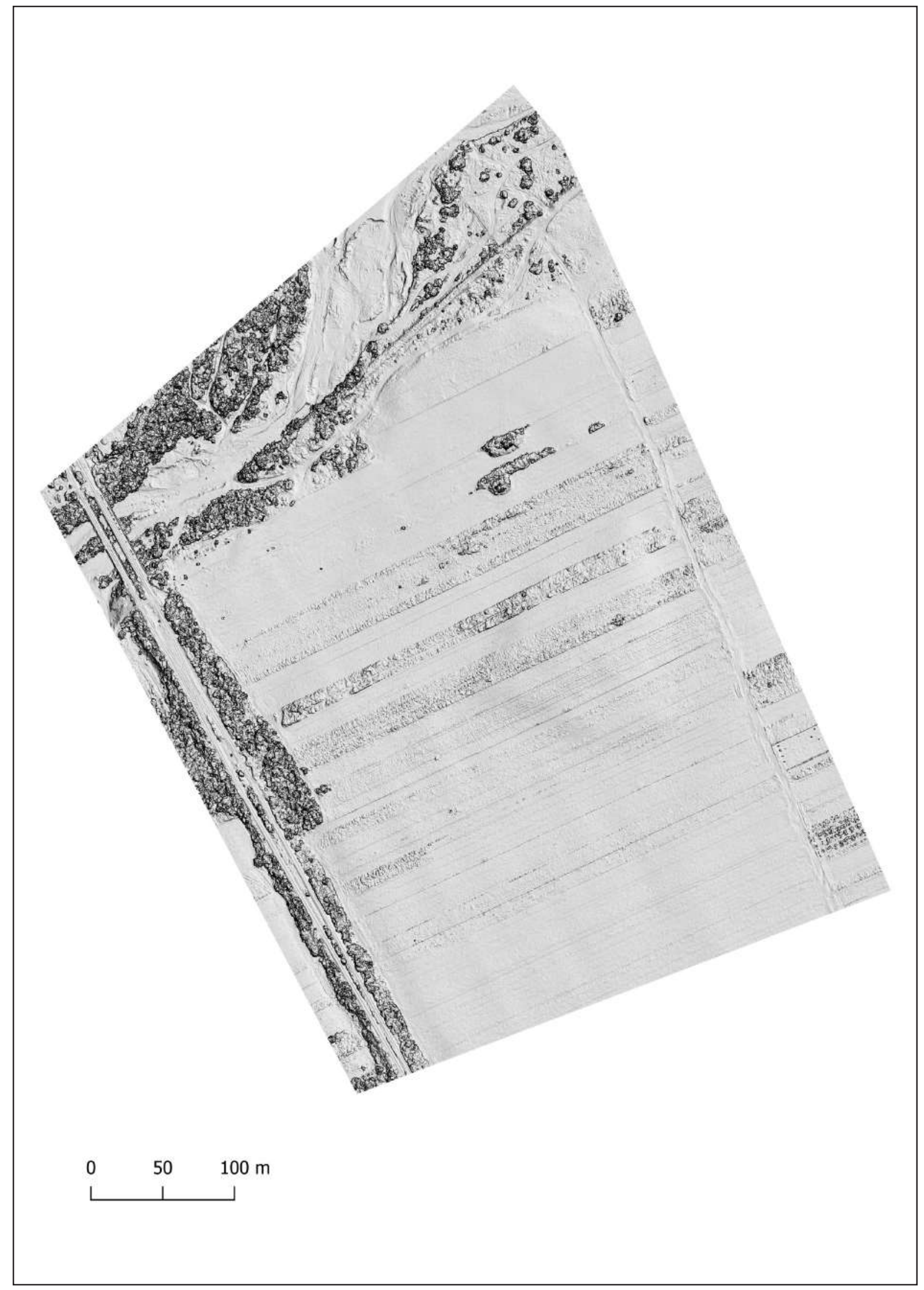

15.3. Jiblea, model digital umbrit (hillshade). 


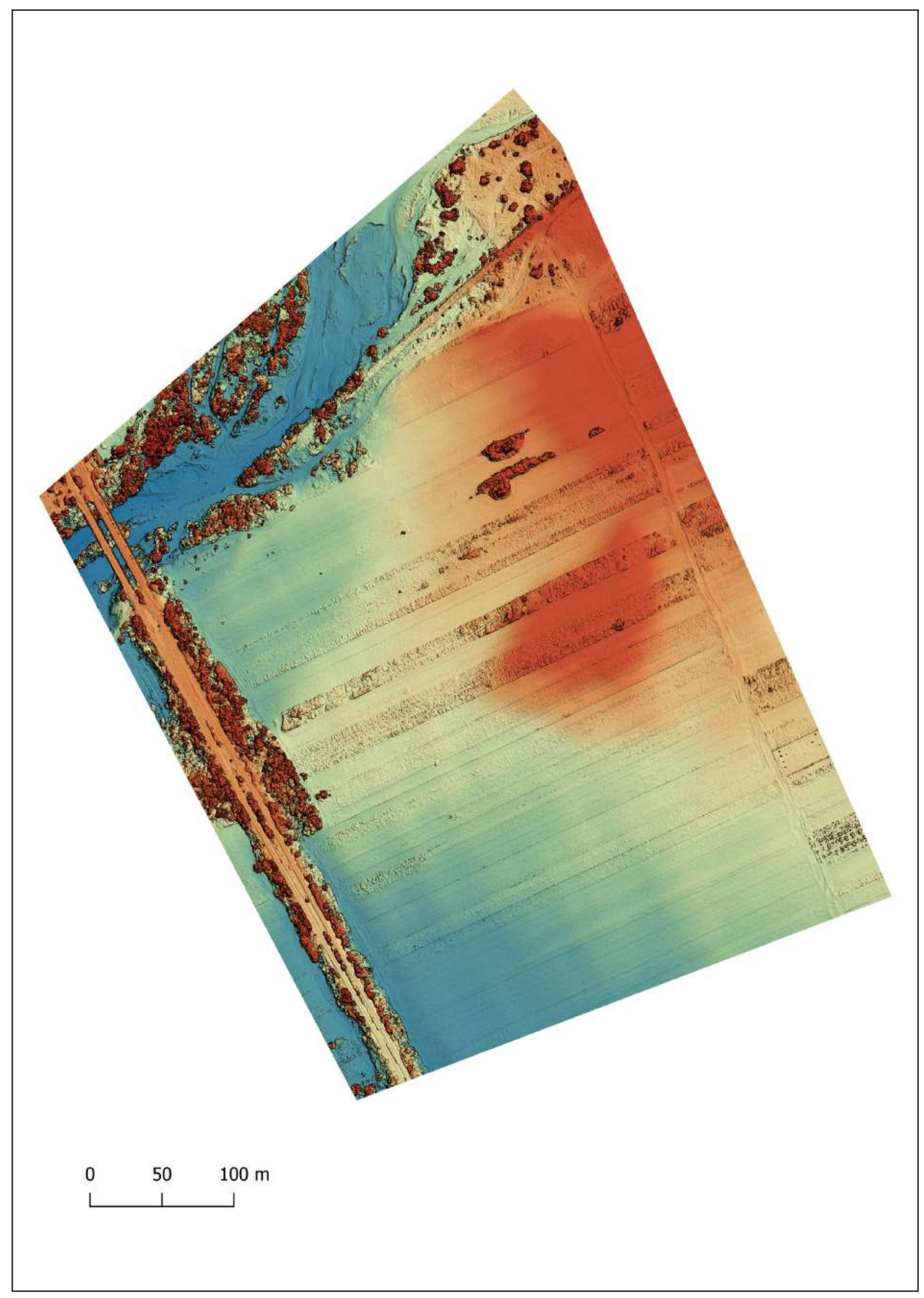

15.4. Jiblea, modelul digital al terenului. 


\section{Sânbotin (Castra Traiana?, Tabula Peutingeriana VIII, 1)}

Com. Dăeşti, jud. Vâlcea (RAN: 169397.01; VL-I-s-B-09574)

Fortificația (fig. 16.1 - 16.8) este situată la Sud de localitatea actuală, în punctul Cetate, pe o terasă înaltă, în apropiere de vărsarea pârâului Trant în Olt. Astăzi acoperit de construcții moderne, fiind vizibilă doar o parte din latura estică, zonă în care s-au făcut săpături de salvare (D. Tudor, H. Nubar, P. Purcărescu 1966; Cr. M. Vlădescu, Gh. Poenaru-Bordea 1983-1985). Săpăturile arheologice au evidențiat două faze: castrul de pământ, presupus de epoca traianică, respectiv castrul de piatră. Dimensiunile laturii de Est nu au putut fi precizate, păstrându-se pe o lungime de $69,60 \mathrm{~m}$. Zidul de piatră, realizat în tehnica opus incertum, avea o grosime de $1,50 \mathrm{~m}$. Pe această latură au fost semnalate două șanțuri de apărare, respectiv turnuri de curtină, de formă patrulateră, ieșite ușor în afară. În interior au fost descoperite urmele unor barăci de lemn. Pe baza observațiilor referitoare la arhitectura fortificației şi la artefactele descoperite s-a presupus construirea castrului de piatră în epoca lui Hadrianus. A fost descoperită o ştampilă a cohortei I Hispanorum (AE 1995, 1305), care ar putea data din epoca lui Traian sau Hadrianus.

Pe baza modelului digital al terenului (fig. 16.8), am încercat o reconstituire a formei și dimensiunilor fortificației, dar ipoteza noastră de lucru are un mare grad de probabilitate).

Bibliografie: Tudor, D., Nubar, H. și Purcărescu, P. 1970. Săpăturile arheologice de la Castra Traiana. Materiale și Cercetări Arheologice 9: 245-250; TIR L 35, 66; Tudor 1968, 272-273; Tudor 1978, 271, nr. 11; Vlădescu 1983, 91-92, nr. 13; Vlădescu 1986, 43-46; Vlădescu, C. M. și Poenaru-Bordea, Gh. 1992. Castra Traiana, (Sâmbotin, jud. Vâlcea). Materiale şi Cercetări arheologice. A XVII-a Sesiune anuală de rapoarte. Ploieşti 1983. Bucureşti: Editura Academiei Române: 223-229; Avram, R., Avăsiloaiei, D. 1995. Garnizoana romană de la Castra Traiana. Studii și Cercetări de Istorie Veche și Arheologie 46: 193-195; Gudea 1997, 89-90, nr. 75; Petolescu 2002, 110; Gudea 2005, 496, nr. VII. B. 6; Marcu 2009, 230-231, nr. 69; Vlădescu, C.M., Poenaru-Bordea, Gh. 1992: Castra Traiana, (Sâmbotin, jud. Vâlcea). Materiale și cercetări arheologice. A XVII-a Sesiune anuală de rapoarte, Ploieşti 1983, Bucureşti: Editura Academiei Române: 223-230.

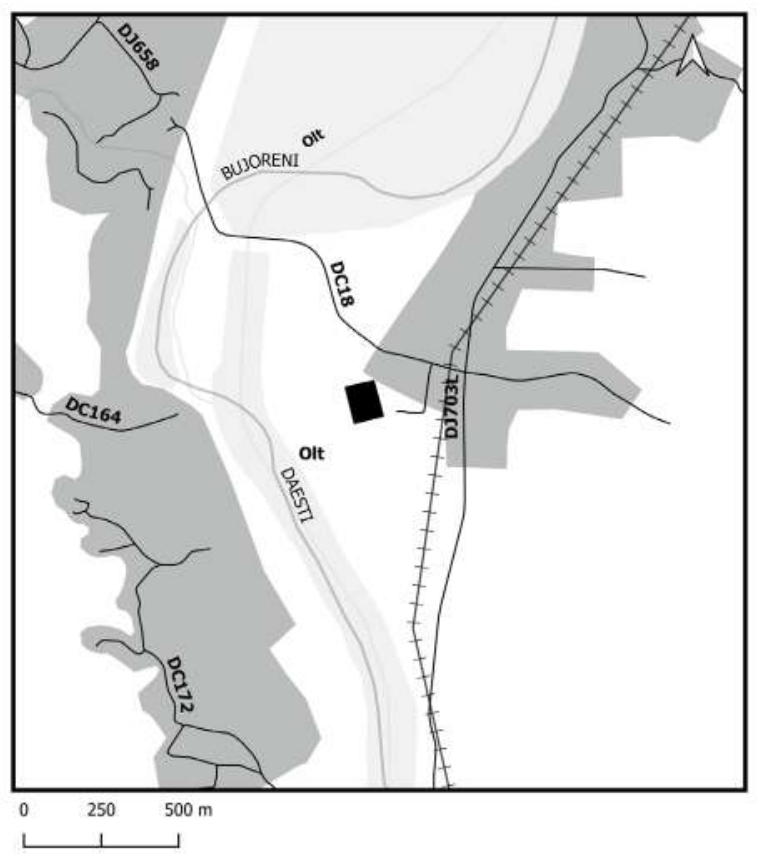

16.1. Sânbotin (Castra Traiana), localizarea sitului. 


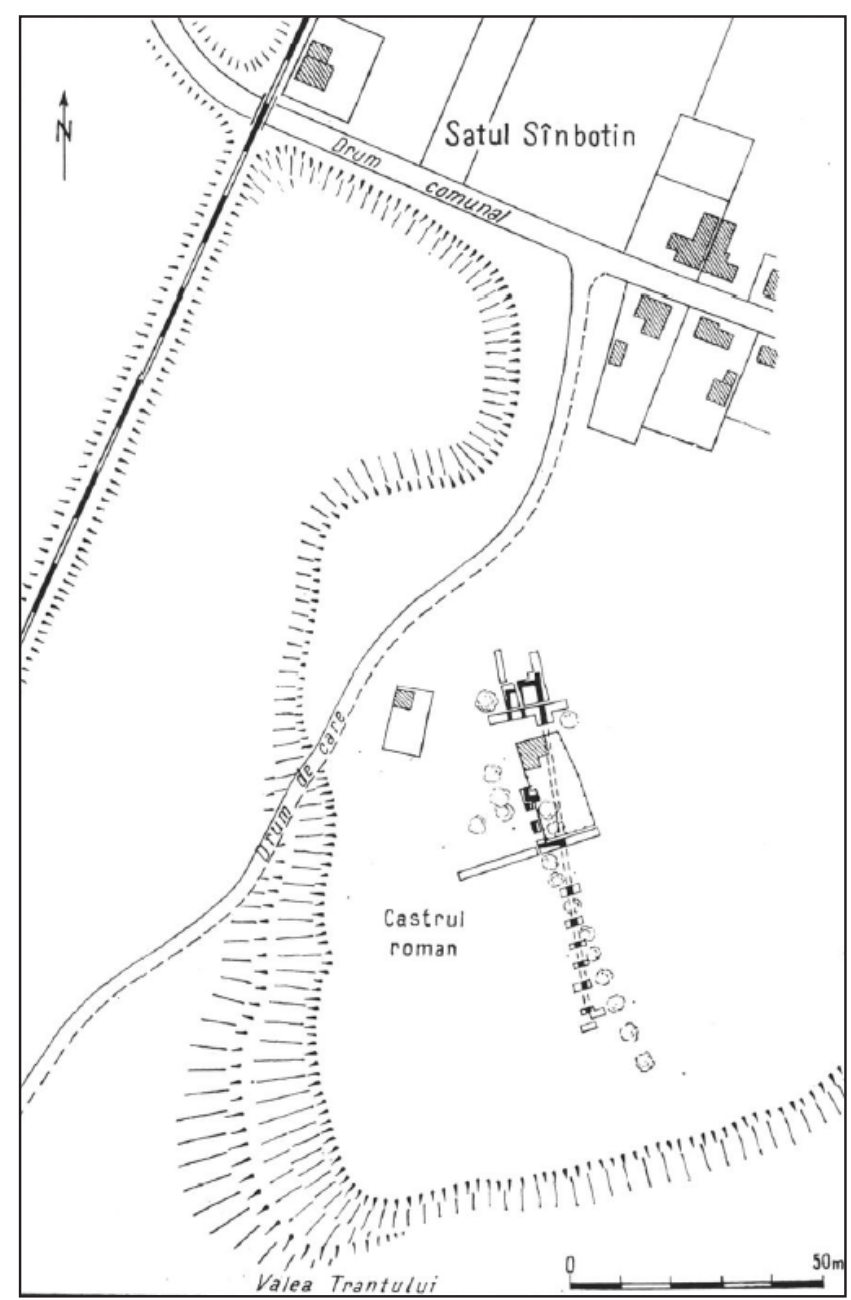

16.2. Sânbotin (Castra Traiana), planul săpăturilor arheologice (Tudor et al. 1970, 246, fig. 1).

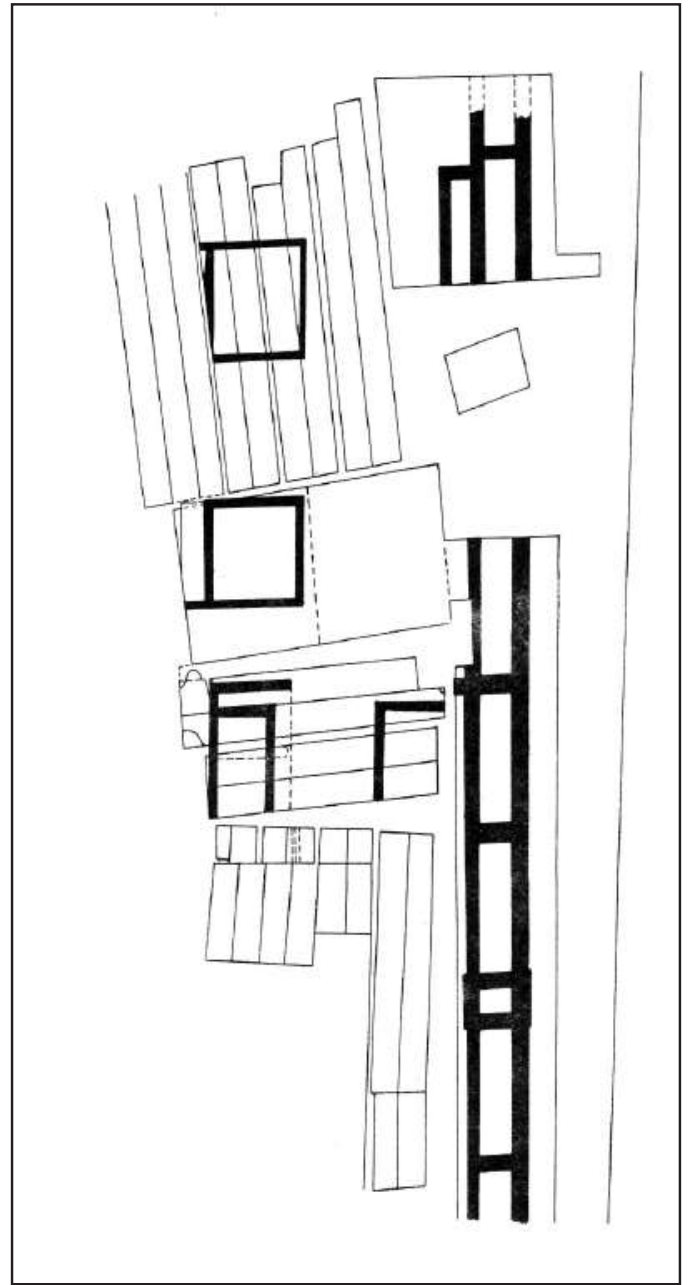

16.3. Sânbotin (Castra Traiana), planul incintei de est (Bogdan-Cătăniciu 1997, fig. 35).

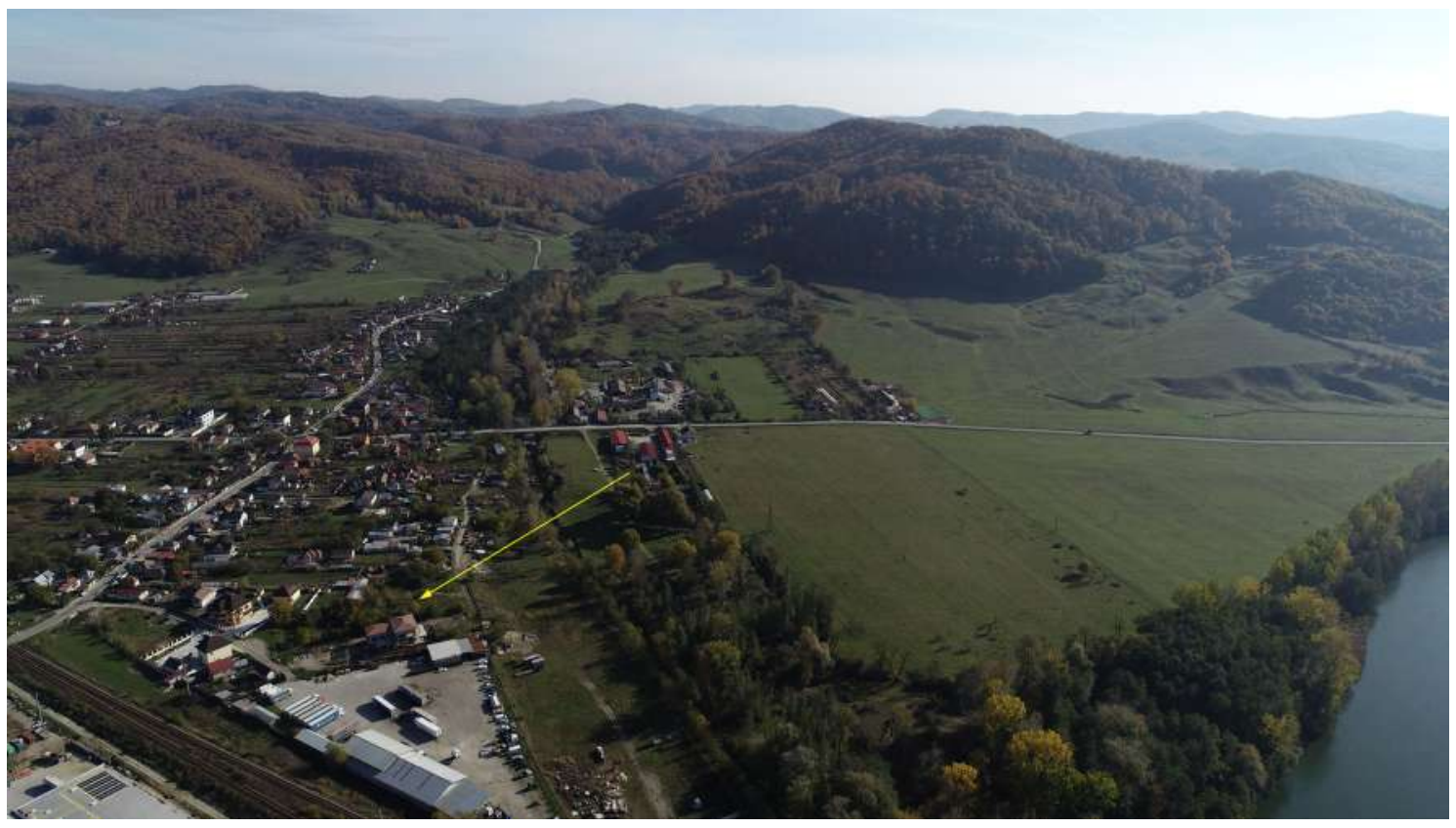

16.4. Sânbotin (Castra Traiana), fotografie oblică din dronă, vedere dinspre vest (noiembrie 2020). 


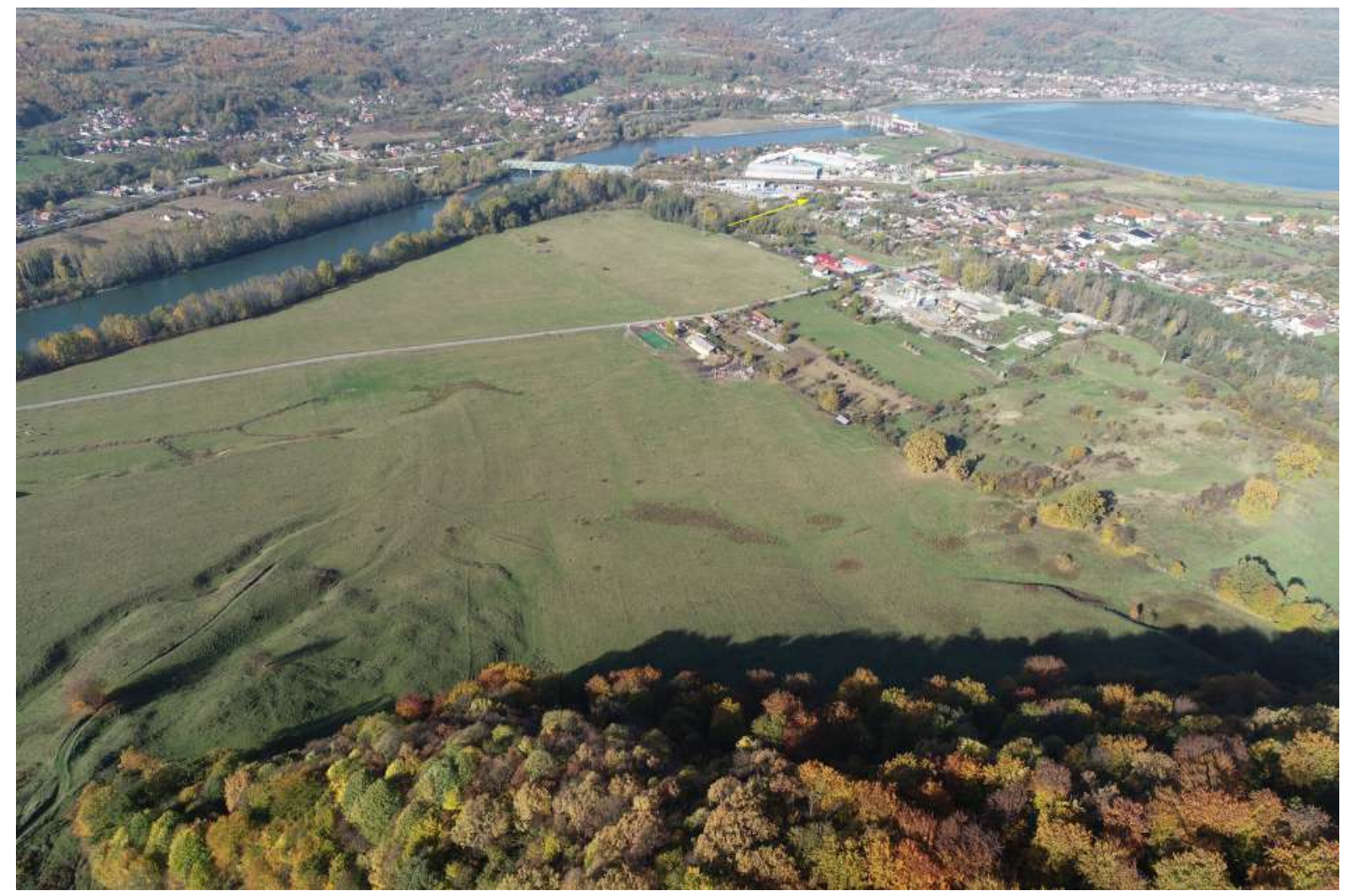

16.5. Sânbotin (Castra Traiana), fotografie oblică din dronă, vedere dinspre Sud-Est (noiembrie 2020).

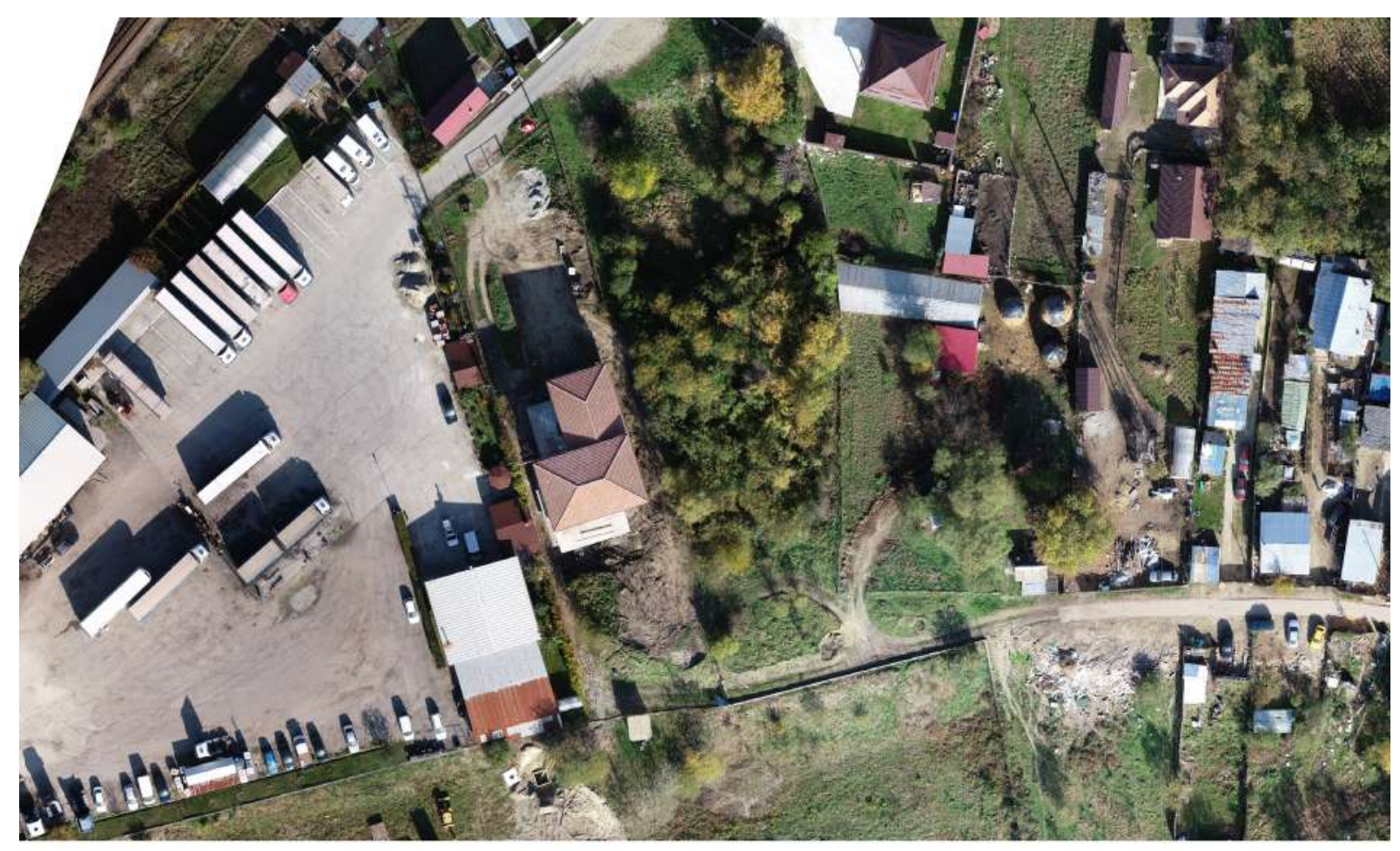

$0 \quad 10 \quad 20 \mathrm{~m}$

16.6. Sânbotin (Castra Traiana), ortofotoplan dronă. 


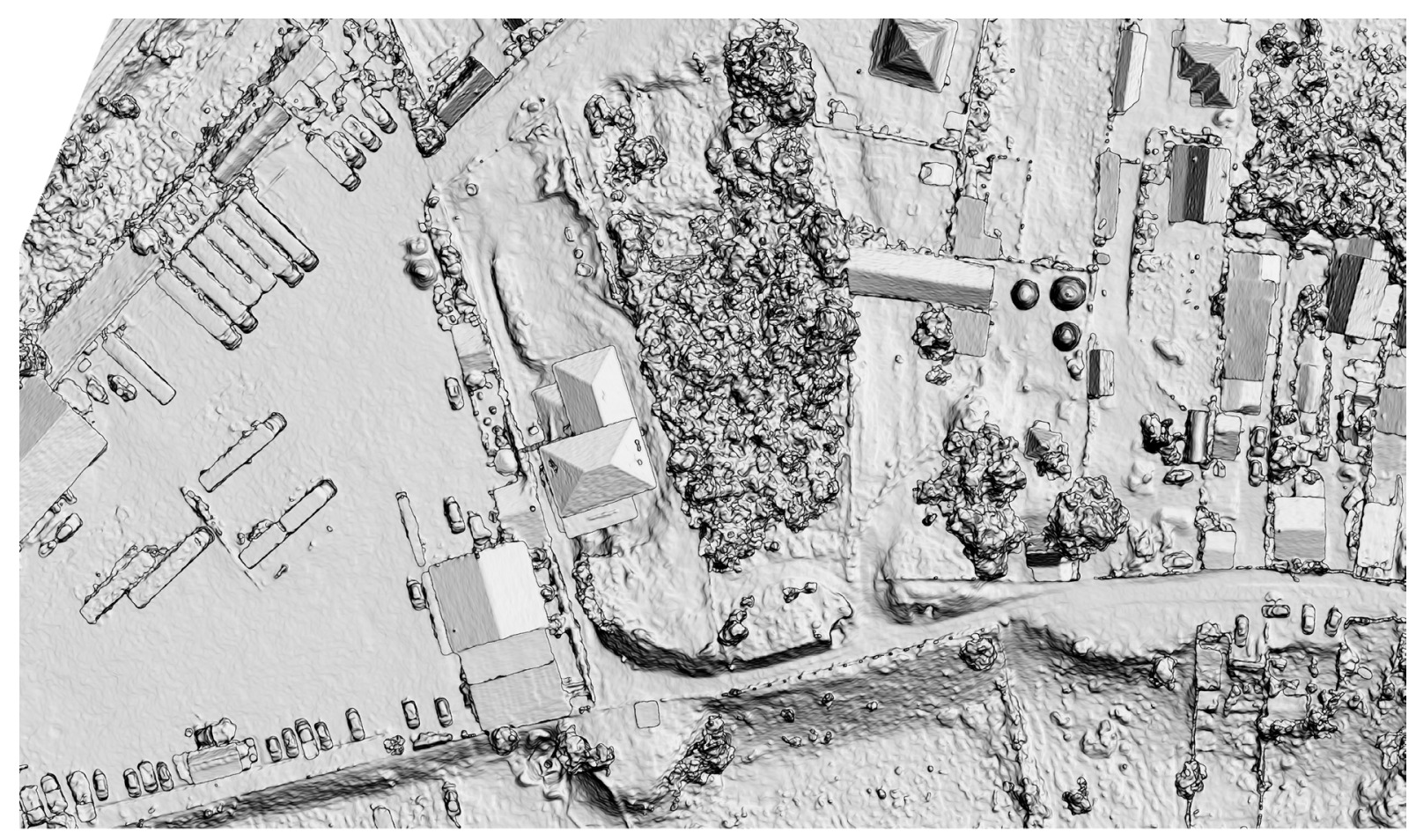

$0 \quad 10 \quad 20 \mathrm{~m}$

16.7. Sânbotin (Castra Traiana), model digital umbrit (hillshade).

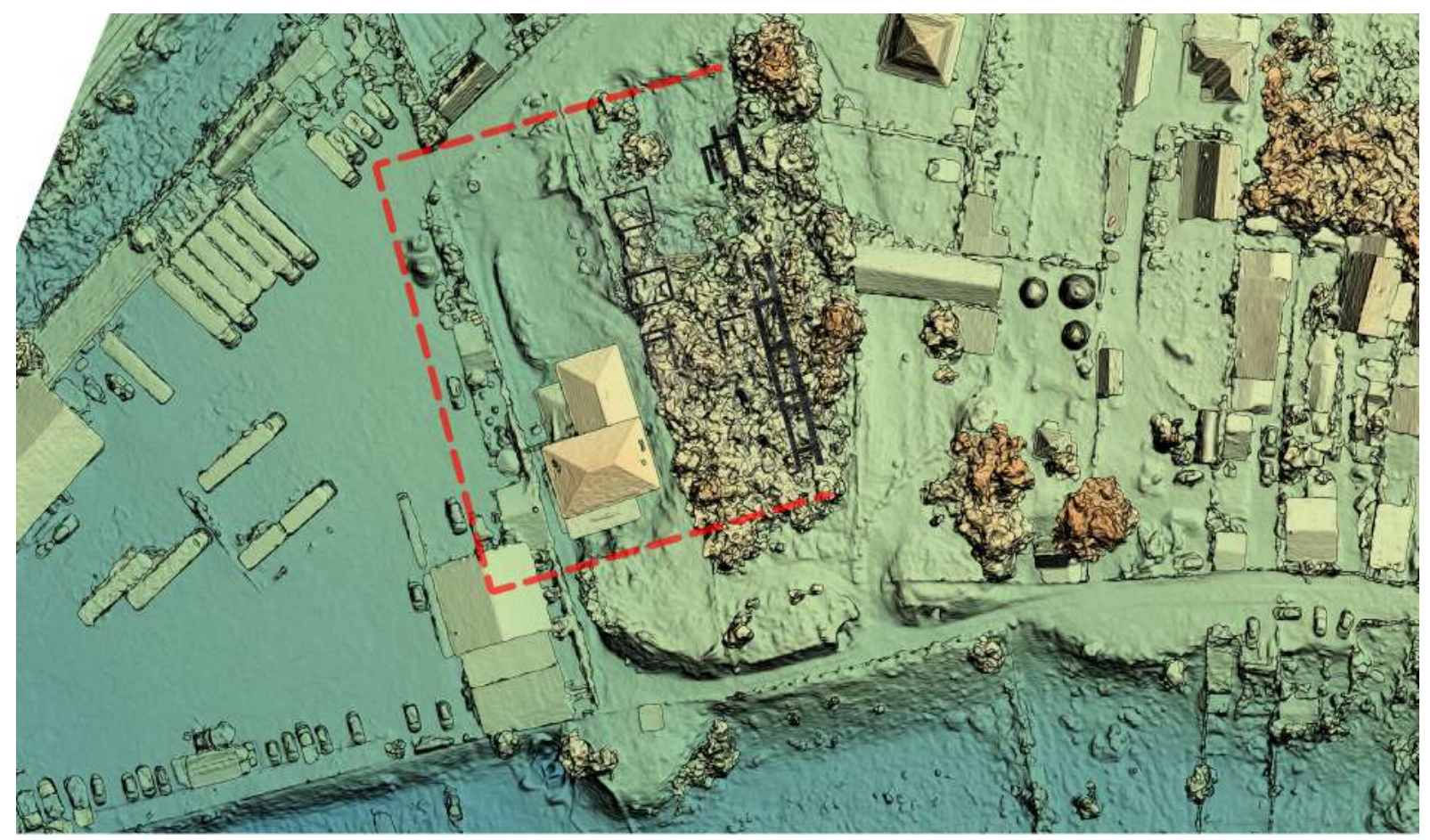

$1020 \mathrm{~m}$

16.8. Sânbotin (Castra Traiana), suprapunerea planului incintei de est (Bogdan-Cătăniciu 1997, fig. 35) pe modelul digital al terenului. 
17. Stolniceni (Buridava, Papirul Hunt, Col. II, 28; Tabula Peutingeriana VII, 4)

Râmnicu Vâlcea, jud. Vâlcea (RAN: 167561.01; VL-I-s-A-09580)

Existența unui castru de dimensiuni mici, $60 \times 60 \mathrm{~m}$ (burgus?), a fost presupusă de D. Tudor în punctul „Conacul Boroneasa". Punctul este situat la Sud de fostul sat Stolniceni (fig. 17.1 -17.8), pe teritoriul actual al municipiului Râmnicu Vâlcea, pe o terasă înaltă, aflată pe malul drept al râului.

Informațiile epigrafice atestă activitatea cohortelor I Hispanorum (papirul Hunt - Buridavae in vexillatione), I Brittonum (IDR II 560, CORSMB - I Augusta Nerviana Pacensis milliaria Brittonum sau cohors I milliaria Brittonum, identitatea celor două unități nefiind încă pe deplin stabilită), II Flavia Bessorum (IDR II 561-562). De asemenea, a fost atestat material ceramic ştampilat al celor trei legiuni ale Moesiei Inferior (V Macedonica, I Italica, XI Claudia), precum 85 de cărămizi sau țigle cu ștampila $P$ (edites) S(ingulares), cel mai probabil fiind vorba de garda guvernatorului Moesiei Inferior, deși o posibilă prezență a procuratorului presidial al Daciei Inferior la Buridava nu poate fi cu totul exclusă.

În cursul săpăturilor efectuate de Gh. Bichir în vicus-ul militar, au fost descoperite urmele unei așezări civile importante, dar ipoteza existenței unei fortificații nu

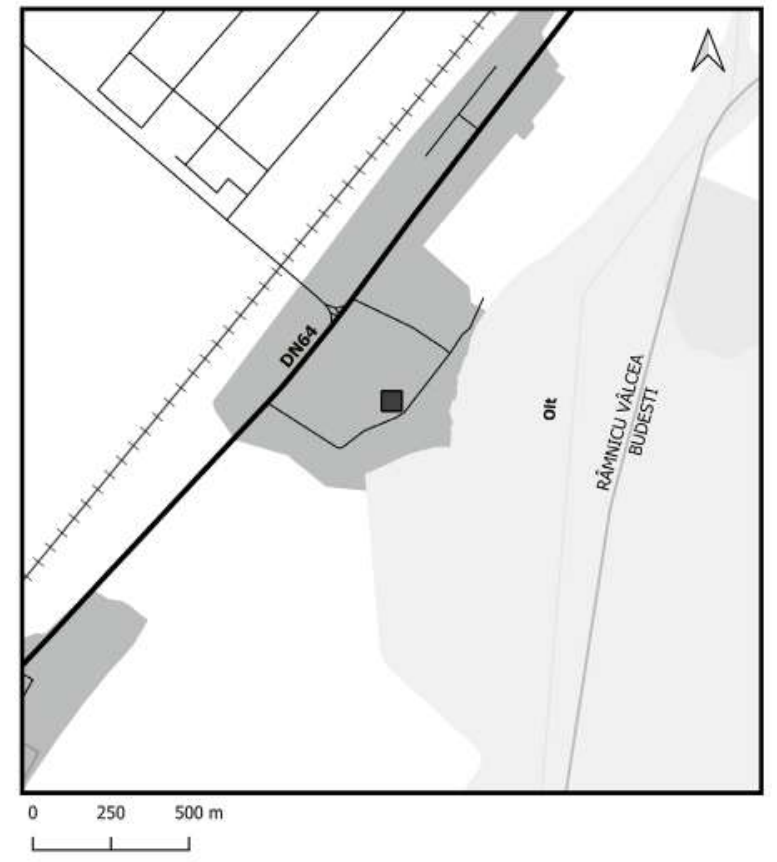

17.1. Stolniceni (Buridava), localizarea sitului. a putut fi confirmată. În cursul acestor săpături a fost cercetată una dintre cele mai mari și bine păstrate clădiri din Dacia Inferior. Aceasta cuprindea numeroase camere cu elemente specifice îmbăierii, care au aparținut fie unei băi foarte mari, fie unei clădiri impresionante (praetorium consularis vel procuratoris?) care avea integrată și o baie.

Pe baza fotografiilor aeriene, Ioana Bogdan-Cătăniciu a identificat amprenta unui posibil amphitheatrum castrense. Oricum dimensiunile reduse ale fortificației presupuse ar fi fost neobişnuite pentru o prezență militară masivă, mai ales în epoca traianică (Fig. 17.2). Fortificația din primii ani ai cuceririi romane este posibil să fie în apropierea fortificației dacice de la Ocnele Mari.

Bazându-se pe dovezile epigrafice, D. Tudor a dezvoltat teoria conform căreia sediul guvernatorului Moesia Inferior a fost aşezat în această zonă între cele două campanii dacice ale lui Traian. Întrucât săpăturile au fost efectuate în principal de către echipele de salvare în mare grabă, iar într-o parte situl a fost distrus de construcții moderne, nu au putut fi obținute detalii semnificative pentru nivelurile romane timpurii.

Bibliografie: TIR L 35, 68-69; Tudor 1968, 311; Tudor 1978, 214-217, nr. 5, 270, nr. 8; Vlădescu 1983, 90-91, nr. 12; Bichir, Gh. şi Bardaşu, P. 1983. Materiale şi cercetări arheologice. A XV-a Sesiune anuală de rapoarte, Braşov, București: Editura Academiei Române: 336-343; Bichir, Gh. 1985. Centrul militar roman de la Buridava. Thraco-Dacica 6: 93-104; Bichir, Gh., Sion A. și Bardaşu, P. 1992. Aşezarea de la Stolniceni, Buridava, jud. Vâlcea. Materiale şi cercetări arheologice. A XVII-a Sesiune anuală de rapoarte. Ploieşti 1983. Bucureşti: Editura Academiei Române: 255-268; Gudea 1997, 88-89, nr. 74; Gudea 2005, 495, nr. VII. B. 5; Marcu 2009, 242-243, nr. 72. 


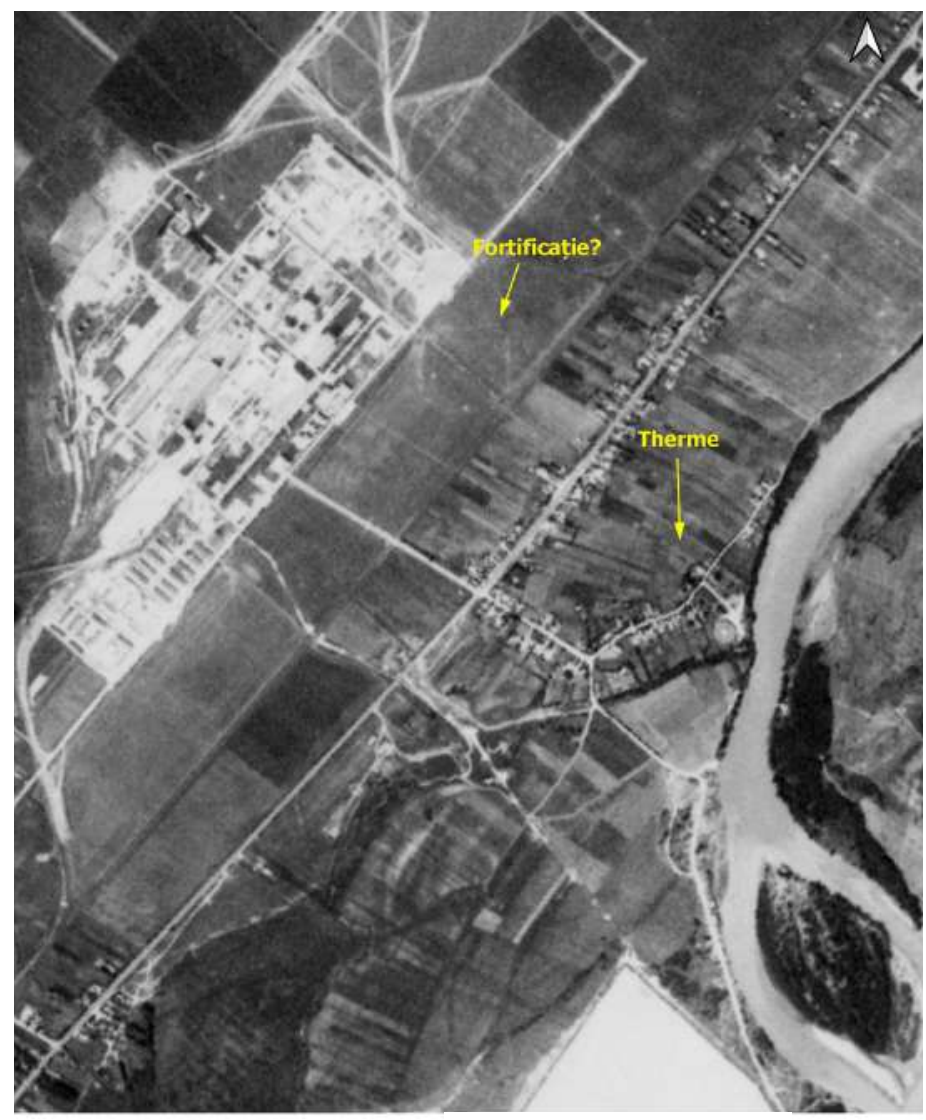

$0 \quad 100 \quad 200 \quad 300 \mathrm{~m}$

17.2. Stolniceni (Buridava), localizarea sitului, poză declasificată satelit Corona 1966 (1036-2139 Fore; Aug 18, 1966_Center for Advanced Spatial Technologies, University of Arkansas/U.S. Geological Survey).

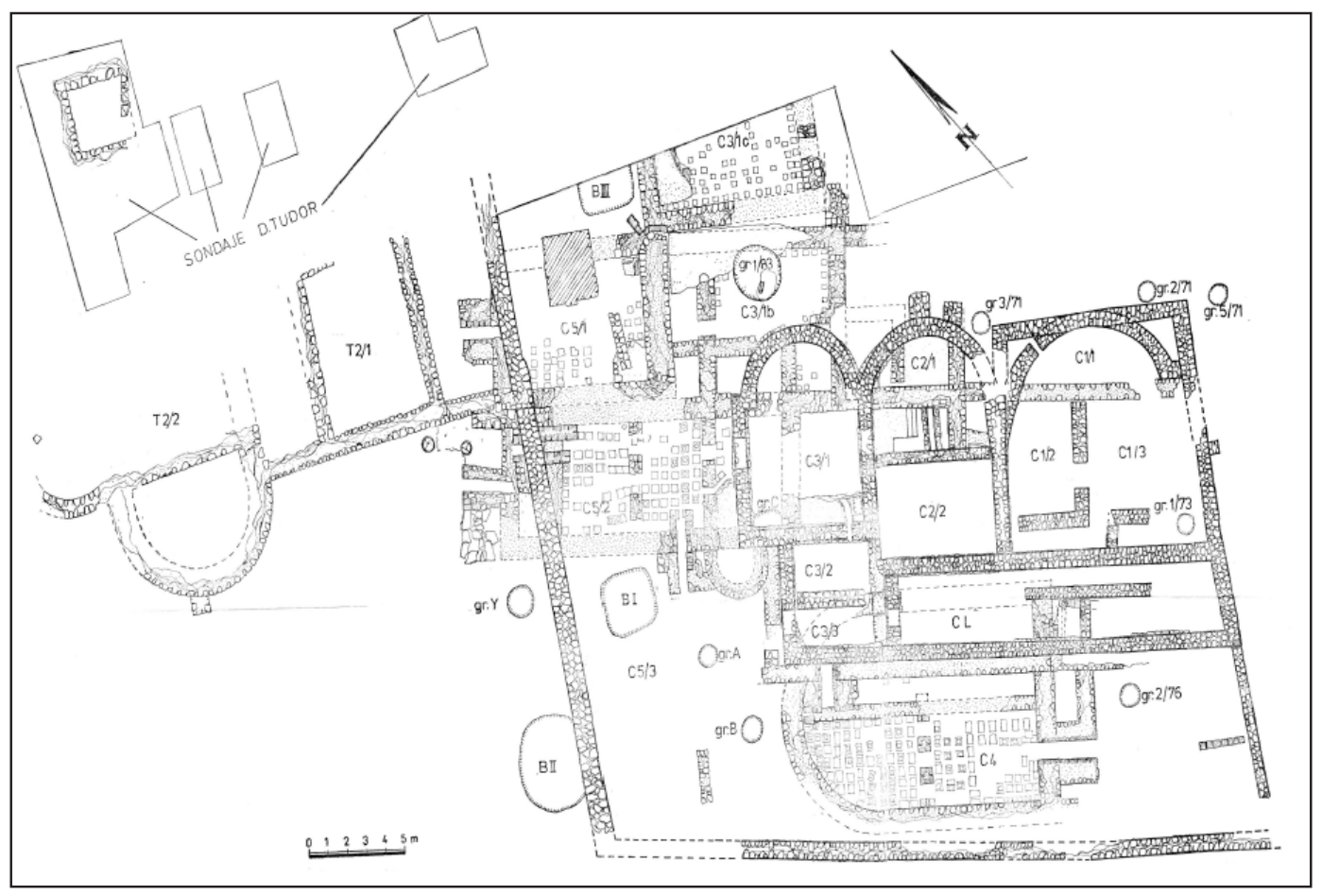

17.3. Stolniceni (Buridava), planul presupuselor băi (Bichir et al. 1992, 257, fig. 1). 


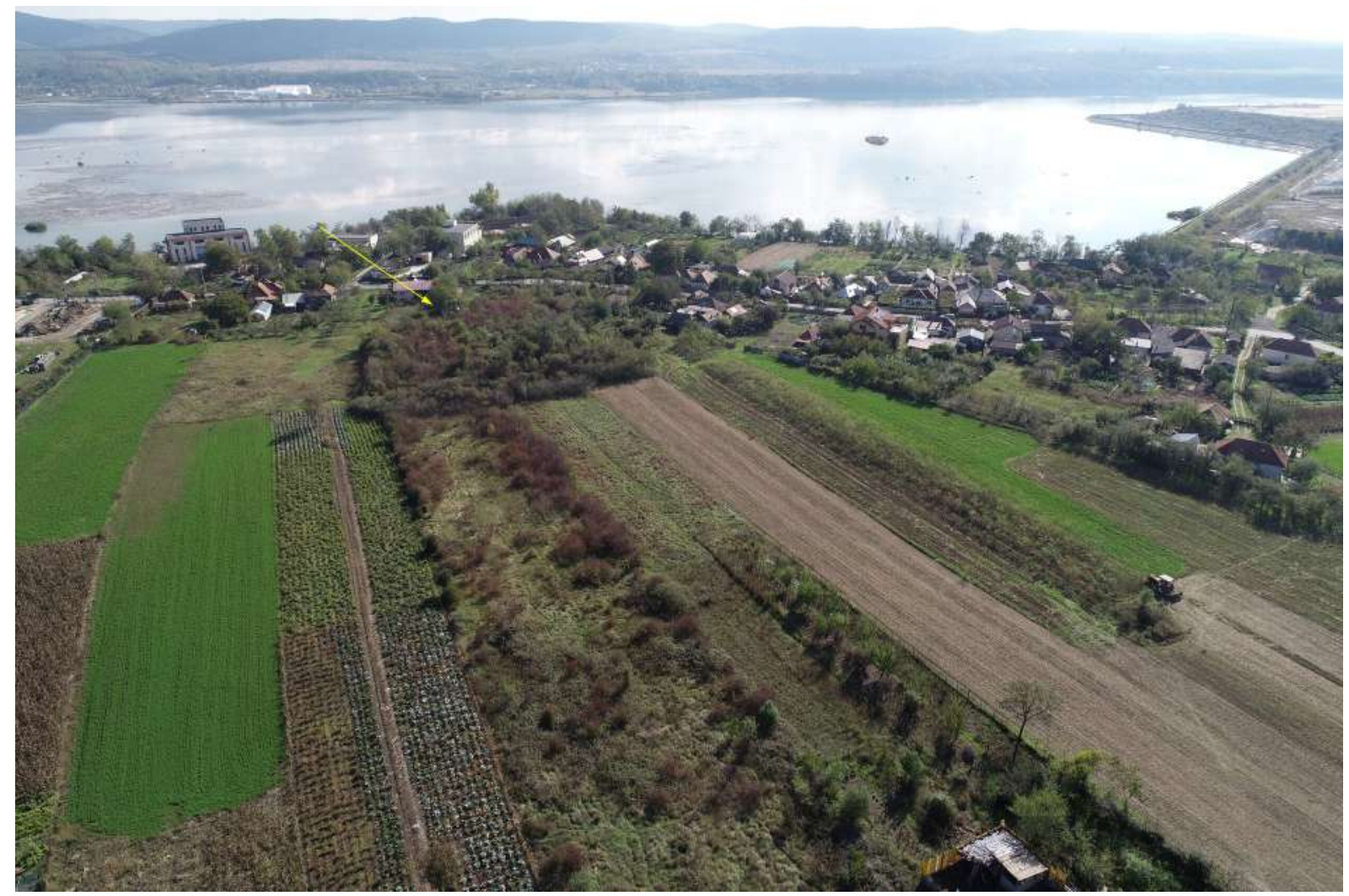

17.4. Stolniceni (Buridava), fotografie oblică din dronă, vedere dinspre Nord-Vest (octombrie 2020).

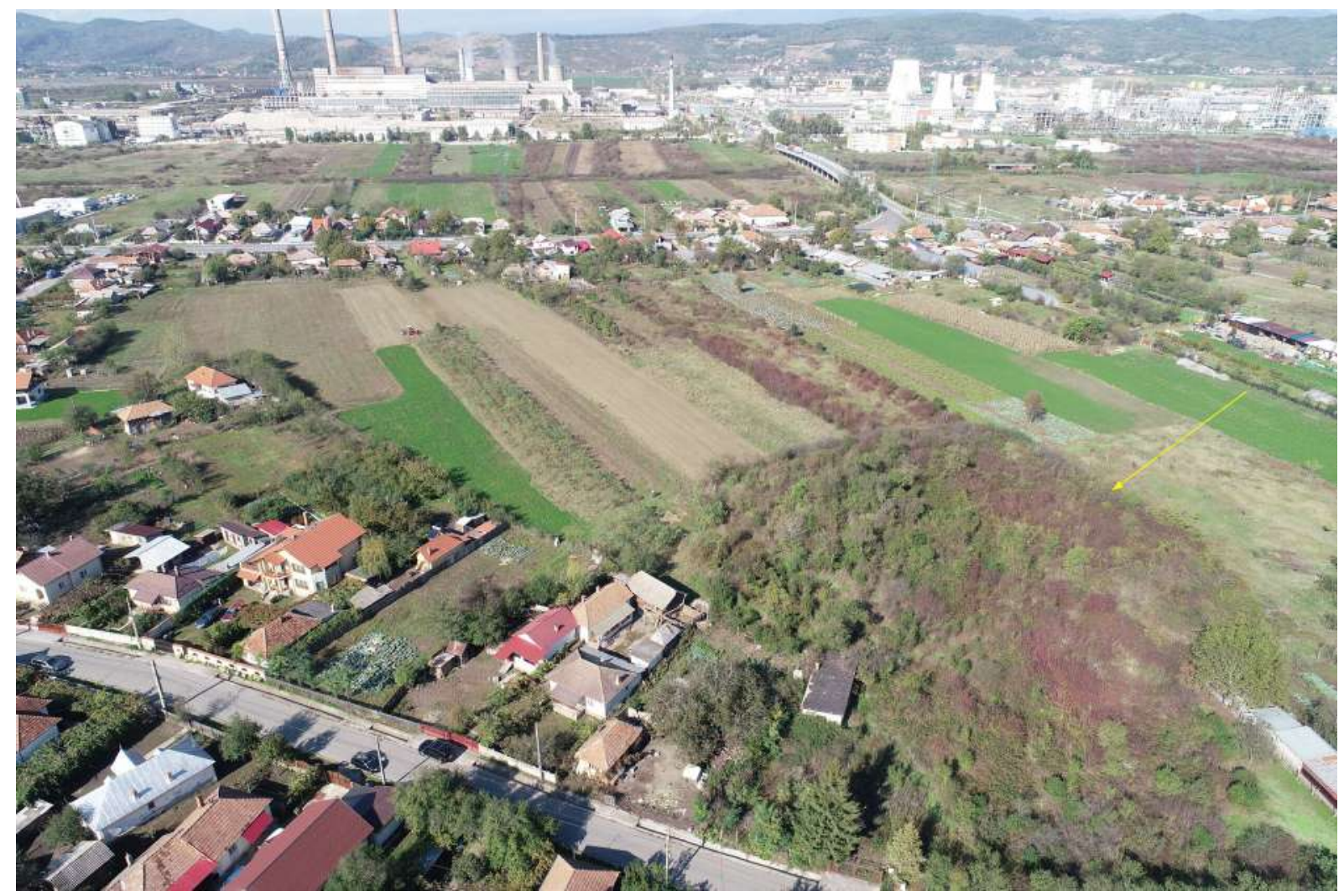

17.5. Stolniceni (Buridava), fotografie oblică din dronă, vedere dinspre Sud-Est (octombrie 2020). 


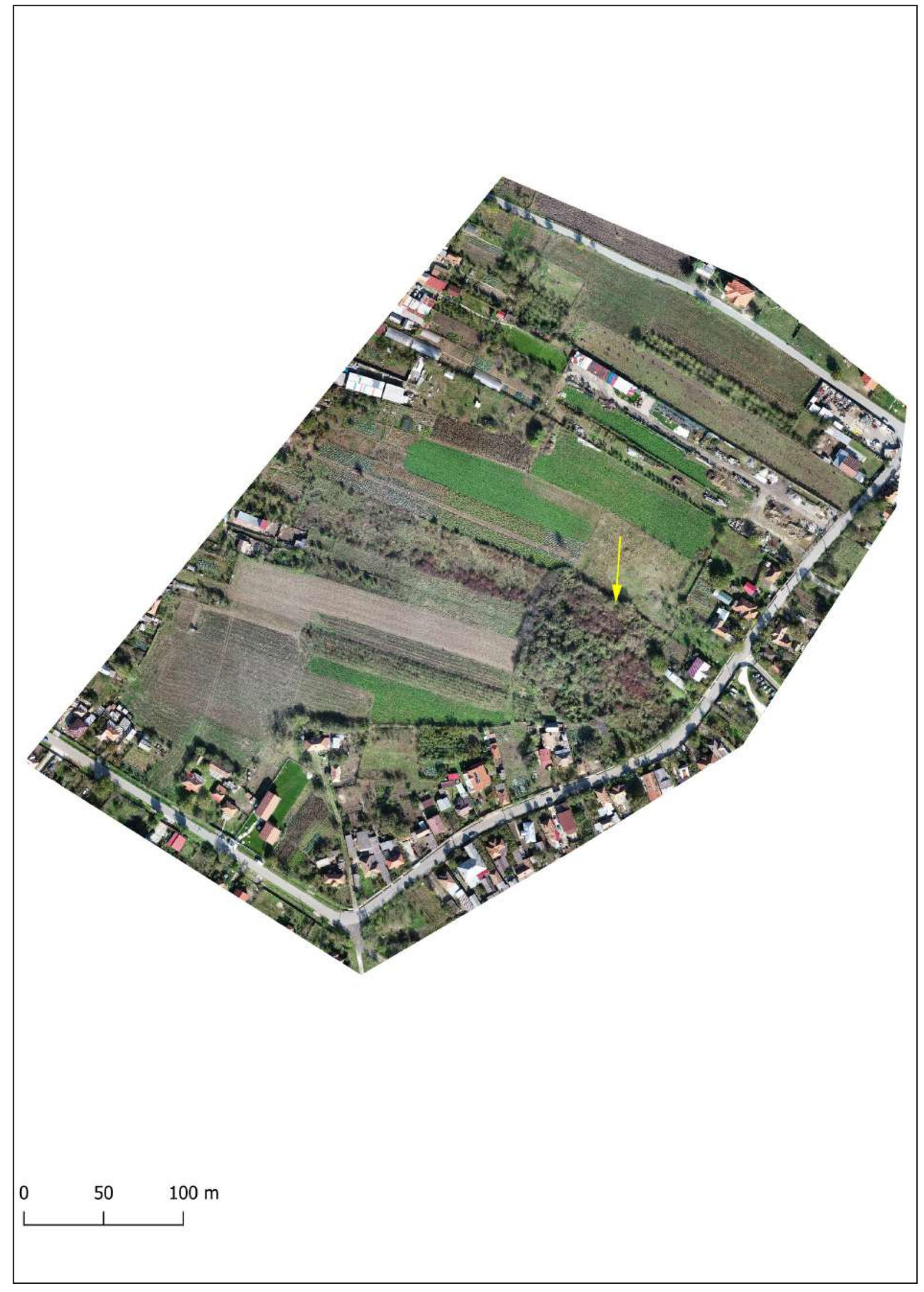

17.6. Stolniceni (Buridava), ortofotoplan dronă. 


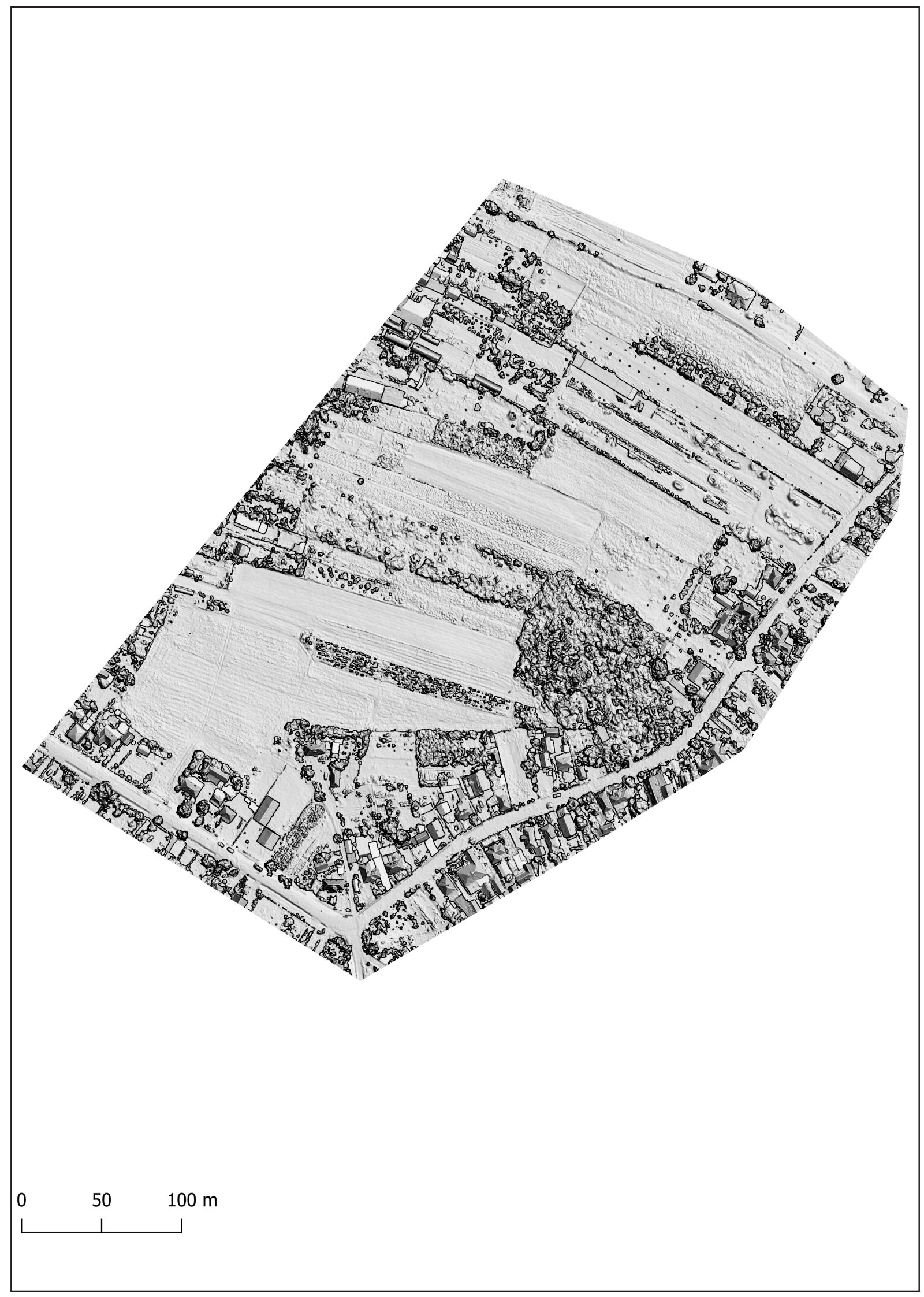

17.7. Stolniceni (Buridava), model digital umbrit (hillshade). 


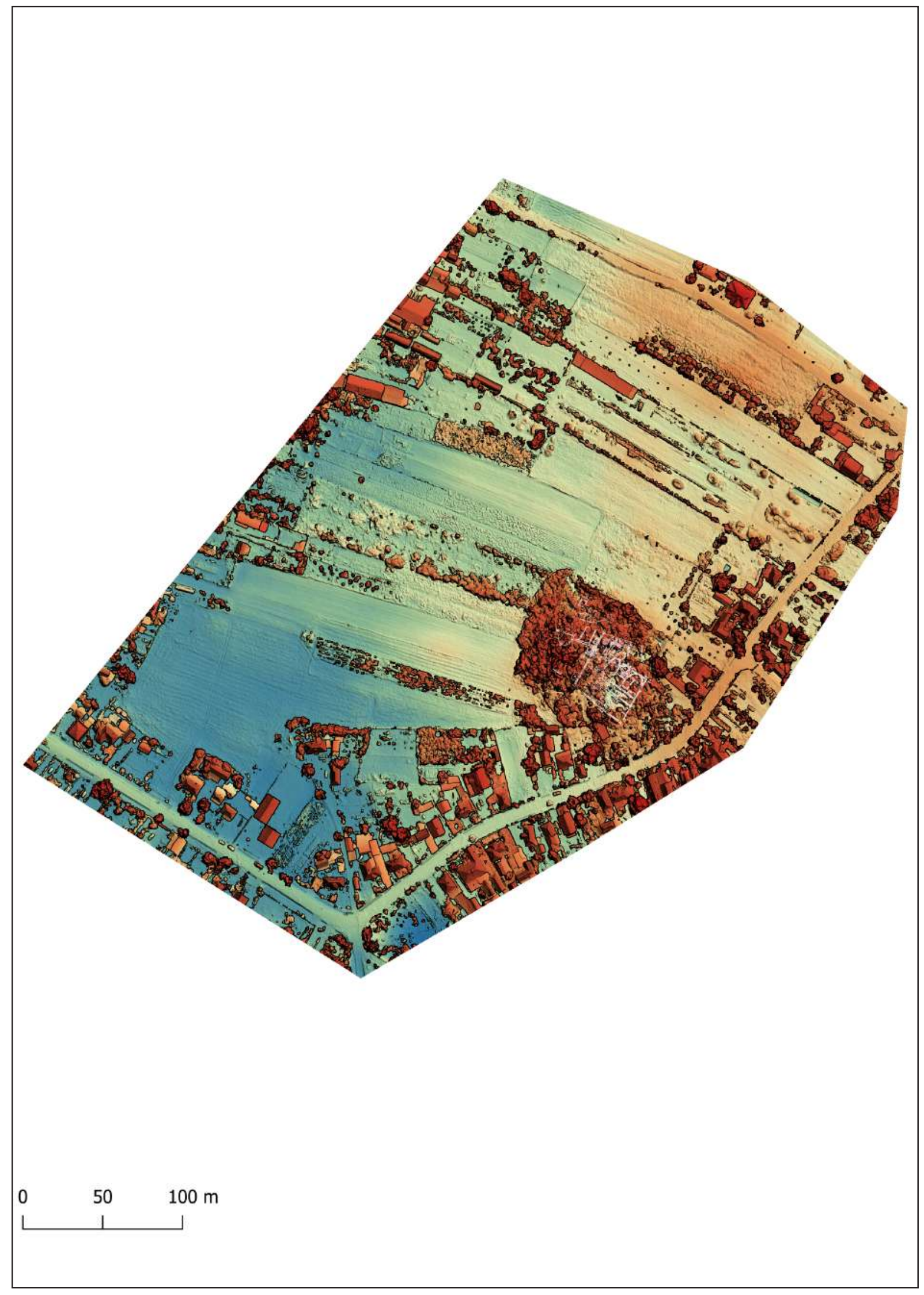

17.8. Stolniceni (Buridava), suprapunerea planului băilor (Bichir et al. 1992, 257, fig. 1) pe modelul digital al terenului. 


\section{Ioneştii Govorii (Pons Aluti, Tabula Peutingeriana VII, 4)}

Com. Ioneşti, jud. Vâlcea (RAN: 170523.01; VL-I-m-B-09545)

Un posibil castru auxiliar de pământ (fig. 18.1 și 18.2), situat la Est de localitatea actuală, pe malul drept al râului a fost semnalat de Gr. Tocilescu. Săpături arheologice de salvare au fost întreprinse de Ioana Bogdan-Cătăniciu în anul 1975. Dintre descoperirile arheologice cele mai relevante amintim o ștampilă a cohortei III Gallorum (IDR II 555), precum și un tezaur monetar, a cărui descoperire a fost localizată într-un presupus turn de Nord-Vest al castrului, aflat sub un strat de arsură. Ceea ce dintr-un prim sondaj părea un zid de incintă s-a dovedit a fi colțul unei clădiri cu absidă aparținând unui edificiu încălzit cu sistemul de tip hypocaustum. Este posibil ca o fortificație să fi funcționat în vecinătatea zonei sondate!

Bibliografie: TIR L 35, 47; Mitrea, B. 1965. Descoperiri recente şi mai vechi de monede antice şi bizantine în Republica. Socialistă România, Studii şi cercetări de istorie veche 16, 3: 605-618 (p. 614); Tudor 1968, 290-291; Bogdan-Cătăniciu, I. 1977. Nouvelles recherches sur le limes du Sud-Est de la Dacie. in: Jenö Fitz (ed.) Limes. Akten des XI. Internationalen Limeskongresses. Budapest: Akadémiai Kiadó: 333-353; Tudor 1978, 286-287, nr. 29; Vlădescu 1983, 90, nr. 11; Vlădescu 1986, 42-43, 116 n. 183; Gudea 1997, 87-88, nr. 73; Petolescu 2002, 106; Dudău 2006, 70, nr. 18; 116; Marcu 2009, 212, nr. 55; Valentin, D. 2020. Un antoninian din tezaurul de la Ioneştii Govorii, jud.Vâlcea, Buridava 14: 189-195.

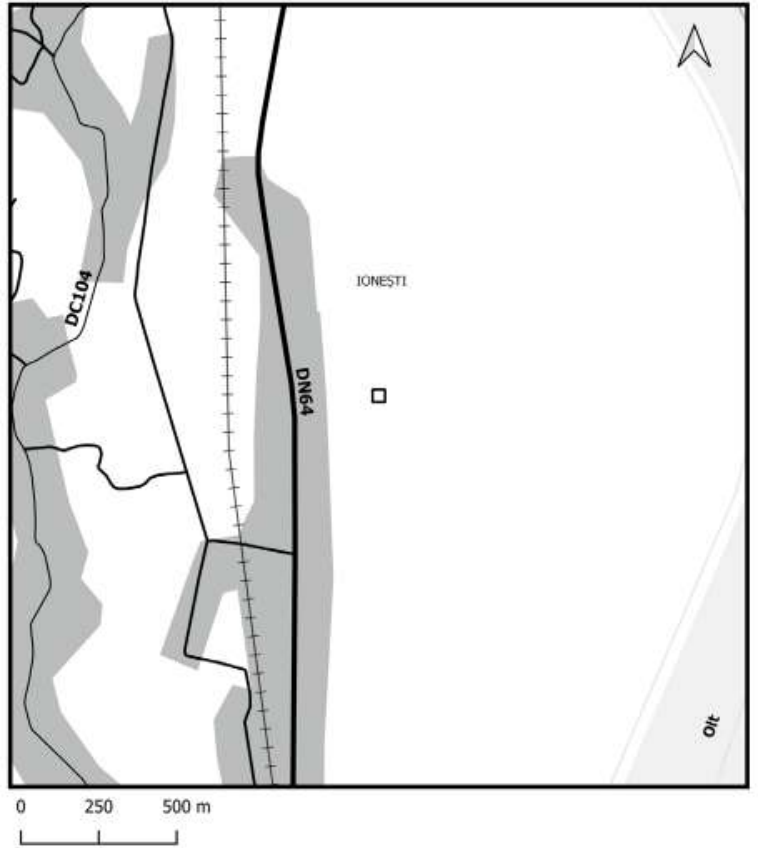

18.1. Ionești, localizarea presupusă a sitului.

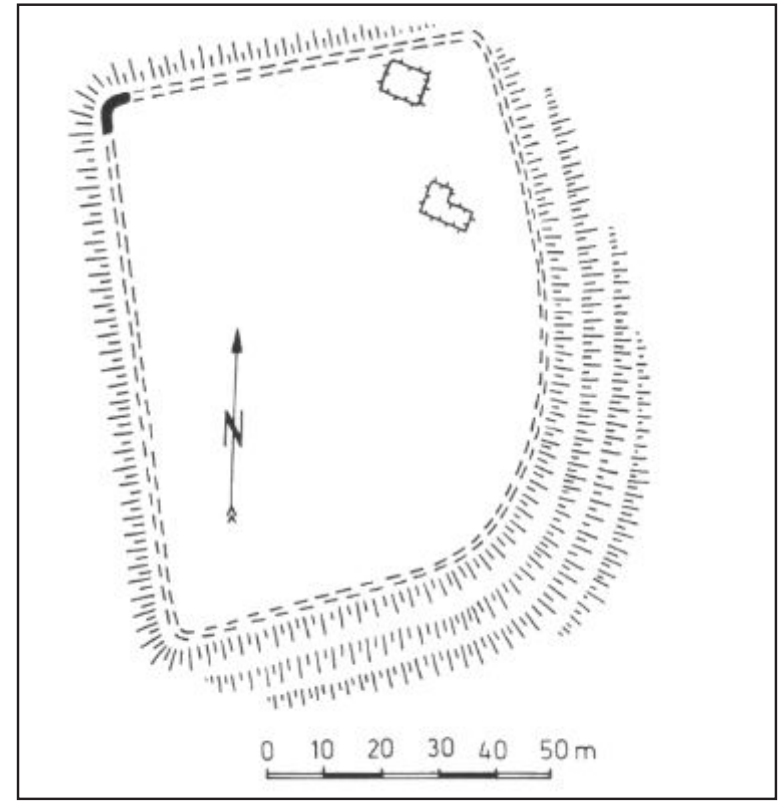

18.2. Ioneşti, planul sitului (Gudea 1997, 88, nr. 73).

19. Drăgășani, cart. Momotești (Rusidava ?, Tabula Peutingeriana VII, 4)

Drăgăşani, jud. Vâlcea.

Fortificația corespunzătoare toponimului Rusidava a fost localizată de unii autori la Momotești, astăzi cartier al oraşului Drăgăşani. Cercetătorii D. Tudor și Cr. M. Vlădescu au acceptat cu unele rezerve această localizare în cartierul Momotești, la $250 \mathrm{~m}$ Est de șoseaua națională și la un kilometru Vest de Olt, în apropierea râului Pesceana (fig. 19.2). Săpăturile unor amatori locali au dus la descoperirea unor urme romane constând în fundații de ziduri, cărămizi, una cu ștampilă (IDR II 554), tuburi de canalizare și diverse artefacte databile în epoca romană (fig. 19.1). Urmele drumului au fost semnalate de Dumitru Tudor la nord de presupusul castru și așezarea civilă.

Orice urme de locuire romană au dispărut între timp de pe teritoriul acestei localități.

Bibliografie: Tudor 1978, 298; Ciucă, I. M., Predescu, B. și Ciucă, I. D. 2005. Priorități istorice oltene şi romănățene, Parohia Câmpu-Mare, județul Olt: 47-50. 


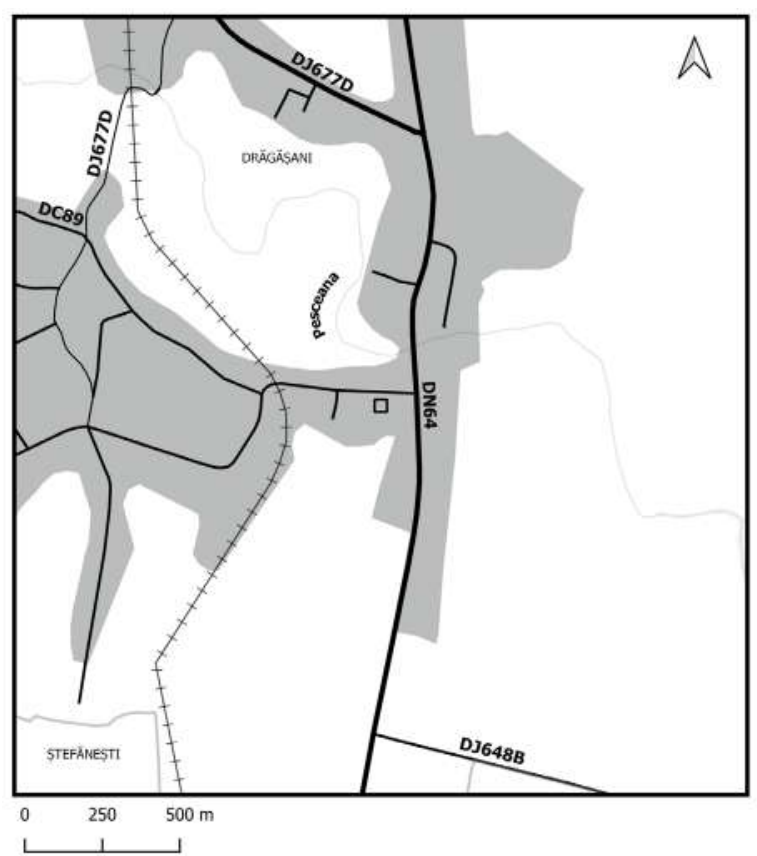

19.1. Drăgășani, localizarea presupusă a sitului.

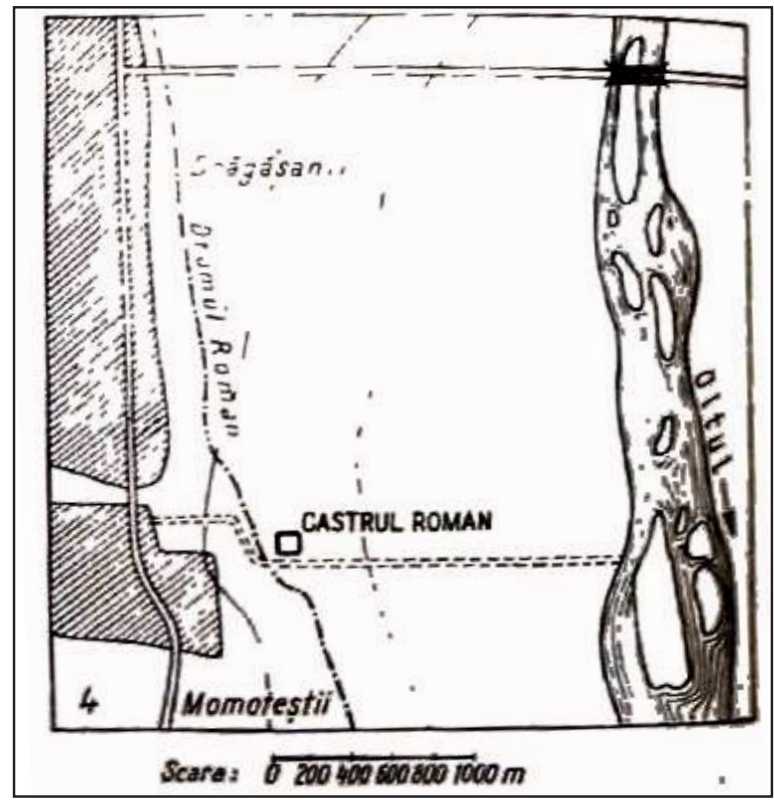

19.2. Drăgășani, localizarea presupusă a sitului (Tudor 1978, 316, fig. 92/4).

20 Enoşeşti (Acidava, Tabula Peutingeriana VII, 4)

Piatra Olt, jud. Olt (RAN: 128114.05; OT-I-s-A-08526)

Castrul (fig. 20.1 și 20.2) a fost construit pe un bot de deal, situat la $20 \mathrm{~m}$ deasupra luncii Oltului, între Piatra Olt și Enoșești, în punctul denumit în a doua parte a secolului XIX, „Cetatea lui Traian”. În cea mai mare parte a fost distrus în anul 1872, în timpul construirii căii ferate Slatina - Piatra Olt. Câteva sondaje au fost făcute de către Dimitrie Butculescu în anul 1881. Alte sondaje au fost efectuate de Cr. M. Vlădescu și Gh. PoenaruBordea în anul 1976. Pe baza acestor cercetări a fost presupusă existența a două faze: Primul castru de lemn și pământ a fost probabil construit în timpul lui Traian (ştampilă cohors I Flavia Commagenorum - IDR II 551, respectiv ştampilă cohors I Thracum? - AE 1989, 630). A doua fortificație pare să fi fost construită din piatră și cărămidă.

La Vest de castru au fost identificate urmele unei aşezări civile, un posibil vicus militar. Un tezaur monetar a fost descoperit în interiorul castrului în anul 1913, compus din 152 de denarii (Domitian - Caracalla), așezați într-un vas de lut.

Bibliografie: TIR L 35, 16; Tudor 1968, 264265; Tudor 1978, 258, 287 fig. 79/3; Vlădescu, C. M. şi Poenaru Bordea, Gh. 1978, Cercetări

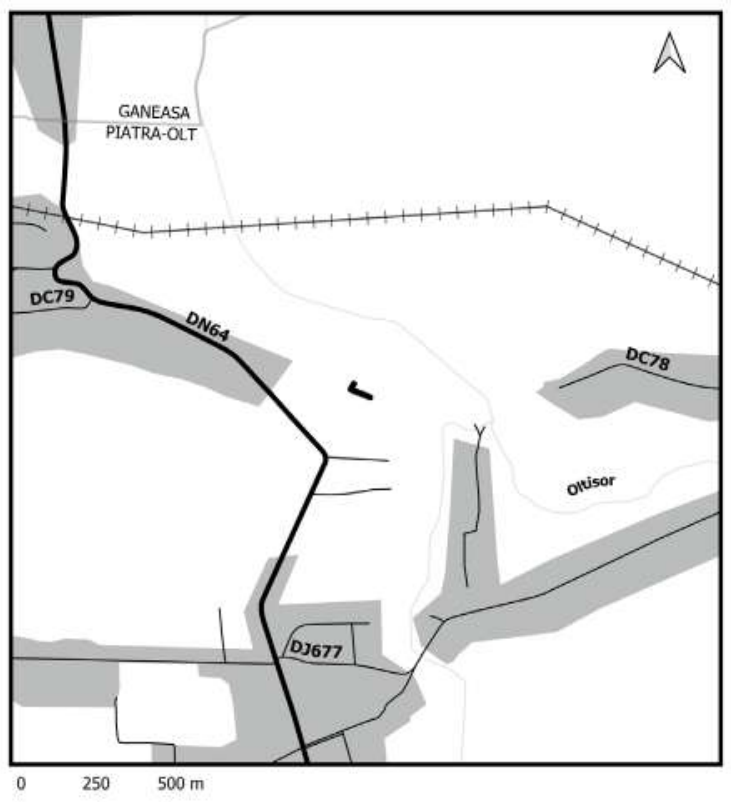

20.1. Enoșești, localizarea sitului. arheologice în castrul roman de la Acidava, satul Enoșești, comuna Piatra Olt, județul Olt, Studii şi materiale de muzeografie şi istorie militară 11: 137-142; Vlădescu 1983, 89-90, nr. 9; Popilian, Gh. și Ciucă, I. 1986. La céramique sigillée d'importation d'Acidava. Dacia, N.S. 30: 167-172; Barnea A. și Ciucă, I. 1989. O nouă unitate militară romană la Acidava, Studii şi cercetări de istorie veche şi arheologie 40, 2: 
147-150; Popilian, Gh. și Ciucă, I. 1993: Ceramica de tip terra sigillata de import descoperită la EnoşeştiAcidava (jud.Olt). Arhivele Olteniei, Serie Nouă 8: 29-42; Gudea 1997, 86-87, nr. 71; Bogdan-Cătăniciu, I. 1997, 66-67; Petolescu 2002, 121-122; Gudea 2005, 494, nr. VII. B. 4; Dudău 2006, 64, nr. 7; 110; Marcu 2009, 205, nr. 49; Botiș, F-O., 2020. Some remarks on the pottery workshops areas in the military vicus at

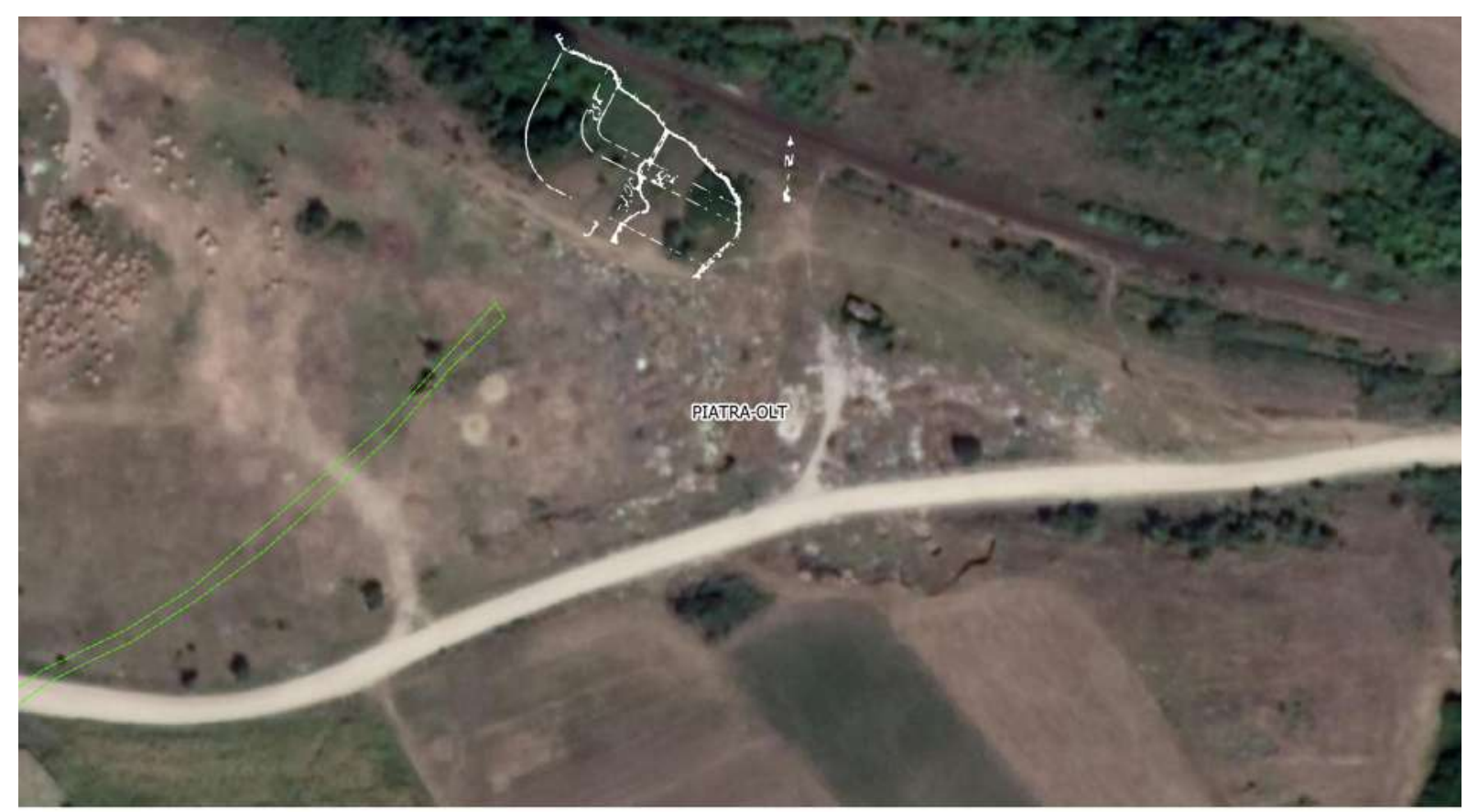

20.2. Enoșești, suprapunerea planului (Tudor 1978, 258, fig. 79/3) pe ortofotoplan Google Earth.

Acidava-Enoșești Roman Fort, Revista CICSA 6: 79-96.

21. Reşca (Romula, Tabula Peutingeriana VII, 4)

Com. Dobrosloveni, jud. Olt (RAN: 126754.01.02; OT-I-m-A-08527.02)

Satul Reșca suprapune în cea mai mare parte un complex (fig. 21.1 - 21.8) cu urmele a trei presupuse instalații militare romane, situate în centrul satului actual, în punctele „Cetate” (A), „Biserica Veche” (B) şi „Dealul Morii” (C). Unii cercetători susțin existența doar a două fortificaţii (fig. 21.1 - 21.4). Săpături arheologice au fost efectuate de D. Tudor, Cr. M. Vlădescu 1968-1976, M. Negru 2003 - prezent).

Castrul auxiliar A este dreptunghiular, cu dimensiunile de $216 \times 182 \mathrm{~m}$. Au fost documentate două faze de construcție ale acestei fortificații. Primul castru era construit din palisadă de lemn şi val de pământ. Al doilea castru, presupus a fi fost construit în timpul lui Hadrianus, avea zid de cărămidă, gros de aproape doi metri.

Castrul auxiliar B are plan pătrat $(100 \times 100 \mathrm{~m})$. Castru auxiliar C avea un plan dreptunghiular.

Ștampilele imprimate pe materialul ceramic de construcție aparțin unui număr impresionant de trupe: legiunile XI Claudia p. f., V Macedonica; legiunile VII Claudia Philippiana (IDR II 327; ILD 136) şi XXII Primigenia Philippiana (IDR II 326; ILD 135), numerus Syrorum Malvensium, cohors I Flavia Commagenorum (IDR II 382) sau [...]I SAG, încă neidentificată (cohors I sagittariorum?) (ILD 140). Întregul complex militar a început să funcționeze în vremea lui Traian şi a durat până la jum. sec. III p. Chr. sau chiar până la părăsirea provinciei.

Așezarea civilă de la Romula a devenit municipium în timpul lui Hadrianus, fiind apoi atestată colonia Romulensium pe timpul lui Philippus Arabs, în anul 248 p. Chr. (dar făă îndoială promovarea a avut loc mai devreme, vezi în acest sens atestarea coloniei pe sarcofagul lui Aelius Iulius Iulianus, IDR II 357 - fig. 21.7, 21.8), când zidurile orașului au fost reconstruite manu militari (CIL III 8031 = ILS 510 = IDR II 324), folosindu-se Bauvexillationen 
din legiunile XXII Primigenia p. $f$. din Germania superior (AE 1940, $13=$ IDR II 325; AE 1940, 14 = IDR II 326) și VII Claudia p. f. din Moesia superior (AE 1939, 28 = IDR II 327; CIL III 8047 = IDR II 328). Ambele legiuni fuseseră probabil implicate în respingerea atacului carpic din anul $247 \mathrm{p}$. Chr.

Cercetările arheologice recente s-au concentrat în ultimii ani în zona fortificației centrale, fiind publicate mai multe categorii de artefacte.

Bibliografie: Tocilescu 1900: 94-100; Christescu 1937: 199-200; D. Tudor, 1968. Romula, Bucureşti: Meridiane; TIR L 35, 62; Tudor 1968, 342-356; Benea, Doina 1974. O insignă militară romană de la Romula. Oltenia 1: 69-74; Poenaru-Bodea, Gh., Vlădescu, C.M. 1976. Fortificația centrală de la Romula. Studii şi materiale de muzeografie şi istorie militară 9: 3-15; Vlădescu, C.M., Poenaru-Bordea, Gh. 1977. Complexul de fortifificaţii de la Romula în cadrul sistemului defensiv roman de pe Limes Alutanus. Studii şi materiale de muzeografie şi istorie militară 10: 17-23; Vlădescu, C.M., Poenaru-Bordea, Gh. 1977. Le complèxe des fortifications de Romula dans le cadre du système défensif du Limes Alutanus. in: Jenö Fitz (ed.) Limes. Akten des XI. Internationalen Limeskongresses. Budapest: Akadémiai Kiadó: 353-364; Tudor 1978, 297, nr. 38; Speidel, M. P. 1987. Felix legio vestra. A Building Inscription fromRomula-Malva, ZPE 30: 119-122; Vlădescu, C.M. 1981: Masca de paradă de la Romula şi încercarea de recontituire a coifului de cavalerie romană. Studii şi cercetări de istorie veche şi arheologie 32, 2, 195-204; Vlădescu, C.M. 1982: Fortificaţiile romane de la Romula Malva şi problema continuității aşezării. Muzeul Național 6, 123 131; Vlădescu 1983, 85-88, nr. 8; Vlădescu 1986, 34-40; Tătulea, C.M. 1994: Romula-Malva, Bucureşti: Museion; Bogdan-Cătăniciu 1997, 64-66; Gudea 1997, 85-86, nr. 70; Vlădescu, C.M., Stoica, O. şi Amon, L. 1998. Edificii civile şi militare recent descoperite la Romula. Oltenia SN 1: 57-71; Gudea 2005, 493 494, nr. VII. B. 3; Dudău 2006, 130; Marcu 2009, 228-229, nr. 66; Romula. Seria rapoarte arheologice, I. Raport privind cercetările arheologice sistematice din anul 2015, Negru M. și Schuster, C. (ed.), Târgovişte: Cetatea de Scaun, 2016; Negru, M., Gherghe, P. and Amon, L. 2020. Considerations regarding the phases of evolution of the Roman town of Romula, in light of archaeological research at the Central Fortification (2013-2018), Analele Universitatii din Craiova - Seria Istorie 38, 2: 7-18.

Necropola tumulară era situată în Sud-Vest față de incinta orașului, de-a lungul drumului roman care ducea către Sucidava. Cercetări arheologice au fost efectuate între anii 1969-1972, de V. Leahu, iar cele preventive din 2007-2011 de Mircea Negru.

Un alt drum roman a fost semnalat pe direcția Sud-Est, denumit "Drumul lui Traian" (Tudor 1978, 178 fig. 178). În apropierea acestuia a fost descoperit sarcofagul lui Aelius Iulius Iulianus.

$\mathrm{O}$ necropolă din care se disting înmormântări tumulare se poate observa şi la Nord-Vest de satul Reşca, urmând cursul pârâului Potopin. Rezultatele săpăturilor au fost publicate monografic de dată mai recentă (fig. 21.7 și 21.8).

Bibliografie: Babeş, M. 1970. $\mathrm{Zu}$ den Bestattungsarten im nördlichen Flachgräberfeld von Romula. Beitrag zur Grabtypologie des römischen Daziens, Dacia, N.S. 14: 167206; Leahu, V. 1975. Cercetări arheologice în necropola tumulară de la Romula (1969), Cercetări Arheologice 1: 191-215; Babeș, M., Bondoc, D., Nicolae, C. 2020. Necropola plană birituală de la nordul orașului Romula, Craiova:

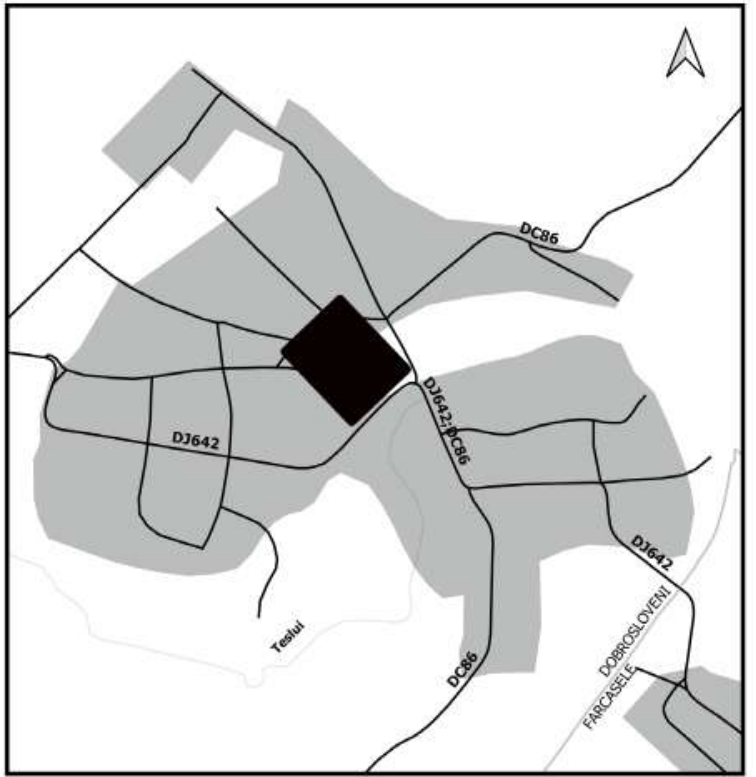

$0 \quad 100200300$ m

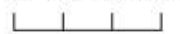

21.1. Reşca (Romula), localizarea sitului. 


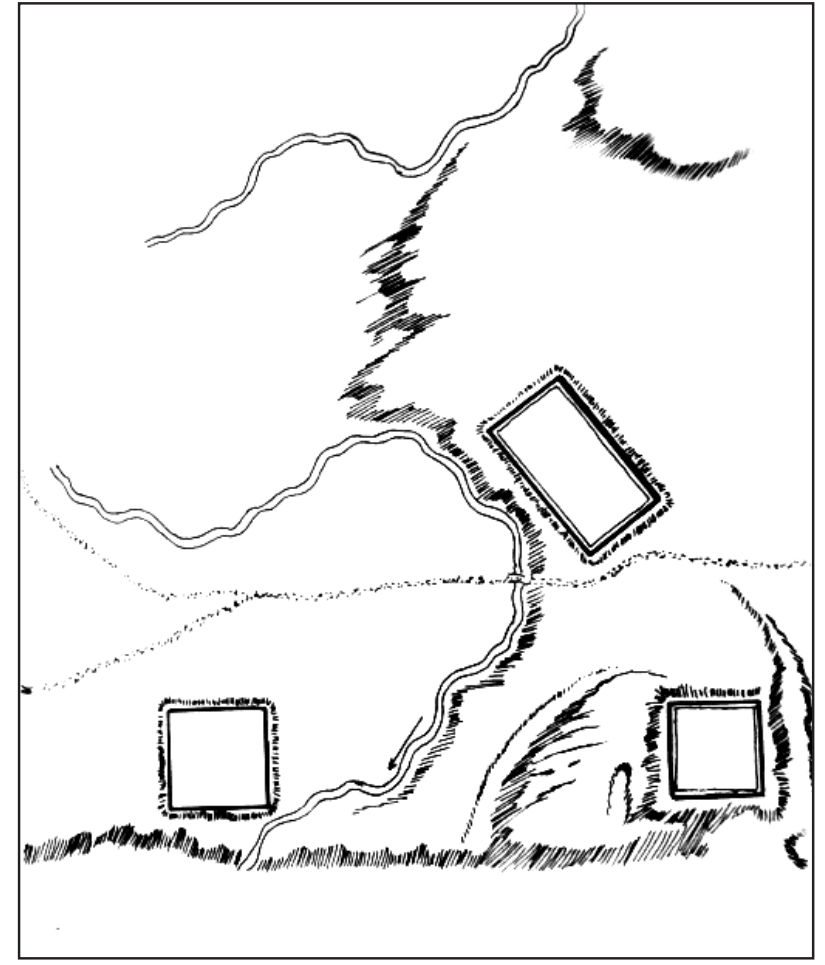

21.2. Reșca (Romula), planul fortificațiilor de la Romula (Marsigli 1726, apud. Tudor 1978, fig. 41.2).

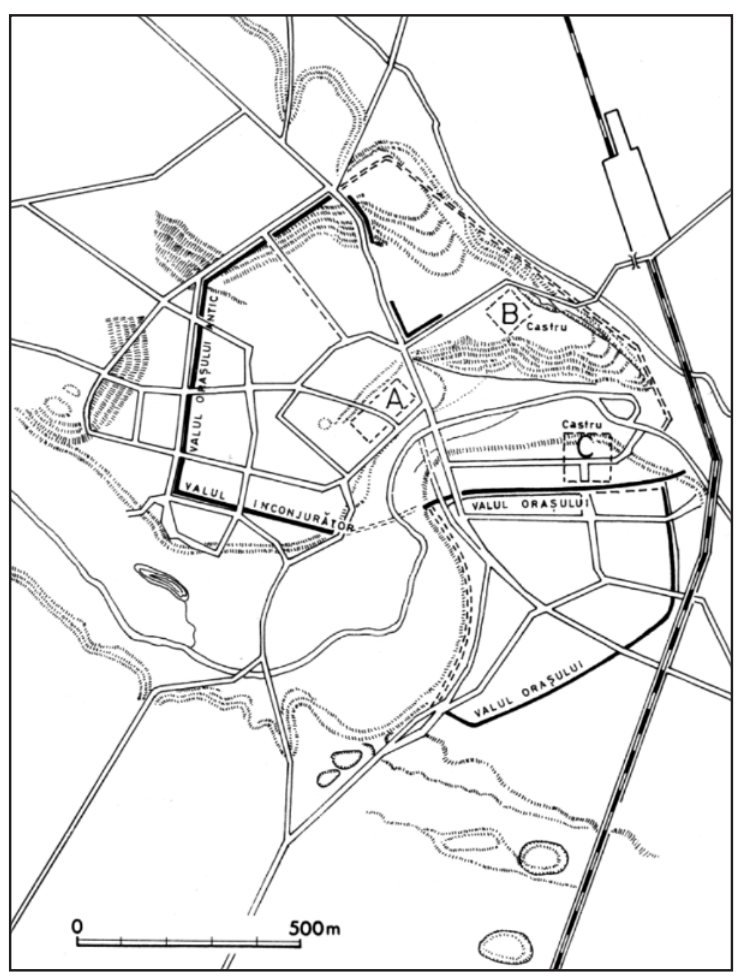

21.3. Reșca (Romula), planul fortificațiilor de la Romula (Tudor 1978, 179, fig. 2).

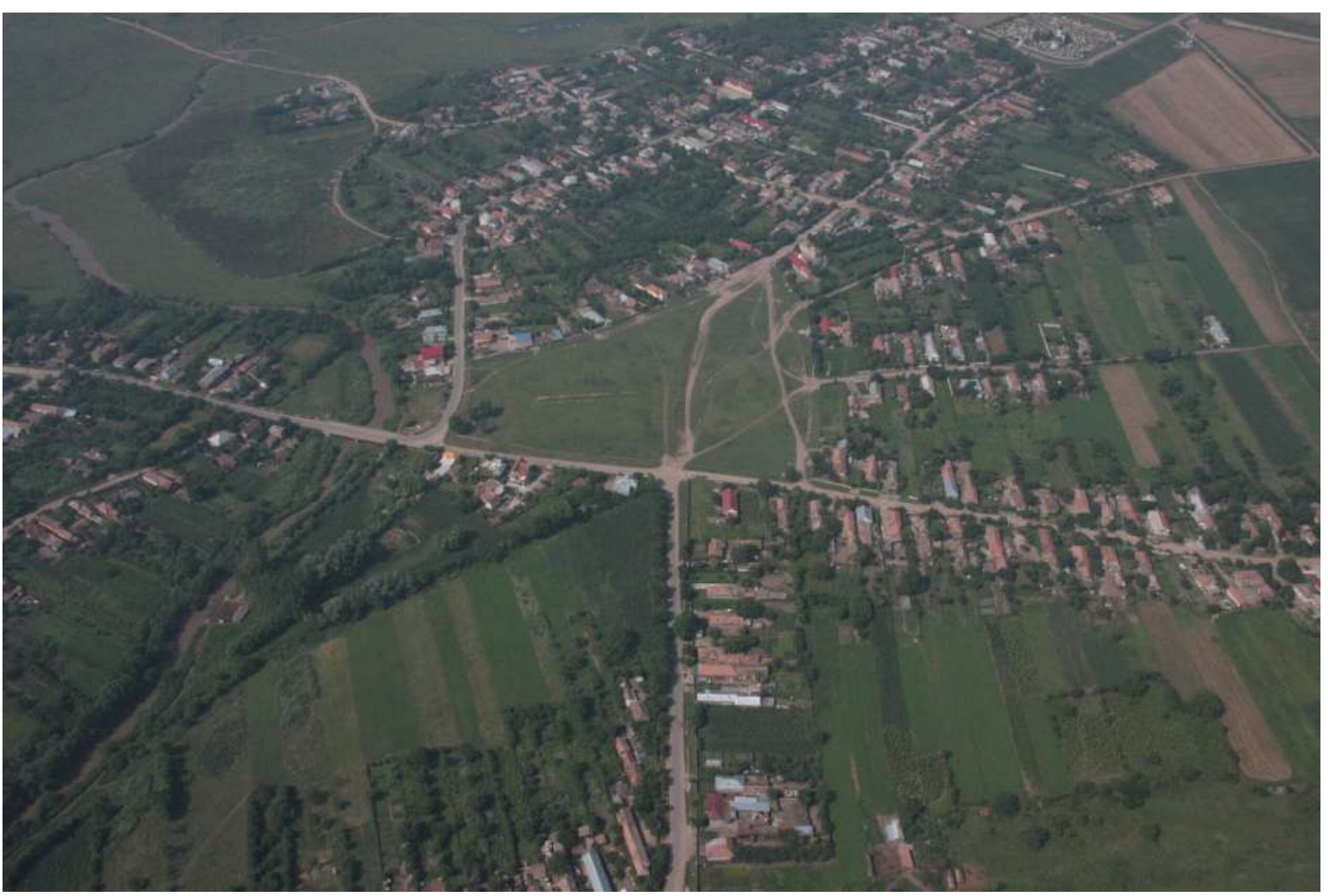

21.4. Reșca (Romula), fotografie oblică aeriană, vedere dinspre est (iulie 2010). 


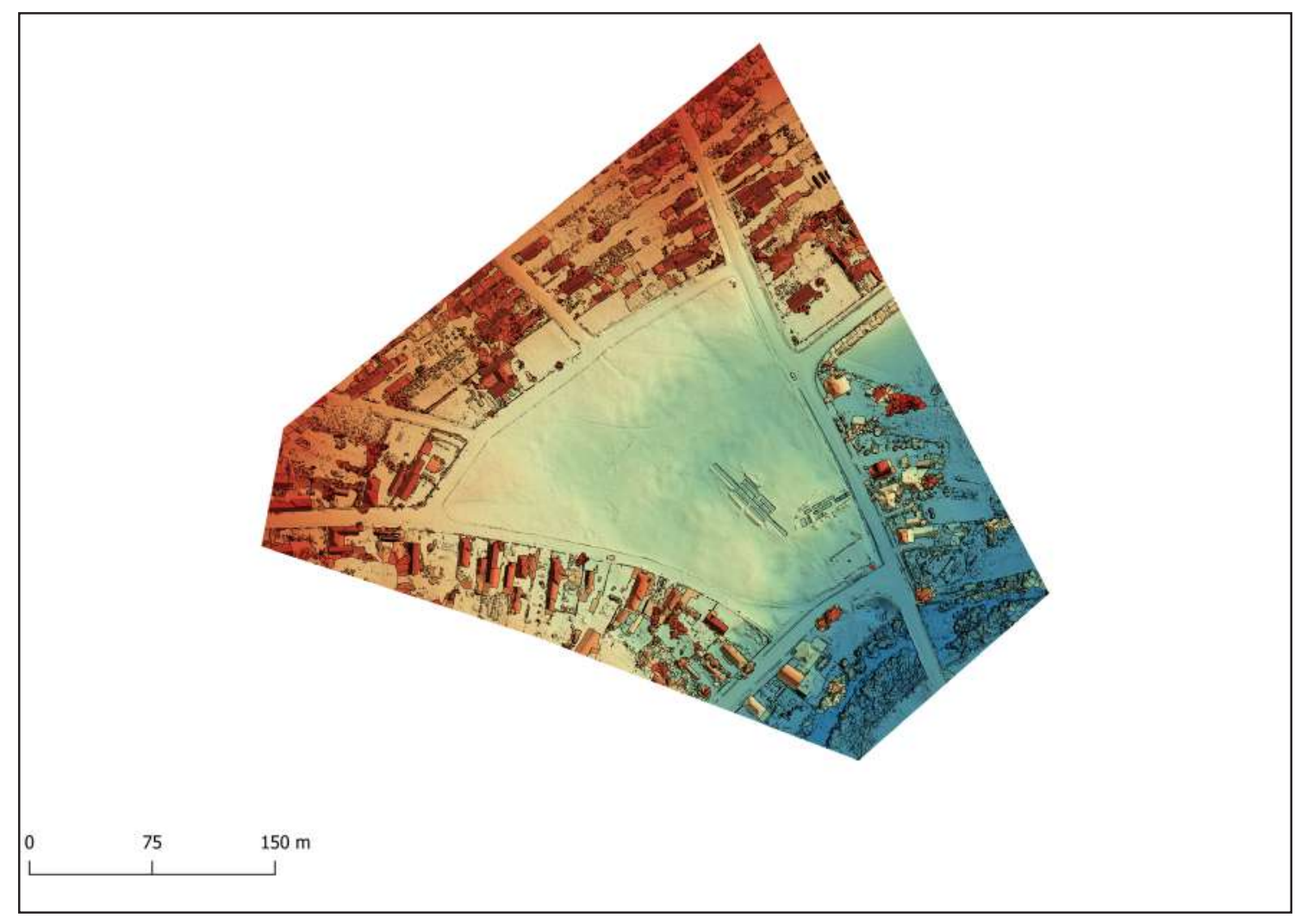

21.5 Reșca (Romula), model digital al terenului.

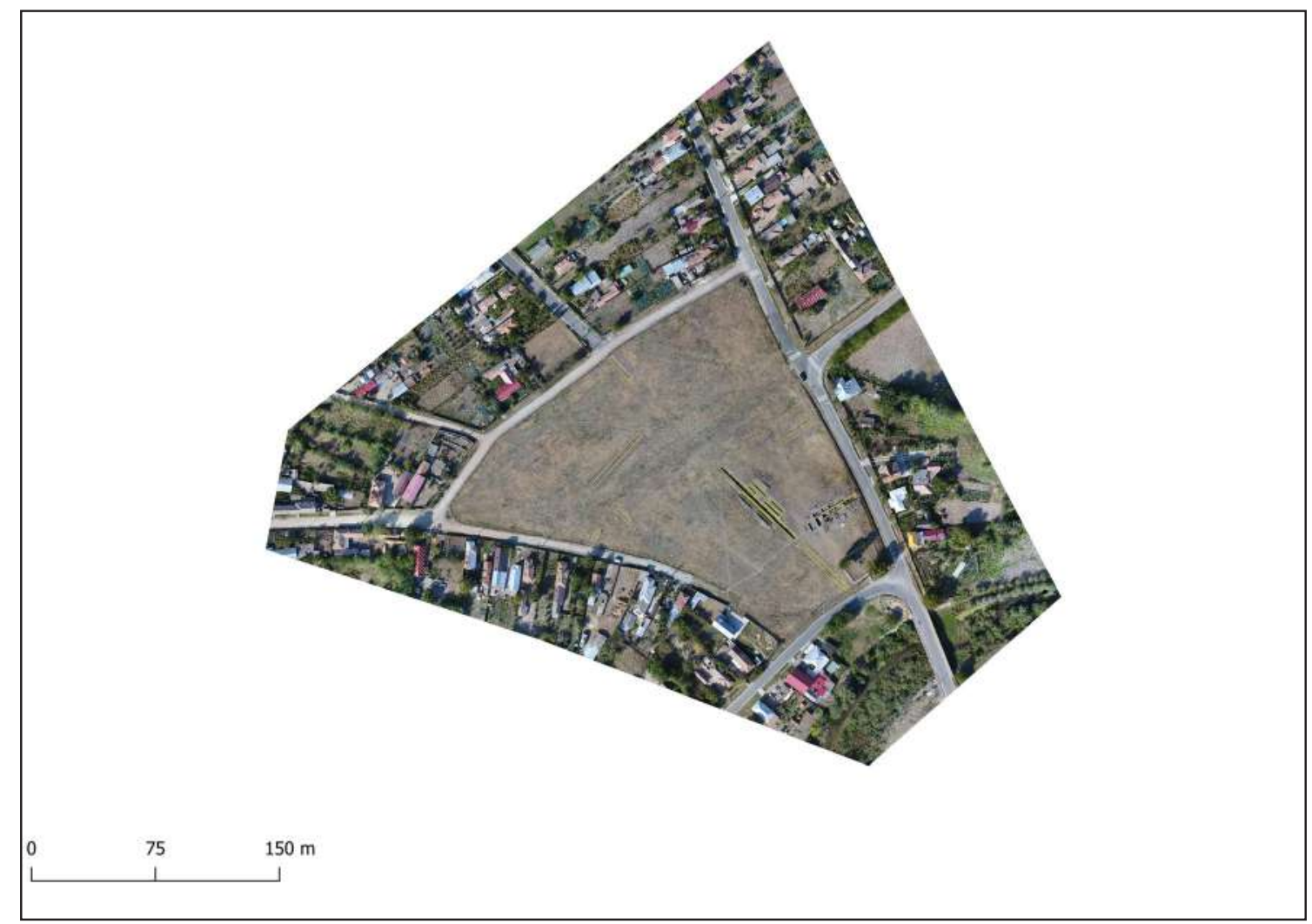

21.6. Reșca (Romula), planul general al săpăturilor arheologice din anii 2011, 2013 și 2015 (după Negru, Schuster 2016, 95 pl. I) suprapunere pe ortofotoplan dronă (2017). 

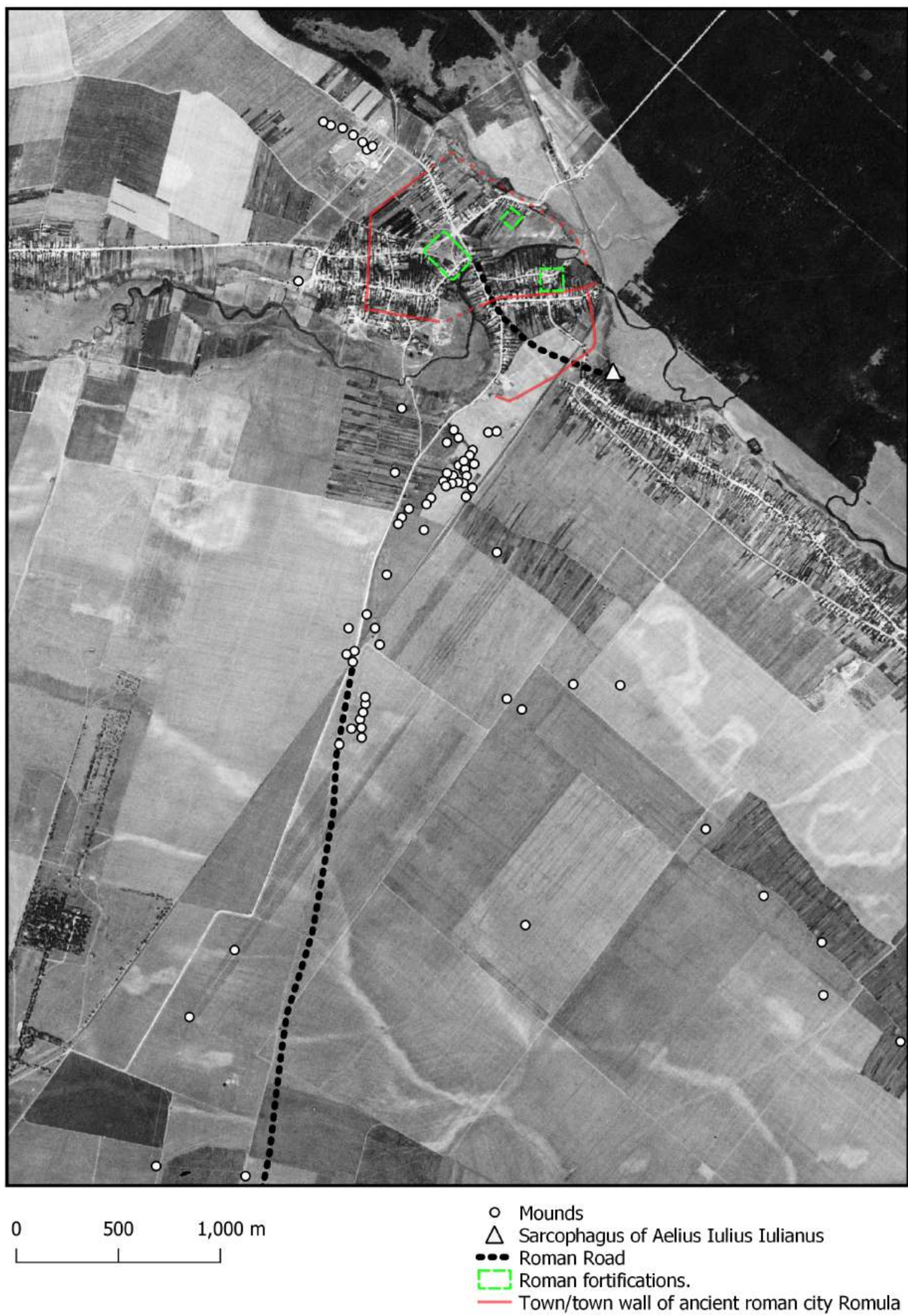

21.7. Reșca (Romula), poziționarea drumurilor romane, a tumulilor, castrelor și a incintei orașului antic Romula, suprapuse pe o poză declasificată satelit Corona 1968 (1104-2155 Aft; Aug 17, 1968 Center for Advanced Spatial Technologies,

University of Arkansas/U.S. Geological Survey). 

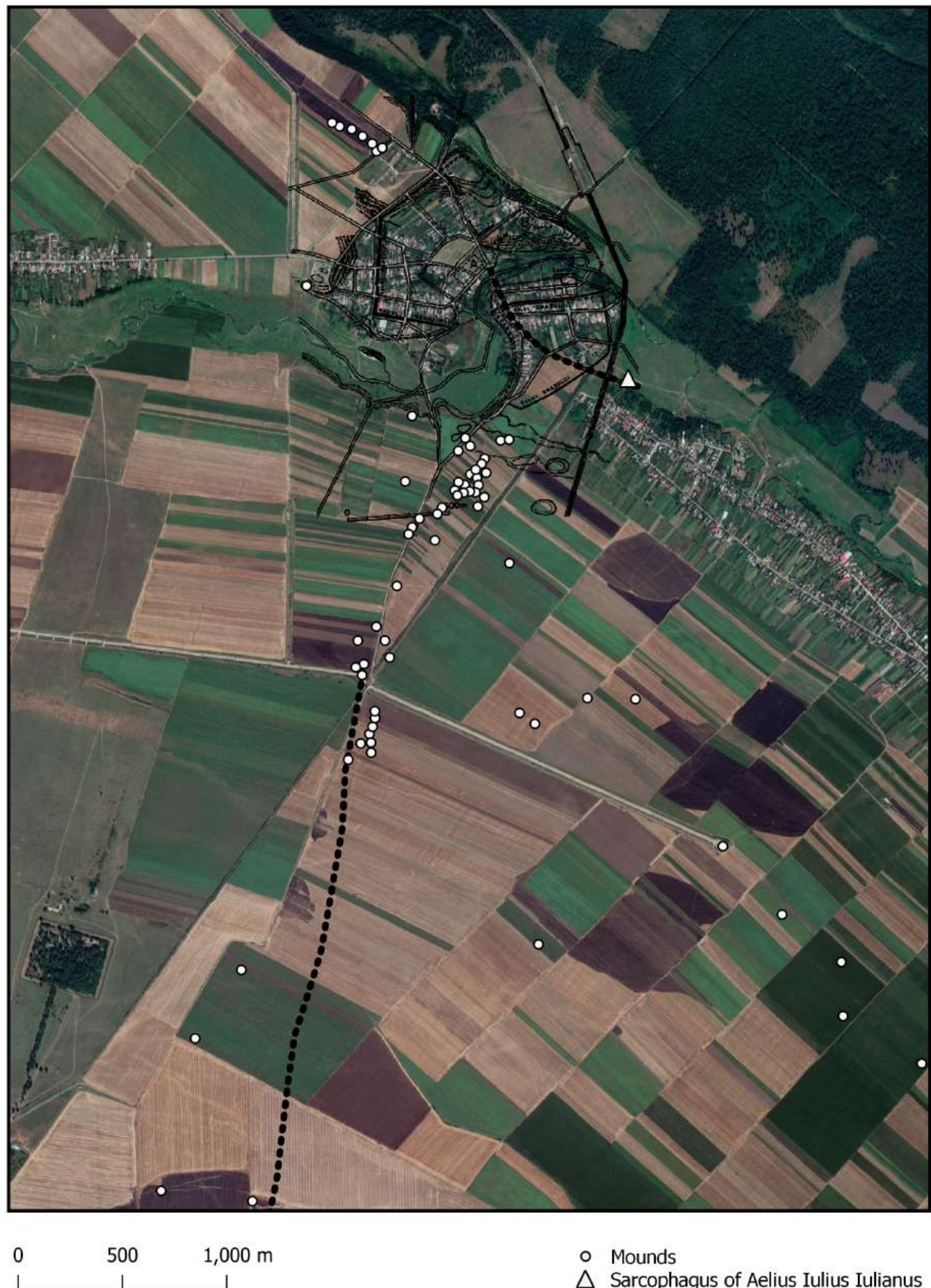

\section{- Mounds \\ $\triangle$ Sarcophagus of Aelius Iulius Iulianus $\bullet$ Roman Road} (Tudor 1978, 179, fig. 2) suprapuse pe ortofotoplan Google Earth (2021). 


\section{Slăveni}

Com. Gostavăţu, jud. Olt (RAN: 127162.01; OT-I-s-B-08531)

Castrul (fig. 22.1 - 22.5) este situat în zona centrală a satului actual, în punctul Cetate, fiind suprapus în cea mai mare parte de clădirile moderne. Cercetările arheologice (D. Tudor, Gh. Popilian, O. Toropu 19601985) au evidențiat trei faze constructive.

În prima fază, castrul avea plan dreptunghiular $(169 \times 190 \mathrm{~m})$, fiind apărat de o palisadă de lemn și poate data din perioada traianică. În interior au fost identificate străzile principale, principia şi şase barăci de lemn. Trupele atestate sunt ala Hispanorum (120 - 126); ala Claudia (Gallorum); cohors I Flavia Commagenorum (IDR II 528); CIB (IDR II 527), probabil cohors I Brittonum/Britannica sau cohors I Bracaraugustanorum. De asemenea sunt atestate ștampile cu numele legiunilor XIII Gemina, V Macedonica şi XI Claudia p. f.

Castrul de piatră avea aceleași dimensiuni și orientare cu fortificaţia anterioară, pe care o suprapune, fiind înconjurat de trei șanțuri. Turnurile de colț sunt trapezoidale, iar turnurile de poartă sunt dreptunghiulare, ușor ieșite în exterior. În interior au fost identificate principia $(37 \times 43 \mathrm{~m})$, două clădiri, din

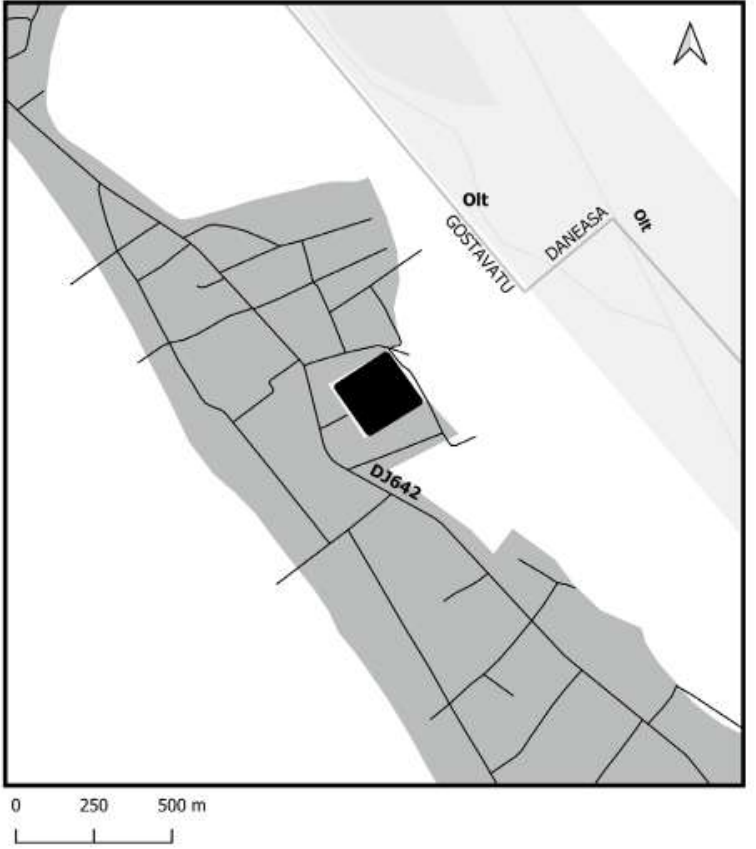

22.1. Slăveni, localizarea sitului și a băilor. care un horreum, în latus sinistrum, respectiv o clădire dreptunghiulară în latus dextrum. În praetentura au fost identificate șase barăci. Castrul de piatră a fost construit în 205 p. Chr. (IDR II 496 sau numai porta praetoria). Trupa aflată în garnizoană a fost ala I Hispanorum, atestată prin inscripții şi material tegular. Ştampile atestă numerus Syrorum (NS) şi numerus singularium (NSING) - ar putea însă ca ambele ştampile să se refere la numerus singularium (prezența acestei unități la Slăveni ar fi problematică, întrucât procuratorul Daciei Inferior a staționat cel mai probabil la Romula-Malva).

A treia fază reprezintă o etapă de reparații din timpul lui Philippus Arabs, atestată la principalele clădiri. Castrul a fost distrus pe la mijlocul sec. III p. Chr. după cum indică descoperirea unui tezaur monetar ascuns probabil în contextul atacurilor din $247 \mathrm{p}$. Chr.

În jurul fortificaţiei s-a dezvoltat o așezare importantă în care au fost identificate termele (fig. 22.3) și un Mithraeum. Rezultatele cercetărilor arheologice au fost reunite într-un volum în urmă cu un deceniu.

Bibliografie: Tocilescu 1900, 120-121; Christescu 1937, 199-200; TIR L 35, 67-68; Tudor, D. 1940. Castra Daciae Inferioris: II. Castrul şi aşezarea romană de la Slăveni-Romanaţi. Il castro romano di Slăveni, Romanaţi (Romania). Buletinul Comisiunii Monumentelor Istorice 33: 34-38; Tudor 1968, 357-358; Tudor, 1970. Distrugerea castrului roman de a Slăveni. Historica 1: 67-83; Tudor, D. 1973. Recentele săpături de pe valea Oltului Inferior. Apulum 11: 115-127; Tudor, D. 1974. Basilica castrensis de la Slăveni pe Olt. Drobeta 1: 47-53; Popilian, Gh. 1974. Aspecte ale circulației monetare în castrul și așezarea romană de la Slăveni. Oltenia. Studii și comunicări 1: 75-82; Tudor, D. 1975. Trupele din castrul roman de la Slăveni. Studii şi materiale de muzeografie şi istorie militară 7-8: 13-21; Tudor 1978, 301-307; Toropu, O. 1978. Un nou tezaur monetar descoperit la Slăveni. Drobeta 3: 62-68; Vlădescu 1983, 82-85, nr. 7; Vlădescu 1986, 30-34; Bogdan-Cătăniciu 1997, 62-64; Gudea 1997, 83-85, nr. 69; Gudea 2005, 492-493, nr. VII.B.2; Dudău 2006, 63, nr. 5; 72-73, nr. 21-22; 134-135; Marcu 2009, 231-243, nr. 71; Tudor, D., Popilian, Gh., Gudea, N. și Bondoc, D. 2011. Castrul roman de la Slăveni. Incercare de monografie arheologică, Cluj-Napoca: Mega. 


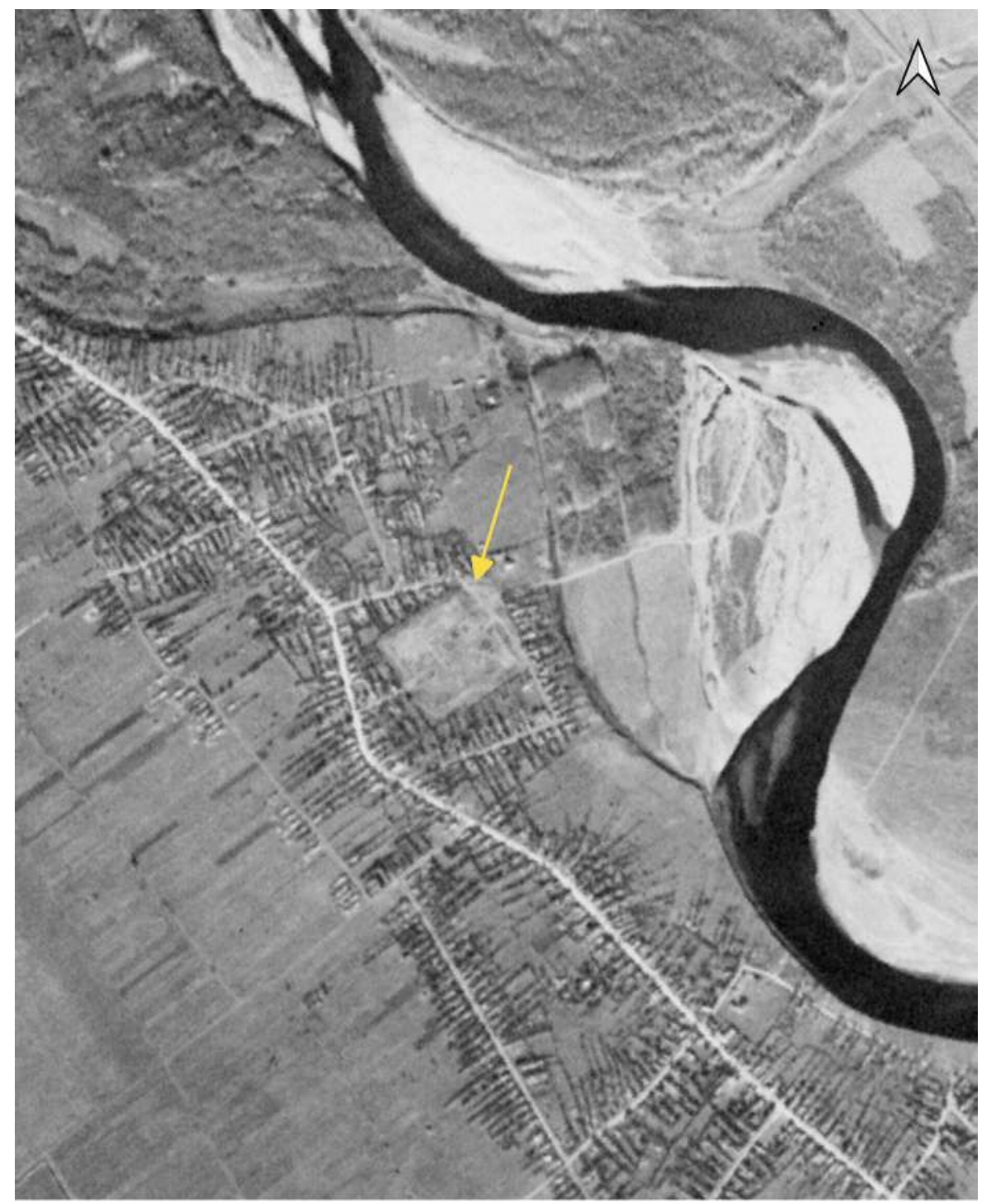

22.2. Slăveni, localizarea sitului, poză declasificată satelit Corona 1965 (10262088 Aft; Nov 03, 1965 Center for Advanced Spatial Technologies, University of Arkansas/U.S. Geological Survey). 

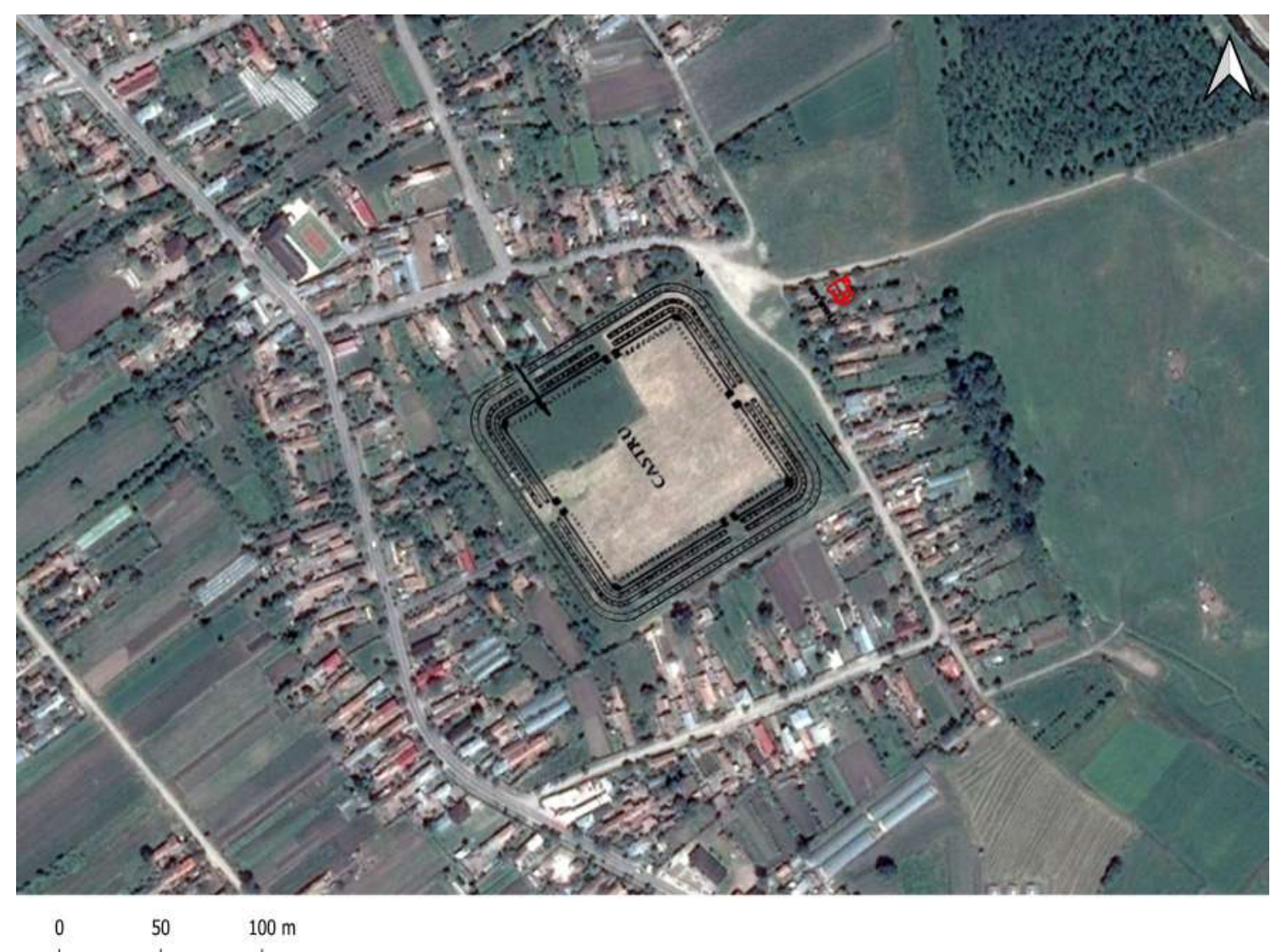

22.4. Slăveni, planul castrului și al thermelor (Tudor et al. 2011, 143, fig. 88) suprapus pe ortofotoplan Google Earth.

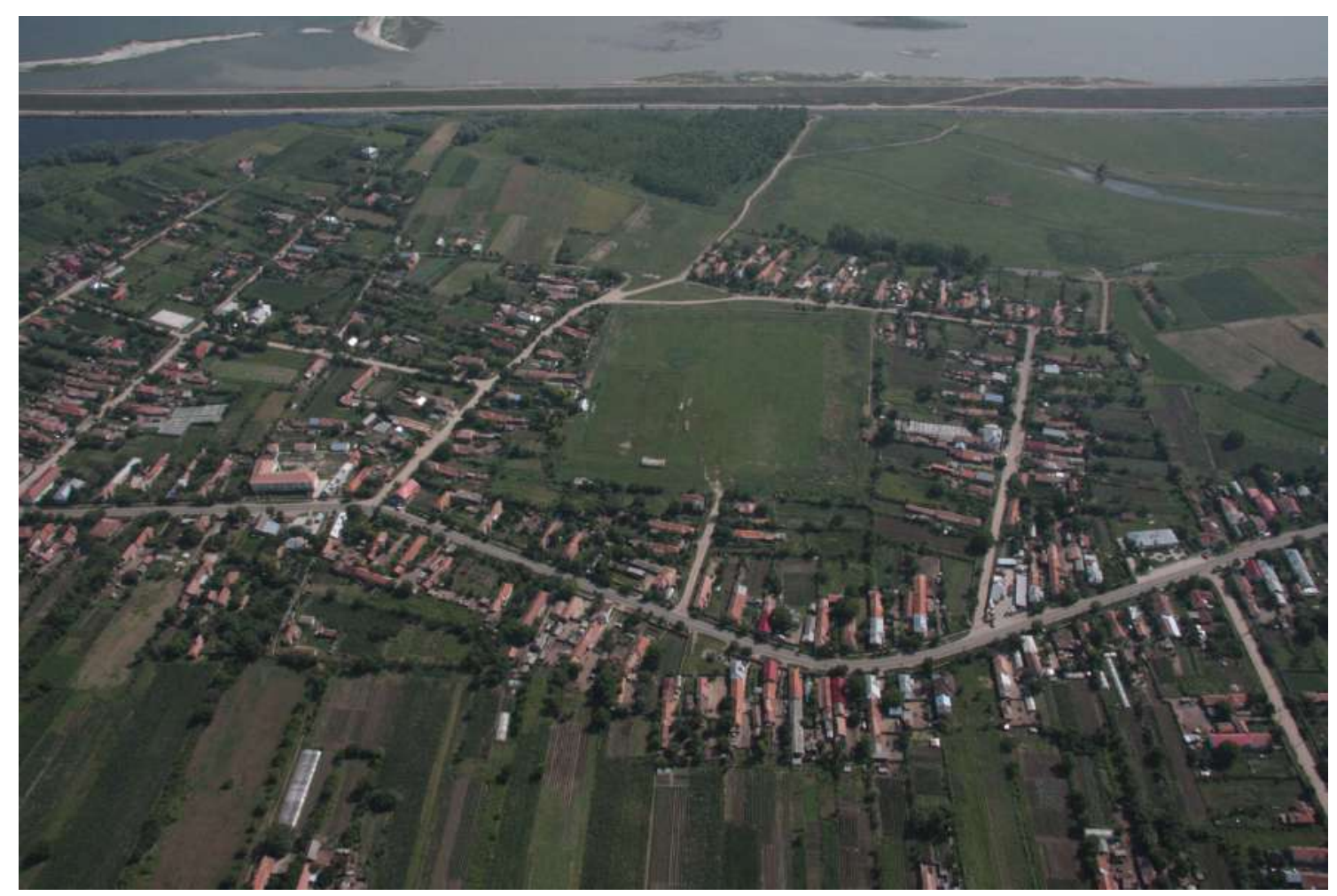

22.5. Slăveni, fotografie oblică aeriană, vedere dinspre vest (iulie 2010). 


\section{Tia Mare}

Com. Tia Mare,jud. Olt(RAN: 129479.01)

Un posibil castru auxiliar (fig. 23.1 - 23.4) a fost semnalat la Est de satul actual, pe malul drept al Oltului. Aici a fost presupusă existenţa unei mici fortificații de piatră $(30 \times 30 \mathrm{~m})$. De asemenea, în punctul „Rovină”, au fost semnalate elemente de zidărie, ţigle, cărămizi, gropi cu zgură, terra sigillata și ceramică provincială.

În anul 1977, C. M. Vlădescu și N. Moghior au făcut sondaje în trei puncte în care putea fi identificat un castru. Rezultatele acestora au semnalat artefacte databile în perioada romană, dar nu și structuri constructive relevante.

Bibliografie: Vlădescu, C.M., Maghiar, N. 1978. Notă asupra sondajelor la Tia Mare, jud. Olt. Studii şi materiale de muzeografie şi istorie militară 11: 167-171; Tudor 1978, 301; Bogdan-Cătăniciu 1997, 62; Gudea 1997, 83, nr. 68; Gudea 2005, 122, nr. 7; Marcu 2009, 243, nr. 73.

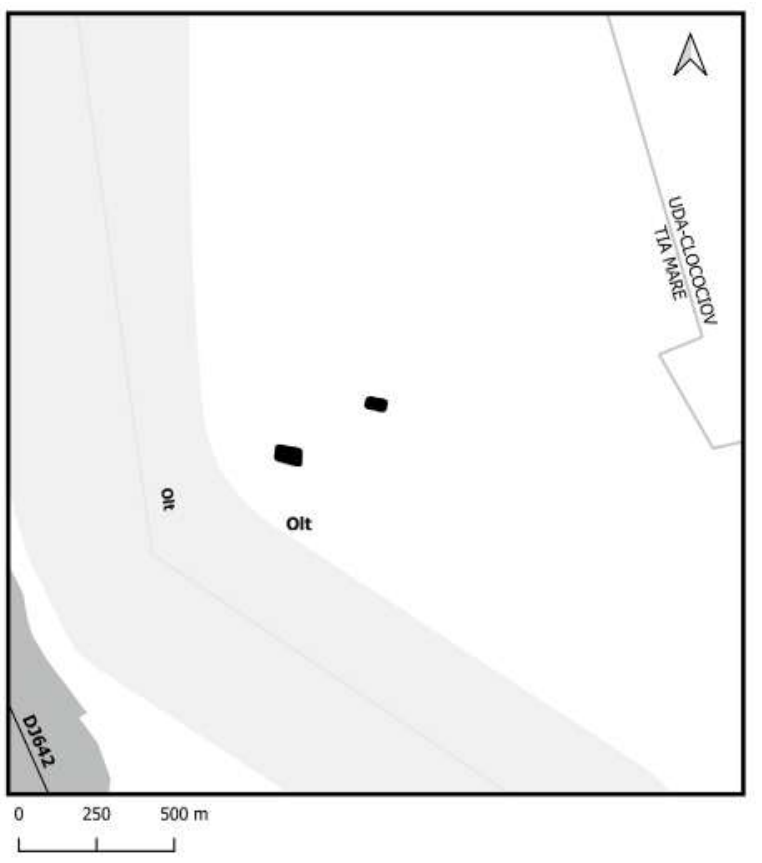

223.1. Tia Mare, localizarea sitului.

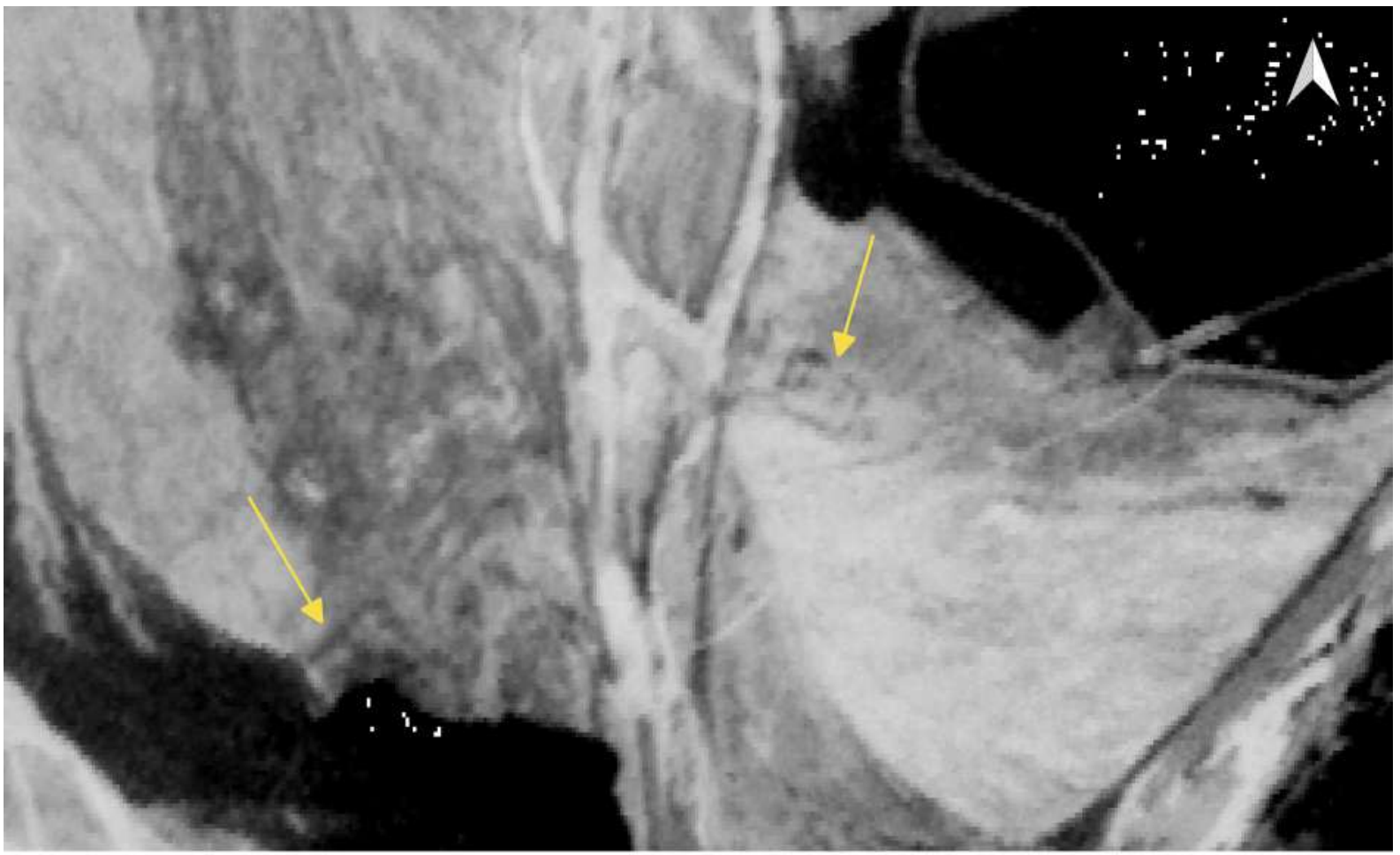

0 $75 \mathrm{~m}$

23.2. Tia Mare, localizarea sitului, poză declasificată satelit Corona 1968 (1103-1058 Fore; May 05, 1968 Center for Advanced Spatial Technologies, University of Arkansas/U.S. Geological Survey). 


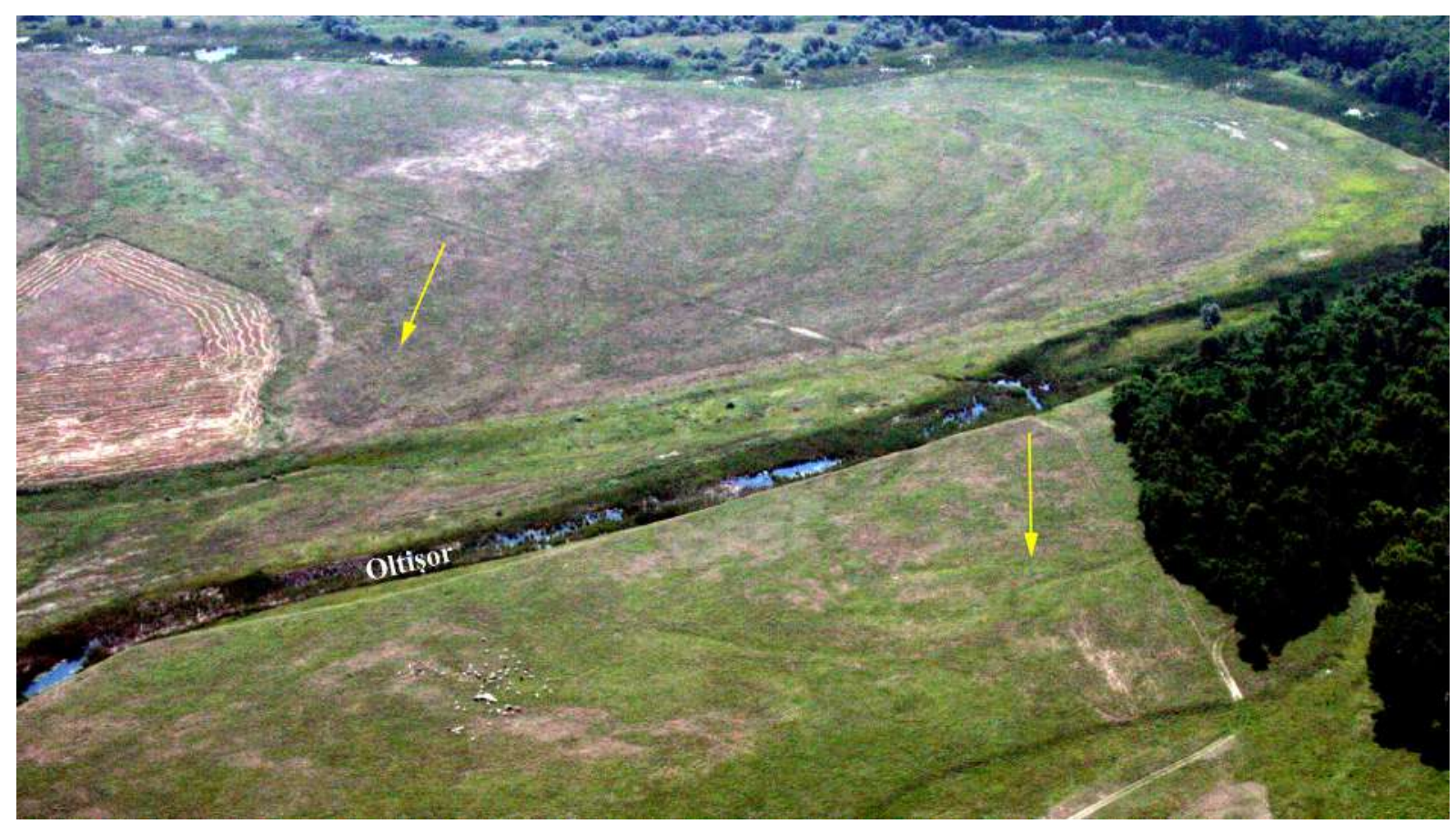

23.3. Tia Mare, fotografie oblică aeriană, vedere dinspre Nord-Vest (iulie 2010).

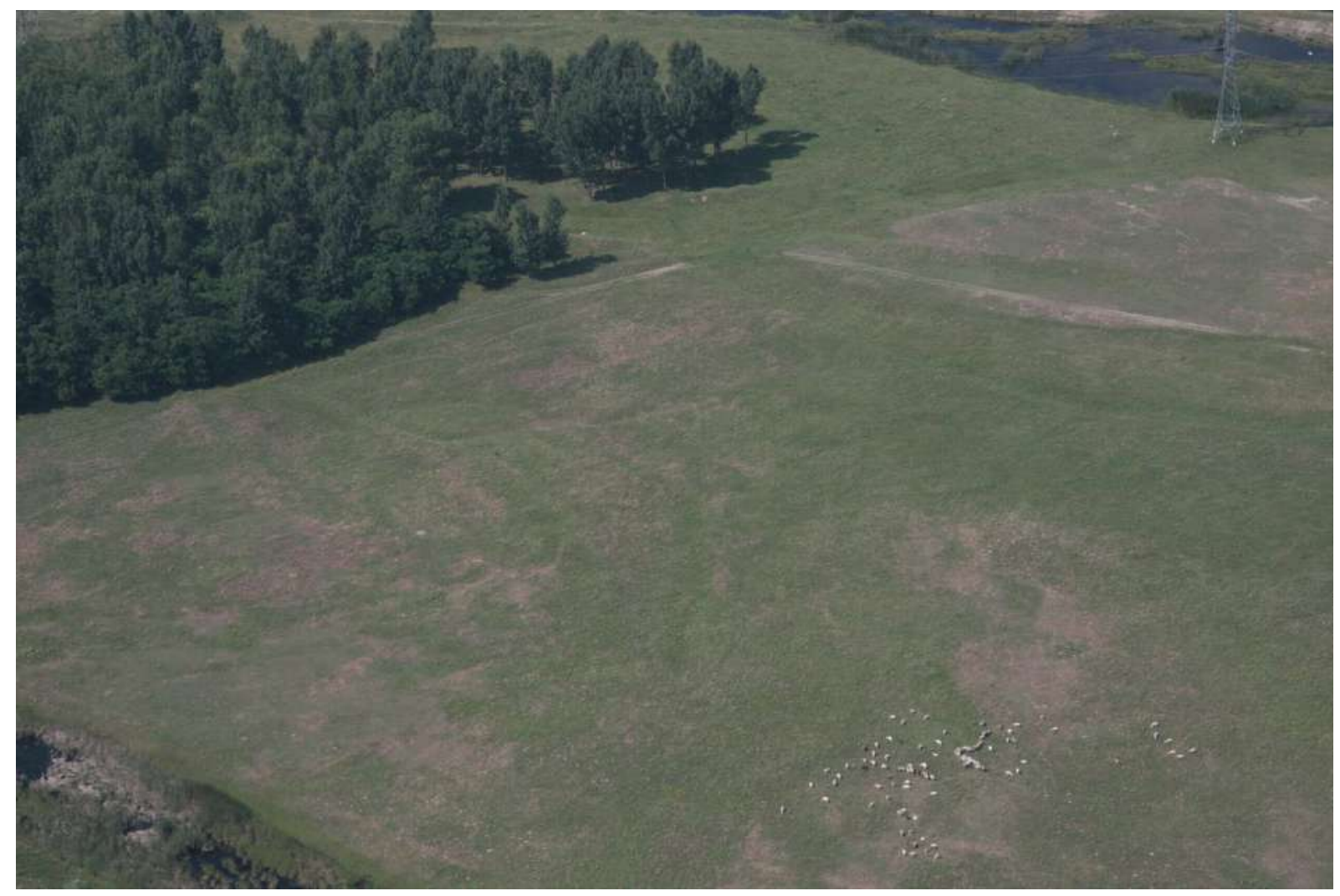

23.4. Tia Mare, fotografie oblică aeriană, vedere dinspre Nord-Est (iulie 2010). 


\section{Islaz}

Com. Islaz, jud. Teleorman. (RAN: 151745.01; TR-I-s-B-14206)

În vecinătatea satului Izlaz (fig. 24.1 - 24.6), au fost semnalate trei castre, două amplasate în proximitatea Dunării și unul pe malul Oltului. Unul este complet distrus de Dunăre.

Dintre acestea, unul cu incinta din piatră a fost menționat în punctul „Cetatea Racoviţ̧a”, situat la Nord-Est de localitatea actuală, într-o zonă mlăștinoasă a pârâului Racoviţa, care se varsă în Olt. Denumirea Islaz-Racovița vine de la pârâul aflat în apropiere (fig. 24.1.A, 24.2, 24.3A, 24.4);

Se păstra doar colțul de Nord-Vest $(75 \times 105$ m), prevăzut cu val și șanț de apărare. Au fost identificate cărămizi romane și fragmente ceramice. Ar putea data din epoca traianică, dar lipsesc elemente certe. Nu mai sunt urme vizibile la suprafață, fortificația fiind distrusă aproape integral de eroziune și de cimitirul satului (fig. 24.2.a - roșu).

O fortificație a fost semnalată în punctul „Cetatea Verdea”, situat la Sud-Vest de Izlaz, pe o insulă a Dunării, în apropierea vărsării Oltului în Dunăre. Denumirea Vedea (sau Verdea) vine de la fosta insulă Verdea, formată de cursul Dunării (păstrată pe planurile directoare de tragere). Fortificația era situată la aproximativ un km Nord de această insulă (fig. 24.2.b. - galben; fig. 24.5). A fost puternic afectată de cursul râului, fiind în mare parte distrusă. În anul 1876, au fost făcute anumite observații de A. T. Laurian, când erau vizibile trei şanţuri și trei valuri, care conturau un castru cu dimensiunile de $120 \times 340 \mathrm{~m}$. La acea dată au fost menționate descoperirile unor sarcofage de piatră și ale unor monede datate în timpul lui Septimius Severus, precum și un sestertius datat în perioada lui Traian.

În anul 1977, au fost efectuate câteva sondaje în care au fost descoperite structuri care se pot atribui aşezării civile romane. Ioana Bogdan-Cătăniciu presupunea că aceste castru a fost construit în perioada lui Hadrianus.

A treia fortificație semnalată de Laurian și Bolliac $(95 \times 122 \mathrm{~m})$, punct din care a fost extrasă multă cărămidă romană, a fost complet distrusă. Este posibil să fie vorba de punctul Islaz-Ostrovu (fig. 24.2.c. - verde). Pe planurile directoare de tragere figurează sub denumirea Ostrovul Verde /Ostrovul Calnovăț.

Bibliografie: Tudor 1978, 279; Cătăniciu 1981, 30; Vlădescu 1983, 81, nr. 6; Vlădescu 1986, 29-30; Gudea 1997, 82, nr. 67; Gudea 2005, 492, nr. VII. B. 1; Dudău 2006, 116; Marcu 2009, 212, nr. 56.

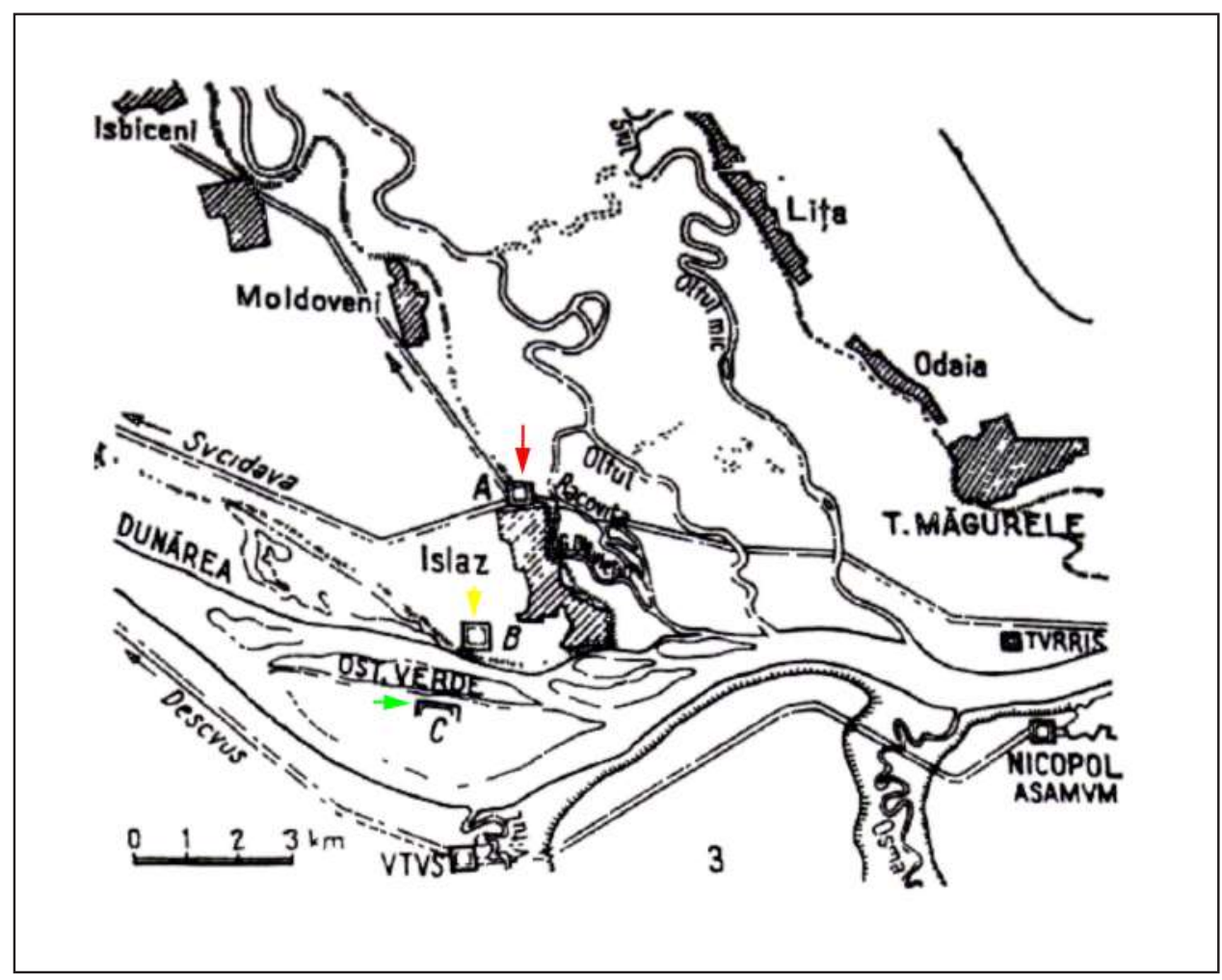

24.1. Islaz, castrele de la Islaz (Tudor 1978, 266, fig. 68/3). 

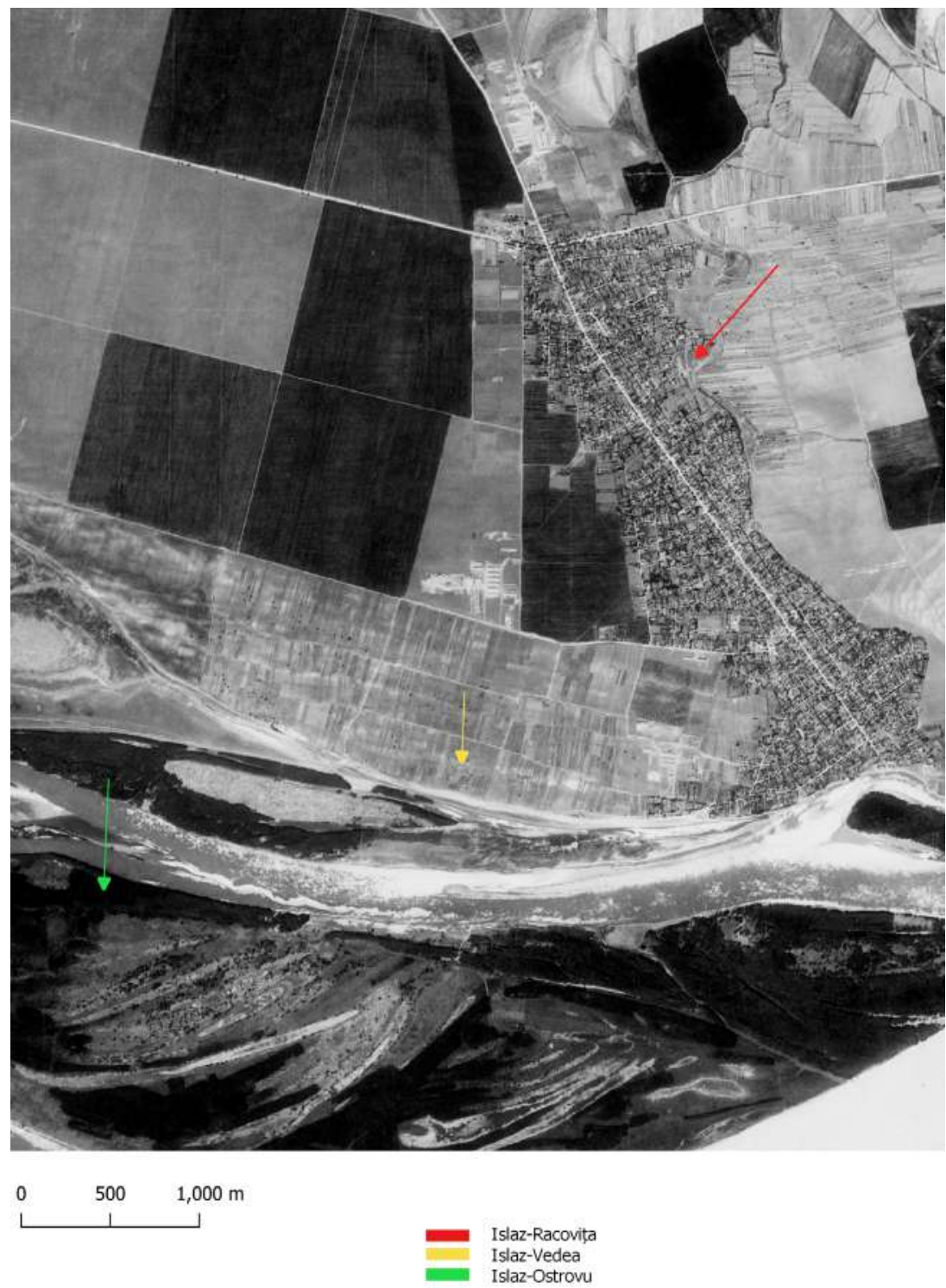

24.2. Islaz, localizarea fortificațiilor, poză declasificată satelit Corona 1968 (1103-1058 Fore; May 05, 1968 Center for Advanced Spatial Technologies, University of Arkansas/U.S. Geological Survey).

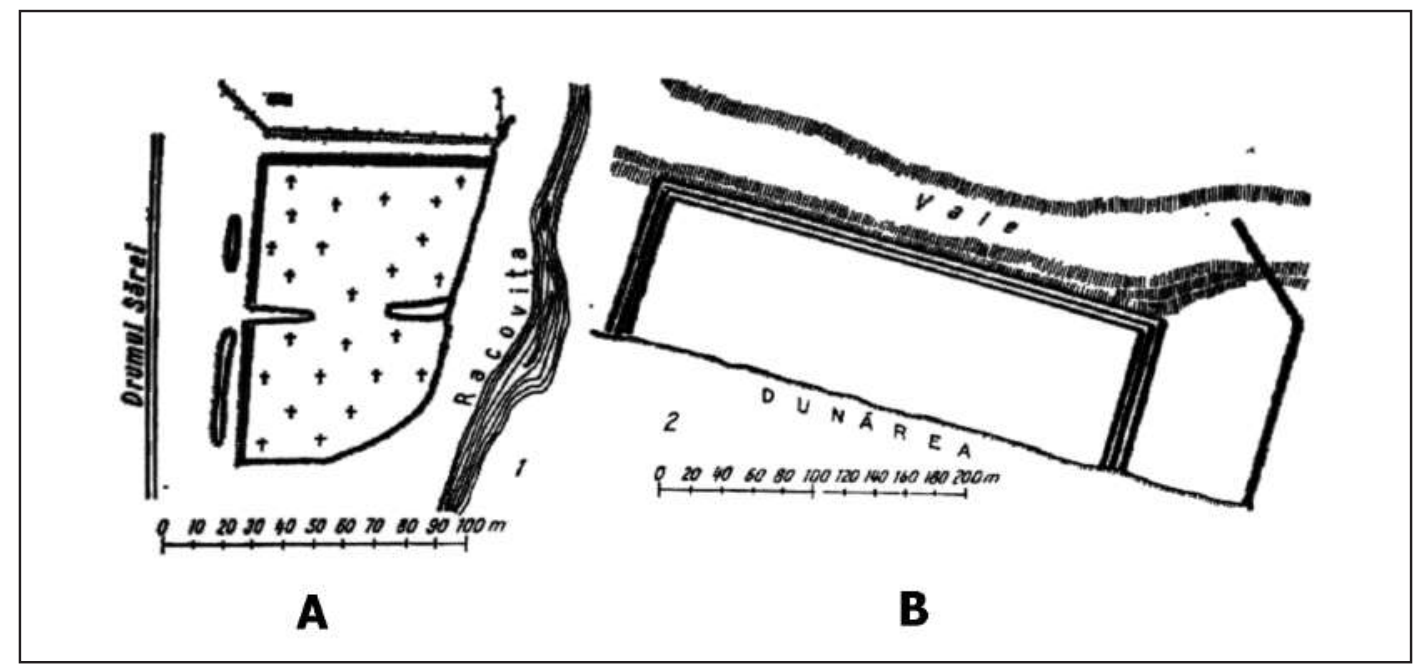

24.3. Islaz, castrele de la Islaz Racovița (A) și Islaz Vedea (B) (Tudor 1978, 278, fig. 75/1-2). 


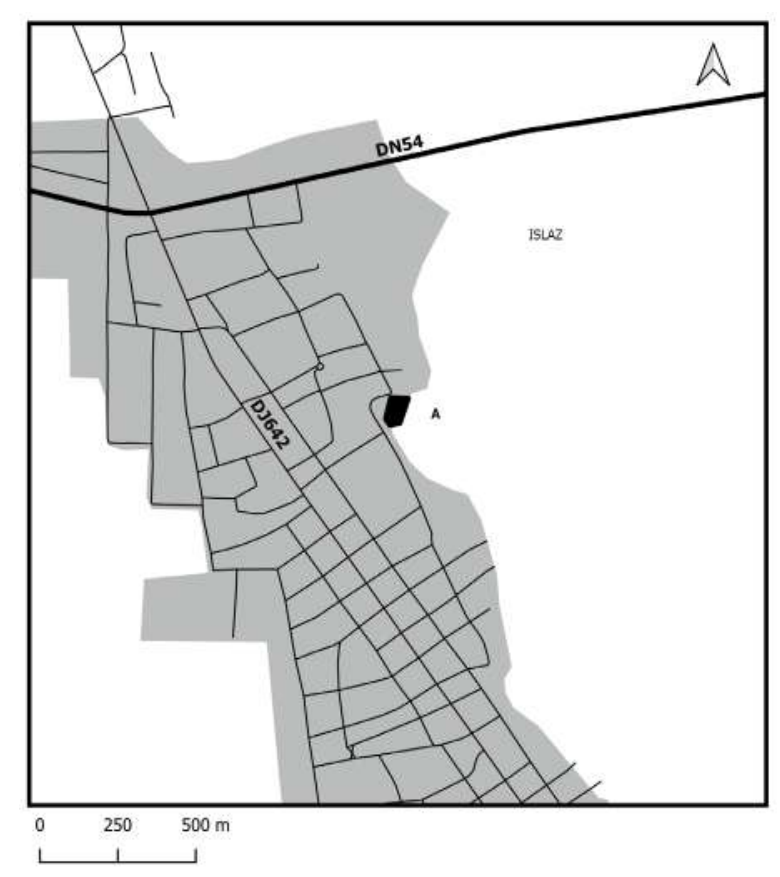

24.4. Islaz, Islaz-Racovița, localizarea sitului (A).

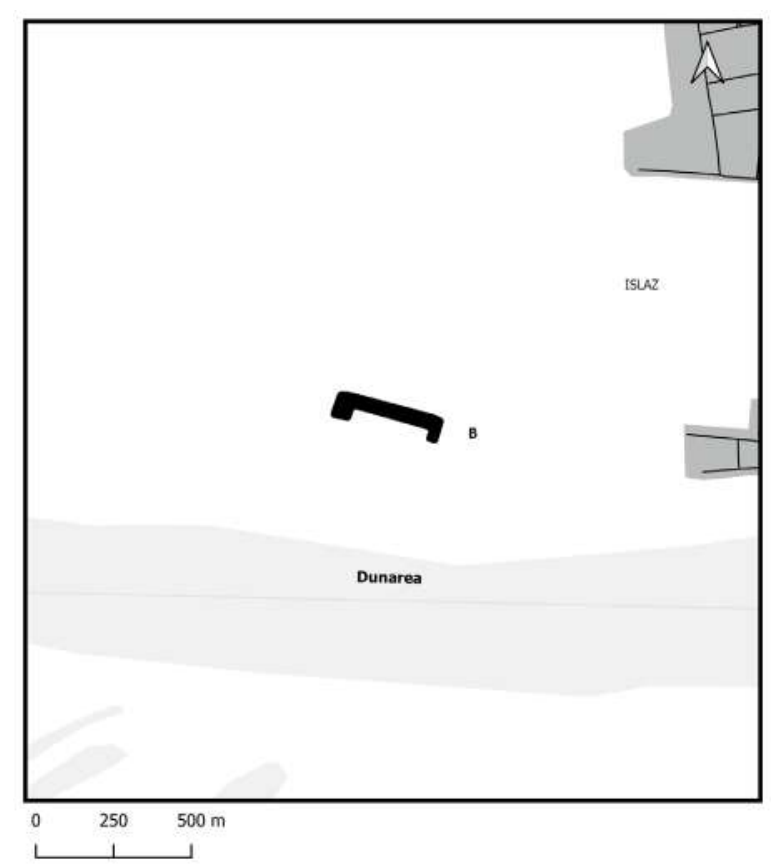

24.5. Islaz, Islaz-Vedea, localizarea sitului (B).

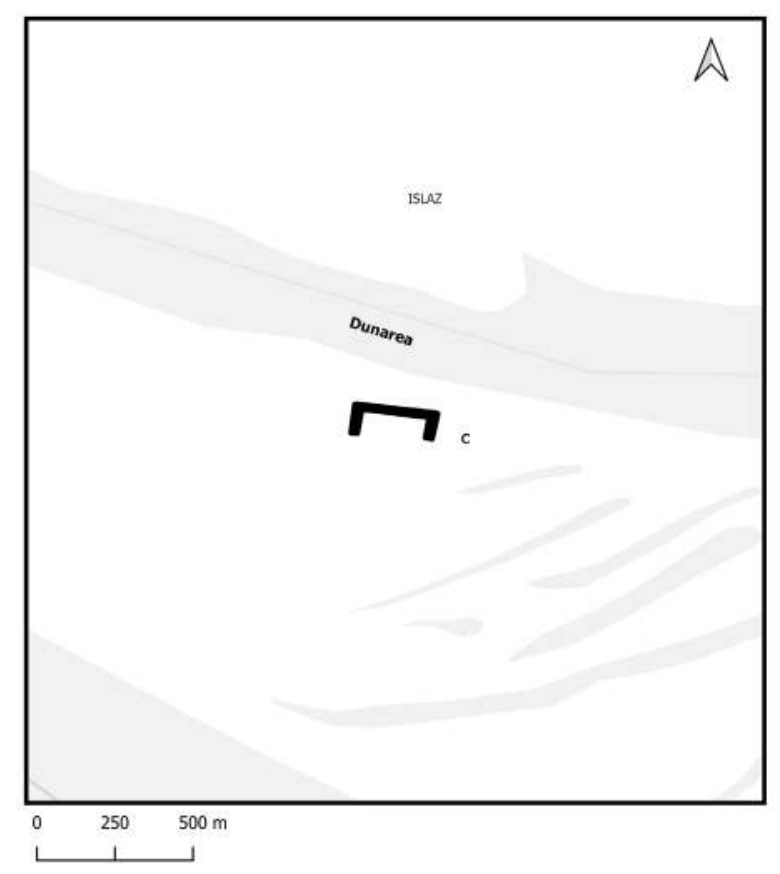

24.6. Islaz, Islaz-Ostrovu, localizarea sitului (C). 


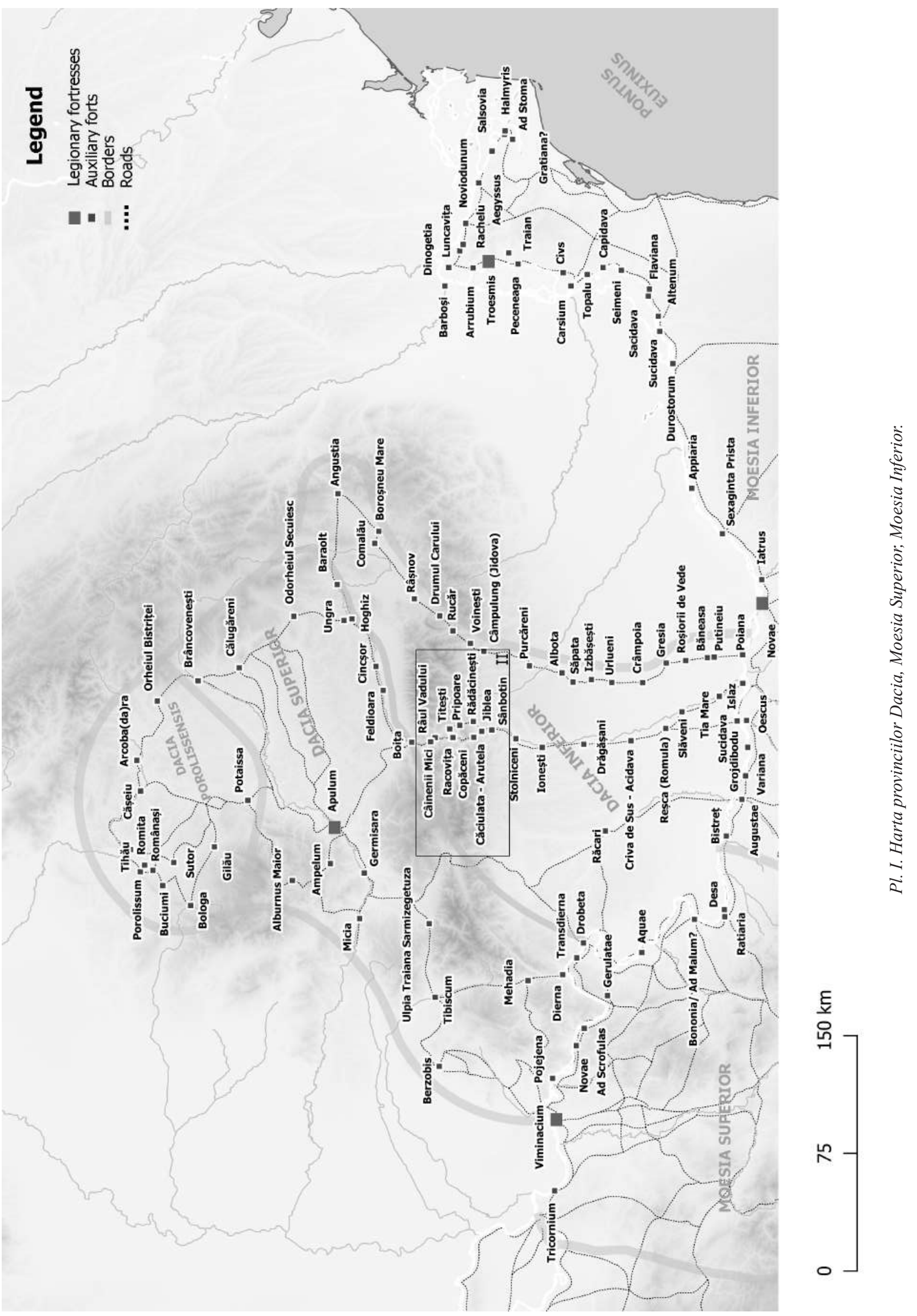




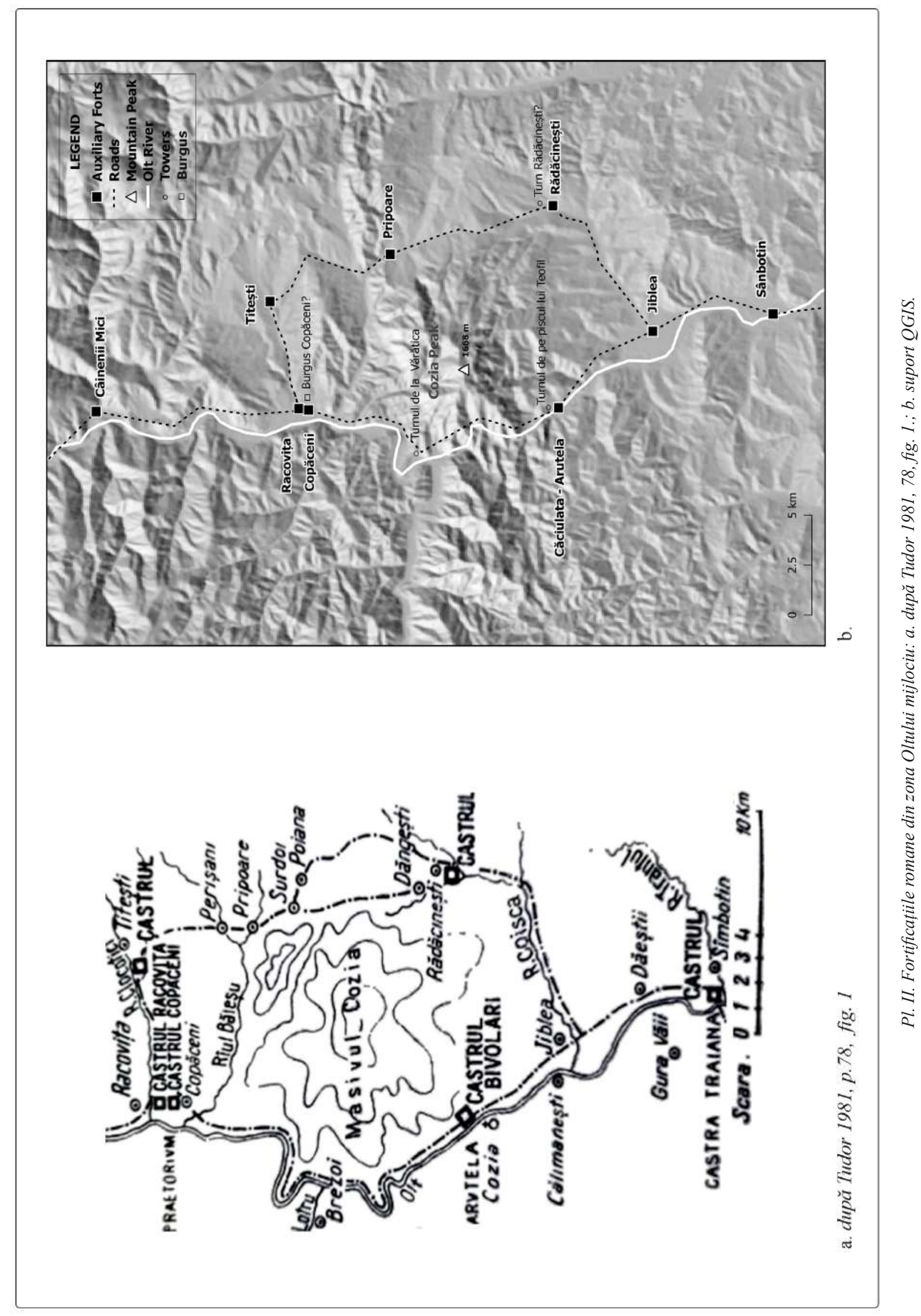




\section{BIBLIOGRAFIE}

CIL

IDR II

Corpus Inscriptionum Latinarum, Berlin.

Inscriptiile Daciei Romane II. Oltenia şi Muntenia (Gr. Florescu, C.C. Petolescu), Bucureşti: Editura Academiei, 1977.

IDR III 4

Inscriptiile Daciei romane III. Dacia Superior 4 (zona răsăriteană), (I.I. Russu), Bucureşti: Editura Academiei 1988.

ILD

C. C. Petolescu, Inscripțiile latine din Dacia, București: Editura Academiei 2005.

ILS

Dessau, H. Inscriptiones Latinae Selectae. Berlin 1892-1916, 3 vol.

TIR L 35

Russu, I. I., Gostar, N., Ivanov, T., Popescu, Em., Protase, D., Tudor, D., Tabula Imperii Romani. Romula - Durostorum - Tomis. L 35, Bucarest: Editura Academiei Române, 1969.

Bichir, Gh., Sion A. şi Bardaşu, P. 1992. Aşezarea de la Stolniceni, Buridava, jud. Vâlcea. Materiale şi cercetări arheologice. A XVII-a Sesiune anuală de rapoarte. Ploieşti 1983. Bucureşti: Editura Academiei Române: 255-268.

Bogdan-Cătăniciu, Ioana 1981: Evolution of the System of Defence Works in Roman Dacia. BAR IS 116, Oxford, $121 \mathrm{p}$.

Bogdan-Cătăniciu, Ioana 1997: Muntenia în sistemul defensiv al Imperiului Roman. Wallachia in the Defensive System of the Roman Empire $1^{1^{s t}-3^{\text {th }}}$ centuries A.D., Alexandria, $195 \mathrm{p}$.

Christescu, V. 1937. Istoria militară a Daciei Romane, Bucureşti: Fundatia Regelui Carol I.

Conea, I. Țara Loviștei (Studiu de geografie istorică), Buletinul Societății Regale Române de Geografie, Tomul LIII, Monitorul Oficial și Imprimeria Naţională București.

Dudău, O. 2006. Circulația monetară în castrele de trupe auxiliare din provincia Dacia, Timişoara: Graphite.

Gridan, S., Urdea, P. și Hegyi, Al. 2017. Castrul de la Ungra, jud. Braşov. Cercetări Multidisciplinare, în: ArheoVest, Nr. V, în: S. Forțiu ed. In Honorem Doina Benea, Interdisciplinaritate în Arheologie și Istorie, Timişoara, 25 noiembrie 2017 Vol. 2: Metode Interdisciplinare și Istorie: 851-883. Szeged: JATEPress Kiadó.

Gudea, N. 1997. Der dakische Limes. Materialien zu seiner Geschichte. Jahrbuch des Römisch-Germanischen Zentralmuseum Mainz 44, 1: 1-113.

Gudea, N. 2005. Der untermoesische Donaulimes und die Verteidigung der moesischen Nord- und Westküste des Schwarzen Meeres: Limes et litus Moesiae Inferioris (86-275 n. Chr.). Jahrbuch des Römisch-Germanischen Zentralmuseum Mainz 52, 2: 319-566.

Horedt, K., Ferenczi, Şt., Liu, N., Mirea, V. și Rusu, M. Pătrunderea și așezarea slavilor în Transilvania. Studii și Cercetări de Istorie Veche 1, 1, 1950, 123-130.

Isac D. şi Isac A. 1994. Noi date arheologice despre castrul roman de la Cincşor (jud. Braşov), Ephmeris Napocensis 4: 103-112.

Marcu, F. 2009. Organizarea internă a castrelor din Dacia, Cluj-Napoca: Mega,

Petolescu, C. C. 2002. Auxilia Daciae. Contribuţie la istoria militară a Daciei romane, București: Ars Docendi.

Poenaru-Bordea, Gh., Vlădescu, C. M. 1974. Les fortifications romaines sur le Limes Alutanus dans la zone du massif de Cozia, in: D. M. Pippidi (ed.), Actes du IX-e Congrès international d'études sur les frontières romaines, Mamaia, 6 - 13 septembrie 1972, București: Editura Academiei Române; Köln; Wien: Böhlau Verlag: 247-261.

Piso, I. 2013. Fasti provinciae Daciae II. Die ritterlichen Amtsträger, Bonn: Dr. Rudolf Habelt (Antiquitas. Reihe 1. Abhandlungen zur Alten Geschichte 60).

Tocilescu, Gr. G. 1900. Fouilles et recherches archéologiques en Roumanie. Communications faites à l'Académie des Inscriptions et Belles-Lettres de Paris, 1892-1899, Bucarest.

Tudor, D. 1968. Oltenia Romanăă , Bucureşti: Editura Științifică.

Tudor, D. 1978. Oltenia Romană4 , București: Editura Academiei Române.

Tudor, D. 1981. Comandamentele militare de la Praetorium în Dacia. Studii și Cercetări de Istorie Veche 32, 1, 76-88. 
Tudor, D., Nubar, H. și Purcărescu, P. 1970. Săpăturile arheologice de la Castra Traiana. Materiale și Cercetări Arheologice 9: 245-250.

Tudor, D., Popilian, Gh., Gudea, N. și Bondoc, D. Castrul roman de la Slăveni. Incercare de monografie arheologică, Cluj-Napoca: Mega, 2011.

Țentea, O. şi Popa, Al. 2017. Castrul şi băile romane de la Hoghiz - Rezultatele recente ale prospecțiunilor geofizice, Cercetări Arheologice 24: 137-143.

Vlădescu, C.M. 1982. Centrele militare romane din sectorul de nord al limesului alutan. Buridava 4: 55-65.

Vlădescu, C. M. 1983. Armata romană în Dacia Inferior, Bucureşti: Editura Militară.

Vlădescu, C.M. 1985. Tehnica de construcţie a castrelor care constituiau apărarea masivului Cozia. Studii vâlcene 7: $33-41$.

Vlădescu, C. M. 1986. Fortificaţiile romane din Dacia Inferior, Craiova: Scrisul românesc.

Vlădescu, C.M., Poenaru-Bordea, Gh. 1972. Un segment din limes Alutanus. Fortificaţiile romane din jurul masivului Cozia. Buletinul Monumentelor Istorice 41, 3: 27-32.

Vlădescu, C.M., Poenaru-Bordea, Gh. 1974. Castrele hadrianee din valea carpatică a Oltului. Oltenia 1: 47-59.

Vlădescu, C.M și Poenaru-Bordea, Gh. 1974a: Les fortifications romaines sur le limes Alutanus dans la zone du massif de Cozia. in: D. M. Pippidi (ed.), Actes du IX-e Congrès international d'études sur les frontières romaines, Mamaia, 6 - 13 septembrie 1972, București: Editura Academiei Republicii Socialiste România; Köln; Wien: Böhlau Verlag: 247-258.

\section{ILLUSTRATIONS}

\section{Hoghiz}

1.1. Location of the Hoghiz and Ungra forts on shooting master plan.

1.2. Hoghiz, fort and baths location.

1.3. Hoghiz, fort plan (Horedt et al. 1950, 125).

1.4. Hoghiz, plan of geophysical surveys carried out in the fort and partially in the civil settlement (Țentea, Popa 2018, 140, fig. 5).

1.5. Hoghiz, oblique drone photograph, south-west view (November 2016).

1.6. Hoghiz, drone orthophotoplan.

1.7. Hoghiz, hillshade model.

1.8. Hoghiz, digital terrain model.

1.9. Hoghiz, plan of geophysical surveys carried out in the fortification and partially in the civil settlement overlaid, on the digital terrain model.

1.10. Hoghiz, the reconstructed plan overlaid on the digital terrain model.

1.11. Hoghiz, the reconstructed plan of fortification and civil settlement.

\section{Ungra}

2.1. Ungra, fort location.

2.2. Ungra, fort location, declassified 1968 Corona satellite photo (U.S. Geological Survey, 2008).

2.3. Ungra, plan of geophysical surveys carried out in the fort (Gridan et al. 2017, 856, fig. 3).

2.4. Ungra, fort's plan (Gridan, S., Urdea, P. și Hegyi, Al. 2017, 861, fig. 9).

\section{Cincşor}

3.1. Cincşor, fort location.

3.2. Cincşor, fort location on shooting master plan.

3.3. Cincşor, fort location (Isac, Isac 1994, 103, fig. 1).

3.4. Cincşor, fort plan (Isac, Isac 1994, 105, fig. 2). 
3.5. Cincşor, oblique drone photograph, south-east view (November 2016).

3.6. Cincşor, drone orthophotoplan.

3.7. Cincşor, hillshade model.

3.8. Cincşor, the reconstructed plan (Isac, Isac 1994, 105, fig. 2) overlaid on the digital terrain model.

\section{Feldioara}

4.1. Feldioara, fort location.

4.2. Feldioara, fort location on shooting master plan.

4.3. Feldioara, fort plan (Gudea 1997, 69, nr. 45).

4.4. Feldioara, drone orthophotoplan.

4.5. Feldioara, fort plan (Gudea 1997, 69, nr. 45) overlaid on the digital terrain model.

\section{Boița (Caput Stenarum)}

5.1. Boița, fort and baths location.

5.2. Boița, site plan (Bogdan-Cătăniciu 1981, fig. 53).

5.3. Boița, oblique drone photograph, view from the west (November 2020).

5.4. Boița, oblique drone photograph, view from the south (November 2020).

5.5. Boiţa, drone orthophotoplan.

5.6. Boiţa, hillshade model.

5.7. Boița, site plan (Bogdan-Cătăniciu 1981, fig. 53) overlaid on the digital terrain model.

5.8. Boița, plan of geophysical surveys overlaid on the digital terrain model.

\section{Câineni. Râul Vadului}

6.1. Câineni. Râul Vadului, presumed location of the site.

6.2. Câineni. Râul Vadului, presumed location of the site, satelitte (Google Earth).

\section{Câineni. Câinenii Mici, Câinenii Mari (Pons Vetus)}

7.1. Câinenii Mici (left), Câinenii Mari (right), location of the plateau on which Arxavia fortification is located.

7.2. Câinenii Mici (left), Câinenii Mari (right), presumed location of site in the vicinity of former ford in area of the current bridge, oblique drone photograph, view from the west (November 2020).

7.3. Câineni, drone orthophotoplan.

7.4. Câineni, hillshade model.

\section{Racovița (,Praetorium II”?)}

8.1. Racovița, fort location (full polygon); presumed location of the Copăceni fort (empty polygon).

8.2. Racovița, fort plan (Tudor 1978, 289, fig. 80).

8.3. Racovița, orthophotoplan (September 2016).

8.4. Racovița, hillshade model.

8.5. Racovița, fort plan (Tudor 1978, 289, fig. 80) overlaid on the digital terrain model.

\section{Copăceni (,Praetorium I"?)}

9.1. Copăceni, fort plan (Gudea 1997, 93, nr. 81).

\section{Titești}

10.1. Titești, fort location

10.2. Titești, fort plan (reconstitution after Tudor 1978, 287, fig. 79/4).

10.3. Titești, oblique drone photograph, south-east view (November 2020).

10.4. Titești, oblique drone photograph, north view (November 2020). 
10.5. Titești, drone orthophotoplan.

10.6. Titești, fort's plan (reconstitution after Tudor 1978, 287, fig. 79/4) overlaid on the digital terrain model.

\section{Pripoare}

11.1. Pripoare, presumed location of the site.

11.2. Pripoare, oblique drone photograph, south view (November 2020).

11.3. Pripoare, oblique drone photograph, north-west view (November 2020).

11.4. Pripoare, drone orthophotoplan.

11.5. Pripoare, digital terrain model.

\section{Rădăcinești}

12.1. Rădăcinești, fort and baths location.

12.2. Rădăcinești, site plan (Bogdan-Cătăniciu 1997, fig. 42).

12.3. Rădăcinești, oblique drone photograph, south-west view (October 2020).

12.4. Rădăcinești, site plan (Bogdan-Cătăniciu 1997, fig. 42) overlaid on an oblique drone photograph, view from the south-west (October 2020).

12.5. Rădăcineşti, drone orthophotoplan.

12.6. Rădăcinești, hillshade model.

12.7. Rădăcinești, fort plan (after Bogdan-Cătăniciu 1997, fig. 42) overlaid on the digital terrain model.

\section{Văratica}

13.1. Presumed location of Văratica roman tower.

\section{Călimănești (Arutela)}

14.1. Călimănești (Arutela), Arutela site and tower on the Theophilus's Peak.

14.2. Călimănești (Arutela), site plan: a. Gr. Tocilescu (Tudor 1942, 144, fig. 1); b. (Poenaru-Bordea și Vlădescu 1974, 248, fig. 2).

14.3. Călimănești (Arutela), plan of Arutela baths by Gr. Tocilescu (Tudor 1942, 146, fig. 3).

14.4. Călimănești (Arutela): a. "Trajan's Table" (Tudor 1978, 51, fig. 3); b. view towards "Trajan's Table" and the old railway. View from the south-east (illustrated, 1909 - similar view https://www.europeana.eu/en/item/2058616/ omeka_items_show_1738).

14.5. Călimănești (Arutela), fort location: a. declassified 1968 Corona satellite photograph (1104-2155Aft; Aug 17 1968_Center for Advanced Spatial Technologies, University of Arkansas/U.S. Geological Survey); b. location of the fort on Military topographic map 1970-1980; c. location of the fort on orthophotoplan. (Google Earth 2021); d. digital terrain model overlaid on Google Earth Satellite Image 2021.

14.6. Călimănești (Arutela), oblique aerial photograph, view from the south-east (5 July 2010).

14.7. Călimăneşti (Arutela), drone orthophotoplan.

14.8. Călimănești (Arutela), site plans (Poenaru-Bordea și Vlădescu 1974, 248, fig. 2) overlaid on the digital terrain model.

14.9. Călimănești (Arutela), course of Olt river in the years 1968 and 2021 in the area of current Turnu dam overlay on Google Earth Satellite Image 2021.

14.10. Călimănești (Arutela), course of Olt river in the years 1968 and 2021 in the area of current Turnu dam, QGIS support.

\section{Jiblea}

15.1. Jiblea, presumed fort location.

15.2. Jiblea, oblique drone photograph, view from the southeast (November 2020).

15.3. Jiblea, hillshade model.

15.4. Jiblea, digital terrain model. 


\section{Sânbotin (Castra Traiana)}

16.1. Sânbotin (Castra Traiana), fort location.

16.2. Sânbotin (Castra Traiana), plan of the archaeological excavations (Tudor et al. 1970, 246, fig. 1).

16.3. Sânbotin (Castra Traiana), eastern enclosure plan (Bogdan-Cătăniciu 1997, fig. 35).

16.4. Sânbotin (Castra Traiana), oblique drone photograph, view from the west (November 2020).

16.5. Sânbotin (Castra Traiana), oblique drone photograph, view from the southeast (November 2020).

16.6. Sânbotin (Castra Traiana), drone orthophotoplan.

16.7. Sânbotin (Castra Traiana), hillshade model.

16.8. Sânbotin (Castra Traiana), eastern enclosure plan(Bogdan-Cătăniciu 1997, fig. 35) overlaid on the digital terrain model.

\section{Stolniceni (Buridava)}

17.1. Stolniceni (Buridava), site location.

17.2. Stolniceni (Buridava), site location, declassified 1966 Corona satellite photograph (1036-2139 Fore; Aug 18, 1966_Center for Advanced Spatial Technologies, University of Arkansas/U.S. Geological Survey).

17.3. Stolniceni (Buridava), plan of the presumed baths (Bichir et al. 1992, 257, fig. 1).

17.4. Stolniceni (Buridava), oblique drone photograph, view from the northwest (October 2020).

17.5. Stolniceni (Buridava), oblique drone photograph, view from the southeast (October 2020).

17.6. Stolniceni (Buridava), drone orthophotoplan.

17.7. Stolniceni (Buridava), hillshade model

17.8. Stolniceni (Buridava), baths plan (Bichir et al. 1992, 257, fig. 1) overlaid on the digital terrain model.

\section{Ionești}

18.1. Ionești, presumed site location.

18.2. Ionești, site plan (Gudea 1997, 88, nr. 73).

\section{Drăgășani}

19.1. Drăgășani, presumed site location.

19.2. Drăgășani, presumed site location (Tudor 1978, 316, fig. 92/4).

\section{Enoșești}

20.1. Enoșești, site location.

20.2. Enoșești, site plan (Tudor 1978, 258, fig. 79/3) overlaid on Google Earth (orthophotoplan).

\section{Reșca (Romula)}

21.1. Reșca (Romula), site location.

21.2. Reșca (Romula), plan of Romula forts (Marsigli 1726, apud. Tudor 1978, fig. 41.2).

21.3. Reșca (Romula), plan of Romula forts (Tudor 1978, 179, fig. 2).

21.4. Reșca (Romula), oblique aerial photograph, view from the east (July 2010).

21.5 Reșca (Romula), digital terrain model.

21.6. Reșca (Romula), general plan of the archaeological investigations since 2011, 2013 and 2015 (după Negru, Schuster 2016, 95 pl. I) overlaid on drone orthophotoplan (2017).

21.7. Reșca (Romula), roman roads, mounds, forts and enclosure of the ancient city of Romula overlaid on a declassified 1968 Corona satellite photograph (1104-2155 Aft; Aug 17, 1968_Center for Advanced Spatial Technologies, University of Arkansas/U.S. Geological Survey).

21.8. Reșca (Romula), Roman roads, mounds, forts and enclosure of the ancient city of Romula (Tudor 1978, 179, fig. 2) overlaid on Google Earth (orthophotoplan - 2021). 


\section{Slăveni}

22.1. Slăveni, site and baths location.

22.2. Slăveni, site location, declassified 1965 Corona satellite photograph (1026-2088 Aft; Nov 03, 1965_Center for Advanced Spatial Technologies, University of Arkansas/U.S. Geological Survey).

22.3. Slăveni, fort plan (Tudor et al. 2011, 143, fig. 88).

22.4. Slăveni, fort and baths plan (Tudor et al. 2011, 143, fig. 88) overlaid on Google Earth (orthophotoplan).

22.5. Slăveni, oblique aerial photograph, view from the west (July 2010).

\section{Tia Mare}

23.1. Tia Mare, site location.

23.2. Tia Mare, site location, declassified 1968 Corona satellite photograph (1103-1058 Fore; May 05, 1968 Center for Advanced Spatial Technologies, University of Arkansas/U.S. Geological Survey).

23.3. Tia Mare, oblique aerial photograph, view from the north-west (July 2010).

23.4. Tia Mare, oblique aerial photograph, view from the north-east (July 2010).

\section{Islaz}

24.1. Islaz, Islaz forts (Tudor 1978, 266, fig. 68/3).

24.2. Islaz, Islaz forts, declassified Corona satellite photograph 1968 (1103-1058 Fore; May 05, 1968_Center for Advanced Spatial Technologies, University of Arkansas/U.S. Geological Survey).

24.3. Islaz, Islaz forts Racovița (A) and Islaz Vedea (B) (Tudor 1978, 278, fig. 75/1-2).

24.4. Islaz, Islaz-Racovița, site location (A).

24.5. Islaz, Islaz-Vedea, site location (B).

24.6. Islaz, Islaz-Ostrovu, site location (C).

\section{Plates}

Pl. I. Map of roman provinces of Dacia, Moesia Superior, Moesia Inferior.

Pl. II. Roman fortifications in the mid Olt area: a. after Tudor 1981, 78, fig. 1.; b. QGIS support.

* The aerial photographs from 2010 were taken by Ioana A. Oltean and W. S. Hanson (STRATEG project). The drone photos were taken by Daniel Costea (PN LIMES).

OVIDIU TTENTEA

Muzeul Național de Istorie a României ovidiu.tentea@gmail.com

FLORIAN MATEI-POPESCU

Institutul de Arheologie „Vasile Pârvan” florian.matei@gmail.com

VLAD CĂLINA

Muzeul Național de Istorie a României calina.nicolae@gmail.com 